\title{
Plant-specific glutaredoxin ROXY9 regulates hyponastic growth by inhibiting TGA1 function
}

\author{
Dissertation \\ for the award of the degree \\ "Doctor of Philosophy" (Ph.D.) \\ Division of Mathematics and Natural Sciences \\ of the Georg-August-Universität Göttingen
}

within the doctoral program Biology

of the Georg-August University School of Science (GAUSS)

Submitted by

Ning Li

from Shandong, China

Göttingen 2017 


\section{Thesis Committee}

Prof. Dr. Christiane Gatz

(Department of Plant Molecular Biology and Physiology)

Prof. Dr. Volker Lipka

(Department of Plant Cell Biology)

Dr. Corinna Thurow

(Department of Plant Molecular Biology and Physiology)

\section{Members of the Examination Board}

Reviewer: $\quad$ Prof. Dr. Christiane Gatz

(Department of Plant Molecular Biology and Physiology)

Second reviewer: Prof. Dr. Volker Lipka

(Department of Plant Cell Biology)

Further members of the Examination Board:

Prof. Dr. Ivo Feussner

(Department of Plant Biochemistry)

PD Dr. Thomas Teichmann

(Department of Plant Cell Biology)

Dr. Marcel Wiermer

(Department of Plant Cell Biology)

PD. Dr. Martin Fulda

(Department of Plant Biochemistry)

Date of the oral examination: $\quad 30.03 .2017$ 



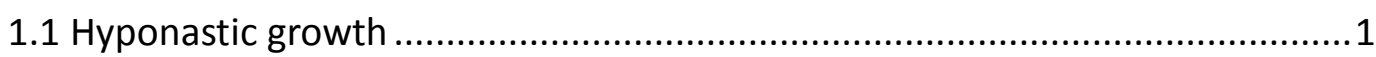

1.1.1 Ethylene and hyponastic growth in Arabidopsis thaliana .....................2

1.1.2 Photoreceptors and hyponastic growth ........................................... 3

1.1.3 Auxin and other plant hormones and hyponastic growth .................... 4

1.1.4 Transcription factors and hyponastic growth ....................................

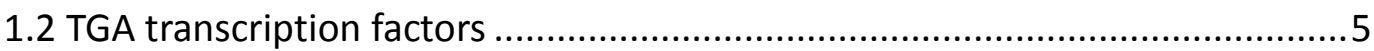

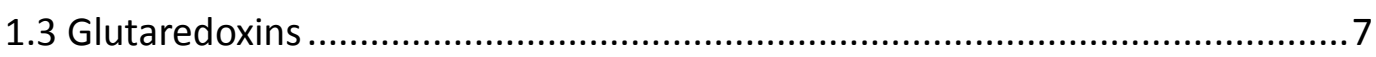

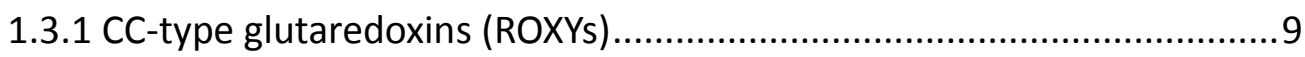

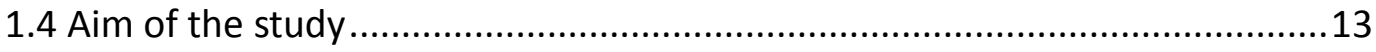

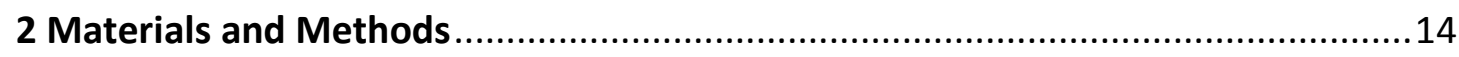

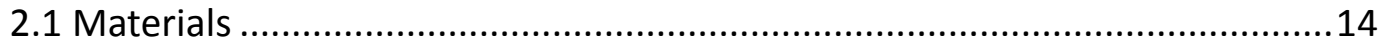

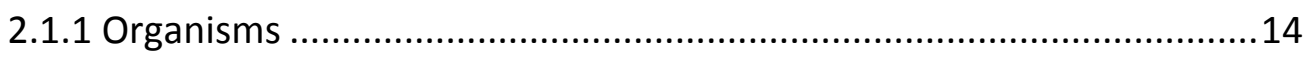

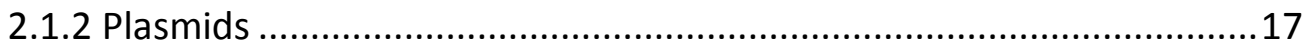

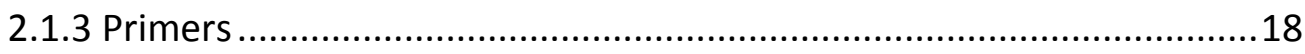

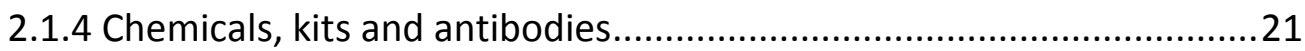

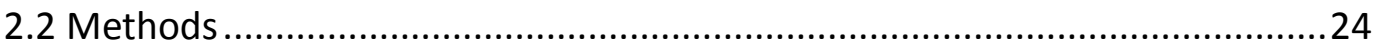

2.2.1 Plant growth and treatments......................................................24

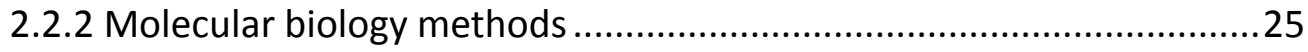

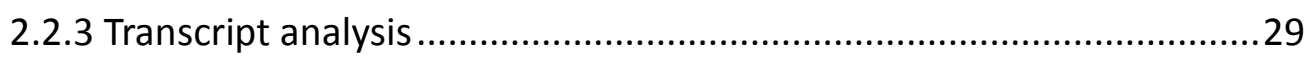

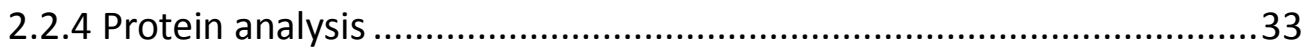

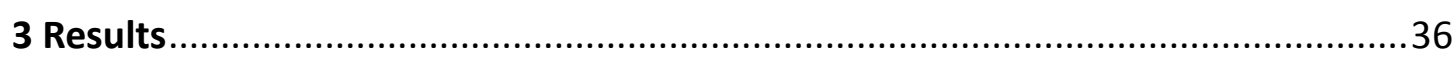

3.1 The tga1 tga4 mutant shows reduced hyponastic growth ............................36

3.2 Low light-induced hyponastic growth partially acts through the ethylene and

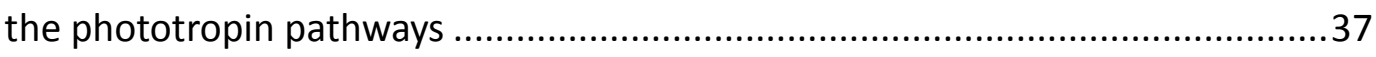

3.3 Redox-active cysteines of TGA1 are not important for the regulation of

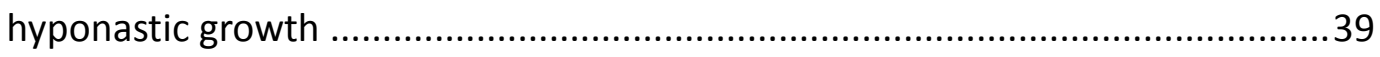

3.4 Redox-active cysteines of TGA1 are not important for salicylic acid-mediated inhibition of hyponastic growth

3.5 NPR1 and the redundant TGA factors TGA2, TGA5 and TGA6 are required for 
SA-mediated inhibition of hyponastic growth

3.6 The redox state of TGA1/TGA4 is not important for the reversal of hyponastic growth after transferring low light-treated plants back to control light intensities

3.7 The expression pattern of CC-type glutaredoxins ROXY8 and ROXY9 is consistent with their potential role as repressors of TGA1 and TGA4.....

3.8 Overexpression of ROXY 8 or ROXY9 phenocopies the tga1 tga 4 phenotype 46

3.9 The sequence of the C-terminal end of ROXY9 is not important for its repressive effect on hyponastic growth.

3.10 The sequence of CCLC motif in the active center of ROXY9 is important for its repressive effect on hyponastic growth

3.11 The roxy9 CRISPR-Cas9 mutant is not impaired in hyponastic growth. 51

3.12 The expression of over 150 low-light-induced genes correlates with hyponastic growth in wild-type, tga1 tga4 and 35S:ROXY19 plants .52

3.13 Petioles of tga1 tga4 and 35S:HA-ROXY9 plants are shorter than wild-type petioles

3.14 Genes with putative oxidoreductase activities are more highly expressed in tga1 tga4 and 35S:HA-ROXY9 plants than in wild-type. 58

3.15 Motif mapper analysis suggests that TGA1 and TGA4 are negative regulators of gene expression 62

4 Discussion 64

4.1 TGA1 and TGA4 are connected to various signaling cascades that induce hyponastic growth 64

4.2 The CC-motif is important for the repressive activity of ROXY9 67

4.3 Low light-induced expression of genes potentially involved in hyponastic growth are less expressed in tga1 tga4 and 35S:HA-ROXY9 plants. 68

5 Conclusion 70

6 Summary 71

7 References 72

8 Abbreviations 83 
9 Supplementary data

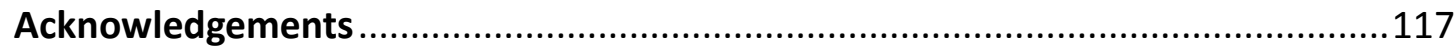

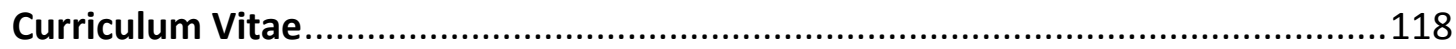




\section{Introduction}

\subsection{Hyponastic growth}

Being confined to a fixed location, plants have to re-orient their growth directions when it comes to getting access to limiting resources like light or water. Hyponasty, also called hyponastic growth, puts leaves and petioles into a more vertical position to escape from unfavorable conditions, such as submergence (Cox et al., 2003; Pierik et al., 2005), root waterlogging (Rauf et al., 2013), decreased light intensities (Vandenbussche et al., 2003; Pierik et al., 2005), increased far-red (FR) to red light (R) ratios (Whitelam and Johnson, et al., 1982; Vandenbussche et al., 2003; Pierik et al., 2005; Millenaar et al., 2009), and elevated temperatures (Koini et al., 2009; van Zanten et al., 2009). Upward bending of the leaves is due to differential growth rates between the adaxial and the abaxial sides of the petioles (Kang et al., 1979; Polko et al., 2012b; Cox et al., 2004). This requires the reorientation of cortical microtubules (Polko et al., 2012b) and expression of cell wall-loosening enzymes like e.g expansins (Vreeburg et al., 2005, Rauf et al., 2013) and members of the XYLOGLUCAN ENDOTRANSGLYCOSYLASE/HYDROLASE (XTH) gene family (Lee et al., 2011). It is hypothesized that hyponastic growth is induced by an asymmetrical distribution of growth-regulating factors. Candidates are ethylene (ET) and auxin or an increased sensitivity of the abaxial site to growth promoting cues. The significance of asymmetrical distribution of auxin in tropic responses is well established (Went and Thimann, et al., 1937; Friml and Palme, et al., 2002), but the contribution of such a mechanism in nastic responses seems unlikely (Cox et al., 2003). ET can play a role in differential growth processes like petiole epinasty (Kang et al., 1979), shoot gravitropism (Kaufman et al., 1995; Friedman et al., 2003), apical hook formation (Ecker et al., 1995), but the molecular mechanisms leading to differential ET production/sensitivity during hyponasic growth are unknown. 


\subsubsection{Ethylene and hyponastic growth in Arabidopsis thaliana}

Application of ET triggers hyponastic growth in the several ecotypes of Arabidopsis, including Columbia, but not in Landsberg (Millenaar et al., 2005). Thus, a plausible hypothesis was that environmental cues would lead to the synthesis or accumulation of ET as a common signaling molecule. This concept is well established for Arabidopsis plants subjected to root waterlogging (Rauf et al., 2013) or complete submergence (Millenaar et al., 2005). However, ET is a negative regulator of hyponastic growth at high temperature (van Zanten et al., 2009). Conflicting data are available concerning the role of ET in the hyponastic growth of plants subjected to low light intensities. Vandenbussche et al. (2003) found that two-week-old Arabidopsis seedlings, which were grown on the ET precursor 1-aminocyclopropane-1-carboxylic acid (ACC), produced ET upon transfer to low light conditions $\left(35 \mu \mathrm{mol}\right.$ photons $\left.\mathrm{m}^{-2} \mathrm{~s}^{-1}\right)$. Mutants deficient in ET signal transduction (ein2, etr1-3) showed no increased leaf angle when continuously grown under 45 $\mu \mathrm{mol}$ photons $\mathrm{m}^{-2} \mathrm{~s}^{-1}$ as opposed to $125 \mu \mathrm{mol}$ photons $\mathrm{m}^{-2} \mathrm{~s}^{-1}$. In contrast, Millenaar et al. (2009) found that ein2, etr1-4 and ein 4 plants responded like wild-type when plants were transferred from 200 to $20 \mu \mathrm{mol}$ photons $\mathrm{m}^{-2} \mathrm{~s}^{-1}$ for 0 to 24 hours. No increase in ET production was observed. These studies indicate that growth conditions, ecotype and developmental stage of the plant might influence the underlying signaling cascades.

Moreover, Polko et al. (2015) found that overexpression of the mitotic cyclin CYCLINA2;1(CYCA2;1) shows exaggerated hyponasty, indicating a role for cell divisions in regulating hyponastic growth. According to experimental results and mathematical modeling, it was assumed that ET can attenuate the amplitude of hyponasty by decreasing the cell proliferation rate at the proximal abaxial side of the petiole relative to the adaxial side (Polko et al., 2015). 


\subsubsection{Photoreceptors and hyponastic growth}

A similar complex picture arises with respect to the involvement of photoreceptors in hyponastic growth. Hyponastic growth is a part of the shade avoidance syndrome (Franklin et al., 2008), which is efficiently induced when the ratio of red (R) to far red (FR) light is reduced (Whitelam \& Johnson et al., 1982). Elongation of petioles, hyponastic growth and reduction of leaf blade area occur when the amount of $R$ is reduced due to the absorption of $\mathrm{R}$ but not FR by chlorophyll from shading plants or when the amount of FR is enriched due to the reflection by neighboring plants. These conditions are perceived by phytochromes $A$ and $B$, which are activated by FR or R, respectively (reviewed in Franklin et al., 2008; Ballaré, et al., 2009; Keuskampet et al., 2010a). Under control light conditions, the R photoreceptor PhyB interferes with hyponastic growth as revealed by the constitutively high petiole angles in the phyB-5 mutant (Millenaar et al., 2009). Under low R/FR, most of PhyB is in the inactive Pr form allowing the shade avoidance response (Robson et al., 1993). If light intensities are high but R/FR ratios low, PhyA is activated by FR and represses the shade avoidance response. This antagonistic interaction of both photoreceptors allows adjusting growth to the R/FR ratios and the light intensities at the same time. Hyponastic growth initiated by decreased R/FR ratios does not involve the ET pathway (Vandenbussche et al., 2003)

Different mechanisms have to be considered when decreased light intensities serve as the signal for hyponastic growth. Decreasing the light intensity but adding R did not reduce hyponastic growth at $6 \mathrm{~h}, 24 \mathrm{~h}$ and $48 \mathrm{~h}$. Thus, PhyB is not able to repress hyponastic growth under low light conditions. However, addition of blue light interfered with hyponastic growth at least at 6 hours. Apparently, blue-light-activated photoreceptors can interfere with hyponastic growth under low light. Candidates are PhyA, which can be activated by blue light, cryptochromes and phototropins (Millenaar et al., 2009). 
The phot 1 phot 2 mutant behaved like wild-type when plants were shifted from control light to low light. However, photoreceptors PhyA and cryptochromes Cry1 and Cry2 were required for hyponastic growth (Millenaar et al., 2009). Taken together, it seems that hyponastic growth can be inhibited if photoreceptors are activated by either R or B, but that residual activation is important to sustain hyponastic growth. The control of hyponastic growth by photoreceptors plays a role only during the first 6 hours. When plants are subjected to low light for longer periods other signals resulting from reduced photosynthesis control the response (Millenaar et al., 2009).

\subsubsection{Auxin and other plant hormones and hyponastic growth}

As mentioned above, upward bending of the leaves is due to differential growth rates between the adaxial and the abaxial sides of the petioles (Cox et al., 2004; Polko et al., 2012b; Polko et al., 2015). As already described early in the last century, the phytohormone auxin is transported through the plant in a polar manner and is essential for differential growth (Went and Thimann et al., 1937). Auxin acts through the activation of cell wall-loosening enzymes, allowing water uptake and cell expansion (Ordin et al., 1956; Taiz et al., 1984; Catalá et al., 2000). The direction of cell expansion is determined by cortical microtubules that are reoriented during this process (Polko et al., 2012b). Several studies have shown that inhibition of polar auxin transport or mutants in auxin signaling show impaired hyponastic growth in response to low light (Millenaar et al., 2009). However, the defect was mainly observed after 12 hours indicating the hormone is required for maintenance of the elevated leaf angle and that other growth promoting factors have to act early. Auxin does not play a role when hyponasty is triggered by ET (van Zanten et al., 2009).

Abscisic acid (ABA) antagonizes ET-induced hyponastic growth (Benschop et al., 2007). Like-wise, methyl jasmonate (MeJA) is a negative regulator of low light-induced hyponastic growth (Ritsema et al., 2010); in contrast, it promotes 
ET-induced hyponasty (van Zanten et al., 2012). SA suppresses both ET and low light-induced hyponasty (Ritsema et al., 2010; van Zanten et al., 2012).

\subsubsection{Transcription factors and hyponastic growth}

A few transcription factors have been involved in hyponastic growth. Hyponasty in response to root waterlogging is regulated by NAC (NAM, ATAF1/2, CUC2) transcription factor SPEEDY HYPONASTIC GROWTH (SHYG) in Arabidopsis thaliana. Ectopic expression of SHYG in Arabidopsis enhances waterlogging-triggered hyponastic leaf movement, while shyg knockout mutants show reduced hyponastic leaf movement. Several genes related to cell wall-loosening like EXPANSINs and XYLOGLUCAN ENDOTRANSGLYCOSYLASE/HYDROLASES are up-regulated in SHYG overexpressing lines and down-regulated in shyg mutants. Moreover, ACC OXIDASE5 (ACO5), which encodes for a key enzyme of ET biosynthesis, is a direct target gene of SHYG (Rauf et al., 2013).

Phytochrome Interacting Factor 4 is a basic-loop-helix (bHLH)-type transcription factor that is required for hyponastic growth at elevated temperatures. This transcription factor is stabilized when active phytochrome levels are reduced under low light or reduced R/FR ratios. However, at least PIF4-dependent hypocotyls length can be stimulated in plants lacking phytochromes, pointing at a mechanism of heat sensing that involves other molecular components (Koini et al., 2009).

\subsection{TGA transcription factors}

TGA transcription factors belong to the basic region/leucine zipper motif (bZIP) transcription factor (TF) superfamily (Jakoby et al., 2002). TGA factors can specifically recognize the DNA sequence TGACGTCA and were named according to the first three letters of the sequence (Katagiri et al., 1989; Lam et al., 1989). The ten genes of the 
TGA family fall into five clades (Clade I: TGA1 and TGA4, clade II: TGA2, TGA5 and TGA6, clade III: TGA3 and TGA7, clade IV: TGA9 and TGA10, clade V: TGA8 (PAN)). The first three clades are mainly related to pathogen defense processes (Zhang et al., 2003; Kesarwani et al., 2007) and the other two clades are mainly related to flower development (Running et al., 1996; Murmu et al., 2010).

Clade II TGA TFs (TGA2, TGA5, TGA6) regulate the plant defense response systemic acquired resistance (Zhang et al., 2003) and the expression of detoxification genes (Fode et al., 2008; Mueller et al., 2008). Clade II TGA TFs directly interact with NONEXPRESSOR OF PR GENES 1 (NPR1) (Zhang et al., 1999) and the tga 2 tga5 tga6 triple mutant plants show a similar phenotype like the npr1-1 mutant in terms of pathogenesis-related 1 (PR1) expression and systemic acquired resistance (Zhang et al., 2003). Activation of detoxification genes, which is independent of NPR1, requires the interaction between clade II TGA TFs and the GRAS protein SCL14. scl14 and tga2 tga5 tga6 mutants show susceptibility to the SA structural analog 2,6-dichloroisonicotinic acid (INA) or to 2,4,6-triiodobenzoic acid (TIBA) (Fode et al., 2008).

Clade I TGA transcription factors (TGA1, TGA4) are involved in defense responses against biotrophic pathogens (Kersawani et al., 2007, Shearer et al., 2012). They have two conserved cysteines (Cys-260 and Cys-266) which can form an intramolecular disulfide bridge (Despres et al., 2003). In the absence of SA, 50\% of the TGA1 protein is in the oxidized form and $50 \%$ is in the reduced form. After exogenous application of SA, only the reduced form exists. The interaction with NPR1 takes place in yeast and Arabidopsis after a change of the conserved cysteine residues into a serine and aspartic acid, respectively (Despres et al., 2003), which prevents formation of the disulfide bridge. It was concluded that reduction of the protein allows the interaction with NPR1. Besides forming an internal disulfide bridge, TGA1 is S-nitrosylated or glutathionylated in vitro after treatment with S-nitrosoglutathione, a physiological nitric oxide donor (Lindermayr et al., 2010). 
Still, the function of TGA1 is more likely independent of NPR1 as revealed by the triple mutant tga1 tga4 npr1-1, which is more susceptible to Pseudomonas syringae pv maculicola (Psm ES4326) than npr1-1 mutants and tga1 tga4 double mutants. Moreover, a number of defense genes that are positively regulated by NPR1 are negatively regulated by TGA1 and TGA4. However, the enhanced expression of these genes in the tga1 tga4 double mutant does not fit to the observed higher susceptibility of the mutant (Shearer et al., 2012). Further studies found that apoplastic defense responses such as oxidative burst and callose deposition after treatment of plants with Pathogen Asscociated Molecular Patterns (PAMPs) are reduced in the tga1 tga4 double mutant plants. Total and apoplastic PR1 protein accumulation was reduced in in tga1 tga4 double mutant as well. Moreover, tga1 tga4 plants showed increased sensitivity to tunicamycin, an inhibitor of $\mathrm{N}$-linked glycosylation that can trigger ER stress, suggesting that the reduced defense responses are associated with aberrant protein secretion. It was concluded that clade I TGA factors act as positive regulators of ER-related secretion pathways (Wang et al., 2013).

\subsection{Glutaredoxins}

Glutaredoxins (GRXs) are small, ubiquitous oxidoreductases that are important for the regulation of the redox status of target proteins by using glutathione (GSH) as a cofactor. All GRXs contain a conserved active site ( $\mathrm{CxxC} / \mathrm{S})$ and a GSH binding site (Lillig et al., 2008). Based on the active site, GRXs are divided into three classes (Lemaire et al., 2004). Class I dithiol CxxC type (usually CPYC) and class II monothiol CGFS type are common to all prokaryotes and eukaryotes. Class III CCMC/S type GRXs (also called ROXYs) are only found in the genomes of land plants (Lemaire et al., 2004). For the monothiol mechanism, the CGFS-type GRXs reduce glutathionylated proteins by forming an GRX-GSH complex. The complex is further reduced by a GSH. 
For the dithiol mechanism, the CxxC-type GRX reacts with a disulfide bridge of a target protein, resulting in a GRX-protein-mixed disulfide complex. The complex is further reduced by the second resolving cysteine of the active site, yielding a reduced target protein and an oxidized GRX. Subsequently, the oxidized GRX is reduced by GSH, resulting in a reduced GRX and an oxidized GSH. The oxidized GSH can be reduced by glutathione reductase in the presence of NADPH (Fernandes and Holmgren et al., 2004).

It is known that GRXs are involved in assembly of iron sulfur [Fe-S] clusters as well. [Fe-S] clusters are important for fundamental life processes such as electron transfer, substrate binding/activation, enzyme activity, iron-sulfur storage, and regulation of gene expression (Glaser et al., 2000; Johnson et al., 2005). Iron-sulfur [Fe-S] clusters are common in all prokaryotes and eukaryotes, including bacteria, plants and animals. There are more than 120 different types of enzymes and proteins known to contain [Fe-S] clusters.

In Arabidopsis, AtGrxC5, a class I glutaredoxin possessing a WCSYC active site, incorporates a [2Fe-2S] cluster when it is in its dimeric holoprotein conformation. Here, the second active site cysteine (Cys32) is required for cluster binding (Couturier et al., 2011). Plant chloroplast class II CGFS-type glutaredoxins, GrxS14 and GrxS16, are able to complement a yeast grx 5 mutant defective in [Fe-S] cluster assembly and GrxS14 can transfer [2Fe-2S] clusters to apo ferredoxin in vitro (Bandyopadhyay et al., 2008).

In yeast, GRX-3 (class II, CGFS) and the BolA-like protein Fe repressor of activation-2 can form a [2Fe-2S]-bridged heterodimer. The heterodimer can transfer [Fe-S] clusters (or $\mathrm{Fe}^{2+}$ ) to $\mathrm{Aft} 2$ (activators of ferrous transport) that facilitates Aft2 dimerization, which leads to decrease the DNA-binding affinity and down-regulation of the expression of iron-uptake genes (Poor et al., 2014). 


\subsubsection{CC-type glutaredoxins (ROXYs)}

The land plant-specific CC-type GRXs (named ROXYs in Arabidopsis) are characterized by carrying a conserved CC motif in their active site. The biochemical activities of these proteins are poorly understood. Couturier et al. (2010) reported that the in vitro purified poplar class III glutaredoxin protein GrXS7.2 possesses two absorption bands at 322 and $415 \mathrm{~nm}$ in the UV/Visible spectrum which is a typical feature of proteins incorporating an [Fe-S] cluster. Yet, the oxidoreductase activity of GrxS7.2 was very weak as compared to the other two class I GRXs, GrxC1 and GrxC4.

The Arabidopsis thaliana genome encodes 21 ROXY gens. Besides the conserved CC motif, these proteins contain a $L^{* *} L L$ motif and the ALWL motif at the C-terminal end (Figure 2.1). CC-type GRXs can interact with TGA TFs physically and genetically. In Arabidopsis, the best studied ROXYs are ROXY1, ROXY2, ROXY18 and ROXY19 (Gutsche et al., 2015).

The mutant roxy 1 was isolated on the basis of aberrant petals with reduced number and abnormal shape. In contrast to wild-type Arabidopsis, which has four petals with almost equal size, the petal number of the roxy 1 mutant varies between 0 and 4 with an average of 2.5 (Xing et al., 2005). TGA transcription factors (TGA2, TGA3, TGA7, PAN) were identified as proteins interacting with ROXY1 by yeast two-hybrid screening (Li et al., 2009). Since the petal number of pan (PAN is a clade IV TGA transcription factor) is five, it was hypothesized that PAN and ROXY1 interact genetically. Indeed, the roxy1 pan double mutant has five petals. This indicates that ROXY1 represses the function of PAN. Furthermore, the residue Cys340 in PAN is important for the phenotype as concluded from the observation that PAN encoding the point mutation C340S cannot complement the phenotype. Therefore, it was speculated that PAN activity is regulated through a redox modification at C340 which is catalyzed by ROXY1. However, experimental evidence for such a mechanism is still 


\begin{tabular}{|c|c|c|c|}
\hline & & $\begin{array}{l}\text { active } \\
\text { center }\end{array}$ & $\begin{array}{l}\mathrm{L}^{\star} \star \mathrm{LL} \\
\text { motif }\end{array}$ \\
\hline ROXY1 & At $3 g 02000$ & $\mathrm{CCMC}$ & VMASH INGS LVPLLKDAGALWL \\
\hline ROXY2 & At $5 g 14070$ & $\mathrm{CCMC}$ & VMASH INGS LVPLLKDAGALWL \\
\hline ROXY3 & At $3 g 21460$ & CCMS & VMTLHLNGS LKILLKEAGALWL \\
\hline ROXY 4 & At $3 g 62950$ & $\mathrm{CCMC}$ & I ISFHVDGS LKQMLKDAKA IWL \\
\hline ROXY 5 & At $2 g 47870$ & $\mathrm{CCMC}$ & VISFHVDGS LKQMLKASNA IWL \\
\hline ROXY10 & At $5 g 18600$ & CCMS & VMSLHLNGS LI PMLKRAGALWV \\
\hline ROXY11 & At $4 g 15700$ & $\mathrm{CCMS}$ & VMSLHLNRS LVPMLKRAGALWL \\
\hline ROXY12 & At $4 g 15690$ & CCMS & VMSLHLNRS LVPMLKRAGALWL \\
\hline ROXY13 & At $4 g 15680$ & CCMS & VMSLHLNRS LVPMLKRVGALWL \\
\hline ROXY14 & At 4g15670 & CCMS & VMSLHLNRS LIPMLKRVGALWL \\
\hline ROXY15 & At $4 g 15660$ & CCMS & VMSLHLNRS LIPMLKRFGALWL \\
\hline ROXY17 & At $3 g 62930$ & CCMS & VMTLQVKNQLAAMLRRAGA IWV \\
\hline ROXY18 & At $\lg 03850$ & CCLG & LMAAH INGDLVPTLRQAGALWL \\
\hline ROXY19 & At $1 g 28480$ & $\mathrm{CCMC}$ & VMATHISGELVPILKEVGALWL \\
\hline ROXY21 & At $4 g 33040$ & $\mathrm{CCMC}$ & LVALHLSGQLVPKLVQVGALWV \\
\hline ROXY 6 & At1g06830 & CCLC & VMSMHLSSSLVPLVKPY---LC \\
\hline ROXY 7 & At2g30540 & CCMS & VMSLHLSGSLVPLVKPFQANLC \\
\hline ROXY 8 & At $3 g 62960$ & CCLC & VMSLHLSGSLVPLIKPYQSFHN \\
\hline ROXY 9 & At $2 g 47880$ & CCLC & VMSLHLSGSLVPLIKPYQS ILY \\
\hline ROXY16 & At1g03020 & CCMS & LMSLQVRNQLASLLRRAGA IWI \\
\hline ROXY20 & At $5 g 11930$ & $\mathrm{CCMC}$ & LVALHLSGQLIPRLVEVGALWA \\
\hline
\end{tabular}

Figure 2.1: Alignment of the C-terminal sequences of CC-type glutaredoxins (Zander et al., 2012).

The $L^{* *} \mathrm{LL}$ motif is shown in bold letters with the critical leucine residues in blue. The C-terminal ALWL motif is shown in red.

missing. The single mutant of the closest homolog of ROXY1, roxy2, does not cause any obvious phenotype but the roxy 1 roxy 2 double mutant was did not produce pollen, similar to the tga9 tga10 double mutant (Xing et al., 2008; Murmu et al., 2010). Since ROXY1 and ROXY2 can interact with TGA9 and TGA10 (Murmu et al., 2010), it was concluded that ROXY1 and ROXY2 regulate anther development by regulating the activity of TGA9 and TGA10. 
ROXY19 (GRX480) was isolated as a TGA2-interacting protein through a modified yeast one-hybrid screening. The expression of ROXY19 is induced by SA and requires TGA factors and NPR1 (Ndamukong et al., 2007). Ectopic expression of ROXY19 represses the activation of the jasmonic acid/ET (JA/ET) defense pathway. It acts very early in this singalling cascade by repressing the promoter of the ORA59 gene. ORA59 is a regulator of JA/ET-inducible defense genes, including plant defensin gene PDF1.2. Consistently, plants ectopically expressing ROXY19 are more susceptible to necrotrophic pathogens (Lai et al., 2014). ROXY19-mediated suppression of gene expression depends on clade II TGA TFs. Since SA represses the JA/ET pathway in a TGA2/5/6-dependent manner, it was postulated that SA-induced ROXY19 mediates the SA-imposed antagonism over the JA/ET pathway (Ndamukong et al., 2007; Zander et al., 2012). However, this hypothesis was not yet confirmed in the roxy19 mutant. Moreover, ectopically expressed ROXY19 represses detoxification genes which depend on clade II TGA factors (Huang, et al., 2016).

ROXY18, the closest homolog of ROXY19, was studied by La Camera et al. (2011). The roxy18 mutant plants are less susceptible to $B$. cinerea as compared to wild-type plants and constitutive expression of ROXY18 leads to an increased susceptibility to $B$. cinerea, indicating a negative role in regulating defense responses against $B$. cinerea. However, the expression of classical TGA-dependent defense genes like PR1 and PDF1.2 are not influenced after infection of the mutant by $B$. cinerea. Therefore, the mechanism how ROXY18 enhances the susceptibility to $B$. cinerea has remained unknown (La Camera et al., 2011).

The ALWL motif, which is present at the C-terminal end of many ROXYs, is required for the functions of ROXY1 and ROXY18: Complementation analysis of roxy1-2 mutant with other ROXYs under the control of ROXY1 native promoter revealed that only the ROXYs containing the ALWL motif are capable of rescuing the abnormal petal phenotype of the roxy1 mutant (Li et al., 2009). In addition, only ROXYs with the C-terminal ALWL motif suppress ORA59 promoter activity in Arabidopsis protoplasts 
(Zander et al., 2012). Recent analysis has shown that the transcriptional co-repressor TOPLESS binds to the ALWL motif (Uhrig et al., 2017). The repressive function of ALWL-containing ROXYs can therefore be explained by the recruitment of TOPLESS to TGA-regulated promoters.

The $L^{* *} L L$ motif at the C-terminal end of ROXY1 was found to be required for the interaction with PAN and TGA3 in yeast (Li et al., 2011). The interaction is disrupted by substitutions of any leucine in $\mathrm{L}^{* *} \mathrm{LL}$ to alanine. Consistently, transgenic plants expressing leucine-mutagenized ROXY1 proteins under the control of the ROXY1 native promoter fail to complement the abnormal petal development of the roxy1 mutant. Likewise, the repressive function of ROXY19 on the ORA59 promoter requires this motif (Zander et al., 2012). Whether this motif is required for directly contacting TGA factors or whether it is required for a correct tertiary structure of the protein has not been further investigated.

The CC-active center was found to be required for the biological function of some ectopically expressed ROXYs. For example, the roxy1 phenotype can be complemented by ectopic expression of ROXY1 under the control of the CaMV 355 promoter, whereas the mutation in the first cysteine (SCMC) of the active site leads to a protein that is unable to complement. In contrast, the mutation in the last cysteine (CCMS) restores the phenotype of over $50 \%$ of the T1 roxy1-3 mutants (Xing et al., 2005). In contrast, when expressed under the endogenous ROXY1 promoter, the protein was functional (Ziemann et al., 2010). Even mutating the active site into SSMS did not abolish its function. Thus, the importance of the active site for ROXY1 function is still controversial. ROXY19 containing a SSMS sequence in the active site was not functional in planta (Huang et al., 2016). 


\subsection{Aim of the study}

Since the transcription factors TGA1 and TGA4 have redox-active cysteines and since they interact with ROXYs, the question arose whether ROXYs are involved in the redox modification of TGA1 and TGA4. In the course of this thesis, it was discovered that the tga1 tga4 mutant shows compromised hyponastic growth. This observation led to the following questions.

- Which signaling cascades activate TGA1/TGA4-depenent hyponastic growth?

- Which genes are regulated by TGA1/TGA4 during hyponastic growth?

- Are the redox-active cysteines important for TGA1 to regulate hyponastic growth?

- Which ROXYs can regulate hyponastic growth and is the catalytic center important for their in vivo activities? 


\section{Materials and Methods}

\subsection{Materials}

\subsubsection{Organisms}

\subsubsection{Bacteria}

\begin{tabular}{|c|c|c|c|}
\hline strain & Description (Genotype) & Usage & Reference \\
\hline $\begin{array}{l}\text { Escherichia coli } \\
\text { DH5 } \alpha\end{array}$ & 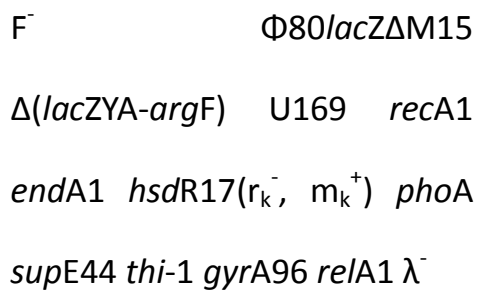 & $\begin{array}{l}\text { Plasmid } \\
\text { construction }\end{array}$ & $\begin{array}{l}\text { Thermo Fisher } \\
\text { Scientific }\end{array}$ \\
\hline $\begin{array}{l}\text { Escherichia coli } \\
\text { DB3.1 }\end{array}$ & $\begin{array}{l}\mathrm{F}-\text { gyrA462 endA1 } \Delta(\mathrm{sr} 1-r e c \mathrm{~A}) \\
\text { mcrB } m r r \text { hsdS20(rB-, mB-) } \\
\text { supE44 ara-14 ga/K2 lacY1 } \\
\text { proA2 rpsL20(SmR) xyl-5 } \lambda \text {-leu } \\
\text { mt/1 }\end{array}$ & $\begin{array}{l}\text { Plasmid } \\
\text { construction }\end{array}$ & $\begin{array}{l}\text { Thermo Fisher } \\
\text { Scientific }\end{array}$ \\
\hline $\begin{array}{l}\text { Agrobacterium } \\
\text { tumefaciens } \\
\text { GV3101 } \\
\text { (pMP90RK) }\end{array}$ & C58; Rif ${ }^{R} ;$ Gent $^{R}$ & $\begin{array}{l}\text { Plant } \\
\text { transformation }\end{array}$ & $\begin{array}{l}\text { (Koncz and } \\
\text { Schell, 1986) }\end{array}$ \\
\hline
\end{tabular}

\subsubsection{Plants}

\begin{tabular}{|l|l|l|}
\hline Genotype & Description & Reference \\
\hline Col-0 & Arabidopsis thaliana Columbia-0 (Col-0) & TAIR \\
\hline tga1 tga4 & $\begin{array}{l}\text { tga1 and tga4 double mutant in Col-0 } \\
\text { background }\end{array}$ & $\begin{array}{l}\text { Prof. Dr. Yuelin } \\
\text { et al., 2007) }\end{array}$ \\
\hline tga2 tga5 tga6 & tga2, tga5 and tga6 triple mutant in Col-0 & (Zhang et al., \\
\hline
\end{tabular}




\begin{tabular}{|c|c|c|}
\hline & background & 2003) \\
\hline$n p r 1-1$ & Knock out line lacking functional NPR1 & (Cao et al., 1994) \\
\hline ein2-1 & $\begin{array}{l}\text { a strong allele of ein } 2 \\
\text { generated by ethylmethane sulfonate } \\
\text { (EMS) mutagenesis }\end{array}$ & $\begin{array}{l}\text { (Roman et al., } \\
\text { 1995) }\end{array}$ \\
\hline phyB-9 & $\begin{array}{l}\text { a strong allele of phyB } \\
\text { generated by ethylmethane sulfonate } \\
\text { (EMS) mutagenesis }\end{array}$ & $\begin{array}{l}\text { Professor Dr. } \\
\text { Gregg A. Howe } \\
\text { (Campos et al., } \\
2006 \text { ) }\end{array}$ \\
\hline cry1 cry2 & $\begin{array}{l}\text { cry1 (hy4-B104) and cry2-1 double mutant } \\
\text { in col-0 background }\end{array}$ & $\begin{array}{l}\text { Professor Dr. } \\
\text { Alfred Batschauer } \\
\text { (Mockler et al., } \\
\text { 1999) }\end{array}$ \\
\hline phot1 phot2 & $\begin{array}{l}\text { phot } 1-5 \text { and phot } 2-1 \text { double mutant in col-0 } \\
\text { background }\end{array}$ & $\begin{array}{l}\text { Professor Dr. } \\
\text { Alfred Batschauer } \\
\text { (Lariguet et al., } \\
\text { 2006) }\end{array}$ \\
\hline shyg-1 & $\begin{array}{l}\text { homozygous T-DNA insertion line } \\
\text { SALK-066615 }\end{array}$ & $\begin{array}{l}\text { Prof. Dr. Bernd } \\
\text { Mueller-Roeber } \\
\text { (Rauf et al., 2013) }\end{array}$ \\
\hline shyg-2 & $\begin{array}{l}\text { homozygous T-DNA insertion line } \\
\text { GK-343D11 }\end{array}$ & $\begin{array}{l}\text { Prof. Dr. Bernd } \\
\text { Mueller-Roeber } \\
\text { (Rauf et al., 2013) }\end{array}$ \\
\hline 35S:SHYG & SHYG overexpression line in Col-0 & $\begin{array}{l}\text { Prof. Dr. Bernd } \\
\text { Mueller-Roeber } \\
\text { (Rauf et al., 2013) }\end{array}$ \\
\hline$H A-g T G A 1$ & $\begin{array}{l}\text { tga1 tga4 mutant complemented with } \\
\text { genomic TGA1 with } 1 \times \mathrm{HA} \text { fused to the } \\
\mathrm{N} \text {-terminus of TGA1 }\end{array}$ & $\begin{array}{l}\text { Prof. Dr. Yuelin } \\
\text { Zhang } \\
\text { (Shearer et al., }\end{array}$ \\
\hline
\end{tabular}




\begin{tabular}{|c|c|c|}
\hline & & 2012) \\
\hline HA-gTGA1cys & $\begin{array}{l}\text { tga1 tga4 mutant complemented with } \\
\text { genomic TGA1 conserved cysteine } \\
\text { (CNLKQSC) mutated to NNLKQSS with } 1 \times \mathrm{HA} \\
\text { fused to the N-terminus of TGA1 }\end{array}$ & $\begin{array}{l}\text { Prof. Dr. Yuelin } \\
\text { Zhang } \\
\text { The University of } \\
\text { British Columbia, } \\
\text { Vancouver }\end{array}$ \\
\hline 35S:HA-ROXY19 & $\begin{array}{l}\text { ROXY19 overexpression line in Col-0 with } \\
\text { 3XHA fused to the N-terminus of ROXY19 }\end{array}$ & $\begin{array}{l}\text { (Li-Jun Huang et } \\
\text { al., 2016) }\end{array}$ \\
\hline 35S:HA-ROXY9 & $\begin{array}{l}\text { ROXY9 overexpression line in Col-0 with } \\
\text { 3XHA fused to the N-terminus of ROXY9 }\end{array}$ & $\begin{array}{l}\text { Dr. Martin } \\
\text { Muthreich and } \\
\text { this work }\end{array}$ \\
\hline 35S:HA-ROXY9SCLC & $\begin{array}{l}\text { ROXY9 overexpression line with the active } \\
\text { site (CCLC) replaced by SCLC in Col- } 0 \text { with } \\
\text { 3xHA fused to the N-terminus of ROXY9 }\end{array}$ & This work \\
\hline 35S:HA-ROXY9CSLC & $\begin{array}{l}\text { ROXY9 overexpression line with the active } \\
\text { site (CCLC) replaced by CSLC in Col- } 0 \text { with } \\
\text { 3XHA fused to the N-terminus of ROXY9 }\end{array}$ & This work \\
\hline 35S:HA-ROXY9CCLS & $\begin{array}{l}\text { ROXY9 overexpression line with the active } \\
\text { site (CCLC) replaced by CCLS in Col- } 0 \text { with } \\
\text { 3XHA fused to the N-terminus of ROXY9 }\end{array}$ & This work \\
\hline 35S:HA-ROXY9AALA & $\begin{array}{l}\text { ROXY9 overexpression line with the active } \\
\text { site (CCLC) replaced by AALA in Col- } 0 \text { with } \\
\text { 3XHA fused to the N-terminus of ROXY9 }\end{array}$ & This work \\
\hline 35S:HA-ROXY9 $\triangle S I L Y$ & $\begin{array}{l}\text { ROXY9 overexpression line with the } \\
\text { C-terminal SILY motif deleted in Col-0 with } \\
\text { 3XHA fused to the N-terminus of ROXY9 }\end{array}$ & This work \\
\hline 35S:HA-ROXY9rALWL & $\begin{array}{l}\text { ROXY9 overexpression line with the } \\
\text { C-terminal SILY motif replaced by ALWL } \\
\text { motif in Col-0 with } 3 \times \mathrm{HA} \text { fused to the }\end{array}$ & This work \\
\hline
\end{tabular}




\begin{tabular}{|l|l|l|}
\hline & N-terminus of ROXY9 & \\
\hline 35S:HA-ROXY8 & $\begin{array}{l}\text { ROXY8 overexpression line in Col-0 with } \\
\text { 3XHA fused to the N-terminus of ROXY8 }\end{array}$ & This work \\
\hline
\end{tabular}

\subsubsection{Plasmids}

\begin{tabular}{|l|l|l|}
\hline Plasmid & Description & Reference \\
\hline pB2GW7.0-HA & $\begin{array}{l}\text { Gateway destination vector for gateway } \\
\text { cloning with N-terminal 3XHA tag and }\end{array}$ & (Weiste et \\
al., 2007) \\
Basta resistance gene for plant \\
selection
\end{tabular}




\begin{tabular}{|c|c|c|}
\hline pB2GW7.0-HA-ROXY8 & $\begin{array}{l}\text { LR reaction result of pB2GW7.0-HA } \\
\text { with pDonor-ROXY8 }\end{array}$ & This work \\
\hline pDONR207 & $\begin{array}{l}\text { Gateway entry vector with Gentamicin } \\
\text { resistance }\end{array}$ & Invitrogen \\
\hline pDONR207-ROXY9 & $\begin{array}{l}\text { BP reaction result of pDonor207 with } \\
\text { DNA fragment ROXY9 }\end{array}$ & $\begin{array}{l}\text { Dr. Martin } \\
\text { Muthreich }\end{array}$ \\
\hline pDONR207-ROXY9SCLC & $\begin{array}{l}\text { BP reaction result of pDonor207 with } \\
\text { DNA fragment ROXY9SCLC which the } \\
\text { ROXY9 active site (CCLC) was replaced } \\
\text { by SCLC }\end{array}$ & $\begin{array}{l}\text { Moritz } \\
\text { Willmer }\end{array}$ \\
\hline pDONR207-ROXY9CSLC & $\begin{array}{l}\text { BP reaction result of pDonor207 with } \\
\text { DNA fragment ROXY9CSLC which the } \\
\text { ROXY9 active site (CCLC) was replaced } \\
\text { by CSLC }\end{array}$ & $\begin{array}{l}\text { Moritz } \\
\text { Willmer }\end{array}$ \\
\hline pDONR207-ROXY9CCLS & $\begin{array}{l}\text { BP reaction result of pDonor207 with } \\
\text { DNA fragment ROXY9CCLS which the } \\
\text { ROXY9 active site (CCLC) was replaced } \\
\text { by CCLS }\end{array}$ & $\begin{array}{l}\text { Moritz } \\
\text { Willmer }\end{array}$ \\
\hline pDONR207-ROXY8 & $\begin{array}{l}\text { BP reaction result of pDonor207 with } \\
\text { DNA fragment ROXY8 }\end{array}$ & This work \\
\hline
\end{tabular}

\subsubsection{Primers}

\subsubsection{Primers for real-time PCR}

\begin{tabular}{|l|l|l|}
\hline Abr. & Primer & Sequences $\left(\mathbf{5}^{\prime}-\mathbf{3}^{\prime}\right)$ \\
\hline 126 & SHYG qRT For & GCATGAATATCGTCTTGCCGATTC \\
\hline 127 & SHYG qRT Rev & GGCAAAGAACCCAATCATCCAGTC \\
\hline 128 & EXPA8 qRT For & CCTCTCCAACGATAATGGAGGTTG \\
\hline 129 & EXPA8 qRT Rev & TGGTACTCTTCGGAAAGAGACAGG \\
\hline
\end{tabular}




\begin{tabular}{|c|c|c|}
\hline 130 & EXPA11 qRT For & GCTTCTGGAACAATGGGTGGAG \\
\hline 131 & EXPA11 qRT Rev & TTAACGCCGCCGTCATTGTC \\
\hline 332 & GH3.6 qRT For & TCACCACCTATGCTGGGCTTTAC \\
\hline 333 & GH3.6 qRT Rev & TGAAACCAGCCACGCTTAGGAC \\
\hline 342 & IAA19 qRT For & TGACGTCGTCGGGTAGTAATAGTG \\
\hline 343 & IAA19 qRT Rev & AGCGTCACCACCAGATGAAACG \\
\hline 352 & XTH8 qRT For & TCTATCGCAGCAACACCGACAC \\
\hline 353 & XTH8 qRT Rev & TGCTTTGTCTGAAATCCACATCCG \\
\hline 318 & XTH33 qRT For & AGCTGGGTTGGTGTCAAAGAAC \\
\hline \multirow[t]{11}{*}{319} & XTH33 qRT Rev & AATCCAGCGGGAAGCTTGAGTC \\
\hline & ROXY1 qRT For & AGCTTAGGATTCGGCGGTTTGG \\
\hline & ROXY1 qRT Rev & AGCCAGGGACTCTATACGAAGCAG \\
\hline & ROXY2 & QuantiTect QT00829031 \\
\hline & ROXY3 qRT For & TTAGGCTGTAGCCCTACGGTTC \\
\hline & ROXY3 qRT Rev & TGGCCGTTCCTACGAATTTCCC \\
\hline & ROXY4 & QuantiTect QT00797622 \\
\hline & ROXY5 & QuantiTect QT00725788 \\
\hline & ROXY6 & QuantiTect QT00852516 \\
\hline & ROXY7 & QuantiTect QT00760144 \\
\hline & ROXY8 & QuantiTect QT00797629 \\
\hline 102 & ROXY9 qRT For & CTAGCCATCATCAGATCTTCAGAC \\
\hline \multirow[t]{7}{*}{106} & ROXY9 qRT Rev & TGGGACAAGAGAGCCACTAAGGTG \\
\hline & ROXY10 qRT For & AGCCAACGAGGTCATGAGTCTAC \\
\hline & ROXY10 qRT Rev & AGCCCGCTTAAGCATGGGAATC \\
\hline & ROXY11 qRT For & GCGTGAACCCGACGATCTATGAAC \\
\hline & ROXY11 qRT Rev & CCTATGAACACCACTGGCACTGTC \\
\hline & ROXY12 qRT For & ACTTTGGCGTGAACCCGACTATC \\
\hline & ROXY12 qRT Rev & CCAATGCTTGCTCTATCTCCCTTC \\
\hline
\end{tabular}




\begin{tabular}{|l|l|l|}
\hline 377 & ROXY13 qRT For & TCCATCTCAATCGCTCTCTGGTTC \\
\hline 378 & ROXY13 qRT Rev & ATCAAAGCCATAGTGCTCCAACCC \\
\hline & ROXY14 qRT For & TTCATAGGAGGGCAGCTTGTCG \\
\hline & ROXY14 qRT Rev & AGCATTGGAATGAGAGAACGGTTG \\
\hline & ROXY15 qRT For & TTGGCGTGAACCCGACAATC \\
\hline & ROXY15 qRT Rev & GCCAAGCTGAGCCAATGCATAC \\
\hline & ROXY16 & QuantiTect QT00868077 \\
\hline & ROXY17 & QuantiTect QT00797608 \\
\hline & ROXY18 & QuantiTect QT00867314 \\
\hline 388 & ROXY19 & QuantiTect QT00869715 \\
\hline 389 & ROXY20 qRT For & CGTTGGAGTTCACCCAACAGTG \\
\hline & ROXY20 qRT Rev & ACGGCGAGGTAAGCAATTTCTCC \\
\hline & ROXY21 & QuantiTect QT00820407 \\
\hline
\end{tabular}

\subsubsection{Primers for cloning}

\begin{tabular}{|l|l|l|}
\hline Abr. & Primer & Sequences (5' $\left.{ }^{\prime} \mathbf{3}^{\prime}\right)$ \\
\hline 153 & ROXY9 SILY removed For & $\begin{array}{l}\text { CATTGATCAAACCCTATCAGTAGTCCCTTCCGA } \\
\text { CCCAGC }\end{array}$ \\
\hline 154 & ROXY9 SILY removed Rev & $\begin{array}{l}\text { GCTGGGTCGGAAGGGACTACTGATAGGGTTT } \\
\text { GATCAATG }\end{array}$ \\
\hline 155 & ROXY9 SILY replaced by & $\begin{array}{l}\text { CATTGATCAAACCCTATCAGgctctctggctcTAGT } \\
\text { CCCTTCCGACCCAGC }\end{array}$ \\
\hline 156 & ALWL For & $\begin{array}{l}\text { GCTGGGTCGGAAGGGACTAGAGCCAGAGAG } \\
\text { CCTGATAGGGTTTGATCAATG }\end{array}$ \\
\hline & ALWL Rev & TCGCGTTAACGCTAGCATGGATCTC \\
\hline & Seq-L1 & GTAACATCAGAGATTTTGAGACAC \\
\hline
\end{tabular}




\subsubsection{Chemicals, kits and antibodies}

\subsubsection{Chemicals}

\begin{tabular}{|c|c|}
\hline Chemical & Source \\
\hline 1-Aminocyclopropane-carboxylic acid (ACC) & Calbiochem \\
\hline Acrylamide/Bisacrylamide & Sigma-Aldrich \\
\hline 2-Mercaptoethanol & Carl Roth \\
\hline Agarose & Biozym \\
\hline Ammonium persulfate (APS) & Biometra \\
\hline Ammonium thiocyanate & Sigma-Aldrich \\
\hline Bromophenol blue & Roth \\
\hline Bovine serum albumin (BSA) & Serva \\
\hline Dimethylsulfoxid (DMSO) & Carl Roth \\
\hline Ethylenediaminetetraacetic acid (EDTA) & Applichem \\
\hline Ethidiumbromide & Roth \\
\hline Fat-free milk powder & commercial \\
\hline Fluoresceine & BioRad \\
\hline Glycerine & Roth \\
\hline Glycerol & Sigma \\
\hline Guanidinium thiocyanate & Sigma \\
\hline luminol & Sigma Aldrich \\
\hline 2-(N-morpholino) ethanesulfonic acid (MES) & Roth \\
\hline Murashige and Skoog medium (MS medium) & Duchefa \\
\hline Sodium acetate & Roth \\
\hline Orange G & Sigma \\
\hline Peptone BD & Biosciences \\
\hline Phenol & Sigma \\
\hline Select Agar & Life Technologies \\
\hline Select yeast extract & Gibco BRL \\
\hline
\end{tabular}




\begin{tabular}{|l|l|}
\hline Sodium salicylate & Sigma-Aldrich \\
\hline Sodium lauryl sulfate (SDS) & Roth \\
\hline Sucrose & Roth \\
\hline SYBR Green I & Cambrex \\
\hline Tryptone & Oxoid \\
\hline Tween20 & Roth \\
\hline Tris & Roth \\
\hline Urea & Sigma \\
\hline
\end{tabular}

\subsubsection{Kits and Enzymes}

\begin{tabular}{|c|c|}
\hline Kit and Enzyme & Source \\
\hline Nucleo Spin ${ }^{\circledast}$ Gel and PCR Clean-up & Macherey-Nagel \\
\hline Nucleo Spin ${ }^{\circledR}$ Plasmid & Macherey-Nagel \\
\hline Phusion High-Fidelity DNA Polymerase & Thermo Scientific \\
\hline RevertAid Reverse Transcriptase & Thermo Scientific \\
\hline BIOTAQ ${ }^{\text {TM }}$ PCR Kit & Bioline \\
\hline Advantage $^{\circledR} 2$ Polymerase Mix & Clontech \\
\hline Gateway ${ }^{\circledR}$ Technology kit & Invitrogen \\
\hline Pierce 660nm Protein Assay Reagent & Thermo Scientific \\
\hline SuperSignal ${ }^{\mathrm{TM}}$ West Femto kit & Thermo Scientific \\
\hline
\end{tabular}

\subsubsection{Antibodies}

\begin{tabular}{|l|l|l|}
\hline Antibody & Description & Source \\
\hline anti-HA (ChIP grade) & $\begin{array}{l}\text { Monoclonal antibody against HA tag from } \\
\text { rabbit }\end{array}$ & Abcam \\
\hline Anti-rabbit & HRP-conjugated anti rabbit IgG from goat & $\begin{array}{l}\text { Life } \\
\text { Technologies }\end{array}$ \\
\hline
\end{tabular}




\subsubsection{Standards}

\begin{tabular}{|l|l|}
\hline Standard & Source \\
\hline GeneRuler DNA Ladder Mix & MBI Fermentas \\
\hline Prestained Protein Ladder & MBI Fermentas \\
\hline
\end{tabular}

\subsubsection{Devices}

\begin{tabular}{|c|c|}
\hline Device & Source \\
\hline arium $^{\circledR}$ pro DI Ultrapure Water deionization device & Sartorius \\
\hline Chemocam & Intas \\
\hline Gene Pulser ${ }^{\circledR}$ II & BioRad \\
\hline MyCyclert ${ }^{\mathrm{TM}}$ thermocycler & BioRad \\
\hline Pico17 microcentrifuge & Thermo Scientific \\
\hline pH -Meter HI2212 & Hanna Instruments \\
\hline Photometer Libra S11 & Biochrom \\
\hline Real-time PCR iCycler & BioRad \\
\hline NanoDrop 2000 & Thermo Scientific \\
\hline Vacuum pump Cyclo 1 & Roth \\
\hline
\end{tabular}




\subsection{Methods}

\subsubsection{Plant growth and treatments}

All lines used were in the Columbia-0 (Col-0) background. Seeds were surface-sterilized by gas $\left(\mathrm{Cl}_{2}\right.$, generated by mixing of $100 \mathrm{ml}$ sodium hypochlorite and $5 \mathrm{ml}$ hydrochloric acid) for two hours before sowing on soil (steamed and supplied with $0,5 \mathrm{ml} / \mathrm{L}$ Wuxal as fertilizer). After keeping at $4^{\circ} \mathrm{C}$ for 2 days for stratification, they were shifted to climate chambers.

For testing hyponastic growth (the study of petiole angles or gene expression), plants were grown at $22^{\circ} \mathrm{C}$ in short-day $(60 \%$ relative humidity, 12-h-light/12-h-dark, fluence rate of $100-120 \mu \mathrm{mol} \mathrm{m} \mathrm{m}^{-1}$ ). Absolute petiole angles were measured using Image J analysis of photographs. Straight lines were drawn between the adaxial surface of the petiole of leaf number 7 or 8 and the horizontal plane.

For propagating seeds, plants were grown at $22^{\circ} \mathrm{C}$ in long-day $(60 \%$ relative humidity, 16-h-light/8-h-dark, fluence rate of 100-120 $\mu \mathrm{mol} \mathrm{m} \mathrm{m}^{-2} \mathrm{~s}^{-1}$ ).

\subsubsection{Low light treatment}

Low light was performed by reducing the light intensity from 100 120 to $15 \sim 20$ $\mu \mathrm{mol} \mathrm{m} \mathrm{m}^{-2} \mathrm{~s}^{-1}$ and it was always initiated 1.5 hours after photoperiod the started to minimize circadian clock effects.

\subsubsection{Light shifting treatment}

Light shifting assay was conducted in two steps: low light pretreatment and afterwards control light treatment. For low light pretreatment, it was initiated 1.5 hours after the beginning of the light period with reduction of the light intensity from $100 \sim 120$ to $15 \sim 20 \mu \mathrm{mol} \mathrm{m} \mathrm{s}^{-2} \mathrm{~s}^{-1}$ until nearly end of the photoperiod in the climate chamber. For afterwards control light treatment, the low light pretreatment plants 
were shifting back to control light directly before the lights went off and photographs were taken or petioles were harvested 7.5 hours after the beginning of the second light period.

\subsubsection{ACC treatment}

Four-week-old soil-grown plants grown under SD (12-h-light/12-h-dark) conditions were sprayed with $1 \mathrm{mM}$ ACC until the surfaces were equally moistened. Control plants were sprayed with water.

\subsubsection{SA treatment}

Four-week-old soil-grown plants grown under SD (12-h-light/12-h-dark) conditions were sprayed with $1 \mathrm{mM}$ SA until the surfaces were equally moistened. SA treatment was initiated 1 hour after low light treatment. Control plants were sprayed with water

\subsubsection{Molecular biology methods}

\subsubsection{Overlap extension PCR cloning}

Overlap extension PCR cloning was performed for making mutations of different sites of ROXY9 using pDONOR 207-ROXY9 as a template. The first two PCRs were performed using chimeric primers combined with vector specific primers to create an overlapping part at both ends (namely PCR fragment 1 and fragment 2) so that the final PCR products have overlapping regions. PCR products were subsequently purified using the Nucleospin Extract II Gel Extraction kit (Macherey-Naggel, Germany). After determining the concentration of each DNA fragments using NanoDrop 2000, equimolar amounts of purified two fragments were used as 
template in a new PCR reaction. The new DNA fragments containing hybridized insert mutation sites were amplified using vector specific primers. PCR reactions were performed using Phusion High-Fidelity DNA Polymerase (Thermo scientific) with a MyCycler ${ }^{\mathrm{TM}}$ Bio-Rad thermocycler. LR reactions were performed to clone the products into Gateway destination vector.

Overlap extension PCR reaction

\begin{tabular}{|c|c|c|c|}
\hline \multicolumn{2}{|l|}{ PCR1 } & \multicolumn{2}{|l|}{ PCR2 } \\
\hline Component & Amount & Component & Amount \\
\hline Plasmid DNA & 100 ng & Plasmid DNA & $100 \mathrm{ng}$ \\
\hline Phusion DNA Polymerase & $0.5 \mu l$ & Phusion DNA Polymerase & $0.5 \mu l$ \\
\hline 5x PCR buffer & $10 \mu \mathrm{l}$ & 5x PCR buffer & $10 \mu \mathrm{l}$ \\
\hline $10 \mathrm{mM}$ dNTPs & $1 \mu l$ & $10 \mathrm{mM}$ dNTPs & $1 \mu l$ \\
\hline $10 \mu \mathrm{M}$ pDONOR For & $1 \mu l$ & $10 \mu \mathrm{M}$ Gene For & $1 \mu l$ \\
\hline $10 \mu \mathrm{M}$ Gene Rev & $1 \mu l$ & $10 \mu \mathrm{M}$ pDONOR Rev & $1 \mu l$ \\
\hline $\mathrm{H} 2 \mathrm{O}$ & $35.5 \mu \mathrm{l}$ & $\mathrm{H} 2 \mathrm{O}$ & $35.5 \mu \mathrm{l}$ \\
\hline
\end{tabular}

PCR3

\begin{tabular}{ll}
\hline Component & Amount \\
\hline PCR1 product & $100 \mathrm{ng}$ \\
PCR2 product & $100 \mathrm{ng}$ \\
Phusion DNA Polymerase & $10 \mu \mathrm{l}$ \\
$5 x$ PCR buffer & $1 \mu \mathrm{l}$ \\
$10 \mathrm{mM}$ dNTPs & $1 \mu \mathrm{l}$ \\
$10 \mu \mathrm{M}$ pDONOR For & $1 \mu \mathrm{l}$ \\
$10 \mu \mathrm{M}$ pDONOR Rev & \\
H2O & \\
\hline
\end{tabular}

Total $50 \mu \mathrm{l}$ 


\begin{tabular}{lll}
\hline Cycle steps & $\begin{array}{l}\text { Temperature } \\
\text { and duration }\end{array}$ & Cycles \\
\hline Initial denaturation & $98^{\circ} \mathrm{C}, 2 \mathrm{~min}$ & 1 \\
\hline Denaturation & $98^{\circ} \mathrm{C} 30 \mathrm{sec}$ & 30 \\
Annealing & $55^{\circ} \mathrm{C}, 30 \mathrm{sec}$ & \\
Extension & $72^{\circ} \mathrm{C}, 1 \mathrm{~min}$ & 1 \\
\hline Final extension & $72^{\circ} \mathrm{C}, 10 \mathrm{~min}$ & 1 \\
\hline Hold & $4^{\circ} \mathrm{C}, \infty$ & \\
\hline
\end{tabular}

\subsubsection{Plasmid extraction}

E.coli cells were collected by centrifuge for $15 \mathrm{sec}$ and plamids were isolated using the Nucleospin Mini kit (Macherey and Nagel).

\subsubsection{Measurement of DNA and RNA concentrations}

Thermo Scientific ${ }^{\mathrm{TM}}$ NanoDrop 2000 was used to quantify and assess the purity of nucleic acids. $1 \mu$ of DNA (plasmid) or RNA was used for measurement at a wave length of $260 \mathrm{~nm}$. The sample purity was calculated by the ratio $260 / 280 \mathrm{~nm}$. The optimal ratio for DNA is OD260/OD280 $\approx 1.8$ and for RNA is 1.9 2.0.

\subsubsection{Gateway cloning}

The Invitrogen GATEWAY ${ }^{\circledR}$ Technology was used for constructing the entry vectors and destination vectors. The vectors were made by following the steps described in the Invitrogen manual. 


\subsubsection{Gene transfer into $E$. coli}

The transformation was performed with the heat shock method according to Hanahan (1983). E. coli competent cells (DH5 $\alpha, 200 \mu \mathrm{l}$ ) were thawed on ice for a few minutes. BP or LR reaction results were added and the mixtures were incubated on ice for $30 \mathrm{~min}$. Heat shock was performed at $42^{\circ} \mathrm{C}$ for $90 \mathrm{sec}$ after which the cells were immediately placed on ice for $2 \mathrm{~min} .1 \mathrm{ml} \mathrm{dYT}$ was added to the ice-cold cells. After 1 hour recovery at $37^{\circ} \mathrm{C}$, the cells were streaked on dYT plates supplemented with required antibiotics. Plates were incubated overnight at $37^{\circ} \mathrm{C}$.

\subsubsection{Gene transfer into A. tumefaciens}

The transformation was performed with electroporation method according to Mattanovich (1989). Cells of $A$. tumefaciens GV3101 strain (40 $\mu$ l) were thawed on ice for a few minutes before adding $100 \mathrm{ng}$ of plasmid. The mixtures were then transferred to an electroporation cuvette following by a single electric pulse (2.5 kV, $25 \mu \mathrm{F}, 400 \mathrm{~W})$ using GenePulser II equipment. The cells were immediately washed out with $1 \mathrm{ml} \mathrm{YEB}$ into a new e-tube and incubated for 2 hours at $29^{\circ} \mathrm{C}$. The cells were then streaked on YEB plates supplemented with required antibiotics. Plates were incubated at $29^{\circ} \mathrm{C}$ for 2 days.

\subsubsection{Arabidopsis transformation}

Floral dip method was used for Agrobacterium-mediated Arabidopsis transformation (Clough and Bent, 1998). Agrobacterium cells, transformed with plasmid of interest, were pre-cultured overnight in $5 \mathrm{ml}$ YEB media supplemented with required antibiotics at $29^{\circ} \mathrm{C}$ with constant shaking. The pre-cultured YEB media was then mixed in a new $400 \mathrm{ml}$ large culture with required antibiotics in the following day and shacked at $29^{\circ} \mathrm{C}$ overnight until $\mathrm{OD} 600 \approx 0.8$. Cells were harvested by centrifugation (4000 rpm, $10 \mathrm{~min}, \mathrm{RT}$ ). After discarding the supernatant, cells were 
re-suspended in $5 \%$ sucrose solution mixed with $0.05 \%$ Silwet-L77. Arabidopsis inflorescences were dipped into the solution for a few seconds. Plants were then covered with hood and placed in a climate chamber overnight. Positive T1 candidates were selected by Basta selection and protein expressions were analyzed by western blot analysis

\subsubsection{Transcript analysis}

\subsubsection{RNA extraction}

TRIZOL method (Chomczynski 1993) was used for plant RNA isolation. Plant powders which were ground in liquid nitrogen were mixed with $1.3 \mathrm{ml}$ of Trizol solution (380 $\mathrm{ml} / \mathrm{L}$ phenol saturated with $0.1 \mathrm{M}$ citrate buffer $\mathrm{pH} 4.3,0.8 \mathrm{M}$ guanidinthiocyanate, $0.4 \mathrm{M}$ ammoniumthiocyanate, $33.4 \mathrm{ml} 3 \mathrm{M} \mathrm{Na}$-acetate $\mathrm{pH} \mathrm{5.2,} \mathrm{5 \%} \mathrm{glycerol).} \mathrm{After}$ immediately vortexing for $10 \mathrm{~min}$ at room temperature, $260 \mu \mathrm{l}$ chloroform was added to each sample and the mixtures were vortexed for another $10 \mathrm{~min}$. The samples were then centrifuged for $60 \mathrm{~min}$ at $13.000 \mathrm{rpm}, 4^{\circ} \mathrm{C}$. The supernatants ( $900 \mu \mathrm{l}$ ) were transferred to new $1.5 \mathrm{ml}$ e-tubes. $325 \mu \mathrm{l}$ of HSB buffer (HSB, $1.2 \mathrm{M} \mathrm{NaCl}, 0.8 \mathrm{M}$ Na-citrate) and $325 \mu$ of 2-propanol were then added. After mixed well by inverting for several times, the samples were centrifuged again for $30 \mathrm{~min}$ at $13.000 \mathrm{rpm}, 4^{\circ} \mathrm{C}$. The supernatants were discarded and the pellets were washed 2 times with $200 \mu \mathrm{l}$ of $70 \% \mathrm{EtOH}$. The pellets were dissolved in $20-60 \mu \mathrm{l}$ de-ionized water after they were completely dried at room temperature and the concentration was measured as described before. 
TRIzol buffer

\begin{tabular}{ll}
\hline Ingredient & Amount per $500 \mathrm{ml}$ \\
\hline $380 \mathrm{ml} / \mathrm{l}$ phenol with citrate buffer & $190 \mathrm{ml}$ \\
$0.8 \mathrm{M}$ guanidinium thiocyanate & $47.264 \mathrm{~g}$ \\
$0.4 \mathrm{M} \mathrm{ammonium}$ thiocyanate & $15.224 \mathrm{~g}$ \\
$33.4 \mathrm{ml} / \mathrm{l} \mathrm{Na}$-acetate (3 M stock) & $16.7 \mathrm{ml}$ \\
$5 \%$ glycerine (100\%) & $25 \mathrm{ml}$ \\
dd $_{2} \mathrm{O}$ & to $500 \mathrm{ml}$ \\
\hline Store at $4^{\circ} \mathrm{C}$ & \\
\hline
\end{tabular}

\subsubsection{2 cDNA synthesis}

$1 \mu \mathrm{g}$ RNA was used for cDNA synthesis. The RNA samples were first incubated with 1 $\mu \mathrm{l}$ DNase together with $1 \mu \mathrm{l}$ 10x DNase buffer (Fermentas) for $30 \mathrm{~min} .1 \mu \mathrm{l} 25 \mathrm{mM}$ EDTA then was added to each sample for denaturing DNase activity. After denaturing at $60^{\circ} \mathrm{C}$ for $10 \mathrm{~min}, 20 \mathrm{pmol}$ of oligo dT primer and $200 \mathrm{pmol}$ of random nonamer oligonucleotides were added and annealed at $70^{\circ} \mathrm{C}, 10 \mathrm{~min}$. Finally, $20 \mathrm{nmol}$ dNTPs, 4 $\mu$ RT $5 x$ reaction buffer and $60 \mathrm{U}$ reverse transcriptase $\mathrm{H}$ (Fermentas) were added and the reaction was incubated at $42^{\circ} \mathrm{C}$ for 70 min followed by incubation at $70^{\circ} \mathrm{C}$ for $10 \mathrm{~min}$. The prepared cDNA was stored at $-20^{\circ} \mathrm{C}$ for further analysis. 
Reaction mix and program for cDNA synthesis

\begin{tabular}{lll}
\hline Stock component & Volume & $\begin{array}{l}\text { Temperature } \\
\text { and duration }\end{array}$ \\
\hline $1 \mathrm{mg} / \mathrm{ml}$ RNA & $1 \mu \mathrm{l}$ & \\
$10 x$ DNase buffer & $1 \mu \mathrm{l}$ & $37^{\circ} \mathrm{C}, 30 \mathrm{~min}$ \\
DNase & $1 \mu \mathrm{l}$ & \\
ddH ${ }_{2} \mathrm{O}$ & to $10 \mu \mathrm{l}$ & \\
\hline $25 \mathrm{mM}$ EDTA & $1 \mu \mathrm{l}$ & $65^{\circ} \mathrm{C}, 10 \mathrm{~min}$ \\
\hline $100 \mu \mathrm{M}$ oligo-dT & $0.2 \mu \mathrm{l}$ & $70^{\circ} \mathrm{C}, 10 \mathrm{~min}$ \\
$200 \mu M$ random monomer & $1 \mu \mathrm{l}$ & \\
\hline $5 \times$ RT-buffer & $4 \mu \mathrm{l}$ & \\
$10 \mathrm{mM}$ dNTPs & $2 \mu \mathrm{l}$ & $42^{\circ} \mathrm{C}, 70 \mathrm{~min}$ \\
Reverse Transcriptase & $0.2 \mu \mathrm{l}$ & then $70^{\circ} \mathrm{C}, 10 \mathrm{~min}$ \\
ddH2O & to $20 \mu \mathrm{l}$ & \\
\hline
\end{tabular}

\subsubsection{Quantitative real-time PCR (qRT-PCR)}

Quantificative real-time PCR was performed using MyiQ ${ }^{\mathrm{TM}}$ Real-Time PCR Detection Systems (Bio-Rad, USA). The primers used in real-time PCR are listed in Table 2.1.3.1. The reaction mixture of real-time PCR was as follows: $1 \mu$ of 1:10 diluted cDNA, $1 x$ NH4-reaction buffer (Bioline), $2 \mathrm{mM} \mathrm{MgCl}$, $100 \mu \mathrm{M}$ dNTPs, $0.4 \mu \mathrm{M}$ primers, $0.25 \mathrm{U}$ BIOTaq DNA polymerase, 10 nM fluoresceine (BioRad), 100,000x diluted SYBR Green I (Cambrex) solution and $17.2 \mu \mathrm{l}$ de-ionized water water (final volume $25 \mu \mathrm{l}$ ). The conditions of real-time PCR were as follows: $95^{\circ} \mathrm{C}$ for $6 \mathrm{~min}, 40$ cycles of $95^{\circ} \mathrm{C}$ for $20 \mathrm{~s}$ and $55^{\circ} \mathrm{C}$ for $20 \mathrm{~s}$, followed by $72^{\circ} \mathrm{C}$ for $40 \mathrm{~s}$. The obtained $\mathrm{Ct}$ values were normalized to housekeeping gene UBQ5 and calculation of relative gene expression was done with the $2^{-[C T(\text { gene of interest)-CT(reference gene)] }}$ method (Schmittgen and Livak, 2008). 


\section{Reaction mix for qRT-PCR using BIOTAQ DNA Polymerase}

\begin{tabular}{ll}
\hline Stock component & Volume in a $25 \mu$ l reaction \\
\hline $10 \mathrm{NH}_{4}$ reaction buffer & $2.5 \mu \mathrm{l}$ \\
$\mathrm{MgCl}_{2} 25 \mathrm{mM}$ & $1 \mu \mathrm{l}$ \\
dNTPs $10 \mathrm{mM}$ & $0.25 \mu \mathrm{l}$ \\
For and Rev primers (each $4 \mathrm{mM})$ & $2.5 \mu \mathrm{l}$ \\
Sybr Green (1/1000) & $0.25 \mu \mathrm{l}$ \\
Fluorescein (1 $\mu \mathrm{M} / 1: 1000)$ & $0.25 \mu \mathrm{l}$ \\
BIOTAQ DNA Polymerase & $0.05 \mu \mathrm{l}$ \\
cDNA template & $1 \mu \mathrm{l}$ \\
\hline
\end{tabular}

Program of qRT-PCR cycler using BIOTAQ DNA Polymerase

\begin{tabular}{lll}
\hline Cycle step and repeat & Temperature and duration & Cycles \\
\hline Initial denaturation & $95^{\circ} \mathrm{C}, 90 \mathrm{sec}$ & 1 \\
\hline Denaturation & $95^{\circ} \mathrm{C}, 20 \mathrm{sec}$ & 39 \\
Annealing & $55^{\circ} \mathrm{C}, 20 \mathrm{sec}$ & \\
Extension & $72^{\circ} \mathrm{C}, 40 \mathrm{sec}$ & 1 \\
\hline Final extension & $72^{\circ} \mathrm{C}, 4 \mathrm{~min}$ & 1 \\
\hline & $95^{\circ} \mathrm{C}, 1 \mathrm{~min}$ & 1 \\
\hline & $55^{\circ} \mathrm{C}, 1 \mathrm{~min}$ & 81 \\
\hline
\end{tabular}




\subsubsection{Microarray analysis}

Four-week soil-grown wild-type, tga1 tga4 were used for transcriptome analysis. For each type of sample, the petioles of 15 plants were harvested and four independent experiments were performed. Total RNA was extracted by TRIZOL method. RNA samples were sent to the transcriptome lab at Goettingen University where the RNA samples were analyzed with Affymetrix GeneChips ${ }^{\circledR}$ Gene 1.0 ST Arrays.

Robust Multi-array Average (RMA) was used to normalize the arrays. Fold change values, and corresponding $p$-values derived from moderated t-statistics were obtained from the Affymetrix CEL files using the Robin 1.1.2 software (Lohse et al., 2010) (analyzed by Dr. Corinna Thurow). The AgriGo analysis tool from website (http://bioinfo.cau.edu.cn/agriGo/) was used for the functional classification of differentially expressed genes. The Motif Mapper (version 5.2.4.01) was used to define significant enriched promoter mitifs compared to 1000 randomly composed, equally sized, reference promoter datasets. (Berendzen et al., 2012)

\subsubsection{Protein analysis}

\subsubsection{Protein extraction}

Proteins of four-week-old soil-grown Arabidopsis plants were harvested for protein extraction. Urea buffer was added to the deep frozen plant powder ( $200 \mu \mathrm{l})$ and the mixture was shaked at $65^{\circ} \mathrm{C}$ for $10 \mathrm{~min}$. Afterwards the solution was centrifuged for $20 \mathrm{~min}$ at $13000 \mathrm{rpm}$ at room temperature and the supernatant was used for further protein expression analysis. 
Protein extraction buffer

\begin{tabular}{ll}
\hline Ingredient & Final concentration \\
\hline Urea & $4 \mathrm{M}$ \\
Glycerol & $16.6 \%(\mathrm{v} / \mathrm{v})$ \\
SDS & $5 \%(\mathrm{w} / \mathrm{v})$ \\
$\beta$-mercaptoethanol & $0.5 \%(\mathrm{w} / \mathrm{v})$ \\
\hline
\end{tabular}

\subsubsection{Determination of protein concentrations}

Protein concentrations were measured with the detection solution which was made by mixing $20 \mathrm{ml}$ of Pierce $660 \mathrm{~nm}$ Protein Assay Reagent with $1 \mathrm{~g}$ of lonic Detergent Compatibility Reagent (IDCR) (Thermo Scientific). $1 \mu$ l of protein extract was added to the well of a microtitre plate together with $150 \mu$ l of detection solution. The reaction was incubated for $5 \mathrm{~min}$ at room temperature. OD was measured at $660 \mathrm{~nm}$ by using the BioTek plate reader. Protein concentrations were determined with the help of standard curve derived from $0 \mu \mathrm{l}, 1 \mu \mathrm{l}, 3 \mu \mathrm{l}, 6 \mu \mathrm{l}, 9 \mu \mathrm{l}$ of $1 \mathrm{mM}$ BSA (Bovine serum albumin).

\subsubsection{SDS-PAGE}

SDS-PAGE (sodium dodecyl sulfate-polyacrylamide gel electrophoresis) was performed according to the method described by Weber (1977). $20 \mu \mathrm{g}$ protein samples were loaded to the stacking gel and the electrophoresis was performed at $70 \mathrm{~V}$ for $30 \mathrm{~min}$ and at $120 \mathrm{~V}$ for 1 hour and $30 \mathrm{~min}$ until bromophenol blue band reached the end of the separation gel. A prestained ladder $(6 \mu \mathrm{l})$ was used for estimating the size of the protein signals. 
Stacking gel $(12 \%, 10 \mathrm{ml})$

\begin{tabular}{ll}
\hline Ingredient & Amount \\
\hline ddH2O & $4.0 \mathrm{ml}$ \\
Acrylamide/ & $3.3 \mathrm{ml}$ \\
Bisacrylamide (37.5:1) & \\
Tris-HCl pH 6.8 & $2.5 \mathrm{ml}$ \\
10\% SDS & $0.1 \mathrm{ml}$ \\
10\% APS & $0.1 \mathrm{ml}$ \\
TEMED & $4 \mu \mathrm{l}$ \\
\hline
\end{tabular}

Separation gel $(12 \%, 10 \mathrm{ml})$

\begin{tabular}{ll}
\hline Ingredient & Amount \\
\hline ddH2O & $6.8 \mathrm{ml}$ \\
Acrylamide/ & $1.7 \mathrm{ml}$ \\
Bisacrylamide $(37.5: 1)$ & \\
Tris-HCl pH 6.8 & $1.25 \mathrm{ml}$ \\
10\% SDS & $0.1 \mathrm{ml}$ \\
10\% APS & $0.1 \mathrm{ml}$ \\
TEMED & $10 \mu \mathrm{l}$ \\
\hline
\end{tabular}

\subsubsection{Immunoblot Analysis}

After separated in $12 \%$ SDS-PAGE gels, proteins were transferred to PVDF (Polyvinylidene difluoride, Roti $^{\circledR}$-PVDF, Roth) membrane using a semi-dry blot method (150 mA, $30 \mathrm{~min})$. The PVDF membrane was then blocked at room temperature for 30 min with $5 \%(\mathrm{w} / \mathrm{v})$ non-fat milk in TBST. Immunoblot analysis was carried out using rat $\alpha-\mathrm{HA}$ antibody. The antigen protein was detected by chemiluminescence using a SuperSignal $^{\mathrm{TM}}$ West Femto Maximum Sensitivity Substrate kit (Thermo scientific) according to the manufacturer's protocol and the luminescence was detected in a chemocam (Intas). 


\section{Results}

\subsection{The tga1 tga4 mutant shows reduced hyponastic growth}

The two redundant transcription factors TGA1 and TGA4 encode conserved redox-sensitive cysteine residues, which might serve as targets of the TGA-interacting ROXY-type glutaredoxins. Although TGA1 and TGA4 have been studied for many years, the functional significance of the SA-mediated redox-modification on the expression of target genes has remained unclear (Després et al., 2003; Shearer et al., 2012). Interestingly, we found that the tga1 tga4 mutant displayed reduced hyponastic growth under various conditions, including low light, ethylene or elevated temperature (Figure 3.1). Due to the robustness and easy scoring of this phenotype, we focused on this novel function of TGA1 and TGA4 in our further analysis.

(A)

wild-type

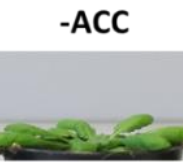
tga1 tga4

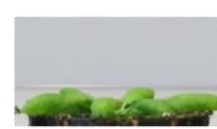

(C)

wild-type

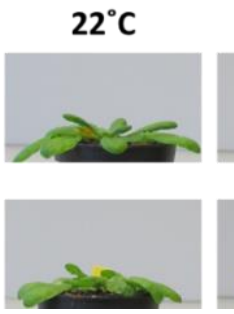

$\operatorname{tga1} \operatorname{tga4}$
$+\mathrm{ACC}$
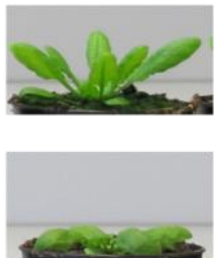

$38^{\circ} \mathrm{C}$
(B) wild-type

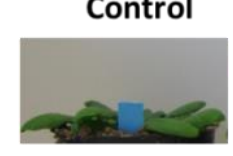

tga1 tga4

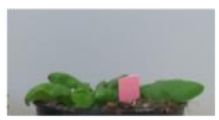

Low light
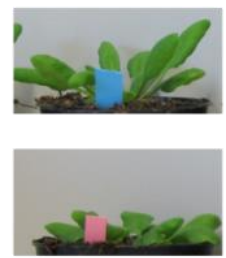
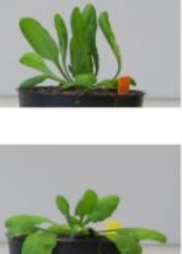

Figure 3.1 The tga1 tga4 mutant is impaired in hyponastic growth.

(A) Representative photographs of wild-type and tga1 tga4 plants after $6 \mathrm{~h}$ of treatment with the ET precursor ACC (1-aminocyclopropane-1-carboxylic acid, 1mM)

(B) Representative photographs of wild-type and tga1 tga4 plants after $6 \mathrm{~h}$ of low light treatment (15-20 $\mu \mathrm{mol}$ photons $\mathrm{m}^{-2} \mathrm{~s}^{-1}$ ).

(C) Representative photographs of wild-type and tga1 tga4 plants after $6 \mathrm{~h}$ of elevated temperature treatment $\left(38^{\circ} \mathrm{C}\right)$.

Before treatments, plants were grown for 4 weeks under short day conditions (12-h-light at 100-120 $\mathrm{mmol}$ photons $\mathrm{m}^{-2} \mathrm{~s}^{-1} / 12$-h-dark, $22^{\circ} \mathrm{C}$ ). 


\subsection{Low light-induced hyponastic growth partially acts through the ethylene and the phototropin pathways}

As shown in Figure 3.1, the $\operatorname{tga1} \operatorname{tga} 4$ mutant shows reduced hyponastic growth, independent of whether the response is triggered by low light, ethylene or heat. In order to estimate whether the ethylene pathway plays a role in the light-induced hyponastic growth under our experimental conditions, we analysed the ethylene-insensitive (ein2-1) mutant (Alonso, et al., 1999). To obtain quantitative data, we measured the angles between leaf petioles and the horizontal plane as shown in Figure 3.2. In the wild-type, petiole angles increased around threefold in response to six hours of low light treatment. This response was diminished in the ein2 mutant. Apparently, the ethylene pathway contributes to the low light-induced hyponastic growth under our growth conditions.

Next, we tested the influence of photoreceptors on the hyponastic response using the phyB (deficient in phytochrome B) (Reed et al., 1993), cry1 cry2 (deficient in cryptomchromes 1 and 2) (Mockler et al., 1999) and phot1 phot2 (deficient in phototropins 1 and 2) mutants (Lariguet et al., 2006). All three mutants behaved differently as described (Millenaar et al., 2009). The phyB mutant (Landsberg) was reported to have constitutively elevated leaves (Mullen et al., 2006; Millenaar et al., 2009), whereas the phyB mutant in the Columbia background had even decreased petiole angles under control light conditions and showed an exaggerated hyponastic response under low light conditions (Figure 3.2C). The cry1 cry2 double mutant in the Landsberg background showed reduced hyponastic growth (Millenaar et al., 2009), which was not observed in our Columbia-derived mutants (Figure 3.2D). Finally, the phot1 phot2 (Landsberg/Wassilewklija) was like wild-type in previous experiments (Millenaar et al., 2009), whereas the respective double mutant in the Columbia background showed impaired hyponastic growth (Figure 3.2D). Since our low light treatment (4-week-old plants grown under a 12-h photoperiod at 100-120 $\mu \mathrm{mol}$ 
photons $\mathrm{m}^{-2} \mathrm{~s}^{-1}$ and subsequent shift to $15-20 \mu \mathrm{mol}$ photons $\mathrm{m}^{-2} \mathrm{~s}^{-1}$ for six hours) is similar to the treatment of Millenaar et al. (2009) (plant with 15 rosette leaves grown under a $9 \mathrm{~h}$ photoperiod at 200 to $20 \mu \mathrm{mol}$ photons $\mathrm{m}^{-2} \mathrm{~s}^{-1}$ ), the use of different ecotypes might explain the discrepancy.

(A)

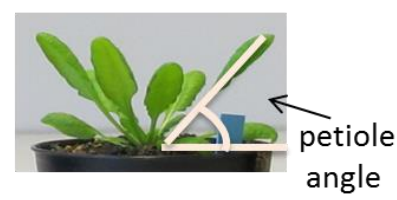

(C)

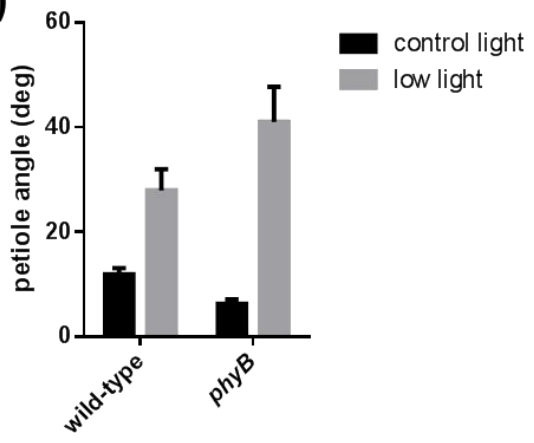

(B)

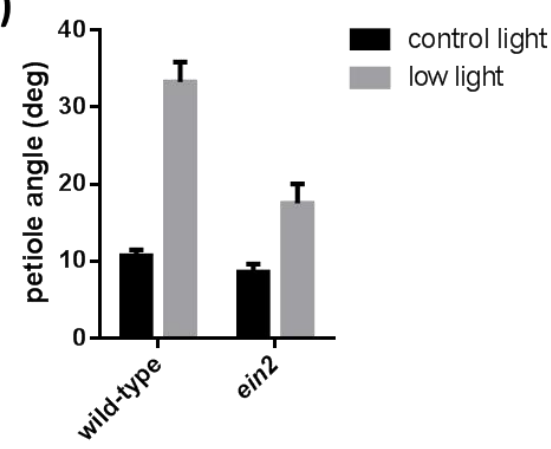

(D)

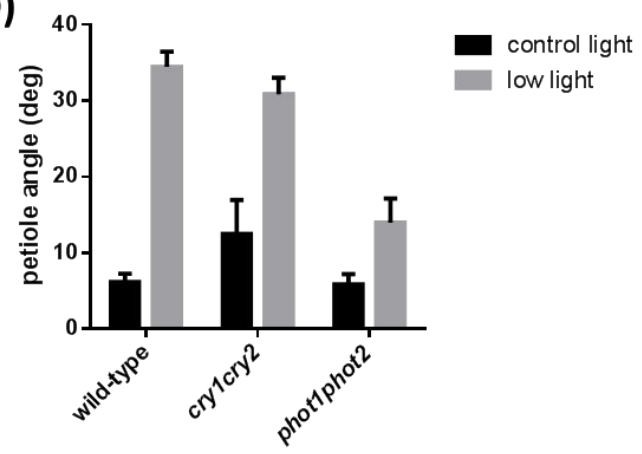

Figure 3.2 Low light-induced hyponastic growth partially acts through the ethylene and the phototropin pathways.

(A) Absolute petiole angles were measured using Image $J$ analysis of photographs. Straight lines were drawn between the adaxial surface of the petiole of leaf number 7 or 8 and the horizontal plane. Plants were grown for 4 weeks under short day conditions (12-h-light at 100-120 $\mu$ mol photons $\mathrm{m}^{-2} \mathrm{~s}^{-1} / 12$-h-dark). Low light treatment $\left(6 \mathrm{~h}\right.$ at $15-20 \mu \mathrm{mol}$ photons $\mathrm{m}^{-2} \mathrm{~s}^{-1}$ ) was initiated $1.5 \mathrm{~h}$ after the start of the photoperiod and photographs were taken after $6 \mathrm{~h}$.

(B-D) Leaf angles of the indicated genotypes were measuread as described in (A). Error bars represent the average \pm SEM of nine plants. The images for petiole angle measurement are shown in Supplementary Figure S6 and Supplementary Figure S7.

Collectively, our analysis has shown that the reduction of the light intensity is at least partially detected by the blue light receptor phototropin which might trigger ethylene synthesis and signaling. However, both mutations do not diminish the response as strongly as the tga1 tga 4 alleles indicating that TGA1 and TGA4 control responses downstream of these and other signaling cascades. 


\subsection{Redox-active cysteines of TGA1 are not important for the regulation of hyponastic growth}

As revealed by the phenotype of the tga1 tga4 mutant, TGA1 and TGA4 are required for hyponastic growth and the regulation of their activity might be a means to control the response. Since transcript levels of both proteins did not change upon transfer of plants to low light (Supplementary Figure S1), we explored, whether the activity of these factors might be modulated at the protein level. Previously, it has been reported that two cysteines in the peptide stretch CNLKQSC in TGA1 can form a disulfide bridge which is reduced in SA-treated plants (Despres et al., 2003). Therefore, we asked the question whether these cysteines are important for the function of TGA1. To this end, the tga1 tga4 mutant was complemented with wild-type and mutant TGA1 sequences. Since CaMV35S:TGA1 constructs cannot complement the tga1 tga4 phenotype (Lindermayr et al., 2010), engineered genomic clones were used. Cysteine residue in position 260 was altered into an asparagine and cysteine residue in position 266 was changed into a serine as described before (Depres et al., 2003). tga1 tga4 mutants transformed with the wild-type gene are called gTGA1 plants from here on, plant lines encoding the mutated gene are called gTGA1cys plants. Both constructs contain an HA-tag at the $\mathrm{N}$ terminus (Figure 3.3A). Seeds containing these constructs were obtained from Prof. Dr. Yuelin Zhang, UBC Vancouver. Two independent lines carrying the gTGA1 and gTGA1cys constructs, respectively, displayed low light-induced leaf re-orientation resembling the wild-type. This analysis shows that the N-terminally tagged TGA1 is functional in this assay, irrespective of whether it contains the redox-regulated cysteines. 

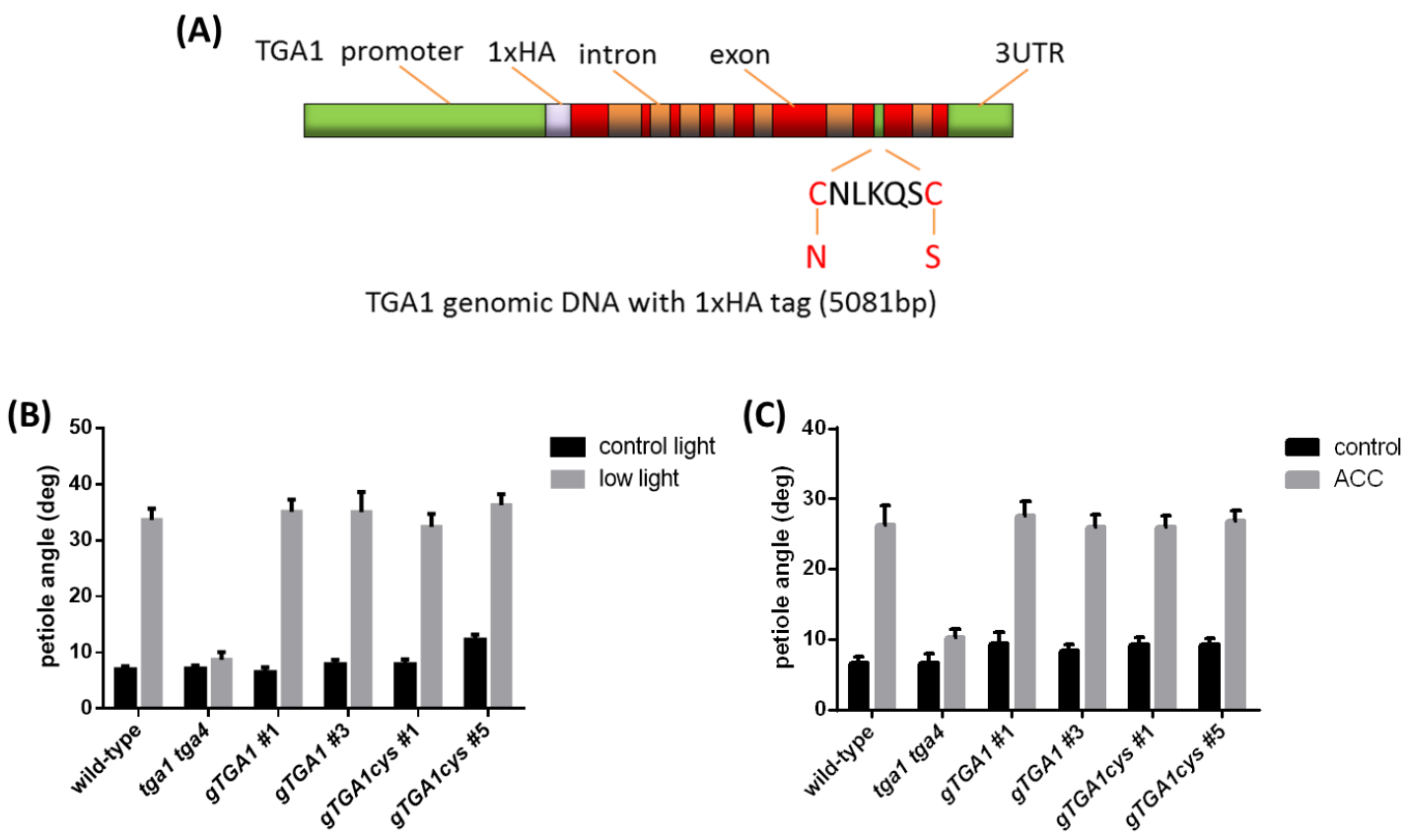

Figure 3.3 Redox-active cysteines of TGA1 are not important for the regulation of hyponastic growth.

(A) Structure of the genomic TGA1 genes ( $g$ TGA1 and gTGAcys) used for complementation assays. The relative position of the redox-active cysteines, which were mutated to asparagine and serine in gTGAcys, respectively, is shown.

(B) Effect of low light treatment (reduction in light intensity from 100-120 to $15-20 \mu \mathrm{mol} \mathrm{m}^{-2} \mathrm{~s}^{-1}$ ) on the hyponastic growth of wild-type, tga1 tga4, and two independent transgenic gTGA1 and gTGA1cys complementation lines. See Figure legend 3.2 for details of plant growth and leaf angle measurements. Bars represent the average \pm SEM of ten plants. The images for petiole angle measurement are shown in Supplementary Figure 59.

(C) Effect of ACC (1-aminocyclopropane-1-carboxylic acid, $1 \mathrm{mM}, 6 \mathrm{~h}$ ) on the hyponastic growth of the indicated plant lines. Plants were grown for 4 weeks under short day conditions (12-h-light/12-h-dark) before treatment. Bars represent the average \pm SEM of ten plants. The images for petiole angle measurement are shown in Supplementary Figure S8. 


\subsection{Redox-active cysteines of TGA1 are not important for salicylic acid-mediated inhibition of hyponastic growth}

Since exogenous salicylic acid (SA) leads to the reduction of C260 and C266 of TGA1 in vivo (Després et al., 2003) and since it interferes with low light-induced hyponastic growth (Ritsema, et al., 2010), we hypothesized that the redox-active cysteines might play a role in this effect. Therefore, wild-type, tga1 tga4 and gTGA1 and gTGA1cys complementation lines were transferred to low light. After transfer, half of the plants were sprayed with $1 \mathrm{mM} \mathrm{SA}$, which led to a reduced hyponastic response in wild-type and the complementation lines. This experiment indicates that the SA-mediated redox modulation does not play a role for the negative effect of SA on hyponastic growth

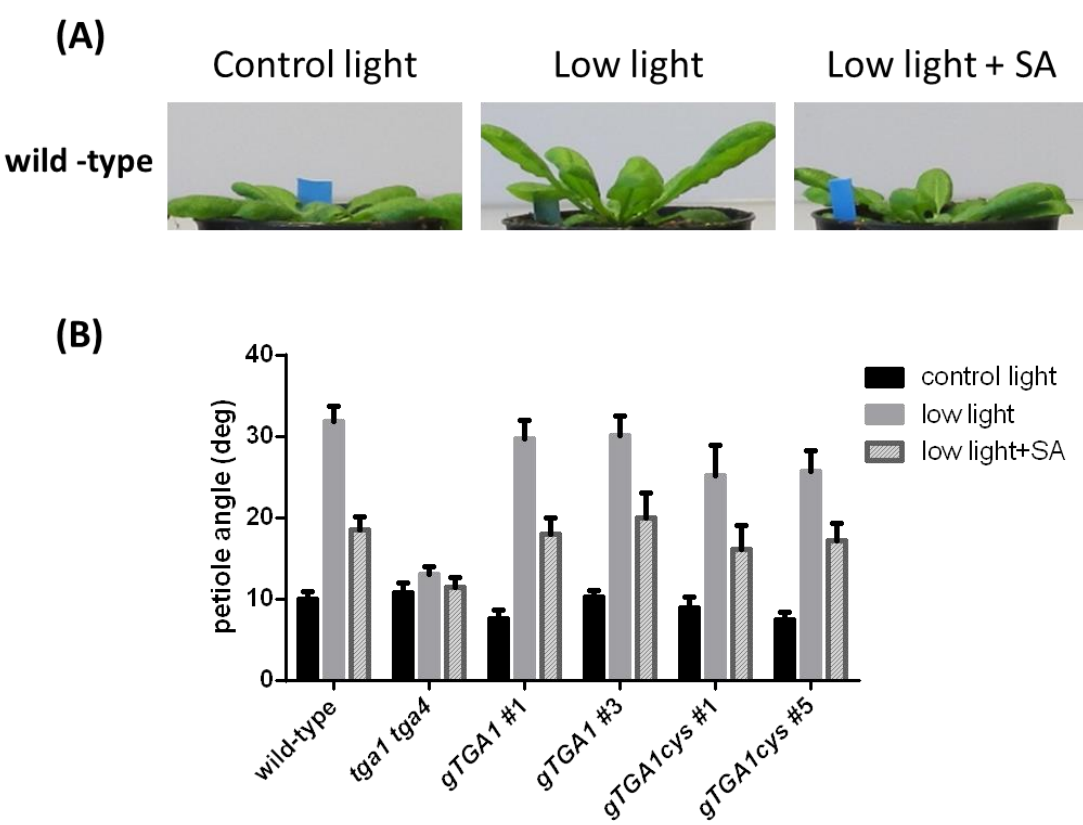

Figure 3.4 Redox-active cysteines of TGA1 are not important for salicylic acid-mediated inhibition of hyponastic growth.

(A) Representative pictures of plants subjected to low light (reduction in light intensity from 100-120 to $15-20 \mu \mathrm{mol} \mathrm{m}^{-2} \mathrm{~s}^{-1}$ ) or low light in combination with $1 \mathrm{mM} \mathrm{SA}$, which was sprayed $1 \mathrm{~h}$ after the onset of the low light treatment.

(B) Effect of low light or low light in combination with $1 \mathrm{mM} \mathrm{SA}$ on the hyponastic growth of wild-type, tga1 tga4, and two independent gTGA1 and gTGA1cys lines. See Figure legend 3.2 for details of plant growth and leaf angle measurements. Bars represent the average \pm SEM of 10 plants. The images for petiole angle measurement are shown in Supplementary Figure S10. 


\subsection{NPR1 and the redundant TGA factors TGA2, TGA5 and TGA6 are required for SA-mediated inhibition of hyponastic growth}

SA-mediated suppression of low light-induced hyponasty was further tested in the npr1-1 mutant, in which SA-activated gene expression and systemic acquired resistance are abolished (Cao et al., 1994). Increased petiole angles can be triggered by low light in the npr1-1 mutant as well as in wild-type (Figure 3.5). However, the SA-mediated suppression of low light-induced leaf reorientations was almost abolished in npr1-1. Since NPR1 and the redundant TGA factors TGA2, TGA5 and TGA6 function together to establish and maintain systemic acquired resistance and in suppressing of the jasmonic acid-induced defense pathway (Cao et al., 1994; Spoel et al., 2003; Zhang et al., 2003; Zander et al., 2009), we asked whether they control SA-mediated suppression of hyponastic growth as well. As shown in Figure 3.5, SA cannot suppress low light-induced leaf movement in the tga $2 \operatorname{tga} 5 \operatorname{tga} 6$ mutant. It is concluded that TGA2, TGA5, and TGA6 but not TGA1 and TGA4 are required for SA-mediated inhibition of hyponastic growth.

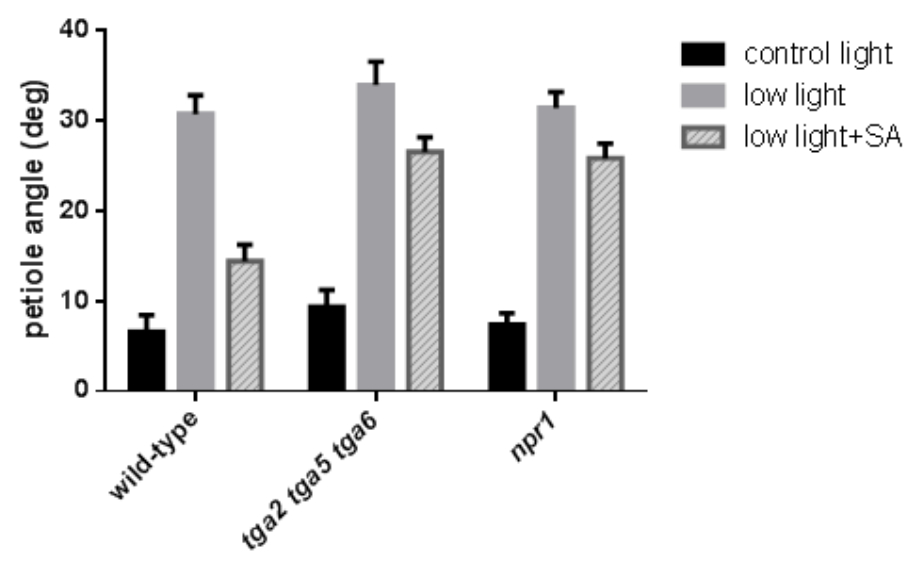

Figure 3.5 NPR1 and TGA2, TGA5 and/or TGA6 are required for SA-mediated inhibition of hyponastic growth.

Four-week-old soil-grown wild-type, tga2 tga5 tga6, and npr1-1 plants were subjected to low light and low light plus $1 \mathrm{mM}$ SA treatment. See Figure legend 3.2 for details of plant growth and leaf angle measurements. Error bars represent the average \pm SEM of 6 individual plants. The images for petiole angle measurement are shown in Supplementary Figure S11. 


\subsection{The redox state of TGA1/TGA4 is not important for the reversal of hyponastic growth after transferring low light-treated plants back to control light intensities}

(A)

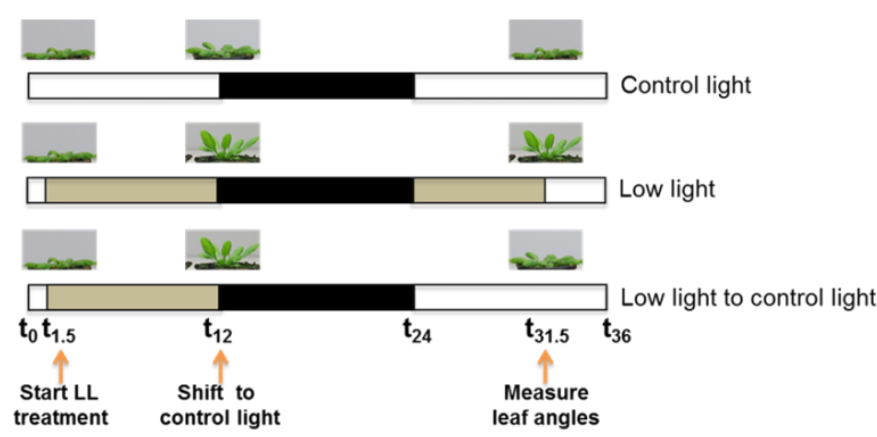

(B)

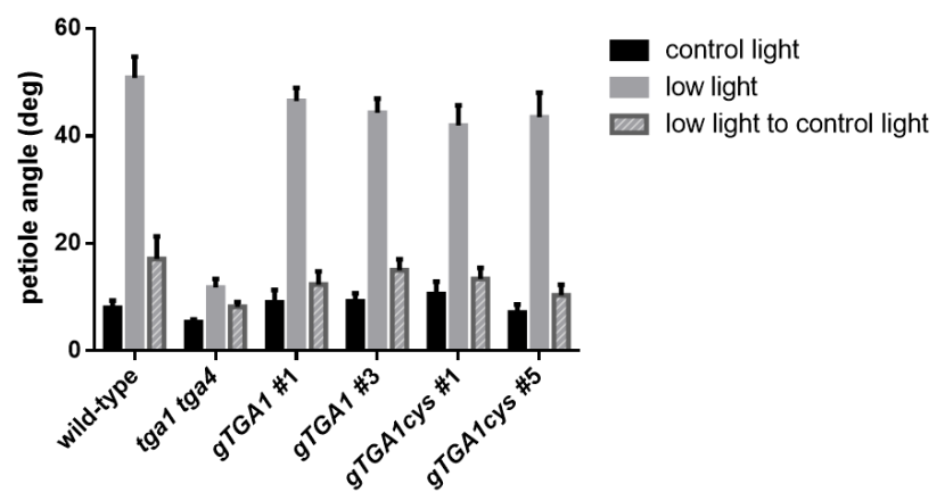

Figure 3.6 The redox state of TGA1/TGA4 is not important for the reversal of hyponastic growth after the transfer of low light-treated plants back to control light conditions.

(A) Scheme of the experimental design. Four-week-old plants were grown under a 12-h-light/12-h-dark regime. Low light (LL) treatment was initiated 1.5 hours after the beginning of the light period $\left(t_{1.5}\right)$. Plants were transferred back to control light shortly before the lights went off $\left(t_{12}\right)$ and plants were analysed after $7.5 \mathrm{~h}$ of the second light period $\left(\mathrm{t}_{31.5}\right)$.

(B) Plants of the indicated genotypes were subjected to the light regime displayed in (A). Petiole angles were measured at $t_{31.5}$. Error bars represent the average \pm SEM of 8 individual plants. The images for petiole angle measurement are shown in Supplementary Figure S12.

Next, we tested whether the redox state of TGA1 might play a role in the reversal of the hyponastic growth which is observed after transferring low light-treated plants to control light conditions. As described before, low light treatment was initiated 1.5 hours after the start of the photoperiod but was continued in this experiment for 10.5 hours. When the dark period started, half of the plants were transferred to a different growth chamber so that they would face control light conditions in the next 
morning, whereas half of the plants would face low light conditions after the dark period. Plant leaves of all tested genotypes became more horizontal at 7.5 hours after transfer to control light conditions (Figure 3.6). Collectively, our results suggest that the redox state of TGA1/TGA4 is not important for either initiating or terminating low light-induced hyponastic growth in Arabidopsis.

\subsection{The expression pattern of CC-type glutaredoxins ROXY8 and ROXY9} is consistent with their potential role as repressors of TGA1 and TGA4

Next we searched for other potential mechanisms that might regulate the activity of TGA1 and TGA4. TGA transcription factors interact with CC-type glutaredoxins, which are represented by a 21-membered gene family in Arabidopsis (Ziemann et al., 2009). The interaction seems to interfere with TGA factor activity, as demonstrated for ROXY1, which represses the TGA factor PAN. Both factors are co-expressed in floral meristems (Li et al., 2009). Furthermore, ROXY19 is induced by SA and represses genes that are regulated by the SA-responsive NPR1/TGA2, TGA5 and/or TGA6 module (Ndamukong et al., 2007; Zander et al., 2012). In order to test which ROXYs might interfere with the activity of TGA1 and TGA4 during hyponastic growth, expression of all 21 CC-type glutaredoxins was analysed by real-time PCR in response to the light regime described in Figure 3.6 (Figure 3.7). Assuming that ROXYs are negative regulators of TGA1 and TGA4, their expression should be low under low light (when the petioles grow upwards) and high under control light conditions. Whereas several ROXYs were induced by low light (ROXY1, ROXY2, ROXY4, ROXY10, ROXY16, ROXY17), the mRNA levels of ROXY9 and ROXY20 were reduced under low light conditions. After the transfer of low-light treated plants to control light conditions transcript levels were induced or even hyper-induced in the case of ROXY9. This hyper-induction is also observed for ROXY8, which belongs to the same clade as ROXY9. In addition, transcript levels of ROXY8, ROXY9 and ROXY2O expression are low in tga1 tga4 (Figure 3.8). This is reminiscent of ROXY19, which controls the activity of TGA2, TGA5 and TGA6 and is regulated by these factors (Ndamukong et al., 2007). In 
addition, we investigated the expression of ROXY9 in the gTGA1 and gTGA1cys complementation lines. Consistent with the wild-type-like phenotype of these plants with respect to light-controlled hyponastic growth, the expression of ROXY9 was repressed by low light and induced after transfer to control light in both lines (Supplementary figure S3). Previously, Dr. Martin Muthreich (Prof. Dr. Christiane Gatz lab, Department of Plant Molecular Biology and Physiology) found that TGA1 and TGA4 interact with ROXY9 in the yeast two hybrid system and in bimolecular fluorescence complementation experiments in Arabidopsis protoplasts. Collectively, our results support a functional relationship between TGA1 and TGA4 and at least ROXY9.
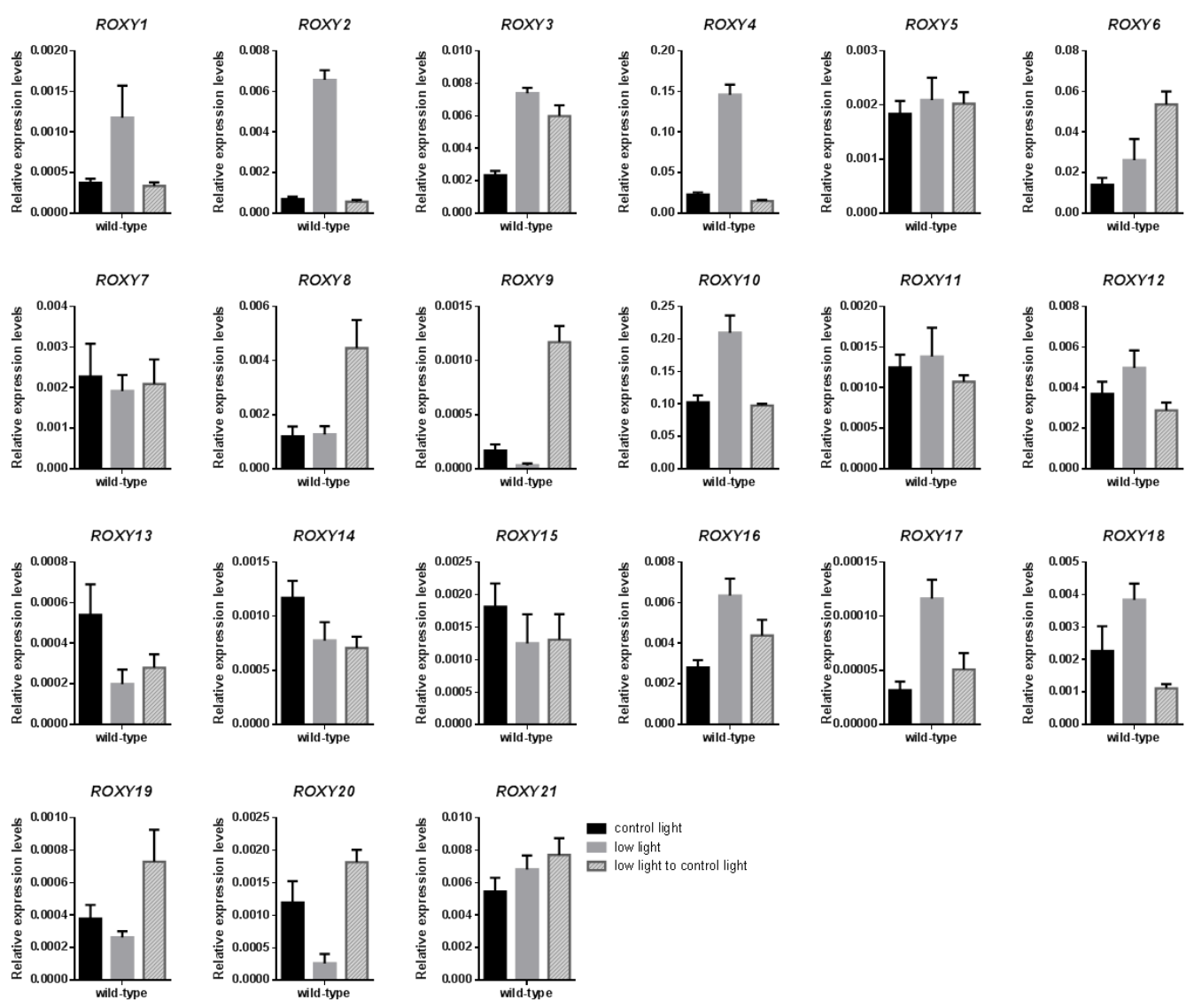

Figure 3.7 Expression of 21 CC-type glutaredoxins

qRT-PCR analysis of 21 ROXYs expression in wild-type. Plants were subjected to the light regime displayed in Figure 3.6A. Transcript levels were normalized to the transcript level of UBQ5 (ubiquitin 5). Error bars represent the average \pm SEM of five biological replicates, each with dissected petioles from five independent plants. 


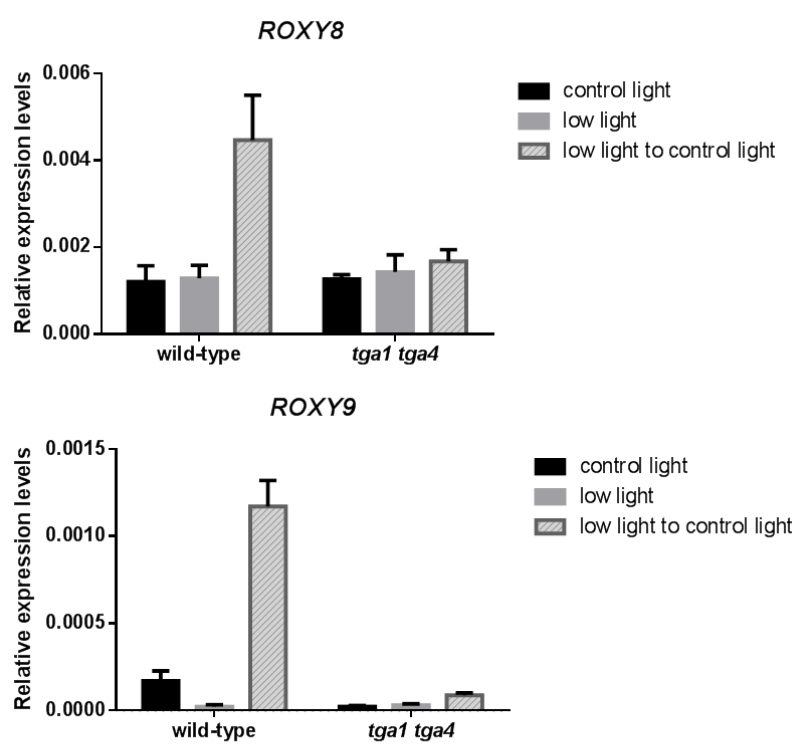

ROXY2O

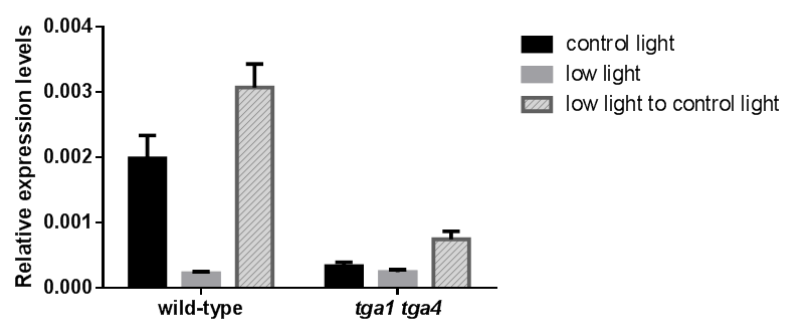

Figure 3.8 Expression of ROXY9 negatively correlates with hyponastic growth and depends on TGA1 and TGA4.

qRT-PCR analysis of ROXY8, ROXY9 and ROXY20 expression. Plants were subjected to the light regime displayed in Figure 3.6A. Transcript levels were normalized to the transcript level of UBQ5 (ubiquitin 5). Error bars represent the average \pm SEM of five biological replicates, each with dissected petioles from five independent plants.

\subsection{Overexpression of ROXY8 or ROXY9 phenocopies the tga1 tga4 phenotype}

Due to the lack of T-DNA insertion mutants in the potentially redundant ROXY8 and ROXY9 genes and the potential redundancy with at least ROXY20, we asked the question whether ROXY8 and ROXY9 can repress hyponastic growth when ectopically expressed under the control of the CaMV 355 promoter. As shown in Figure 3.9, five independent homozygous 35S:HA-ROXY8 and 35S:HA-ROXY9 lines showed reduced degrees of petiole angles in response to low light treatment which is similar to the 
phenotype of the tga1 tga4 double mutant. In contrast, 35S:HA-ROXY19 plants responded like wild-type plants, indicating the hyponasty-deficient phenotype of the 35S:HA-ROXY8 and 35S:HA-ROXY9 ROXY8/9 lines requires specific features of the proteins which are not present in ROXY19. Consistent with the concept that ROXY19 represses the function of clade II TGA TFs, 35S:HA-ROXY19 plants did not react to the negative signal SA, as observed before for the tga 2 tga5 tga6 mutant (Figure 3.5)

(A)

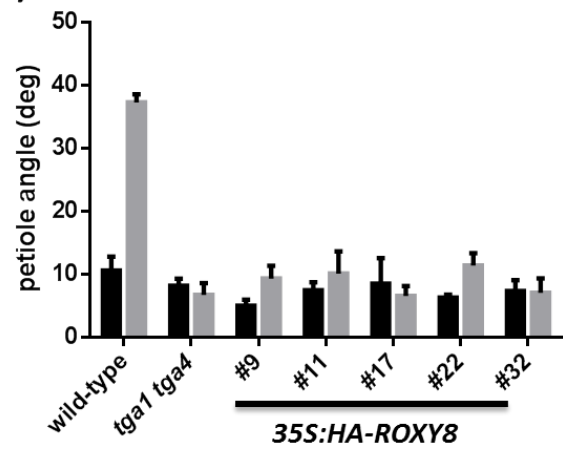

(C)

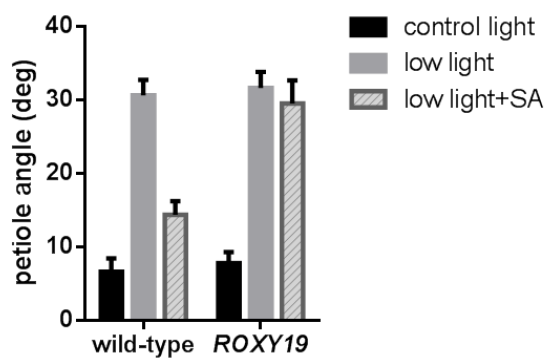

(B)

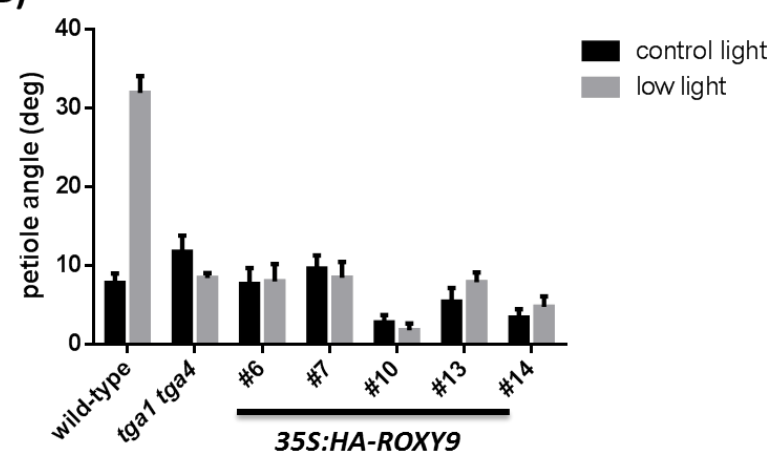

Figure 3.9 Overexpression of ROXY8 or ROXY9 phenocopies the tga1 tga4 phenotype.

Effect of low light treatment (reduction in light intensity from 100-120 to $15-20 \mu \mathrm{mol} \mathrm{m}^{-2} \mathrm{~s}^{-1}$ ) on the hyponastic growth of wild-type, tga1 tga4, and independent transgenic lines expressing either ROXY8 (A), ROXY9 (B) or ROXY19 (C) under the control of the CaMV 355 promoter. All proteins were fused to an HA-tag. See Figure legend 3.2 for details of plant growth and leaf angle measurements. Bars represent the average \pm SEM of 3 (ROXY8), 9 (ROXY9) or 6 plants (ROXY19). The images for petiole angle measurement are shown in Supplementary Figure S13 and Supplementary Figure S14. 


\subsection{The sequence of the C-terminal end of ROXY9 is not important for its repressive effect on hyponastic growth}

Most of ROXYs contain a functionally important C-terminal ALWL motif, which recruits the transcriptional co-repressor TOPLESS (Uhrig et al., 2017). Only ROXYs possessing this motif complemented the phenotype of roxy1 (Li et al., 2009). Likewise, only ROXYs with this motif can repress the expression of TGA2-dependent target promoters (Zander et al., 2012). In contrast, ROXY8 and ROXY9 belong to a clade of ROXYs that do not encode the conserved ALWL motif at the very C-terminal end. Instead, ROXY9 contains a SILY motif (Figure 3.10A).

(A)

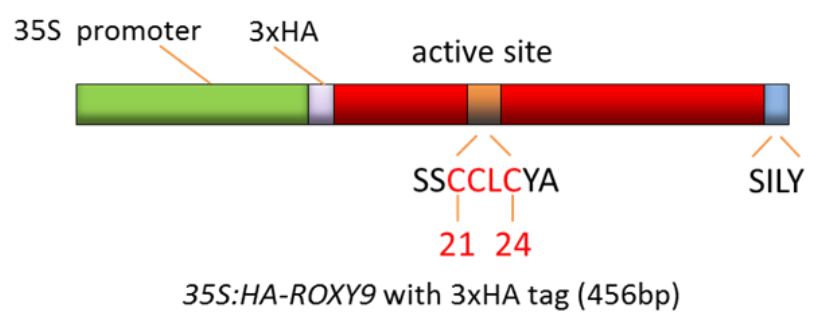

(B)

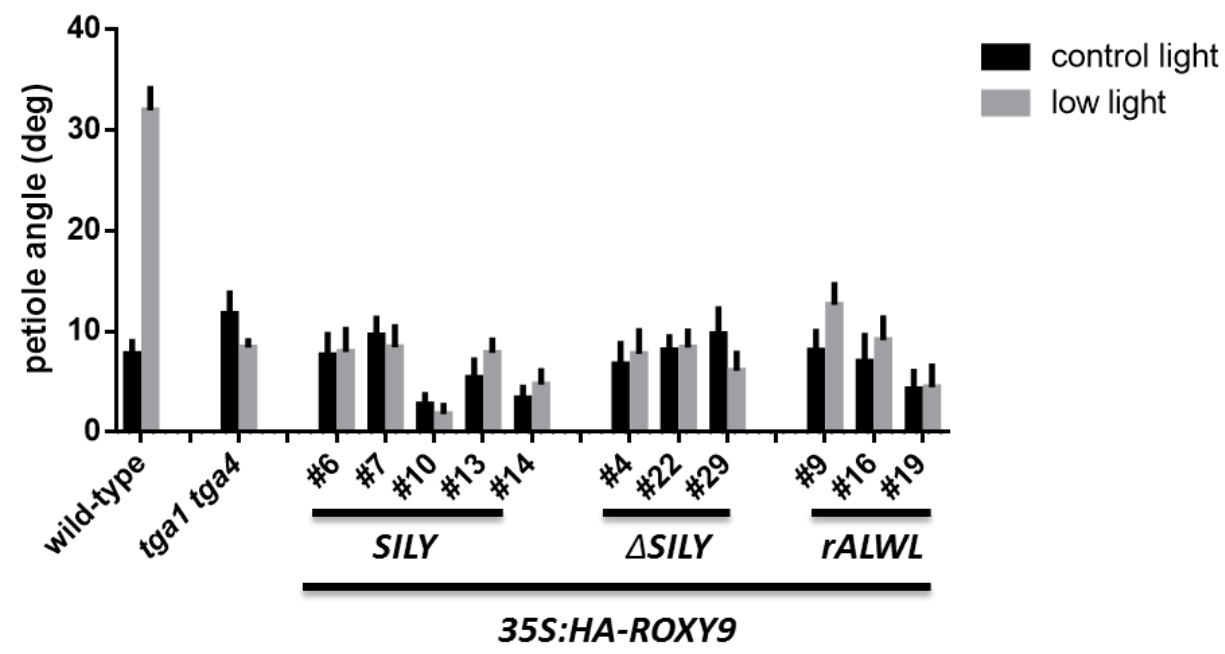

Figure 3.10 The sequence of the C-terminal end of ROXY9 is not important for its repressive effect on hyponastic growth.

Effect of low light treatment (reduction in light intensity from 100-120 to $15-20 \mu \mathrm{mol} \mathrm{m}^{-2} \mathrm{~s}^{-1}$ ) on the hyponastic growth of wild-type, tga1 tga4, and independent transgenic lines expressing either ROXY9, ROXY9 lacking the SILY (ROXY9( $\triangle S I L Y)$ ) motif and ROXY9 encoding an ALWL motif instead of the SILY motif (ROXY9(rALWL)) under the control of the CaMV 355 promoter. All proteins were fused to an HA-tag. See Figure legend 3.2 for details of plant growth and leaf angle measurements. Bars represent the average \pm SEM 9 plants of each transgenic line. 
In order to analyse the role of the C-terminal end of ROXY9, we either deleted it (35S:HA-ROXY9ASILY) or replaced it by the ALWL motif (35S:HA-ROXY9rALWL). Independent lines carrying these constructs showed impaired hyponastic growth as observed for 35S:HA-ROXY9 lines after transfer to low light intensities. Since the SILY motif is not present in ROXY8, the results obtained with the 35S:HA-ROXY9 $\Delta$ SILY were expected. Importantly, we can conclude that the ALWL motif does not interfere with the repressive function of ROXY9 (Figure 3.10B).

\subsection{The sequence of CCLC motif in the active center of ROXY9 is important for its repressive effect on hyponastic growth}

Next, we characterized the importance of the CCLC motif in the active center (Figure 3.11) which is slightly different from the CCMC/S motif found in most ROXYs. We introduced single point mutations individually for all the three cysteines and expressed these proteins under the CaMV 355 promoter in wild-type plants. In addition, a mutant was constructed in which all three cysteines were replaced by alanine residues. Western blot analysis was performed to identify transgenic lines with similar expression levels (Figure 3.11A). For comparison, extracts from plants with functional ROXY9 (ROXY9, ROXY9( $\triangle S I L Y)$, ROXY9(rALWL)) were loaded. Four independent lines of the ROXY9(SCLC) mutant, where the first cysteine was mutated, expressed similar amounts of the protein as transgenic lines expression ROXY9. Comparison of these plants after transfer to low light revealed that the ROXY9(SCLC) mutant protein did not repress hyponastic growth indicating that the first cysteine is important for its function (Figure 3.11B). The same effect was observed for four independent 35S:HA-ROXY9(CSLC) lines, although protein levels were as high as in those plants that encode the repressive $\operatorname{ROXY}(\triangle S I L Y)$ and $R O X Y(r A L W L)$ mutants. This result underpins the importance of the conserved second cysteine. In contrast, ROXY9(CSLS), in which the third cysteine was mutated, was functional. As expected, ROXY9(AALA) is not functional. 
(A)
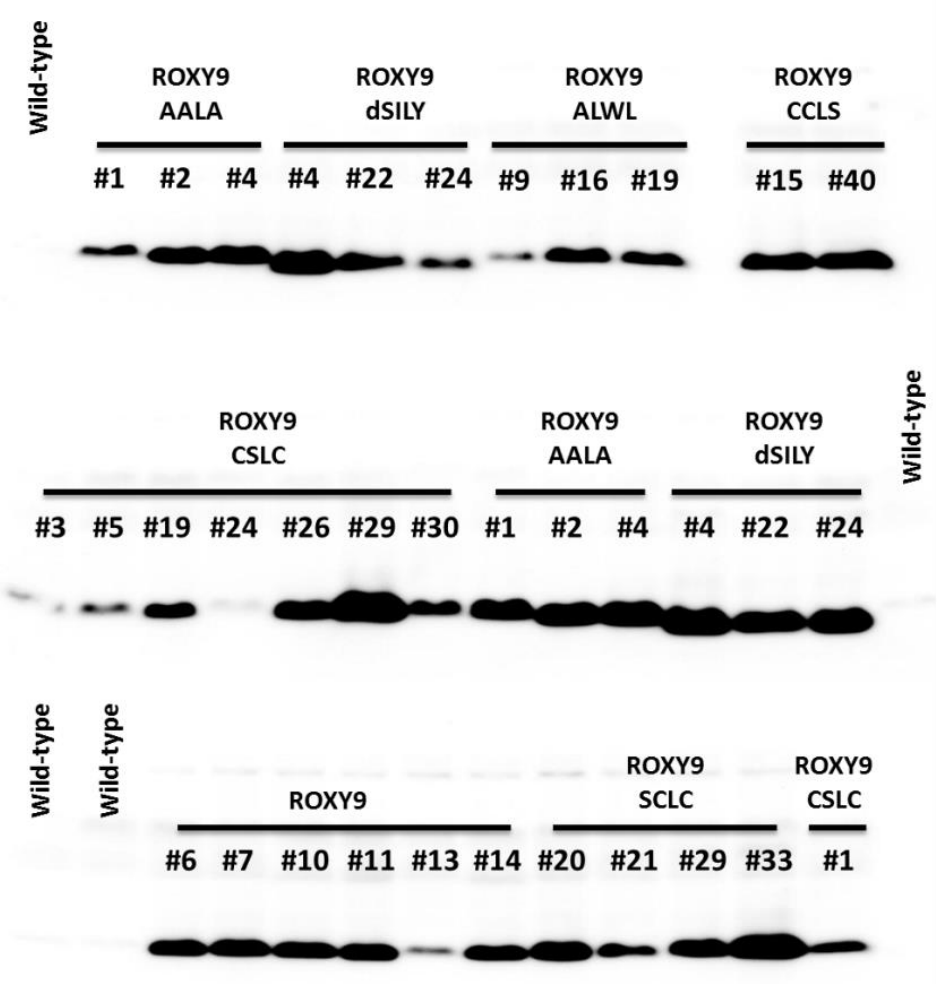

(B)

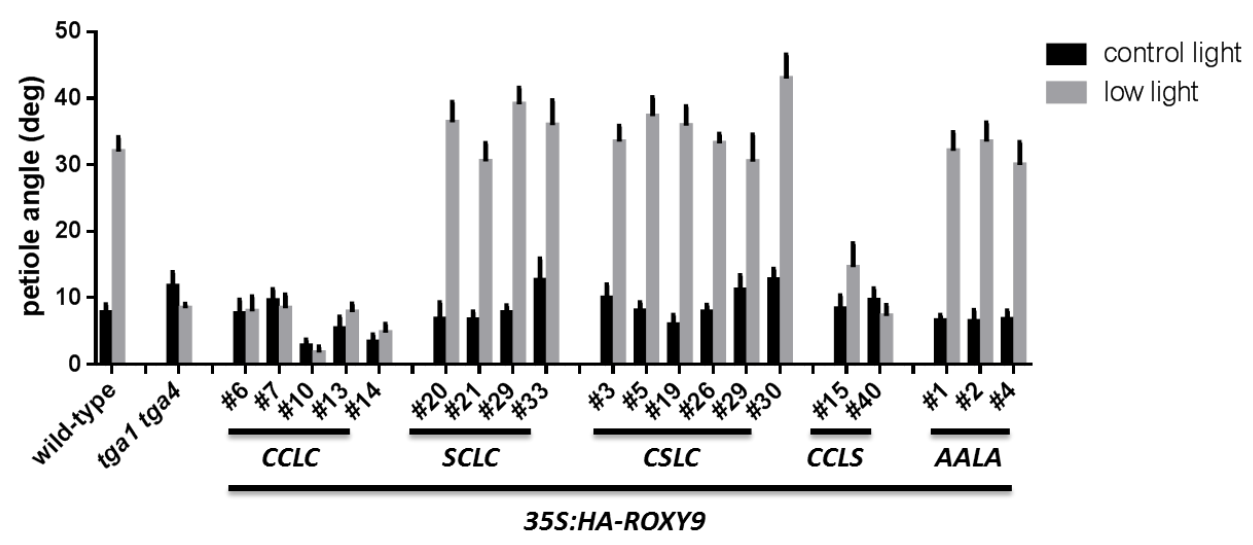

Figure 3.11 The sequence of CCLC motif in the active center of ROXY9 is important for its repressive effect on hyponastic growth.

(A) Western blot analysis of transgenic lines expressing HA-tagged ROXY9 and the indicated mutant versions of ROXY9 under the control of the CaMV35S promoter.

(B) Effect of low light treatment (reduction in light intensity from 100-120 to $15-20 \mu \mathrm{mol} \mathrm{m}^{-2} \mathrm{~s}^{-1}$ ) on the hyponastic growth of wild-type, tga1 tga4, and independent transgenic lines expressing either ROXY9 or ROXY9 mutants within the active site under the control of the CaMV 355 promoter. All proteins were fused to an HA-tag. See Figure legend 3.2 for details of plant growth and leaf angle measurements. Bars represent the average \pm SEM 9 plants of each transgenic line. 


\subsection{The roxy9 CRISPR-Cas9 mutant is not impaired in hyponastic}

growth

Due to lack of T-DNA insertion lines, roxy9 CRISPR-Cas9 mutants were generated by Florian Jung (Master thesis). Seven individual lines containing nucleotide deletions C-terminal to the CCLC active center resulting in frame shift mutations were identified and confirmed by sequence analysis. However, hyponastic growth and reversal of hyponastic growth was not different in these mutants as compared to wild-type.

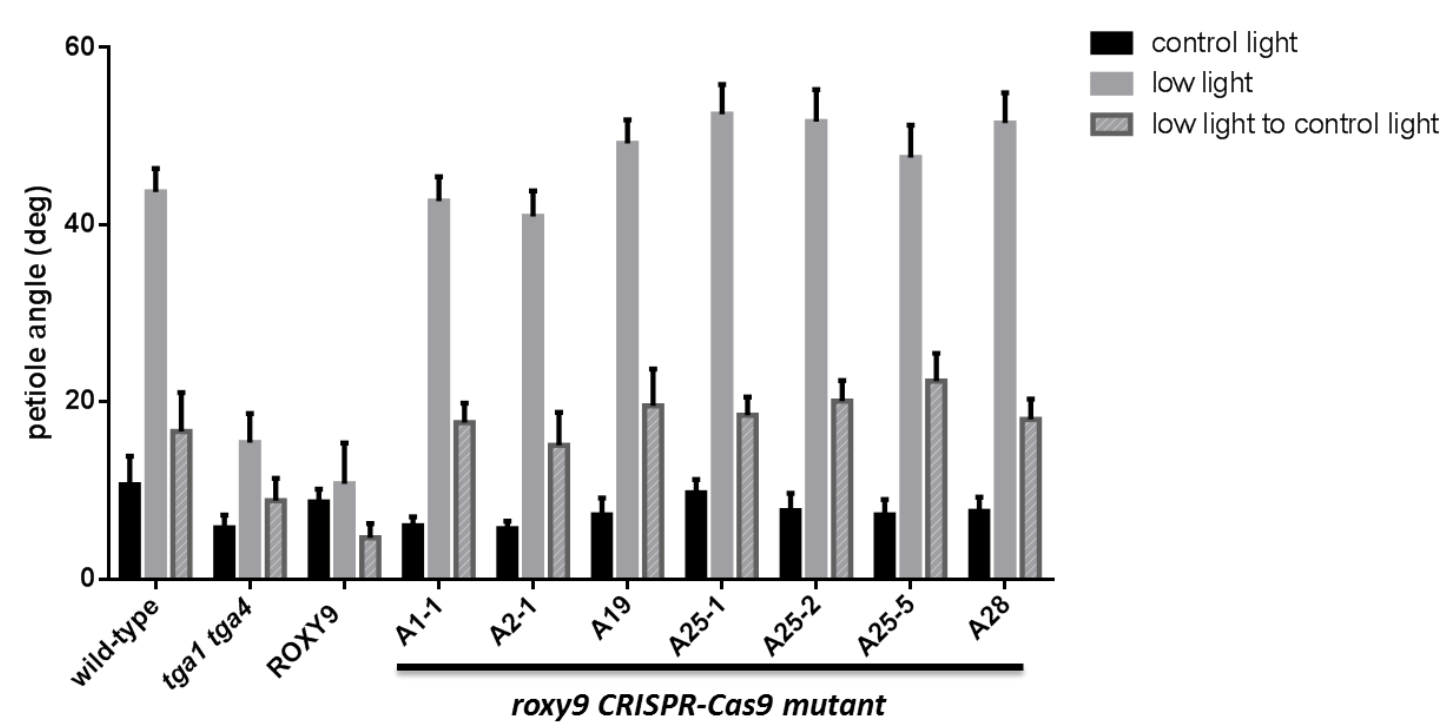

Figure 3.12 The roxy9 CRISPR-Cas9 mutant is not impaired in hyponastic growth.

Effect of low light treatment (reduction in light intensity from $100-120$ to $15-20 \mu \mathrm{mol} \mathrm{m}^{-2} \mathrm{~s}^{-1}$ ) and subsequent transfer to control light) on the hyponastic growth of wild-type, tga1 tga4, 35S:HA-ROXY9 and roxy9 CRISPR-Cas9 mutants. See Figure legend 3.2 and Figure 3.6A for details of plant growth, leaf angle measurements and light regime. Bars represent the average \pm SEM of 5 to 6 plants of each genotype. 


\subsection{The expression of over 150 low-light-induced genes correlates with hyponastic growth in wild-type, tga1 tga4 and 35S:HA-ROXY9 plants}

To identify potential target genes of TGA1 and TGA4, transcriptome analysis was performed with RNA from petioles of wild-type tga1 tga4 and 35S:HA-ROXY9 plants. Four-week-old plants were treated with low light (reduction in light intensity from 100-120 to $15-20 \mu \mathrm{mol} \mathrm{m}^{-2} \mathrm{~s}^{-1}$ ) for six hours and total RNA was isolated from petioles of 15 plants of each genotype and treatment. The experiment was repeated four times with batches of independently grown plants. Samples were used for ATH1 Affymetrix 1.0 ST gene chip analysis.

In order to get a first impression of the global structure of the dataset, we performed a principal component analysis (PCA) which typically results in clusters of samples with a similar expression pattern (Figure 3.13). The samples from wild-type and tga1 tga4 plants grown under control light and under low light showed a clear separation indicating that the transcriptomes of both genotypes are different and that they both respond to the low light treatment. In contrast, the clusters representing the tga1 tga4 mutant and the 35S:HA-ROXY9 plants grown under low light overlapped. These results provide evidence that ROXY9 and TGA1 and TGA4 regulate a similar set of genes. 


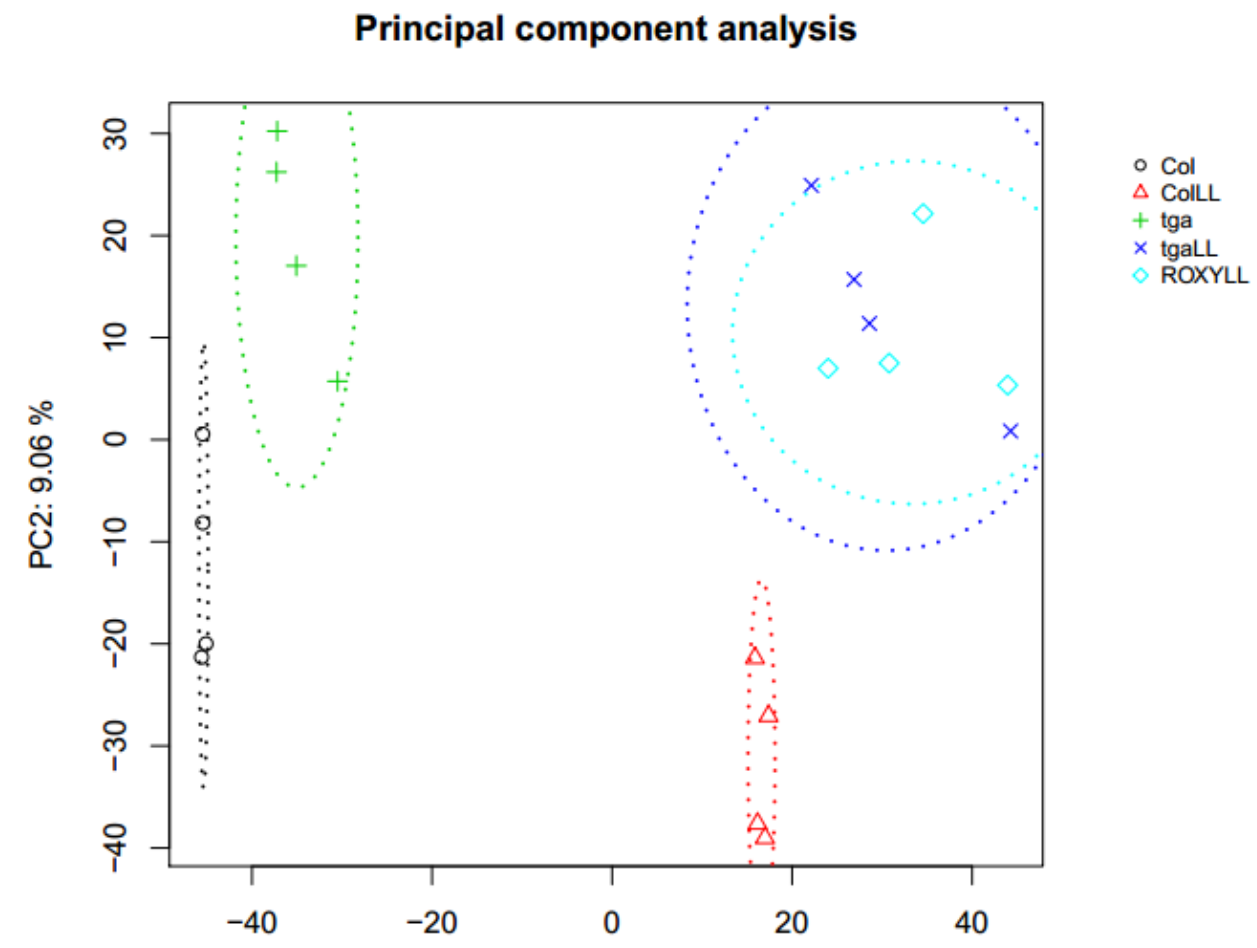

PC1: $24.16 \%$

Figure 3.13 TGA1/TGA4 and ROXY9 regulate an overlapping set of genes.

Principal component analysis of the normalized transcriptome data obtained from hybridization of ATH1 Affymetrix 1.0 ST microarrays. Symbols: $O, \Delta,+, X$ and $\Delta$, represent four biological replicates of Col-0 grown at 100-120 $\mu \mathrm{mol} \mathrm{m}^{-2} \mathrm{~s}^{-1}$, Col-0 grown for $6 \mathrm{~h}$ at $15-20 \mu \mathrm{mol} \mathrm{m}^{-2} \mathrm{~s}^{-1}$ (LL), tga1 tga4 grown at 100-120 $\mu \mathrm{mol} \mathrm{m} \mathrm{s}^{-2}$, tga1 tga4 transferred for $6 \mathrm{~h}$ to $15-20 \mu \mathrm{mol} \mathrm{m}^{-2} \mathrm{~s}^{-1}$ (LL) and 35S:HA-ROXY9 plants transferred for $6 \mathrm{~h}$ to $15-20 \mu \mathrm{mol} \mathrm{m}^{-2} \mathrm{~s}^{-1}$ (LL).

To visualize and cluster the relative transcript levels of all those genes that are differentially expressed in wild-type plants depending on the light conditions (fold change $(\log F C)<-1$ or $>1, p<0.05)$ and those that are differentially expressed in at least one the two other genotypes as compared to Col-0 (fold change $(\operatorname{logFC})<-0.87$ or $>0.87, p<0.05$ ), we applied the MarVis software (Kaever et al., 2009) (Figure 3.14). This program groups genes with similar relative expression levels into cluster and color-codes the relative expression levels in the five samples. We first focused on cluster 5, which contains 167 genes that are induced by low light in Col-0 but not in tga1 tga4 and 35S:HA-ROXY9 plants. 

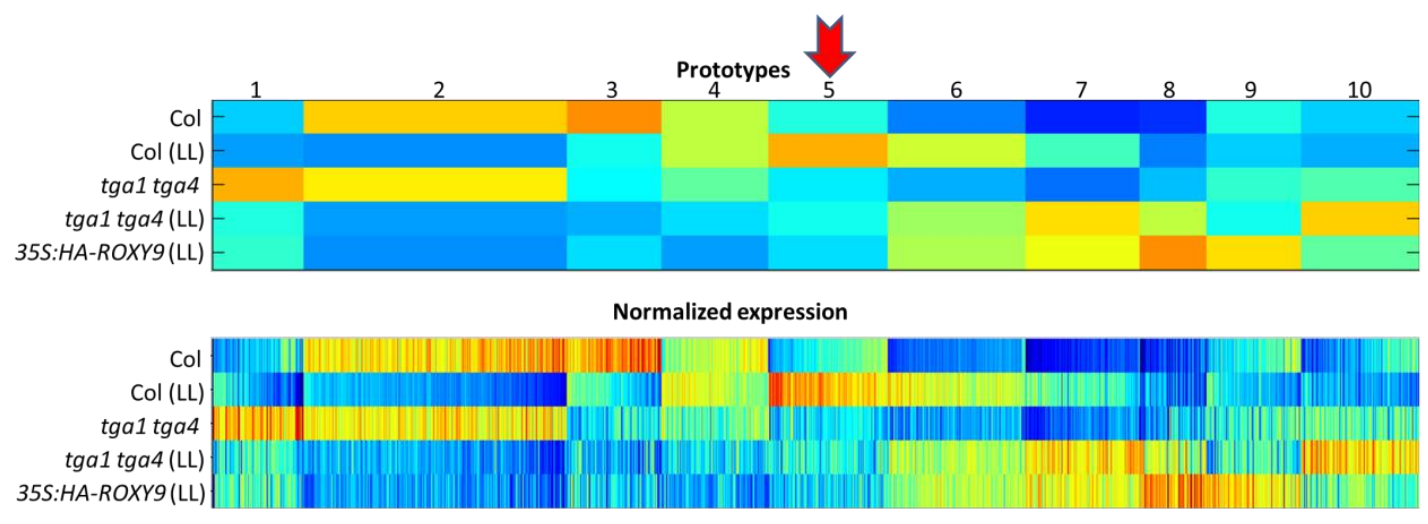

tga1 tga4 (LL) (35s.
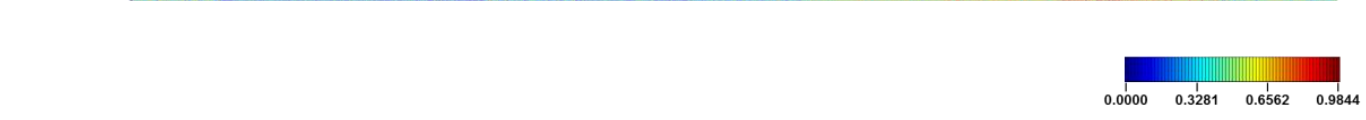

Figure 3.14 MarVis analysis leads to the identification of genes that correlate with hyponastic growth.

Clustering of 1716 genes differentially expressed in at least of the five samples. Genes were clustered into 10 prototypes according to their normalized expression pattern using the MarVis software (upper panel). The width of each prototype column is proportional to the number of genes assigned to this prototype. The lower panel shows the normalized expression profiles of the individual transcripts. The program color codes the relative expression of a given prototype (upper panel) or transcript (lower panel) in the different samples. Red depicts the highest relative expression, blue the lowest (see color scale). Col: Col-0 grown at 100-120 $\mu \mathrm{mol} \mathrm{m}^{-2} \mathrm{~s}^{-1}$, Col (LL): Col-0 transferred for $6 \mathrm{~h}$ to $15-20 \mu \mathrm{mol} \mathrm{m} \mathrm{s}^{-1}$; tga1 tga4: tga1 tga4 grown at 100-120 $\mu \mathrm{mol} \mathrm{m}{ }^{-2}$ $\mathrm{s}^{-1}$; tga1 tga4 (LL): tga1 tga4 transferred for $6 \mathrm{~h}$ to $15-20 \mu \mathrm{mol} \mathrm{m} \mathrm{m}^{-2} \mathrm{~s}^{-1} ; 35 \mathrm{~s}$ :HA-ROXY9 (LL): 35S:HA-ROXY9 plants transferred for $6 \mathrm{~h}$ to $15-20 \mu \mathrm{mol} \mathrm{m} \mathrm{s}^{-2} \mathrm{~s}^{-1}$ for $6 \mathrm{~h}$.

Gene Ontology (GO) over-representation analysis supported the notion that these genes are involved in hyponastic growth. Genes grouped into the GO terms "cell "growth" were enriched. Consistent with the notion that auxin stimulates cell expansion, genes belonging to the GO term "response to auxin" were enriched as well. 


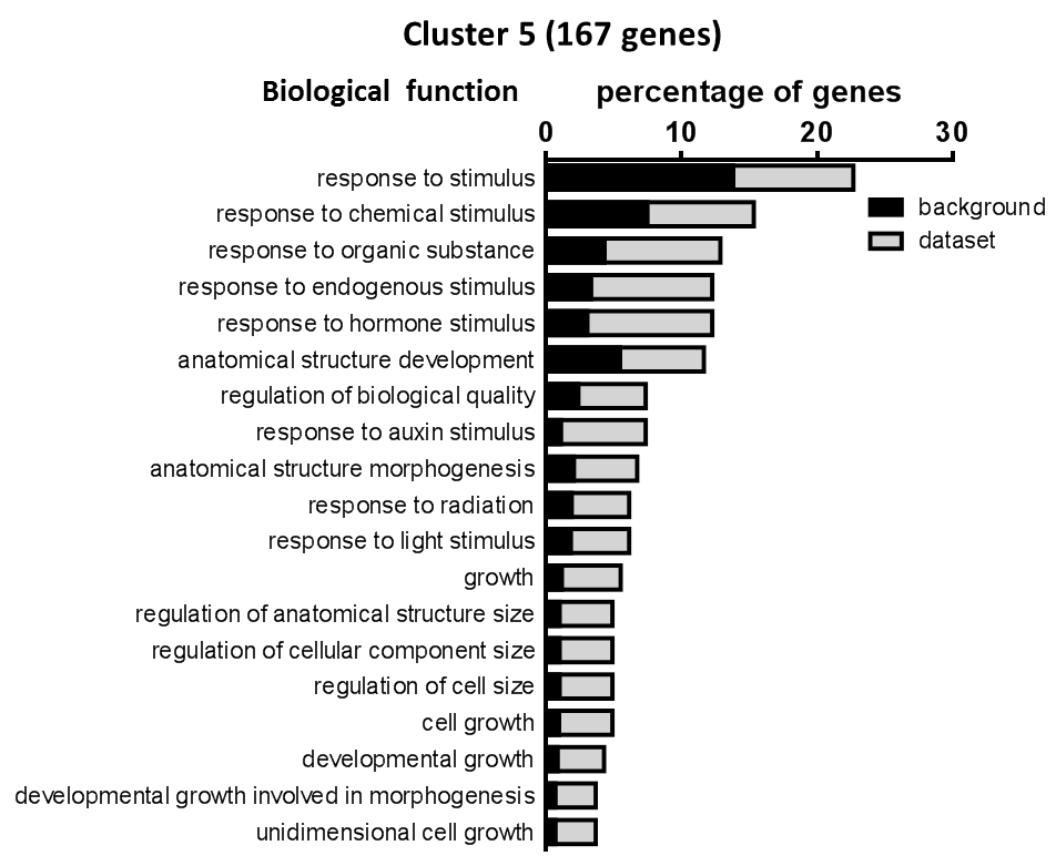

Figure 3.15 GO term analysis of genes whose expression correlates with the phenotype of wild-type, tga1 tga4 and 35S:HA-ROXY9 plants.

167 genes which show low-light induced expression in wild-type but not in tga1 tga4 and 35S:HA-ROXY9 plants (cluster 5) were subjected to Gene Ontology (GO) overrepresentation analysis. Black bars indicate the percentage of genes of each $\mathrm{GO}$ term found within the group of all annotated genes of the Arabidopsis genome. Gray bars indicate the percentage of genes of each GO term found within the group of genes that are induced by low light in Col-0 but not in tga1 tga4 and 35S:HA-ROXY9 plants.

Next, we confirmed the expression data obtained from the four independent experiments analysed by microarray analysis. A fifth independent experiment was performed and the RNA was subjected to qRT-PCR analysis using primers detecting the transcripts of XTH8 (xyloglucanendotransglucosylase/hydrolase 8, proposed to be related with promoting cell expansion) and IAA19 (indole-3-acetic acid inducible 19, a primary auxin-responsive gene). The expression of both genes was induced nearly 2-fold in wild-type; in contrast, no induction was observed in the tga1 tga4 background, which is consistent with the microarray results (Figure 3.16A). In addition, we examined whether the expression of TGA1/TGA4-regulated genes would be reduced after transfer of low light-treated plants to control conditions. As shown in Figure 3.16B, induction upon low light treatment was stronger than in the experiment shown in Figure 3.16A, which is due to the longer exposure to low light (10.5 $\mathrm{h}$ during the first period and 7.5 hours during the second photoperiod as 
opposed to $6 \mathrm{~h}$ ). Under these conditions, XTH8 and IAA19 were also induced in the tga1 tga4 mutant, although less efficiently than in wild-type plants. In both genotypes, gene expression was reverted to background levels after the transfer of plants to control light conditions. A similar pattern was observed for XTH33, expansin EXPA11, and the inodole-3-acidic acid-amido synthetase GH3.6.

(A)
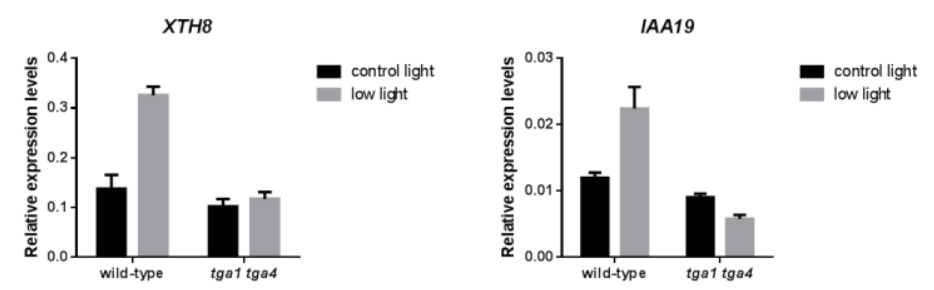

(B)
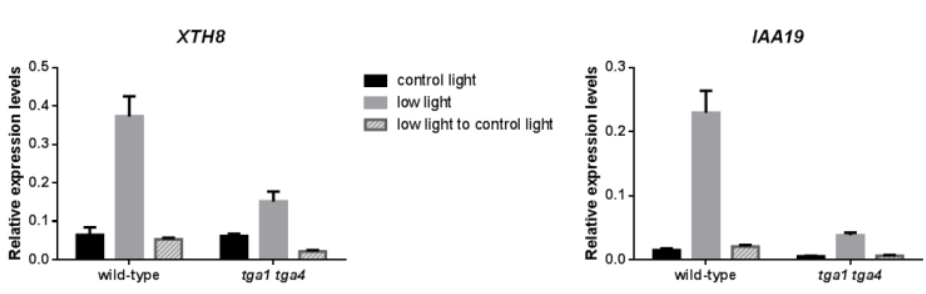

XTH33

GH3.6
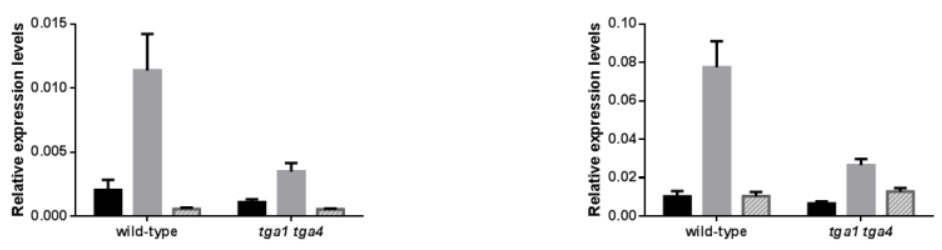

EXPA11

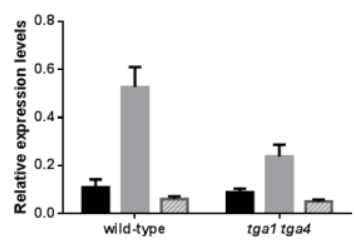

Figure 3.16 The expression of genes related to cell growth and response to auxin correlates with hyponastic growth.

(A) qRT-PCR analysis of XTH8 and IAA19 expression in wild-type and tga1 tga4 after low light treatment. Four-week-old soil-grown wild-type and tga1 tga4 were treated with low light for 6 hours (reduction in light intensity from 100-120 to $15-20 \mu \mathrm{mol} \mathrm{m} \mathrm{m}^{-2} \mathrm{~s}^{-1}$ ). Transcript levels were normalized to the transcript level of UBQ5. Bars represent the average \pm SEM of four biological replicates, each with dissected petioles from five independent plants.

(B) qRT-PCR analysis of light-induced genes in wild-type and tga1 tga4 after transfer of plants from low light to control light conditions (see Figure 3.6A for the light regime). Transcript levels were normalized to the transcript level of UBQ5. Bars represent the average \pm SEM of five biological replicates, each with dissected petioles from five independent plants. 


\subsection{Petioles of tga1 tga4 and 35S:HA-ROXY9 plants are shorter than wild-type petioles}

Since petioles show hyponastic growth in the dark, we assume that genes found in cluster 5 are induced during the dark period at the abaxial side of the petioles, whereas a different set of genes is induced under control light conditions on the adaxial side. This alternating growth habit would contribute to petiole length under a normal dark/light photoperiod. Since genes for hyponastic growth are less expressed in tga1 tga4 and 35S:HA-ROXY9 plants we expected that their petioles should be shorter. Indeed, petiole length was reduced by $25 \%$ in the tga1 tga 4 mutant and by 50\% in independent 35S:HA-ROXY9 plants (Figure 3.17).

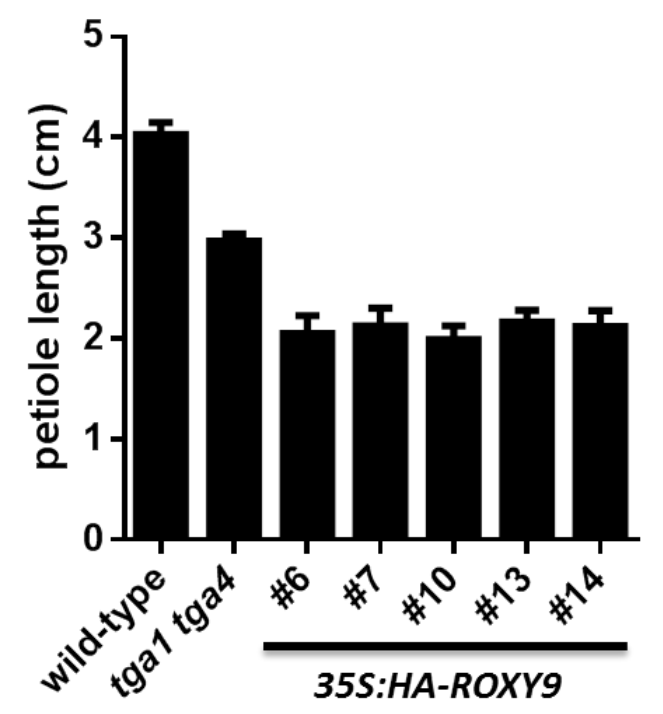

Figure 3.17 Petioles of tga1 tga4 and 35S:HA-ROXY9 plants are shorter than wild-type petioles. Plants of the indicated genotypes were grown for four weeks under a 12/12 light/dark rhythm and the length of the petioles was measured using Image $J$ analysis of photographs. Bars represent the average \pm SEM of five biological replicates, each with a petiole of leaf number 7 to 8. 


\subsection{Genes with putative oxidoreductase activities are more highly expressed in tga1 tga4 and 35S:HA-ROXY9 plants than in wild-type}

Next, we focused on those genes that are differentially expressed in wild-type, tga1 tga4 and 35S:HA-ROXY9 plants under low light, without taking into consideration whether they are regulated by light or not. Again, the relative transcript levels of all those genes that are differentially expressed in Col-0 plants depending on the light conditions (fold change $(\log F C)<-1$ or $>1, p<0.05)$ and those that are differentially expressed in at least one the two other genotypes as compared to Col-0 (fold change $(\log F C)<-0.87$ or $>0.87, p<0.05)$ were analysed with the MarVis software; but this time, only the expression data of the three low-light treated genotypes were considered (Figure 3.18).

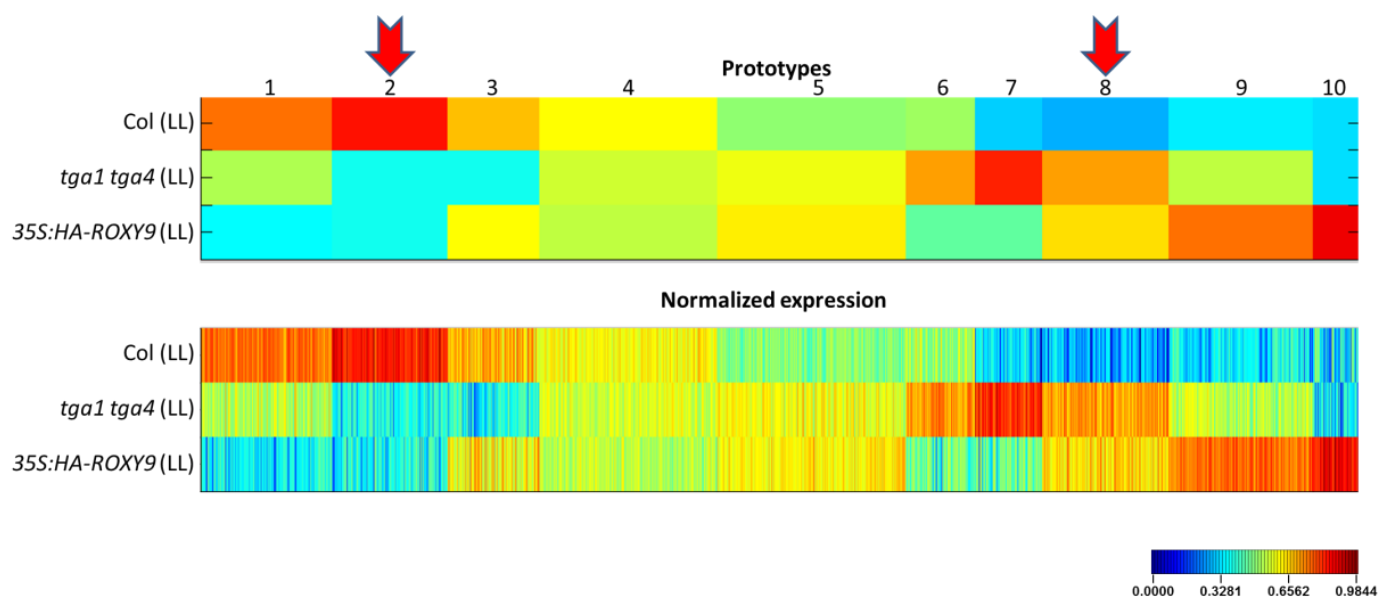

Figure 3.18 MarVis analysis leads to the identification of genes that correlate with hyponastic growth.

Clustering of 1716 genes differentially expressed in at least of the five samples analysed in Figure 3.18. Genes were clustered into 10 prototypes according to their normalized expression pattern using the MarVis software (upper panel). The width of each prototype column is proportional to the number of genes assigned to this prototype. The lower panel shows the normalized expression profiles of the individual transcripts. The program color codes the relative expression of a given prototype (upper panel) or transcript (lower panel) in the different samples. Red depicts the highest relative expression, blue the lowest (see color scale). The indicated genotypes were first grown at $100-120 \mu \mathrm{mol} \mathrm{m}^{-2} \mathrm{~s}^{-1}$ and subsequently transferred for $6 \mathrm{~h}$ to $15-20 \mu \mathrm{mol} \mathrm{m}$ $s^{-1}$.

Cluster 2 contains genes that are less expressed in tga1 tga4 and 35S:HA-ROXY9 plants and partially overlaps with cluster 5 discussed above (Figure 3.19B). GO term 
analysis (Figure 3.19A) revealed an over-representation of genes belonging to the GO term "response to auxin".

Genes, which might represent repressors of hyponastic growth are represented in cluster 8 , which partially overlaps with cluster 8 in the analysis shown in Figure 3.19B. Apparently, these genes are only slightly affected by light. Importantly, GO-term analysis revealed a strong enrichment of genes with oxidoreductase activities within the domain "molecular function" and of genes related to "response to jasmonic acid stimulus" and "cell redox homeostasis".

(A)

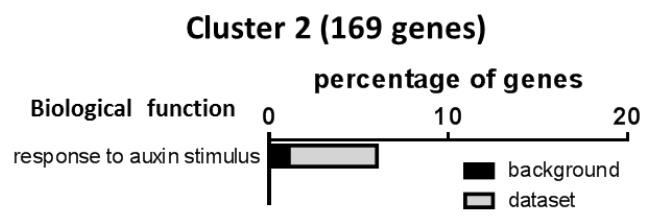

(B)

Cluster 8 (175 genes)

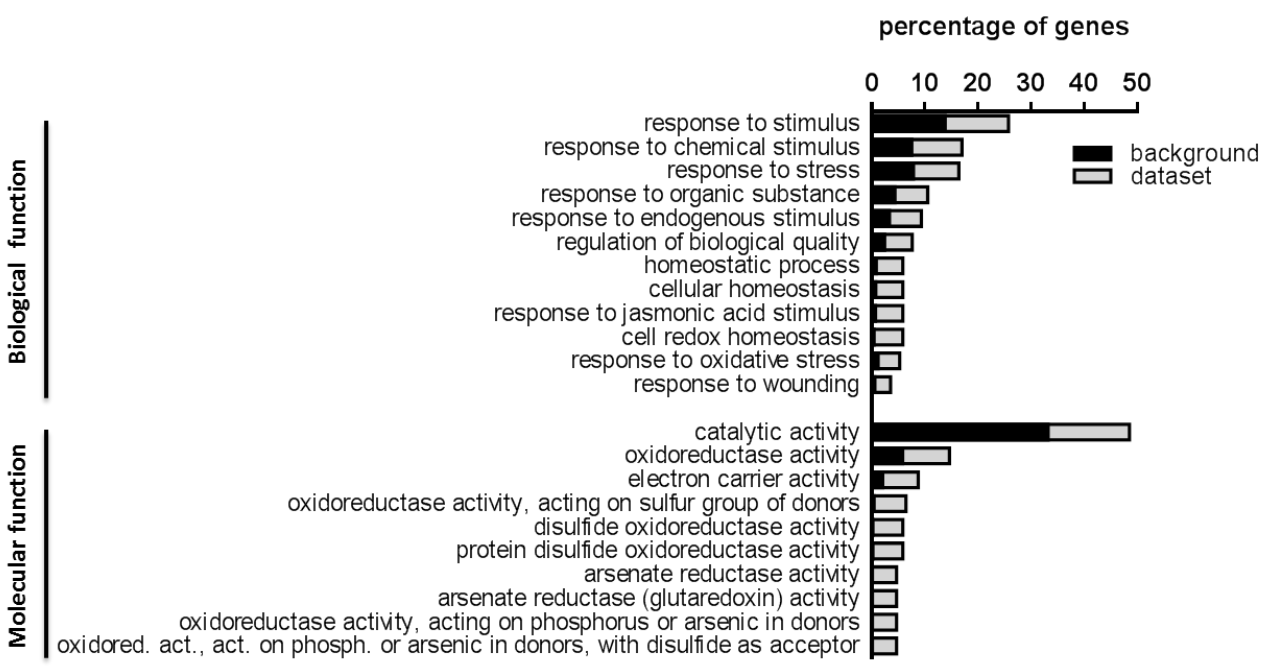

Figure 3.19 GO term analysis of genes whose expression correlates with the phenotype of wild-type, tga1 tga4 and 35S:HA-ROXY9 plants.

(A) 169 genes which show higher expression in low light-treated wild-type than in low light-treated tga1 tga4 and 35S:HA-ROXY9 plants were subjected to Gene Ontology (GO) overrepresentation analysis.

(B) 175 genes which show lower expression in low light-treated wild-type than in low light-treated tga1 tga4 and 35S:HA-ROXY9 plants were subjected to Gene Ontology (GO) overrepresentation analysis.

Black bars indicate the percentage of genes of each GO term found within the group of all annotated genes of the Arabidopsis genome. Gray bars indicate the percentage of genes of each $\mathrm{GO}$ term found within the group of differentially regulated as indicated in (A) and (B). 
Closer inspection of the list of genes that are higher expressed in tga1 tga4 and 35S:HA-ROXY9 plants than in wild-type plants revealed that ROXY11 to ROXY15 represent the most-highly up-regulated genes (32-fold for ROXY13 to 6.4-fold for ROXY15 in tga1 tga4). These 5 genes are part of a gene cluster that seems to be co-regulated. In addition, ROXY3, ROXY4, ROXY18, ROXY10 and ROXY17 are constitutively higher expressed in in tga1 tga4 and 35S:HA-ROXY9 plants than in wild-type plants. qRT-PCR analysis of RNA from independently grown tga1 tga4 and 35S:HA-ROXY9 plants confirmed and extended this result (Figure 3.20).
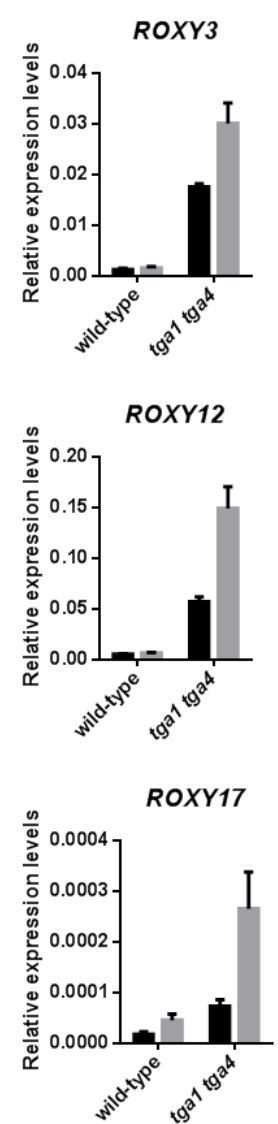
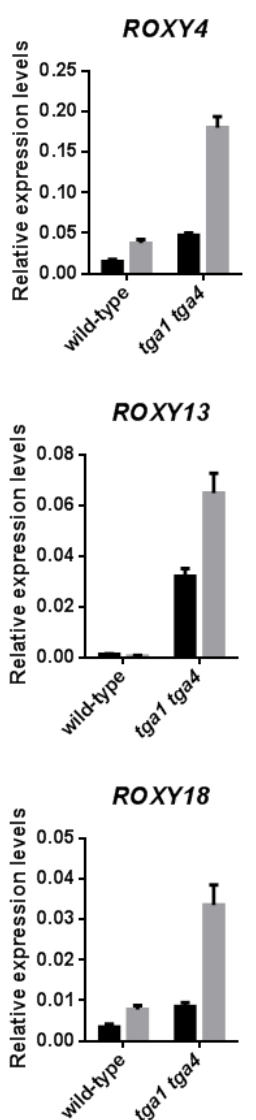
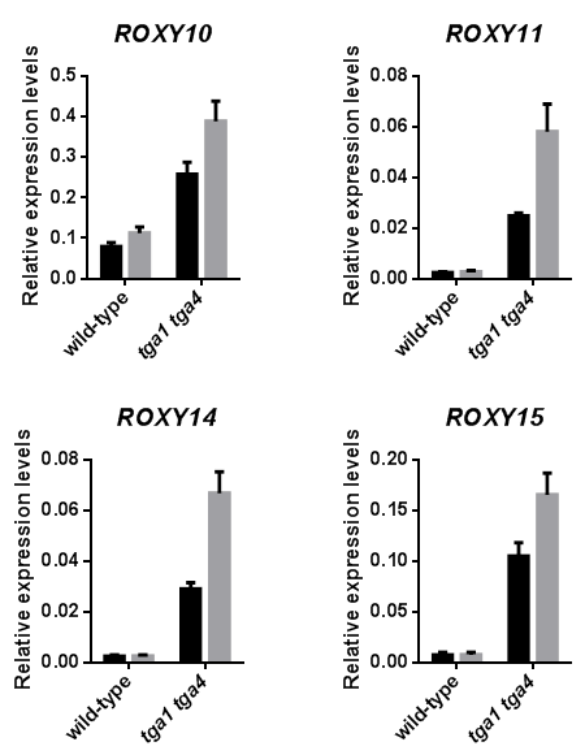

Figure 3.20 Expression of CC-type glutaredoxins in wild-type and tga1 tga4.

qRT-PCR analysis of CC-type glutaredoxins in wild-type and tga1 tga4 after low light treatment. Four-week-old soil-grown wild-type and tga1 tga4 were treated with low light for 6 hours (reduction in light intensity from 100-120 to $15-20 \mu \mathrm{mol} \mathrm{m-2} \mathrm{s-1).} \mathrm{Transcript} \mathrm{levels} \mathrm{were}$ normalized to the transcript level of UBQ5. Bars represent the average \pm SEM of four biological replicates, each with dissected petioles from five independent plants. 
Transcription factor SHYG (SPEEDY HYPONASTIC GROWTH; ANAC047) is also highly expressed in tga1 tga4 and 35S:HA-ROXY9 plants (Figure 3.21A). This result was unexpected, since overexpression of SHYG enhances the hyponastic response in response to waterlogging, whereas hyponastic petiole growth is clearly impaired in two shyg T-DNA insertion mutants shyg-1 and shyg-2 (Rauf et al., 2013). Although elevated expression of SHYG in the tga1 tga4 mutant was not sufficient to promote hyponastic growth, we tested, whether SHYG plays a role in low light-induced hyponastic growth. However, the response was unaffected as indicated by the wild-type-like petiole angles in 35S:SHYG and in shyg-1 and shyg-2 mutant plants (Figure 3.21B). It is concluded that SHYG cannot influence hyponastic growth under our experimental conditions.
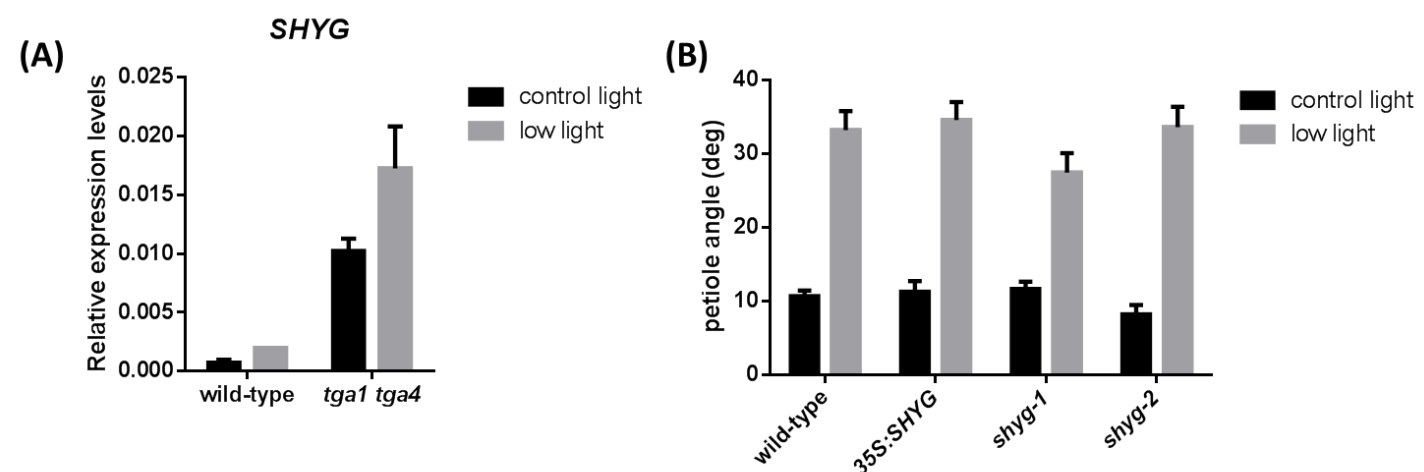

Figure 3.21 SHYG are not important for the regulation of hyponastic growth.

(A) qRT-PCR analysis of SHYG expression in wild-type and tga1 tga4 after low light treatment. Four-week-old soil-grown wild-type and tga1 tga4 were treated with low light for 6 hours (reduction in light intensity from 100-120 to $15-20 \mu \mathrm{mol} \mathrm{m}^{-2} \mathrm{~s}^{-1}$ ). Transcript levels were normalized to the transcript level of UBQ5. Bars represent the average \pm SEM of four biological replicates, each with dissected petioles from five independent plants.

(B) Effect of low light treatment (reduction in light intensity from 100-120 to $15-20 \mu \mathrm{mol} \mathrm{m}^{-2} \mathrm{~s}^{-1}$ ) on the hyponastic growth of wild-type and tga1 tga4. See Figure legend 3.2 for details of plant growth and leaf angle measurements. Bars represent the average \pm SEM 9 plants of each transgenic line. 


\subsection{Motif mapper analysis suggests that TGA1 and TGA4 are negative regulators of gene expression}

To identify transcription factor binding motifs in the promoters of the different gene clusters as defined in Figure 3.14 and 3.18, we scanned 1-kb sequences upstream of the predicted transcriptional start sites using the Motif Mapper cis element analysis tool (Berendzen et al., 2012) (Table 3.1). The program compares the average number of specific binding sites in a given group of genes that was randomly chosen (1000 times) from the whole genome and compares this number with the actual number of binding sites within a specific group of genes. The binding site of TGA transcription factors (TGACGT) was 1.6-fold more frequent in the group of 175 genes that are higher expressed in tga1 tga4 and 35S:HA-ROXY9 plants than in 167 randomly chosen genes from the genome. The motif TGACGTGG was even more enriched (2.1 fold). If these genes would be the direct target genes of TGA1 and TGA4, TGA1 and TGA4 would be repressors of gene expression. Target genes would repress genes involved in hyponastic growth. Promoters that control the group of 167 genes that positively correlates with hyponastic growth (cluster 5 in Figure 3.16) contain a light regulatory motif, which is plausible because these genes are induced by low light. In addition, the CACATG motif, which is recognized by bHLH transcription factor MYC2 and potentially other bHLH transcription factors as well, is enriched by a factor of 1.64. Moreover, a RY motif, which is recognized by B3 transcription factors is enriched by a factor of 1.76 . These motifs might be recognized by the repressive transcription factors that are up-regulated in tga 1 tga 4 and 35S:HA-ROXY9 plants. 
Table 3.1 Promoter elements enriched in co-regulated genes

\begin{tabular}{|ccccc|} 
Cluster 5 (167 genes) & $\begin{array}{c}\text { 167 genes in } \\
\text { cluster 5 } \\
\text { Total Motifs }\end{array}$ & $\begin{array}{c}\text { Average } \\
\text { selection } \\
\text { Total Motifs }\end{array}$ & p-value & Ratio: total motifs \\
\hline CACATG/CATGTG & 135 & 82.585 & 0 & 1.635 \\
CATGCATG (RY motif) & 10 & 5.68 & 0.0401 & 1.761 \\
CATGCA/TGCATG (RY motif, B3) & 95 & 76.713 & 0.0336 & 1.238 \\
\hline ACGTGGC/GCCACGT (ABRE) & 0 & 2.748 & -0.0475 & 0.000 \\
TGTATATAT/ATATATACA (light regulatory motif) & 30 & 18.533 & 0.004 & 1.619 \\
\hline
\end{tabular}

Cluster 2 (169 genes)

\begin{tabular}{|ccccc|}
\hline Motifs & $\begin{array}{c}\text { 169 genes in } \\
\text { cluster } 2 \\
\text { Total Motifs }\end{array}$ & $\begin{array}{c}\text { Average } \\
\text { selection } \\
\text { Total Motifs }\end{array}$ & p-value & Ratio: total motifs \\
\hline CACATG/CATGTG & 138 & 83.95 & 0 & 1.644 \\
\hline CACGTA/TACGTG (G-Box, bZIP) & 51 & 38.656 & 0.0329 & 1.319 \\
\hline CATGCA/TGCATG (RY motif, B3) & 105 & 77.681 & 0.004 & 1.352 \\
\hline TGTATATAT/ATATATACA (light regulatory motif) & 36 & 18.703 & 0.0001 & 1.925 \\
\hline
\end{tabular}

Cluster 8 (175 genes)

\begin{tabular}{|c|c|c|c|c|}
\hline & $\begin{array}{l}175 \text { genes in } \\
\text { cluster } 8\end{array}$ & $\begin{array}{l}\text { Average } \\
\text { selection }\end{array}$ & & \\
\hline Motif & Total Motifs & Total Motifs & $\mathrm{p}$-value & Ratio: total motifs \\
\hline TGACGT/ACGTCA & 76 & 47.345 & 0.0001 & 1.605 \\
\hline TGACG/CGTCA & 203 & 151.601 & 0 & 1.339 \\
\hline TGACGTGG/CCACGTCA & 12 & 5.591 & 0.0078 & 2.146 \\
\hline CACGTG & 54 & 32.281 & 0.0003 & 1.673 \\
\hline CACATG/CATGTG & 111 & 87.031 & 0.0113 & 1.275 \\
\hline CACGTA/TACGTG (G-Box, bZIP) & 66 & 40.202 & 0.0001 & 1.642 \\
\hline CATGCATG (RY motif) & 19 & 5.887 & 0 & 3.227 \\
\hline CATGCA/TGCATG (RY motif, B3) & 127 & 80.136 & 0 & 1.585 \\
\hline CATGCAT/ATGCATG (RY motif) & 69 & 34.147 & 0 & 2.021 \\
\hline CATGCAY/RTGCATG (RY motif) & 82 & 45.479 & 0 & 1.803 \\
\hline TAACGTA/TACGTTA (GA response) & 25 & 16.361 & 0.0222 & 1.528 \\
\hline TTACGT/ACGTAA (NAC) & 97 & 69.111 & 0.0022 & 1.404 \\
\hline TTACGTG/CACGTAA (NAC) & 23 & 13.692 & 0.0082 & 1.680 \\
\hline ACGTGGC/GCCACGT (ABRE) & 25 & 14.816 & 0.0062 & 1.687 \\
\hline YACGTGGC/GCCACGTR (ABRE) & 17 & 9.028 & 0.006 & 1.883 \\
\hline NGATAAGNMNN/NNKNCTTATCN (GATA) & 91 & 46.509 & 0 & 1.957 \\
\hline
\end{tabular}

The table depicts promoter elements enriched in the clusters resulting from MarVis analysis in Figure 3.15 (custer 5, induced by low light in wild-type but not in tga1 tga4 and 35S:HA-ROXY9) and Figure 3.19 (clusters 2 (higher expressed in low light-treated wild-type than in low light-treated tga1 tga4 and 35S:HA-ROXY9) and 8 (higher expressed in low light-treated tga1 tga4 and 35S:HA-ROXY9 than in low light-treated wild-type). Numbers represent the total amount of motifs within the set of promoters of one cluster and within randomly chosen sets of promoters from the whole genome. The occurrence of enriched motifs was determined in the 1-kb sequences upstream of the $5^{\prime}$-untranslated regions using Motif Mapper (Berendzen et al., 2012). 


\section{Discussion}

The bZIP protein TGA1a from tobacco was the first plant transcription factor to be identified by exploiting its binding activity to the activation sequence-1 of the Cauliflower Mosaic Virus 355 promoter (Katagiri et al. 1989; Lam et al. 1989). Later, it was discovered that its orthologues TGA1 and TGA4 are important for defense responses against biotrophic pathogens in Arabidopsis thaliana (Kersawani et al., 2007, Shearer et al., 2012). Two redox-active cysteines in the coding regions of TGA1 and TGA4 might be important to control the activity of the protein by the plant defense hormone salicylic acid (SA) (Despres et al., 2003). Moreover, TGA1 and TGA4 interact with ROXY-type glutaredoxins, which might catalyze the redox modification (Dr. Martin Muthreich PhD thesis). Here, we report that TGA1 and TGA4 are not only involved in defense responses, but also in the growth response hyponasty. Moreover, we suggest that TGA1 and TGA4 activity is regulated by ROXY9 and the potentially redundant ROXYs ROXY8 and ROXY21.

\subsection{TGA1 and TGA4 are connected to various signaling cascades that induce hyponastic growth}

TGA1 and TGA4 are required for hyponastic growth, irrespective of whether the response is triggered by ethylene (ET), low light or heat (Figure 3.1). Under our conditions, ET is involved in low light-induced hyponastic growth, as revealed by the compromised response of the ein2 mutant (Figure 3.2). However, the ein2 mutants is not as stringently affected as the tga1 tga4 mutant suggesting that other signals than ET require TGA1 and TGA4 to elicit the response. This is supported by the finding that heat-induced hyponastic growth, which is even inhibited by ET, is also diminished in the tga1 tga4 mutant (Figure 3.1). Thus, TGA1 and TGA4 seem to be essential components of hyponastic growth that operate at a potential point of convergence of various signaling cascades.

At least three different ways on the principal function of TGA1 and TGA4 in the 
regulation of hyponastic growth can be envisioned. First, TGA1 and TGA4 might be unregulated amplifiers of the response. For instance, they might be expressed only at the abaxial side, where they would assist to promote induced cell expansion which would explain the asymmetry of the response.

Second, TGA1 and TGA4 might be unregulated amplifiers in terms of eliciting the hyponastic growth as outlined above, but might additionally serve as points of integration of negative signals. Such a role is postulated for TGA2/5/6 in activation of ET-mediated defense responses (Zander et al., 2014). Here, ET-mediated stabilization of ETHYLENE INSENSITIVE 3 (EIN3) is the ET-controlled process, whereas TGA2/5/6 amplify the activating effect of EIN3 to drive expression of the master regulator of the response, ORA59. The positive contribution of TGA2/5/6 on the activity of the ORA59 promoter is counteracted by SA, possibly through ROXY19 and other redundant ROXYs. We found that the negative effect of SA on hyponastic growth is mediated by TGA2/5/6 and NPR1 (Figure 3.5). Consistent with the notion that ROXY19 interferes with the activity of TGA2/5/6, petioles of SA-treated 35S:ROXY19 plants can grow upwards under low light conditions (Figure 3.9C). This observation does not exclude that TGA1 and TGA4 are also involved in this response. However, our complementation lines which express TGA1(C260N/C266S) indicate that the redox-active cysteines are not important for the hypothetical contribution of TGA1 in mediating the inhibitory effect of SA (Figure 3.4B).

Third, TGA1 and TGA4 may be regulated at the protein level by a mechanism that is common to the diverse signaling pathways that induce hyponastic growth (Figure 4.1). We identified ROXY8, ROXY9 and ROXY20 as potential negative regulators of TGA1 and TGA4 activity as revealed by the observation that plants ectopically expressing these proteins are compromised in hyponastic growth (Figure 3.9). Moreover, microarray analyses pointed at a common set of genes that is differentially regulated in tga1 tga4 and 35S:HA-ROXY9 plants as compared to wild-type indicating that ROXY9 and TGA1 /4 regulate the same process (Figure 3.13). Especially the expression pattern of ROXY9 was consistent with the postulated negative role: expression was reduced upon transfer to low light potentially leading to the release 
of TGA1/4 activity so that hyponastic growth is promoted (Figure 3.6B; Figure 3.8). Moreover, ROXY9 was hyper-induced after re-transfer to control light which would lead to the repression of the activity of TGA1/4 allowing reversal of the leaf angle to control conditions (Figure 3.6B; Figure 3.8). However, the roxy9 mutant was indistinguishable from wild-type plants suggesting that other ROXYs might act in a redundant manner (Figure 3.12). Expression of the potentially redundant ROXY8 was hyper-induced by re-transfer to control light, and ROXY2O expression was reduced by low light (Figure 3.8). Expression of all three ROXYs depends on TGA1 and TGA4 which suggests an autoregulatory feed-back loop. A similar loop has been observed before for ROXY19, which represses the activity of TGA2, TGA5 and TGA6 at its own promoter (Ndamukong et al., 2007; Huang et al., 2016). Collectively, these data suggest that environmental cues regulating the activity of TGA1/4-inhibiting ROXYs are molecular components that regulate hyponastic growth in response to a variety of stimuli.
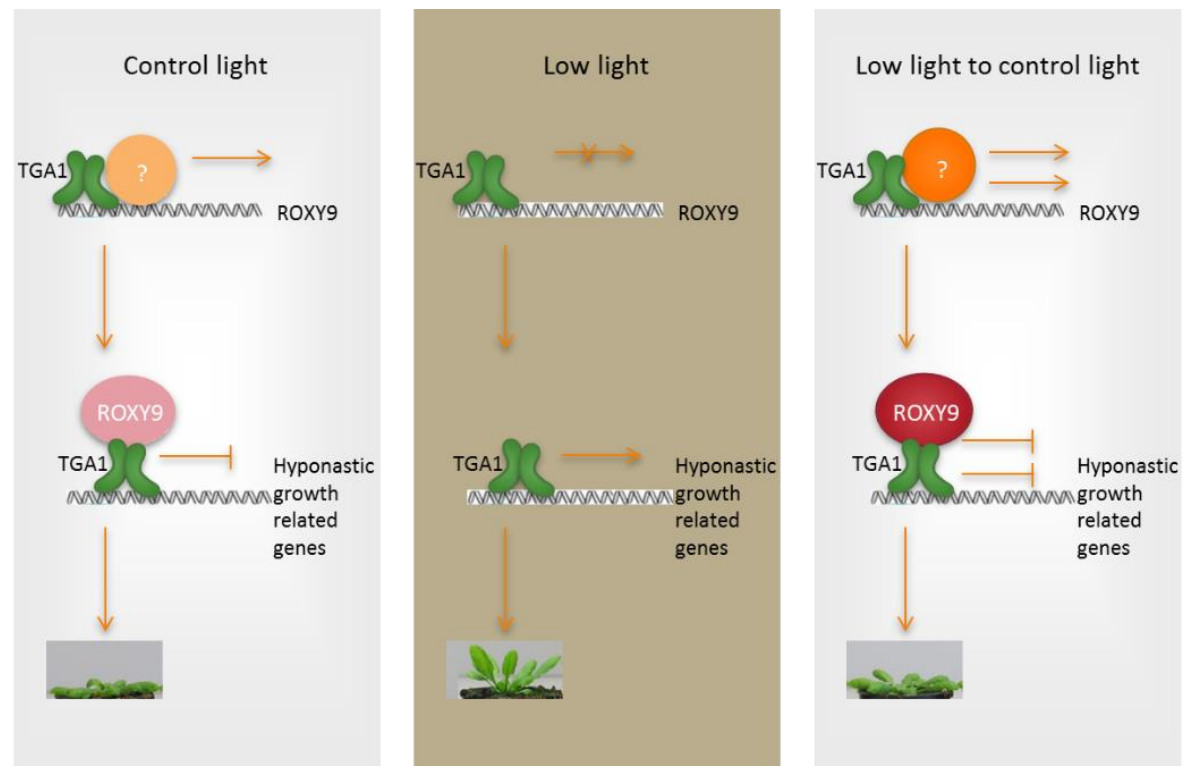

Figure 4.1 Proposed working model.

(A) Under control condition, basal levels of ROXY9 expression are controlled by TGA1/4 and yet unknown transcription factors that can respond to light conditions. ROXY9 interacts with TGA1/4 to reduce the expression of leaf movement-related genes to inhibit hyponastic growth. (B) In response to low light, the expression of ROXY9 is reduced allowing TGA1/4 to stimulate genes involved in cell elongation at the abaxial side of the petiole. (C) When plants are transferred to control light condition after low light pretreatment, ROXY9 expression is strongly re-induced, enabling ROXY9 proteins to accumulate and to repress gene expression by interacting with TGA1/4. 


\subsection{The CC-motif is important for the repressive activity of ROXY9}

Repressive effects of ROXYs on the activity of TGA factors have been described before. Genetic analysis has shown that ROXY1 represses the activity of TGA factor PAN to regulate the initiation of floral primordia (Li et al., 2009). Likewise, ROXY19 represses TGA2/5/6-regulated target promoters (Ndamukong et al., 2007). ROXY1 and ROXY19 contain a C-terminal ALWL motif, which serves to recruit the transcriptional co-repressor TOPLESS to TGA2/5/6-regulated promoters (Uhrig et al., 2017). The ALWL motif is present in 16 of the 21 ROXYs, but not in ROXYs 6, 7, 8, 9 and 21. Interestingly, ROXY19 complements the roxy1 mutant, but does not repress the hyponastic growth (Li et al., 2009). ROXY9 does not complement the roxy1 mutant (Li et al., 2009) and does not repress TGA2/5/6-regulated ORA59 (Zander et al., 2012; Zander et al., 2014). Therefore, the repressive mechanisms of ROXY19 and ROXY9 are most likely different.

The importance of the CCMC motif for ROXY function has been addressed before. As inferred from studies from canonical GRXs, the active site either contributes to oxidoreductase activity or to the binding of [Fe-S] clusters (Fernandes and Holmgren et al., 2004; Bandyopadhyay et al., 2008; Couturier et al., 2011). In vitro studies of a poplar CC-type GRX7.2 have revealed poor oxidoreductase activities on artificial substrates and the potential to bind [Fe-S] clusters (Couturier et al., 2010). In vivo studies with ROXY1 have led to conflicting data sets. When expressed under the CaMV 355 promoter, a mutated ROXY1 encoding a SCMC motif did not complement the roxy1 phenotype (Xing et al., 2005). In contrast, when expressed under the endogenous ROXY1 promoter, the protein was functional. Even mutating the active site into SSMS did not abolish its function (Ziemann et al., 2010; PhD thesis under the supervision of Sabine Zachgo). Plants ectopically expressing ROXY19(CPYC), in which the CCMC motif had been exchanged against the CPYC motif found in class I GRXs, showed the same phenotype as the 35S:ROXY19 control plants (Huang et al., 2016). In contrast, a ROXY19(SSMS) was not functional. This indicates that either 
oxidoreductase or [Fe-S] cluster binding might be important for ROXY19 function, but the relevance of the second cysteine has remained obscure. In this study, the cysteine residues of the CCLC motif of ROXY9 were individually changed into serines. If the first cysteine was mutated, the protein lost its repressive activity (Figure 3.11). In canonical GRXs, the first cysteine of the $\mathrm{CxxC} / \mathrm{S}$ active site is important for the nucleophilic attack of an oxidized sulfur of a (glutathionylated) target protein (Fernandes and Holmgren, 2004). Up to now, it is not known whether ROXY9 has oxidoreductase activity. Moreover, it cannot be excluded, that TGA1 and TGA4 are redox-modulated by ROXY9 at C172 or C287. Interestingly, the second cysteine was also important for function (Figure 3.11). Given that the CC motif in the active site is so conserved, the elucidation of the molecular mechanism of ROXY9 function is extremely important.

\subsection{Low light-induced expression of genes potentially involved in} hyponastic growth are less expressed in tga1 tga4 and 35S:HA-ROXY9 plants

Hyponastic growth is explained by differential expansion rates of cells at the abaxial side of the petiole. Since application of the auxin transport inhibitor TIBA did not strongly interfere with low light-induced hyponastic growth within the first six hours, it has remained unclear what growth-regulating factors create the asymmetry when the response is initiated (Millenaar et al., 2009). Our microarray analysis of RNA of petioles harvested at six after transfer to low light conditions revealed an enrichment of auxin-regulated genes in the cluster of genes that are up-regulated by low light in wild-type but not in the tga1 tga4 and 35S:ROXY19 mutant plants (cluster 5, Figure 3.14). Since primary auxin-responsive genes were up-regulated (e.g. IAA2, IAA3, IAA7, IAA19, IAA29; 3 SAUR-like auxin-responsive protein family proteins) and since only two of these contain a TGACGT motif in the -1000 upstream region, it is unlikely that these genes are direct target genes of TGA1 and TGA4. Thus, TGA1 and TGA4 may be involved in earlier processes leading to increased auxin signaling. This 
TGA1/TGA4-dependent process could be at any step starting from the perception of the environmental signal to the perception of the auxin in the relevant cells. Alternatively, TGA1/TGA4 might be involved in the differential sensitivity of the adaxial side and the abaxial side to the petiole for environmental cues. Therefore, the cellular expression pattern of TGA1 and TGA4 within the leaf has to be investigated. Furthermore, genes involved in cell wall loosening (e.g. XYLOGLYGAN:XYLOGLUCOSY TRANSFERASE 33, XYLOGLUCAN ENDOTRANSGLUCOSYLASE/HYDROLYSES 8 and 15, EXPANSINS 8 and 11) were enriched in cluster 5 (Figure 3.15). It might well be that these genes are induced by auxin. Upon reversal to control light conditions, expression of at least a selected number of these genes is reduced again (Figure 3.16B). These genes are not induced in the adaxial side upon reversal of hyponastic growth and other genes that are expressed on the upper side have to be activated to allow re-orientation of the petioles.

As stated above, we do not have a clue, which of the genes that are essential for hyponastic growth are directly regulated by TGA1 and TGA4. Motif mapper analysis indicated that TGACGT motifs are enriched in the promoters of genes that are higher expressed in tga1 tga4 and 35S:HA-ROXY9 plants (Table 3.1). This finding points at a potential negative effect of TGA1 and TGA4 on genes that are involved in repressing hyponastic growth. However, the high expression of the positive regulator of hyponastic growth, SHYG, in tga1 tga4 and 35S:ROXY19 plants is counterintuitive (Figure 3.21A). Since waterlooging-induced hyponastic growth was not reproduced in our lab, we could not test the response of the tga1 tga4 mutant under these conditions.

Conspicuously, ten ROXY genes are constitutively up-regulated in the tga1 tga4 mutant and 35S:ROXY19 plants. This effect is further enhanced by low light and exceeds by far the levels found in wild-type plants (Figure 3.7; Figure 3.20). Up to now, it cannot be excluded that the unusually high expression of these proteins in tga1 tga4 and 35S:HA-ROXY9 plants influences yet unknown processes that lead to the inhibition of the hyponastic response. 


\section{Conclusion}

Although we do not yet know the direct target genes of TGA1 and TGA4, the phenotype of the tga1 tga4 mutant indicates that they are required for hyponastic growth. Moreover, we identified TGA1-interacting ROXY9 as a potential inhibitor of TGA1 and TGA4 activity. Based on the expression pattern of ROXY9 and the potentially redundant ROXYS ROXY8 and ROXY20, the corresponding promoters could be targets of the various environmental signals that initiate and terminate hyponastic growth. 


\section{Summary}

In the rosette plant Arabidopsis thaliana, different environmental cues trigger upward (hyponastic) leaf movement which is evolutionary beneficial when it comes to avoid shading by neighboring plants. Hyponasty results from longitudinal cell expansion at the lower side of the leaf petiole. Here, we report that clade I TGA transcription factors TGA1 and TGA4 are required for hyponastic growth irrespective of whether it is induced by low light intensities, ethylene or heat. Expression of genes encoding cell wall-loosening or auxin-induced proteins was diminished in petioles of the tga1 tga4 double mutant subjected to low light for six hours. Cysteines C260 and C266 of TGA1, which have been reported to be redox-modulated by the defense hormone salicylic acid (SA) in vivo, do not play a role for the function of TGA1 in hyponastic growth. Likewise, they are not important for the inhibition of hyponastic growth by SA. We identified several TGA1/4-interacting glutaredoxins (ROXY8, ROXY9, ROXY20) as potential negative regulators of TGA1/4 activity. Ectopic expression of ROXY8 and ROXY9 led to plants that show the same hyponasty-deficient phenotype as the tga1 tga4 mutant. Expression of ROXY9 was particularly high when hyponastic plants were transferred back to control light conditions. We therefore favour the hypothesis that the above mentioned ROXYs interfere with TGA1/4 activity in order to mediate the downward orientation of hyponastic leaves after transfer to control conditions. The repressive activity of ROXY9 depends on the integrity of the active site motif CCLC, which might be involved in oxidoreductase activity, binding of iron sulfur complexes or other yet unknown functions. 


\section{References}

Alonso, J.M., Hirayama, T., Roman, G., Nourizadeh, S., and Ecker, J.R. (1999). EIN2, a bifunctional transducer of ethylene and stress responses in Arabidopsis. Science 284: $2148-2152$.

Ballaré, C.L. (2009). Illuminated behaviour: phytochrome as a key regulator of light foraging and plant anti-herbivore defence. Plant Cell Environ. 32: 713-725.

Bandyopadhyay, S., Gama, F., Molina-Navarro, M.M., Gualberto, J.M., Claxton, R., Naik, S.G., Huynh, B.H., Herrero, E., Jacquot, J.P., Johnson, M.K., and Rouhier, N. (2008). Chloroplast monothiol glutaredoxins as scaffold proteins for the assembly and delivery of [2Fe-2S] clusters. EMBO J. 27: 1122-1133.

Benschop, J.J., Millenaar, F.F., Smeets, M.E., Zanten, M. van, Voesenek, L.A.C.J., and Peeters, A.J.M. (2007). Abscisic acid antagonizes ethylene-induced hyponastic growth in Arabidopsis. Plant Physiol. 143: 1013-1023.

Berendzen, K.W., Weiste, C., Wanke, D., Kilian, J., Harter, K., and Dröge-Laser, W. (2012). Bioinformatic cis-element analyses performed in Arabidopsis and rice disclose bZIP- and MYB-related binding sites as potential AuxRE-coupling elements in auxin-mediated transcription. BMC Plant Biol. 12: 125.

Cao, H., Glazebrook, J., Clarke, J.D., Volko, S., and Dong, X. (1997). The Arabidopsis NPR1 gene that controls systemic acquired resistance encodes a novel protein containing ankyrin repeats. Cell 88: 57-63.

Catalá, C., Rose, J.K.C., and Bennett, A.B. (2000). Auxin-regulated genes encoding cell wall-modifying proteins are expressed during early tomato fruit growth. Plant Physiol. 122: 527-534.

Couturier, J. et al. (2011). Arabidopsis chloroplastic glutaredoxin C5 as a model to explore molecular determinants for iron-sulfur cluster binding into glutaredoxins. J. 
Biol. Chem. 286: 27515-27527.

Couturier, J., Didierjean, C., Jacquot, J.-P., and Rouhier, N. (2010). Engineered mutated glutaredoxins mimicking peculiar plant class III glutaredoxins bind iron-sulfur centers and possess reductase activity. Biochem. Biophys. Res. Commun. 403: 435-441.

Cox, M.C.H., Benschop, J.J., Vreeburg, R.A.M., Wagemaker, C.A.M., Moritz, T., Peeters, A.J.M., and Voesenek, L.A.C.J. (2004). The roles of ethylene, auxin, abscisic acid, and gibberellin in the hyponastic growth of submerged Rumex palustris petioles. Plant Physiol. 136: 2948-2960.

Cox, M.C.H., Millenaar, F.F., van Berkel, Y.E.M. de J., Peeters, A.J.M., and Voesenek, L.A.C.J. (2003). Plant movement. submergence-induced petiole elongation in Rumex palustris depends on hyponastic growth. Plant Physiol. 132: 282-291.

Després, C., Chubak, C., Rochon, A., Clark, R., Bethune, T., Desveaux, D., and Fobert, P.R. (2003). The Arabidopsis NPR1 disease resistance protein is a novel cofactor that confers redox regulation of dna binding activity to the basic domain/leucine zipper transcription factor TGA1. Plant Cell 15: 2181-2191.

Ecker, J.R. (1995). The ethylene signal transduction pathway in plants. Science 268: 667-675.

Fernandes, A.P. and Holmgren, A. (2004). Glutaredoxins: glutathione-dependent redox enzymes with functions far beyond a simple thioredoxin backup system. Antioxid. Redox Signal. 6: 63-74.

Fode, B., Siemsen, T., Thurow, C., Weigel, R., and Gatz, C. (2008). The Arabidopsis GRAS protein SCL14 interacts with class II TGA Transcription factors and is essential for the activation of stress-inducible promoters. Plant Cell 20: 3122-3135.

Franklin, K.A. (2008). Shade avoidance. New Phytol. 179: 930-944. 
Friedman, H., Vos, J.W., Hepler, P.K., Meir, S., Halevy, A.H., and Philosoph-Hadas, S. (2003). The role of actin filaments in the gravitropic response of snapdragon flowering shoots. Planta 216: 1034-1042.

Friml, J. and Palme, K. (2002). Polar auxin transport--old questions and new concepts? Plant Mol. Biol. 49: 273-284.

Glaser, T., Hedman, B., Hodgson, K.O., and Solomon, E.I. (2000). Ligand K-edge X-ray absorption spectroscopy: A direct probe of ligand-metal covalency. Acc. Chem. Res. 33.

Gutsche, N., Thurow, C., Zachgo, S., and Gatz, C. (2015). Plant-specific CC-type glutaredoxins: functions in developmental processes and stress responses. Biol. Chem. 396: 495-509.

Huang, L.-J., Li, N., Thurow, C., Wirtz, M., Hell, R., and Gatz, C. (2016). Ectopically expressed glutaredoxin ROXY19 negatively regulates the detoxification pathway in Arabidopsis thaliana. BMC Plant Biol. 16: 200.

Jakoby, M., Weisshaar, B., Dröge-Laser, W., Vicente-Carbajosa, J., Tiedemann, J., Kroj, T., Parcy, F., and bZIP Research Group (2002). bZIP transcription factors in Arabidopsis. Trends Plant Sci. 7: 106-111.

Johnson, D.C., Dean, D.R., Smith, A.D., and Johnson, M.K. (2005). Structure, function, and formation of biological iron-sulfur clusters. Annu. Rev. Biochem. 74: $247-281$.

Kaever, A., Landesfeind, M., Feussner, K., Morgenstern, B., Feussner, I., and Meinicke, P. (2014). Meta-analysis of pathway enrichment: combining independent and dependent omics data sets. PloS One 9: e89297.

Kaever, A., Landesfeind, M., Possienke, M., Feussner, K., Feussner, I., and Meinicke, P. (2012). MarVis-Filter: ranking, filtering, adduct and isotope correction of mass 
spectrometry data. J. Biomed. Biotechnol. 2012: 263910.

Kaever, A., Lingner, T., Feussner, K., Göbel, C., Feussner, I., and Meinicke, P. (2009). MarVis: a tool for clustering and visualization of metabolic biomarkers. BMC Bioinformatics 10: 92.

Kang BG (1979). Epinasty. In W Haupt, ME Feinleib, eds, Encyclopedia of plant physiology, New Series, Vol 7, Physiology of movements. Springer-Verlag, Berlin, pp 647-667

Katagiri F, Lam E and Chua NH. (1989). Two tobacco DNA-binding proteins with homology to the nuclear factor CREB. Nature 340: 727-730.

Katagiri, F., Seipel, K., and Chua, N.H. (1992). Identification of a novel dimer stabilization region in a plant bZIP transcription activator. Mol. Cell. Biol. 12: 4809-4816.

Kaufman PB, Wu LL, Brock TG, Kim D. (1995) Hormones and the orientation of growth. In PJ Davies, ed, Plant Hormones. Kluwer Academic, Dordrecht, The Netherlands, pp 547-571.

Kesarwani, M., Yoo, J., and Dong, X. (2007). genetic interactions of TGA transcription factors in the regulation of pathogenesis-related genes and disease resistance in Arabidopsis. Plant Physiol. 144: 336-346.

Keuskamp, D.H., Sasidharan, R., and Pierik, R. (2010). Physiological regulation and functional significance of shade avoidance responses to neighbors. Plant Signal. Behav. 5: 655-662.

Koini, M.A., Alvey, L., Allen, T., Tilley, C.A., Harberd, N.P., Whitelam, G.C., and Franklin, K.A. (2009). High temperature-mediated adaptations in plant architecture require the bHLH transcription factor PIF4. Curr. Biol. CB 19: 408-413. 
Koncz, C. and Schell, J. (1986). The promoter of TL-DNA gene 5 controls the tissue-specific expression of chimaeric genes carried by a novel type of Agrobacterium binary vector. Mol. Gen. Genet. MGG 204: 383-396.

La Camera, S., L'Haridon, F., Astier, J., Zander, M., Abou-Mansour, E., Page, G., Thurow, C., Wendehenne, D., Gatz, C., Métraux, J.-P., and Lamotte, O. (2011). The glutaredoxin ATGRXS13 is required to facilitate Botrytis cinerea infection of Arabidopsis thaliana plants. Plant J. 68: 507-519.

Lai, Z., Schluttenhofer, C.M., Bhide, K., Shreve, J., Thimmapuram, J., Lee, S.Y., Yun, D.-J., and Mengiste, T. (2014). MED18 interaction with distinct transcription factors regulates multiple plant functions. Nat. Commun. 5: 3064.

Lam E, Benfey PN, Gilmartin PM, Fang R and Chua NH. (1989). Site-specific mutations alter in vitro factor binding and change promoter expression pattern in transgenic plants. Proc. Natl. Acad. Sci. 86: 7890-7894.

Lam, E. and Lam, Y.K. (1995). Binding site requirements and differential representation of TGF factors in nuclear ASF-1 activity. Nucleic Acids Res. 23: $3778-3785$.

Lariguet, P., Schepens, I., Hodgson, D., Pedmale, U.V., Trevisan, M., Kami, C., de Carbonnel, M., Alonso, J.M., Ecker, J.R., Liscum, E., and Fankhauser, C. (2006). PHYTOCHROME KINASE SUBSTRATE 1 is a phototropin 1 binding protein required for phototropism. Proc. Natl. Acad. Sci. U. S. A. 103: 10134-10139.

Lee, S.C., Mustroph, A., Sasidharan, R., Vashisht, D., Pedersen, O., Oosumi, T., Voesenek, L.A.C.J., and Bailey-Serres, J. (2011). Molecular characterization of the submergence response of the Arabidopsis thaliana ecotype Columbia. New Phytol. 190: $457-471$.

Lemaire, S.D. (2004). The glutaredoxin family in oxygenic photosynthetic organisms. Photosynth. Res. 79: 305-318. 
Li, S., Lauri, A., Ziemann, M., Busch, A., Bhave, M., and Zachgo, S. (2009). Nuclear activity of ROXY1, a glutaredoxin interacting with TGA factors, is required for petal development in Arabidopsis thaliana. Plant Cell 21: 429-441.

Lillig, C.H., Berndt, C., and Holmgren, A. (2008). Glutaredoxin systems. Biochim. Biophys. Acta 1780: 1304-1317.

Lindermayr, C., Sell, S., Müller, B., Leister, D., and Durner, J. (2010). Redox regulation of the NPR1-TGA1 system of Arabidopsis thaliana by nitric oxide. Plant Cell 22: 2894-2907.

Lohse, M. et al. (2010). Robin: an intuitive wizard application for R-based expression microarray quality assessment and analysis. Plant Physiol. 153: 642-651.

Meinicke, P., Lingner, T., Kaever, A., Feussner, K., Göbel, C., Feussner, I., Karlovsky, P., and Morgenstern, B. (2008). Metabolite-based clustering and visualization of mass spectrometry data using one-dimensional self-organizing maps. Algorithms Mol. Biol. AMB 3: 9.

Millenaar, F.F., Cox, M.C.H., de Jong van Berkel, Y.E.M., Welschen, R.A.M., Pierik, R., Voesenek, L.A.J.C., and Peeters, A.J.M. (2005). Ethylene-induced differential growth of petioles in Arabidopsis. analyzing natural variation, response kinetics, and regulation. Plant Physiol. 137: 998-1008.

Millenaar, F.F., Van Zanten, M., Cox, M.C.H., Pierik, R., Voesenek, L.A.C.J., and Peeters, A.J.M. (2009). Differential petiole growth in Arabidopsis thaliana: photocontrol and hormonal regulation. New Phytol. 184: 141-152.

Mockler, T.C., Guo, H., Yang, H., Duong, H., and Lin, C. (1999). Antagonistic actions of Arabidopsis cryptochromes and phytochrome B in the regulation of floral induction. Dev. Camb. Engl. 126: 2073-2082.

Mueller, S., Hilbert, B., Dueckershoff, K., Roitsch, T., Krischke, M., Mueller, M.J., and 
Berger, S. (2008). General detoxification and stress responses are mediated by oxidized lipids through TGA transcription factors in Arabidopsis. Plant Cell 20: $768-785$.

Murmu, J., Bush, M.J., DeLong, C., Li, S., Xu, M., Khan, M., Malcolmson, C., Fobert, P.R., Zachgo, S., and Hepworth, S.R. (2010). Arabidopsis bZIP transcription factors TGA9 and TGA10 interact with floral glutaredoxins ROXY1 and ROXY2 and are redundantly required for anther development. Plant Physiol.: pp.110.159111.

Muthreich, M. (2014). Characterization of clade I TGA transcription factors in Arabidopsis thaliana with respect to biotic stress. PhD thesis.

(https://ediss.uni-goettingen.de/bitstream/handle/11858/00-1735-0000-0022-5FB1-8/Thesi s_MM_corrected_publish.pdf?sequence=1)

Ndamukong, I., Abdallat, A.A., Thurow, C., Fode, B., Zander, M., Weigel, R., and Gatz, C. (2007). SA-inducible Arabidopsis glutaredoxin interacts with TGA factors and suppresses JA-responsive PDF1.2 transcription. Plant J. Cell Mol. Biol. 50: 128-139.

Ordin, L., Applewhite, T.H., and Bonner, J. (1956). Auxin-induced water uptake by avena coleoptile sections. Plant Physiol. 31: 44-53.

Pierik, R., Millenaar, F.F., Peeters, A.J.M., and Voesenek, L. a. C.J. (2005). New perspectives in flooding research: the use of shade avoidance and Arabidopsis thaliana. Ann. Bot. 96: 533-540.

Polko, J.K. et al. (2015). Ethylene-mediated regulation of A2-type CYCLINs modulates hyponastic growth in Arabidopsis. Plant Physiol. 169: 194-208.

Polko, J.K., van Zanten, M., van Rooij, J.A., Marée, A.F.M., Voesenek, L.A.C.J., Peeters, A.J.M., and Pierik, R. (2012). Ethylene-induced differential petiole growth in Arabidopsis thaliana involves local microtubule reorientation and cell expansion. New Phytol. 193: 339-348. 
Poor, C.B., Wegner, S.V., Li, H., Dlouhy, A.C., Schuermann, J.P., Sanishvili, R., Hinshaw, J.R., Riggs-Gelasco, P.J., Outten, C.E., and He, C. (2014). Molecular mechanism and structure of the Saccharomyces cerevisiae iron regulator Aft2. Proc. Natl. Acad. Sci. U. S. A. 111: 4043-4048.

Rauf, M., Arif, M., Fisahn, J., Xue, G.-P., Balazadeh, S., and Mueller-Roeber, B. (2013). NAC transcription factor SPEEDY HYPONASTIC GROWTH regulates flooding-induced leaf movement in Arabidopsis. Plant Cell 25: 4941-4955.

Reed, J.W., Nagpal, P., Poole, D.S., Furuya, M., and Chory, J. (1993). Mutations in the gene for the red/far-red light receptor phytochrome B alter cell elongation and physiological responses throughout Arabidopsis development. Plant Cell 5: 147-157.

Ritsema, T., van Zanten, M., Leon-Reyes, A., Voesenek, L.A.C.J., Millenaar, F.F., Pieterse, C.M.J., and Peeters, A.J.M. (2010). Kinome profiling reveals an interaction between jasmonate, salicylate and light control of hyponastic petiole growth in Arabidopsis thaliana. PLoS ONE 5.

Robson, P., Whitelam, G.C., and Smith, H. (1993). Selected components of the shade-avoidance syndrome are displayed in a normal manner in mutants of Arabidopsis thaliana and Brassica rapa deficient in Phytochrome B. Plant Physiol. 102: $1179-1184$.

Roman, G., Lubarsky, B., Kieber, J.J., Rothenberg, M., and Ecker, J.R. (1995). Genetic analysis of ethylene signal transduction in Arabidopsis thaliana: five novel mutant loci integrated into a stress response pathway. Genetics 139: 1393-1409.

Running, M.P. and Meyerowitz, E.M. (1996). Mutations in the PERIANTHIA gene of Arabidopsis specifically alter floral organ number and initiation pattern. Dev. Camb. Engl. 122: 1261-1269.

Shearer, H.L., Cheng, Y.T., Wang, L., Liu, J., Boyle, P., Després, C., Zhang, Y., Li, X., and Fobert, P.R. (2012). Arabidopsis clade I TGA transcription factors regulate plant 
defenses in an NPR1-independent fashion. Mol. Plant-Microbe Interact. MPMI 25: 1459-1468.

Spoel, S.H. et al. (2003). NPR1 modulates cross-talk between salicylate- and jasmonate-dependent defense pathways through a novel function in the cytosol. Plant Cell 15: 760-770.

Taiz L. (1984). Plant cell expansion: regulation of cell wall mechanical properties. Annu Rev Plant Physiol. 35:585-657.

Uhrig, J.F., Huang, L.-J., Barghahn, S., Willmer, M., Thurow, C., and Gatz, C. (2017). CC-type glutaredoxins recruit the transcriptional co-repressor TOPLESS to TGA-dependent target promoters in Arabidopsis thaliana. Biochim. Biophys. Acta 1860: 218-226.

Vandenbussche, F., Vriezen, W.H., Smalle, J., Laarhoven, L.J.J., Harren, F.J.M., and Van Der Straeten, D. (2003). Ethylene and auxin control the arabidopsis response to decreased light intensity. Plant Physiol. 133: 517-527.

Vreeburg, R.A.M., Benschop, J.J., Peeters, A.J.M., Colmer, T.D., Ammerlaan, A.H.M., Staal, M., Elzenga, T.M., Staals, R.H.J., Darley, C.P., McQueen-Mason, S.J., and Voesenek, L.A.C.J. (2005). Ethylene regulates fast apoplastic acidification and expansin A transcription during submergence-induced petiole elongation in Rumex palustris. Plant J. Cell Mol. Biol. 43: 597-610.

Wang, L. and Fobert, P.R. (2013). Arabidopsis clade I TGA factors regulate apoplastic defences against the bacterial pathogen Pseudomonas syringae through endoplasmic reticulum-based processes. PloS One 8: e77378.

Weiste, C., Iven, T., Fischer, U., Oñate-Sánchez, L., and Dröge-Laser, W. (2007). In planta ORFeome analysis by large-scale over-expression of GATEWAY-compatible cDNA clones: screening of ERF transcription factors involved in abiotic stress defense. Plant J. Cell Mol. Biol. 52: 382-390. 
Went, F.W., and Thimann, K.V. (1937). Phytohormones. (New York MacMillan).

Whitelam, G.C. and Johnson, C.B. (1982). Photomorphogenesis in impatiens parviflora and other plant species under simulated natural canopy radiations. New Phytol. 90: 611-618.

Xing, S., Rosso, M.G., and Zachgo, S. (2005). ROXY1, a member of the plant glutaredoxin family, is required for petal development in Arabidopsis thaliana. Development 132: 1555-1565.

Xing, S. and Zachgo, S. (2008). ROXY1 and ROXY2, two Arabidopsis glutaredoxin genes, are required for anther development. Plant J. 53: 790-801.

Zander, M., La Camera, S., Lamotte, O., Métraux, J.-P., and Gatz, C. (2010). Arabidopsis thaliana class-II TGA transcription factors are essential activators of jasmonic acid/ethylene-induced defense responses. Plant J. 61: 200-210.

Zander, M., Chen, S., Imkampe, J., Thurow, C., and Gatz, C. (2012). Repression of the Arabidopsis thaliana jasmonic acid/ethylene-induced defense pathway by tga-interacting glutaredoxins depends on their C-terminal ALWL motif. Mol. Plant 5: 831-840.

Zander, M., Thurow, C., and Gatz, C. (2014). TGA transcription factors activate the salicylic acid-suppressible branch of the ethylene-induced defense program by regulating ORA59 expression. Plant Physiol. 165: 1671-1683.

van Zanten, M., Millenaar, F.F., Cox, M.C., Pierik, R., Voesenek, L.A., and Peeters, A.J. (2009). Auxin perception and polar auxin transport are not always a prerequisite for differential growth. Plant Signal. Behav. 4: 899-901.

van Zanten, M., Ritsema, T., Polko, J.K., Leon-Reyes, A., Voesenek, L.A.C.J., Millenaar, F.F., Pieterse, C.M.J., and Peeters, A.J.M. (2012). Modulation of ethylene- 
and heat-controlled hyponastic leaf movement in Arabidopsis thaliana by the plant defence hormones jasmonate and salicylate. Planta 235: 677-685.

Zhang, Y., Fan, W., Kinkema, M., Li, X., and Dong, X. (1999). Interaction of NPR1 with basic leucine zipper protein transcription factors that bind sequences required for salicylic acid induction of the PR-1 gene. Proc. Natl. Acad. Sci. U. S. A. 96: 6523-6528.

Zhang, Y., Tessaro, M.J., Lassner, M., and Li, X. (2003). Knockout analysis of arabidopsis transcription factors TGA2, TGA5, and TGA6 reveals their redundant and essential roles in systemic acquired resistance. Plant Cell 15: 2647-2653.

Ziemann, M. (2014). Glutaredoxin family genes in plant development. PhD thesis. (https://researchbank.swinburne.edu.au/file/a43ce9b6-69a0-4011-b81b-9f129dbc4ae3/1/Mark\%20Ziem ann\%20Thesis.pdf)

Ziemann, M., Bhave, M., and Zachgo, S. (2009). Origin and diversification of land plant CC-type glutaredoxins. Genome Biol. Evol. 1: 265-277. 


\section{Abbreviations}

ABA

ACC

A. thaliana

A. tumefaciens

ACC

as-1

bHLH

bZIP

$\mathrm{CL}$

Col-0

CRISPR

EDTA

ET

$\mathrm{EtOH}$

Fe-S

FR

Gent $^{R}$

GO

GR

GRX

GSH

LL

$J A$

NAC

$\mathrm{NADPH}$

$p$

PCA

PCR

QRT-PCR

$R$

Rif $^{R}$

ROXY

SA

SD

SDS

SDS-PAGE

TF

TGA

WT
Abscisic acid

1-aminocyclopropane-1-carboxylic acid

Arabidopsis thaliana

Agrobacterium tumefaciens

1-aminocyclopropane-1-carboxylic acid

activation sequence-1

Basic helix-loop-helix

Basic domain/leucine zipper

Control light

Columbia

Clustered regularly interspaced short palindromic repeats

Ethylene di-amine tetra-acetic acid

Ethylene

Ethanol

Iron-sulfur

Far-red light

Gentamicin

Gene ontology

Glutathione reductase

Glutaredoxin

Glutathione

Low light

Jasmonic acid

NAC (NAM, ATAF1/2, CUC2) transcription factor

Nicotinamide adenine dinucleotide phosphate

$p$-value (probability of obtaining a test statistic assuming that the null hypothesis is true)

Principal components analysis

Polymerase chain reaction

Quantitative real-time PCR

Red light

Rifampicin

CC-type glutaredoxin

Salicylic acid

Short day

Sodium dodecyl sulfate

Sodium dodecyl sulfate-polyacrylamide gel electrophoresis

Transcription factor

TGACG motif binding protein

Wild-type 


\section{Supplementary data}

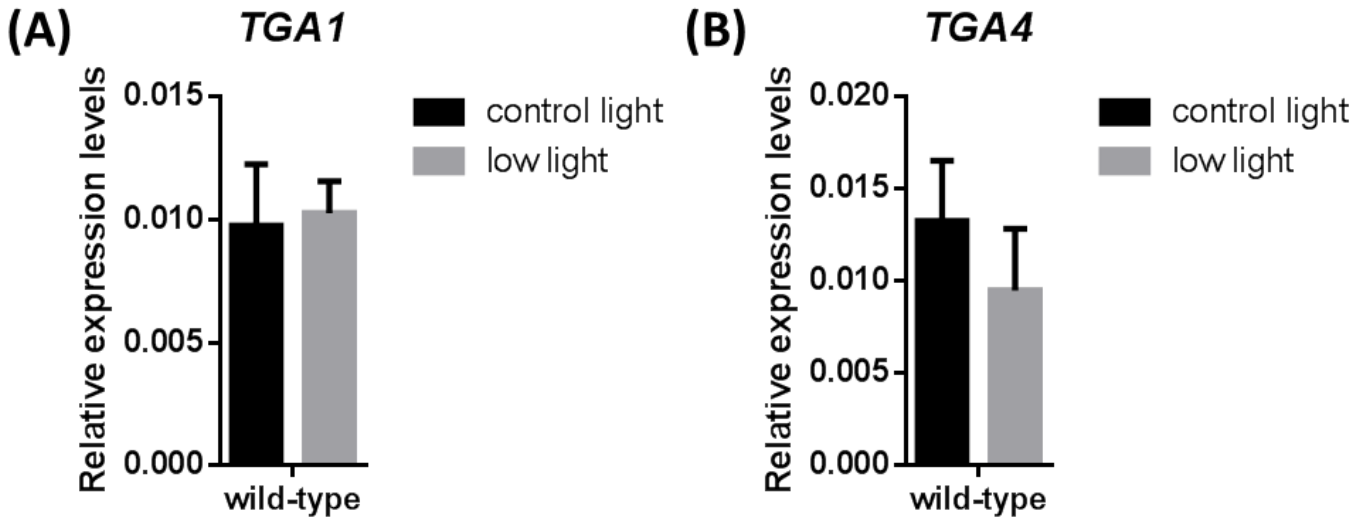

Supplementary Figure S1 Expression profiling of TGA1 and TGA4 in wild-type after low light treatment.

(A) and (B) qRT-PCR analysis of TGA1 and TGA4 expression in wild-type after low light treatment. Four-week-old soil-grown wild-type were treated with low light for 6 hours (reduction in light intensity from $100-120$ to $15-20 \mu \mathrm{mol} \mathrm{m}-2 \mathrm{~s}-1$ ). Transcript levels were normalized to the transcript level of UBQ5. Bars represent the average \pm SEM of four biological replicates, each with dissected petioles from five independent plants. 


\section{ROXY4}

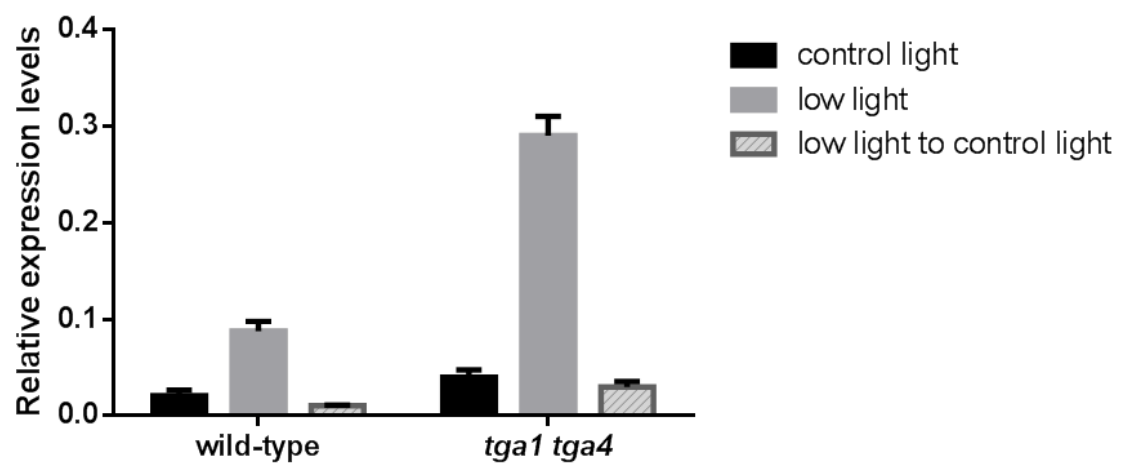

Supplementary Figure S2 Expression profiling of ROXY4 in wild-type and tga1 tga4 in light shifting assay.

qRT-PCR analysis of ROXY4 expression in light shifting assay. Transcript levels were normalized to the transcript level of UBQ5 (ubiquitin 5). Error bars represent the average \pm SEM of five biological replicates, each with dissected petioles from five independent plants. 


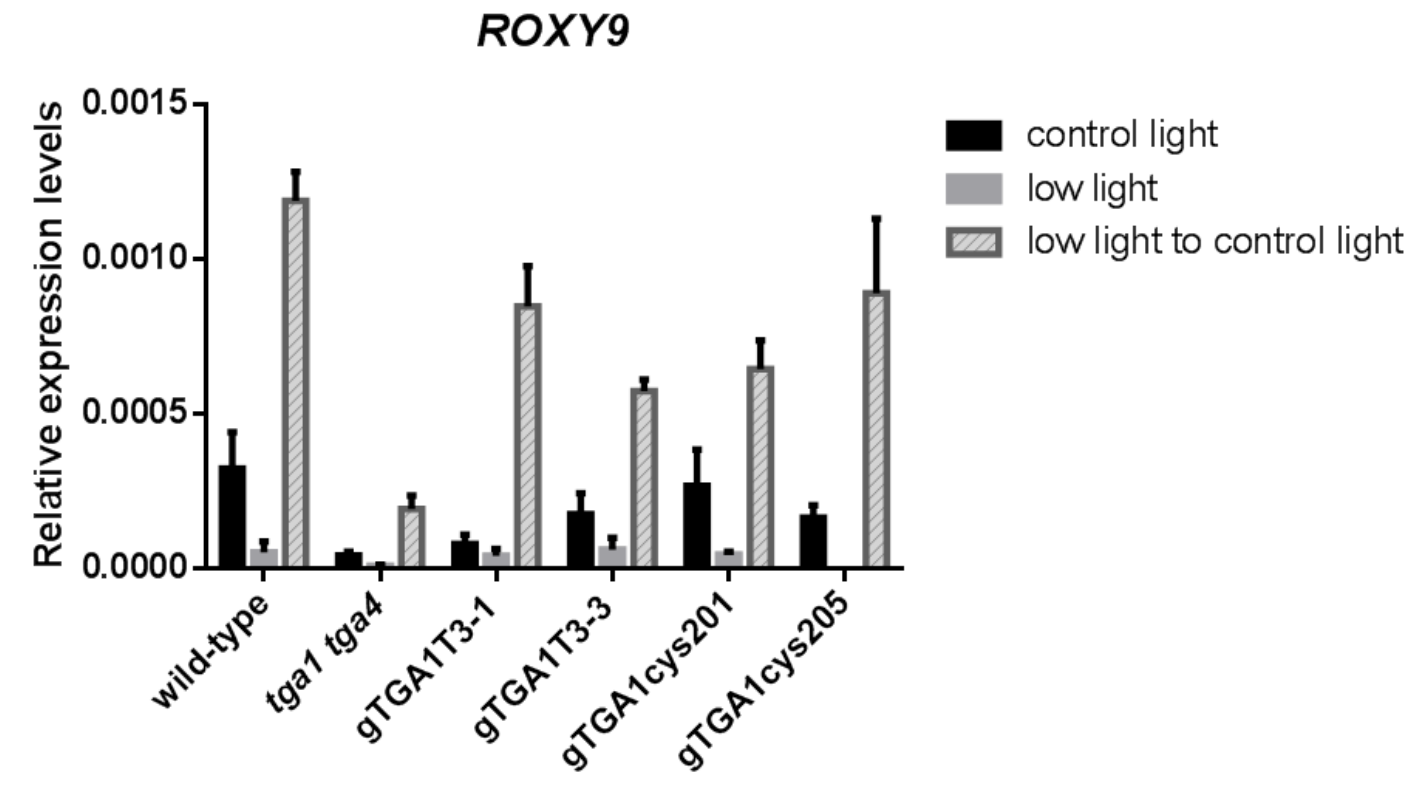

Supplementary Figure S3 Expression profiling of ROXY9 in genomic TGA1 complementation lines.

qRT-PCR analysis of ROXY9 expression in light shifting assay. Plants were subjected to the light regime displayed in Figure 3.6A. Four-week soil-grown wild-type, tga1 tga4, gTGA1(ProTGA1:HA-TGA1 line 1 and line 3), and gTGA1cys(ProTGA1:HA-TGA1 with mutations in the two conserved cysteines, CNLKQSC to NNLKQSS, line 1 and line 5) plants were harvested. Transcript levels were normalized to the transcript level of UBQ5 (ubiquitin 5). Data are mean values of three biological replicates, each with dissected petioles from three independent plants. Error bars=SEM 


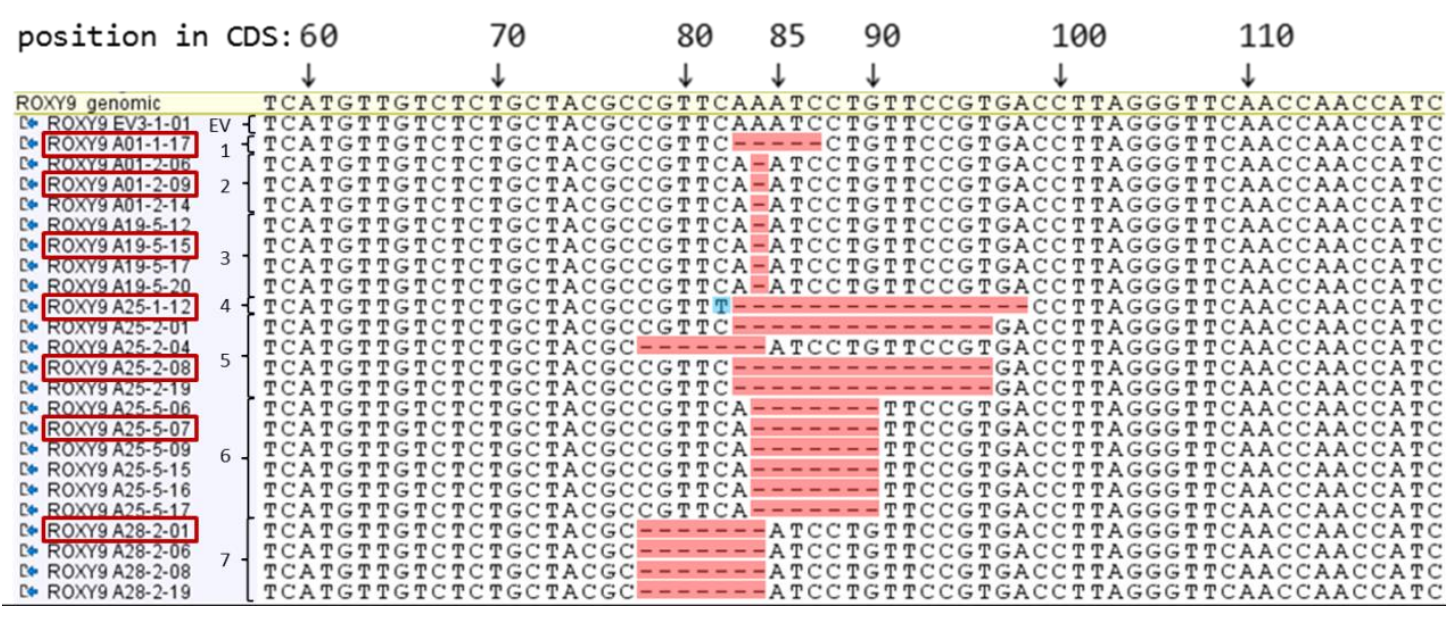

\section{Supplementary Figure S4 ROXY9 CRISPR-Cas9 mutant lines.}

Mutant lines which were selected for light shifting assay were circled with red rectangle. Deleted nucleotides in ROXY9 CRISPR-Cas9 mutants were indicated with short lines in red background. The mutated nucleotide was marked in blue background. DNA sequences aligned by Florian Jung (Master thesis). 


\section{Supplementary Figure S5}

wild-type and tga 1 tga 4 in response to 6 hours high temperature treatment
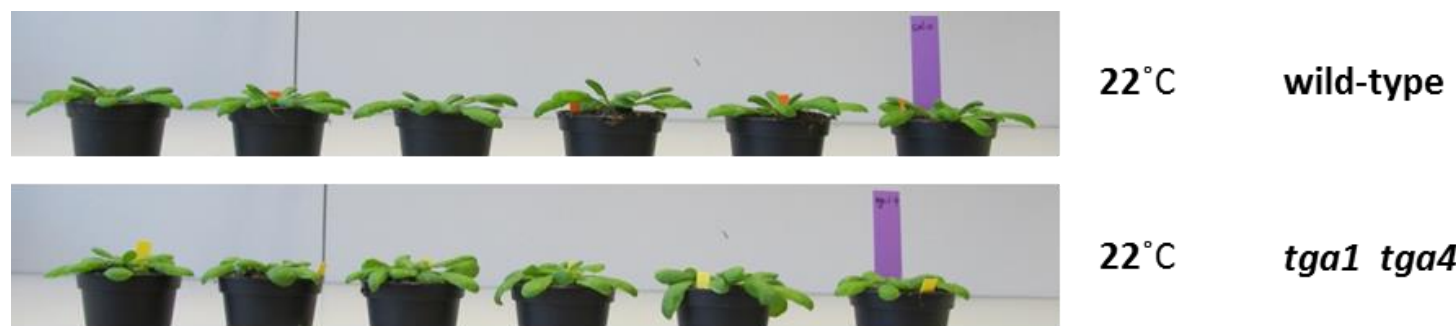

$22^{\circ} \mathrm{C}$

$\operatorname{tga1} \operatorname{tga4}$

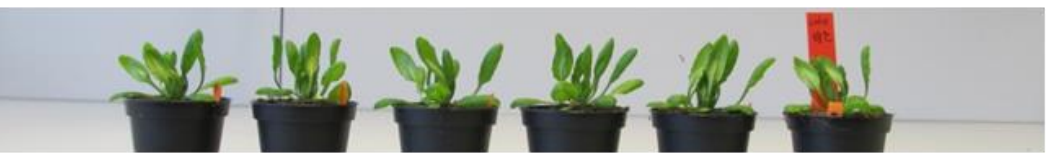

$38^{\circ} \mathrm{C}$

wild-type

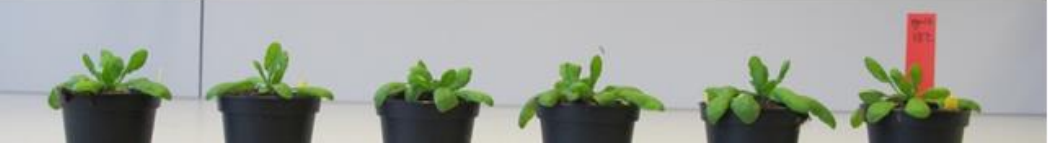




\section{Supplementary Figure S6}

wild-type, ein2, 35S:SHYG, shyg-1 and shyg-2 in response to 6 hours low light treatment. Images were used for petiole angle measurement in Figure 3.2B and Figure 3.21B.

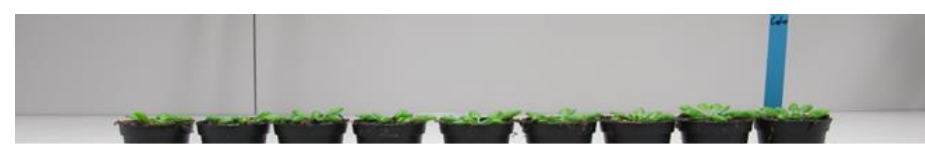

control light

wild-type

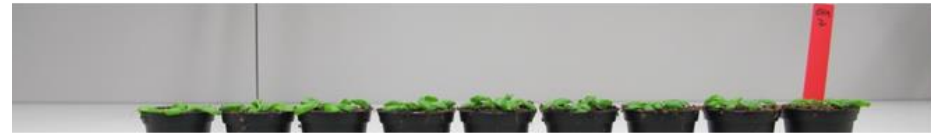

control light

ein2

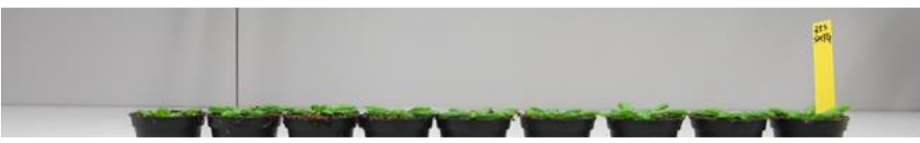

control light

35S:SHYG

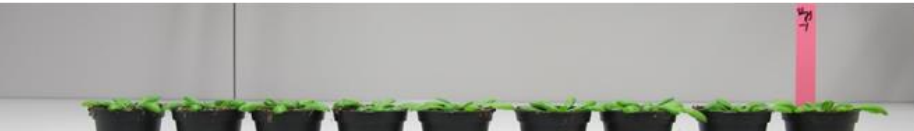

control light

shyg-1

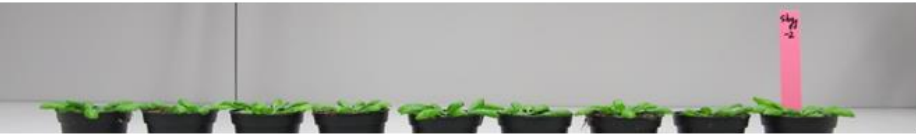

control light

shyg-2

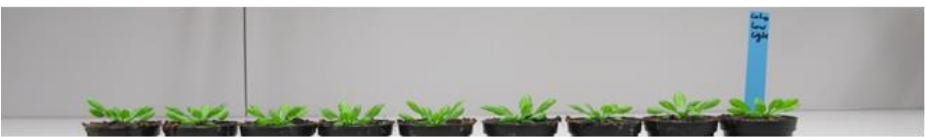

low light

wild-type

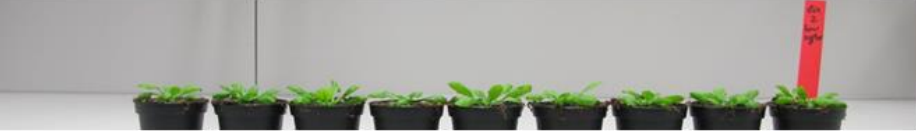

low light

ein2

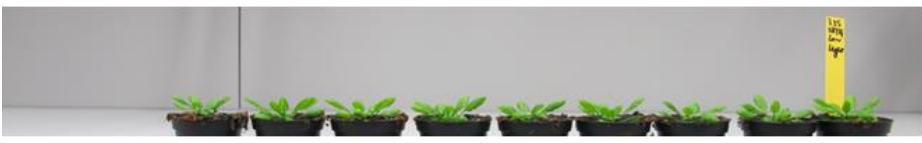

low light

35S:SHYG

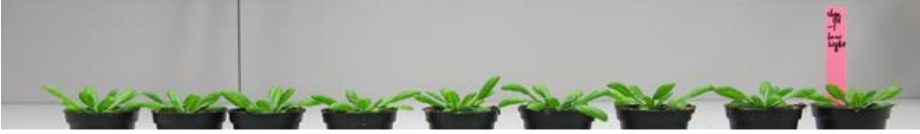

low light

shyg-1

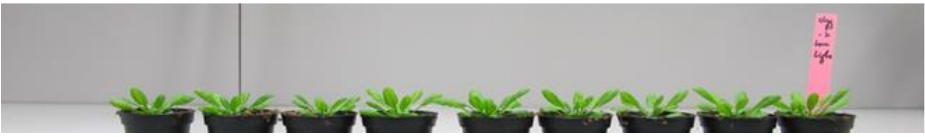

low light

shyg-2 


\section{Supplementary Figure S7}

wild-type, cry1 cry2, and phot1 phot 2 in response to 6 hours low light treatment. Images were used for petiole angle measurement in Figure 3.2C, D.

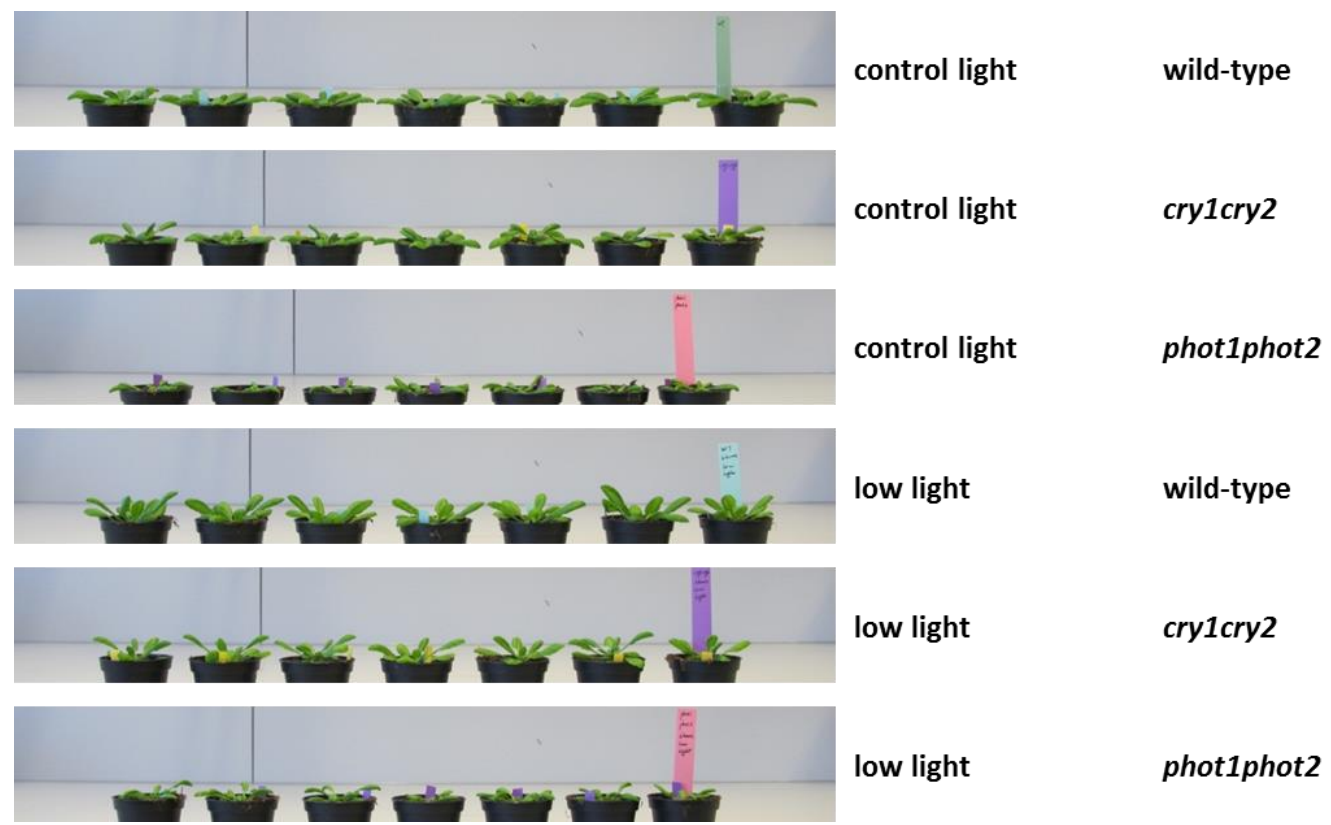

Wild-type, and phyB in response to 6 hours low light treatment
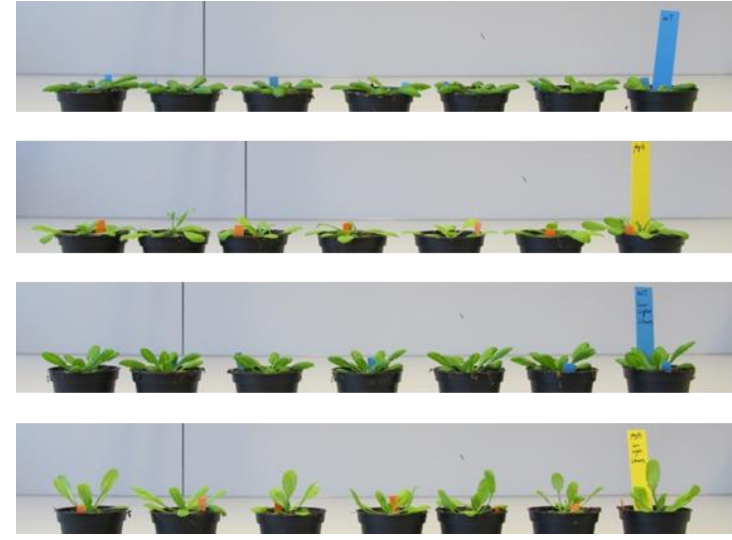

low light wild-type

phyB

wild-type

phyB 


\section{Supplementary Figure $\mathbf{8 8}$}

wild-type, tga1 tga4, gTGA1\#1, gTGA1\#3, gTGA1cys\#1 and gTGA1cys\#3 in response to 6 hours ACC treatment. Images were used for petiole angle measurement in Figure 3.3C.
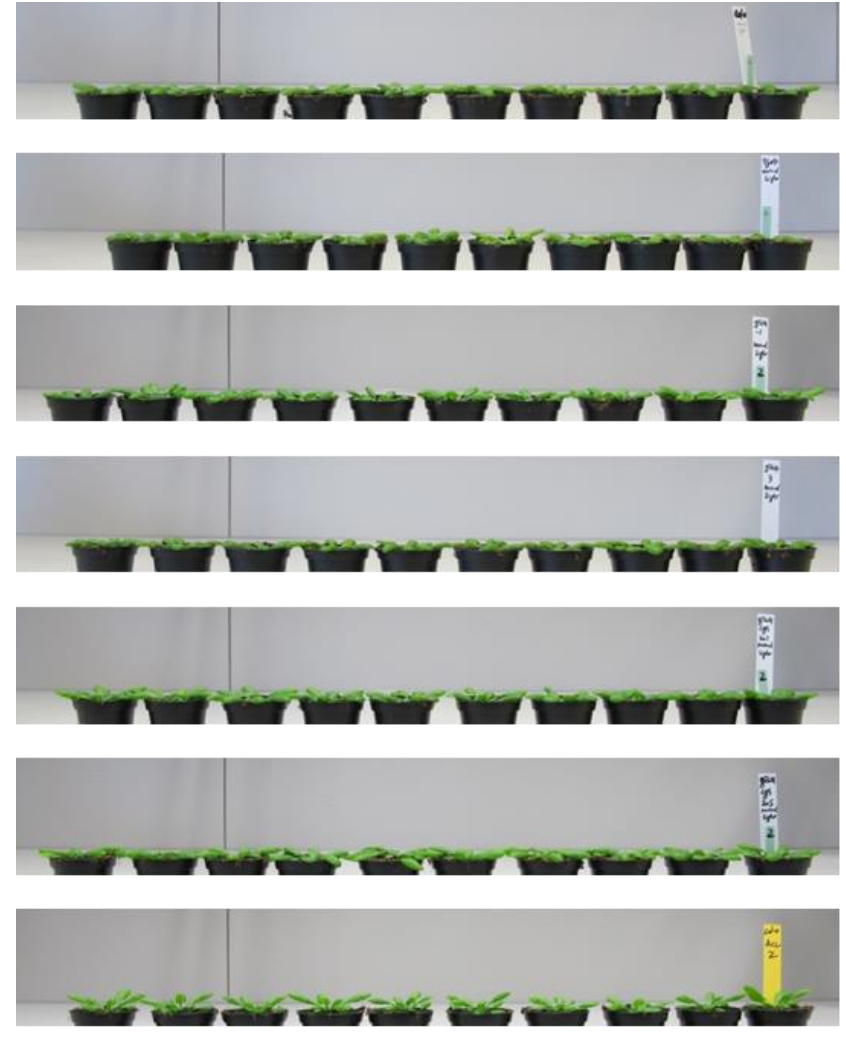

ACC
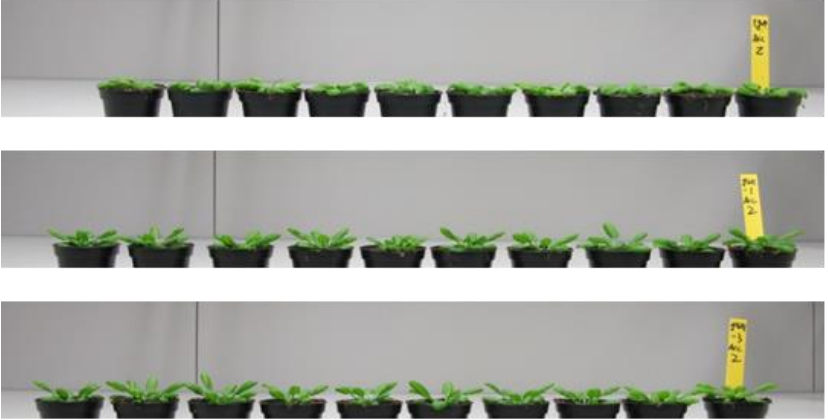

ACC
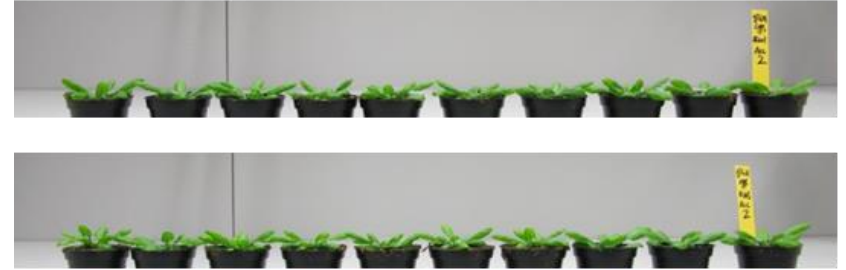

control light

ACC

ACC

ACC

control light

control light

control light

control light

control light

ACC wild-type

$\operatorname{tga1} \operatorname{tga} 4$

gTGA1 \#1

gTGA1 \#3

gTGA1cys \#1

gTGA1cys \#3

wild-type

$\operatorname{tga1} \operatorname{tga} 4$

gTGA1 \#1

gTGA1 \#3

gTGA1cys \#1

gTGA1cys \#3 


\section{Supplementary Figure $\mathbf{S 9}$}

wild-type, tga1 tga4, gTGA1\#1, gTGA1\#3, gTGA1Cys\#1 and gTGA1cys\#3 in response to 6 hours low light treatment. Images were used for petiole angle measurement in Figure 3.3B.

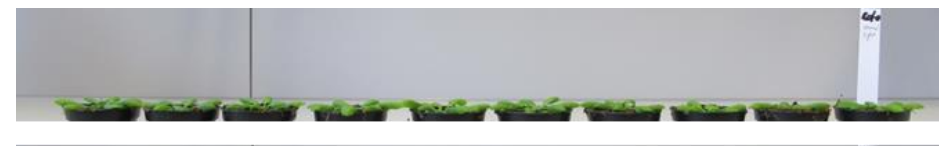

control light

control light
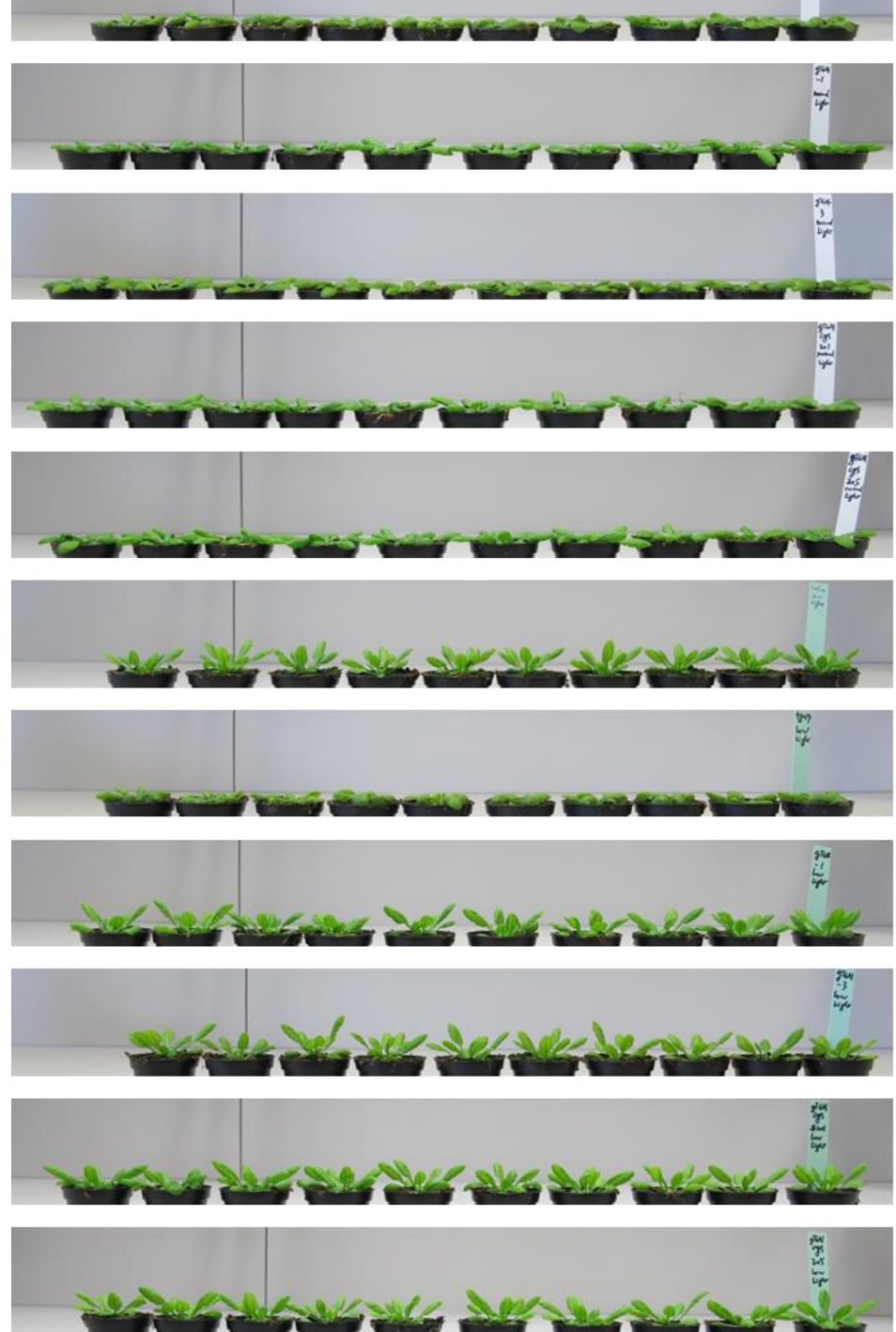

\section{control light}

control light

control light

control light

low light

low light

low light

low light

low light

low light wild-type

tga1 tga 4

gTGA1 \#1

gTGA1 \#3

gTGA1cys \#1

gTGA1cys \#3

wild-type

tga1 tga4

gTGA1 \#1

gTGA1 \#3

gTGA1cys \#1

gTGA1cys \#3 


\section{Supplementary Figure S10}

wild-type, tga1 tga4, gTGA1\#1, gTGA1\#3, gTGA1Cys\#1 and gTGA1cys\#3 in response to 6 hours low light, low light plus SA treatment. Images were used for petiole angle measurement in Figure 3.4B.

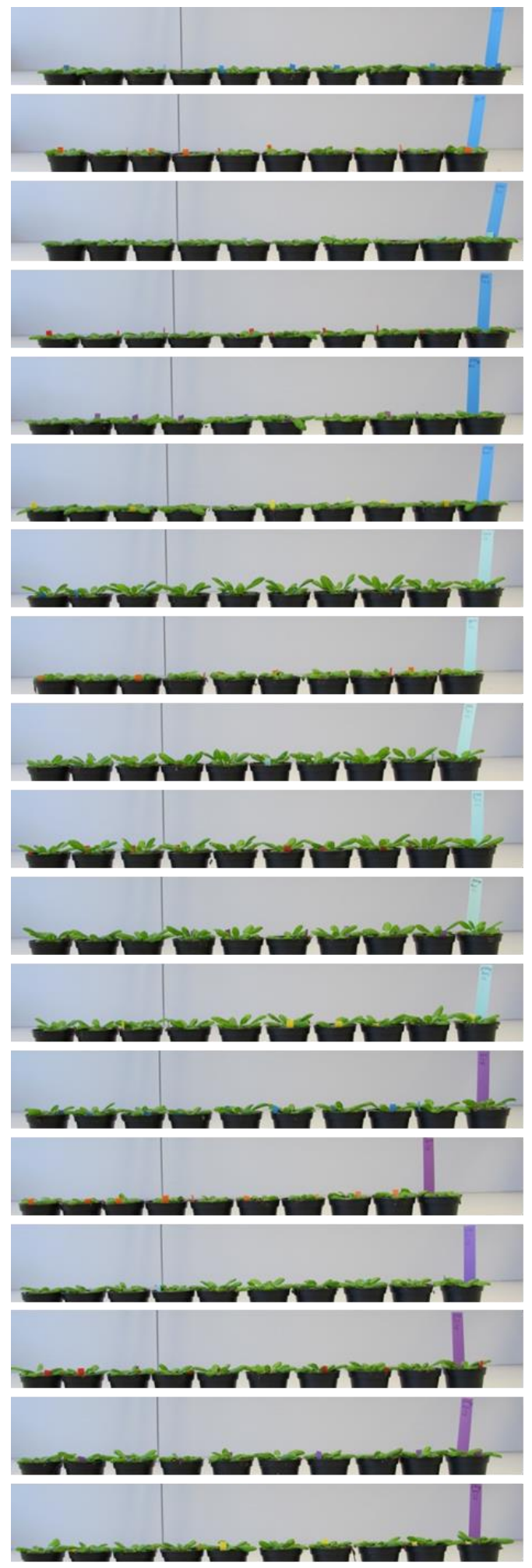

\begin{tabular}{ll} 
control light & wild-type \\
control light & tga1 tga4 \\
control light & gTGA1 \#1 \\
control light & gTGA1 \#3 \\
\hline control light & gTGA1cys \#1 \\
low light+SA & gTGA1cys \#3 \\
control light & gTGA1cys \#3 \\
\hline low light & gTGA1cys \#1 \\
\hline low light+SA & tga1 tga4 \\
\hline low light+SA & gTGA \\
\hline low light & wild-type \\
\hline low light & tga1 tga4 \\
\hline
\end{tabular}




\section{Supplementary Figure S11}

wild-type, tga 2 tga5 tga6, npr1, and 35S:HA-ROXY19 in response to 6 hours low light, low light plus $\mathrm{SA}$ treatment. Images were used for petiole angle measurement in Figure 3.5 .
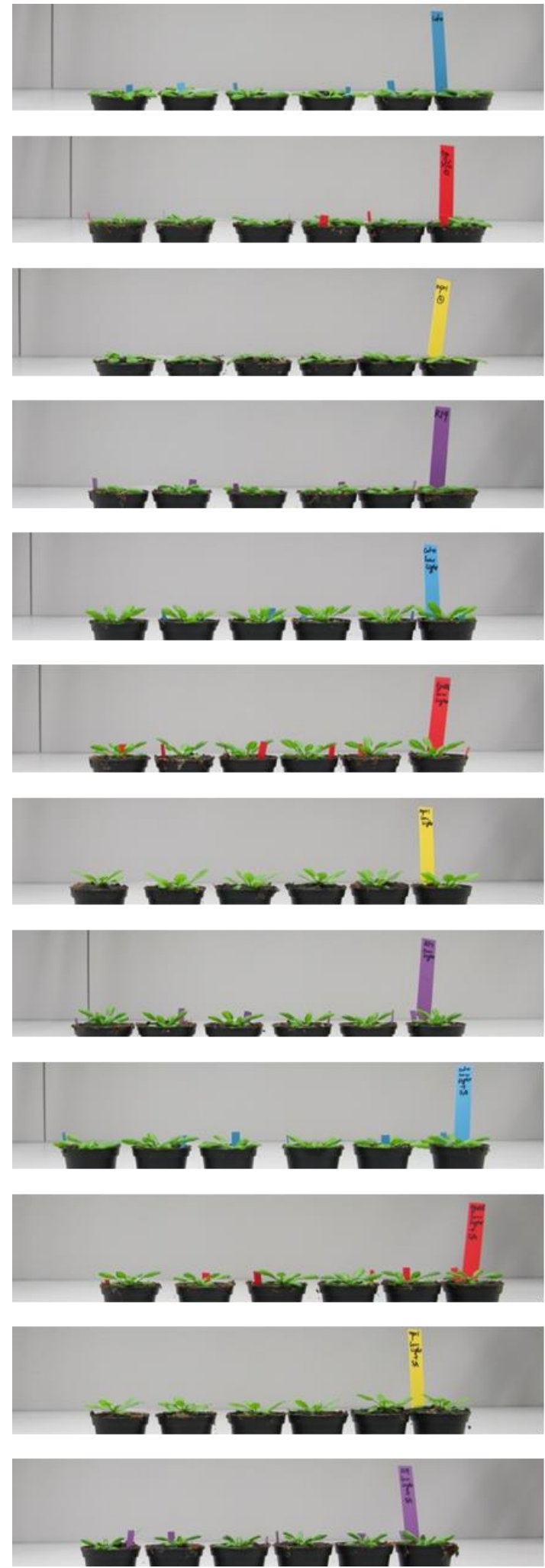

control light

control light

control light

control light

low light

low light

low light

low light

low light $+\mathrm{SA}$

low light+SA

low light+SA

low light+SA wild-type

$\operatorname{tga} 2$ tga 5 tga 6

npr1

ROXY19

wild-type

$\operatorname{tga} 2 \operatorname{tga} 5 \operatorname{tga} 6$

npr1

ROXY19

wild-type

$\operatorname{tga} 2 \operatorname{tga} 5$ tga 6

npr1

ROXY19 


\section{Supplementary Figure S12}

wild-type, tga1 tga4, gTGA1\#1, gTGA1\#3, gTGA1cys\#1 and gTGA1cys\#3 in response to low light, low light to control light treatment. Images were used for petiole angle measurement in Figure 3.6B.

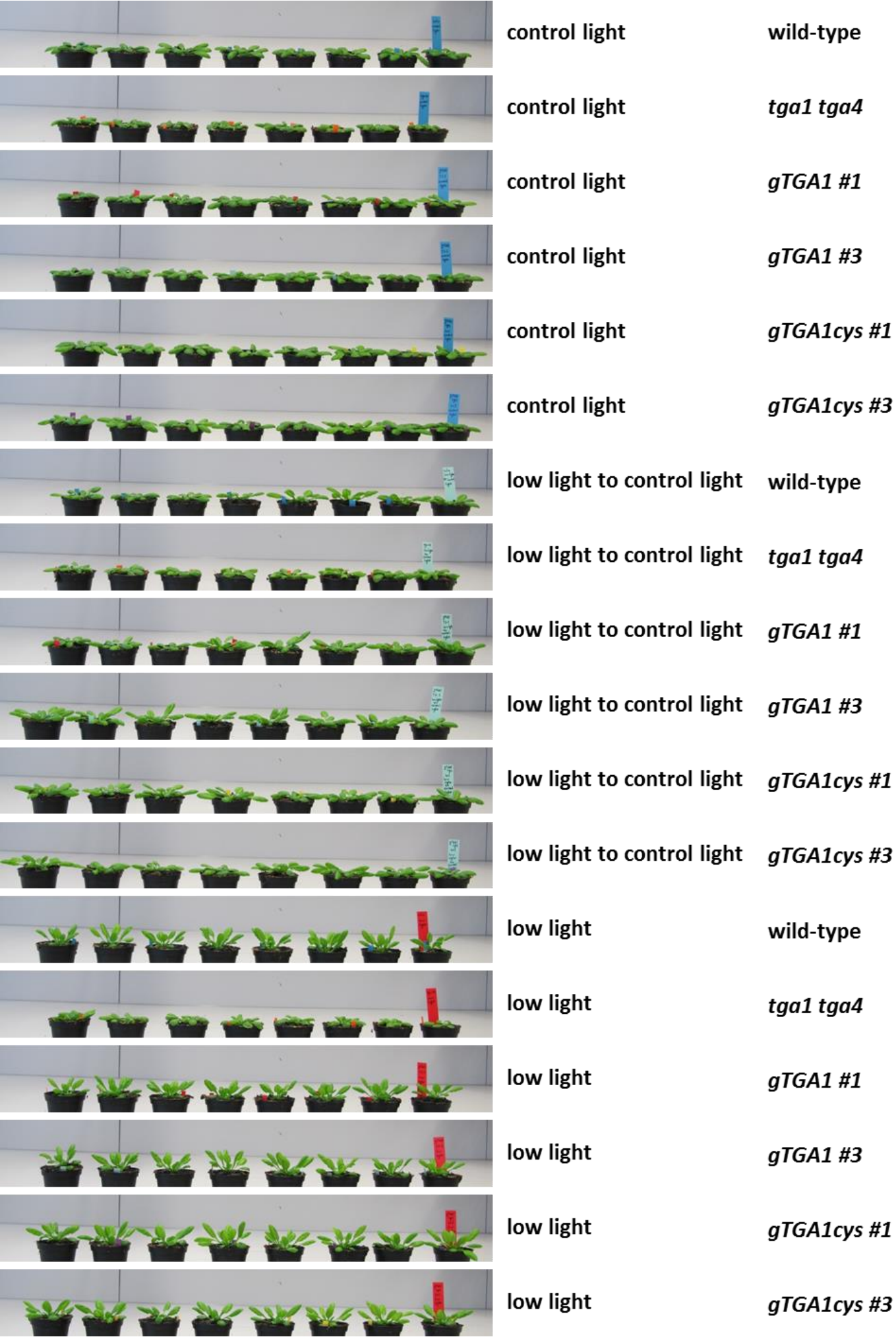




\section{Supplementary Figure S13}

wild-type, tga1 tga4, 35S:HA-ROXY8\#9,\#11,\#17,\#22,\#32 in response to 6 hours low light treatment. Images were used for petiole angle measurement in Figure 3.9A.

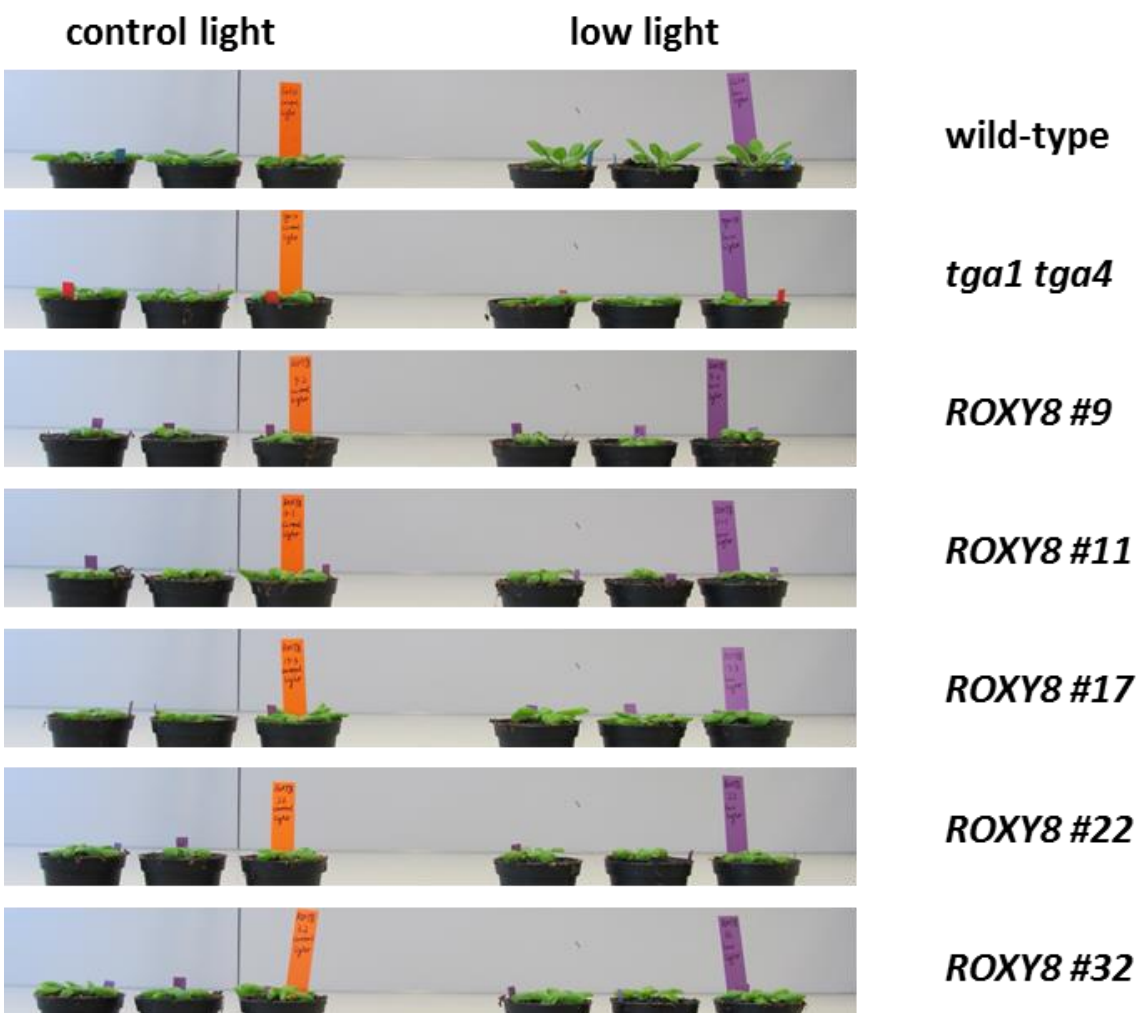


wild-type, tga1 tga4, 35S:HA-ROXY9\#6,\#7,\#10,\#13,\#14 in response to 6 hours low light treatment. Images were used for petiole angle measurement in Figure 3.9B.
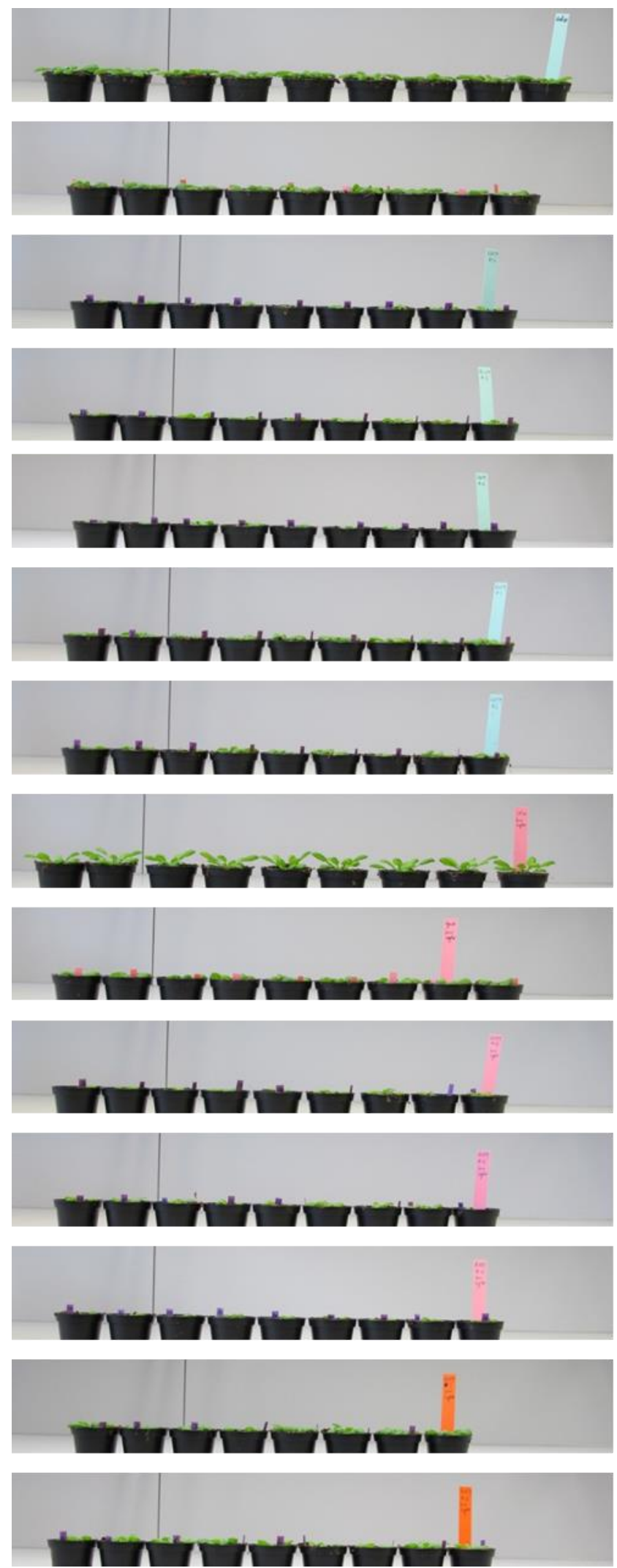

control light

control light

control light

control light

control light

control light

control light

low light

low light

low light

low light

low light

low light

low light wild-type

$\operatorname{tga} 1 \operatorname{tga} 4$

ROXY9 \#14

ROXY9 \#13

ROXY9 \#10

ROXY9 \#7

ROXY9 \#6

wild-type

$\operatorname{tga1} \operatorname{tga} 4$

ROXY9 \#14

ROXY9 \#13

ROXY9 \#10

ROXY9 \#7

ROXY9 \#6 
Table S1 List of 169 genes of cluster 2.

\begin{tabular}{|c|c|c|c|}
\hline Identifier & Description & $\begin{array}{l}\text { ColLL-tgaLL } \\
\text { logFC }\end{array}$ & $\begin{array}{l}\text { ColLL-ROXYLL } \\
\quad \operatorname{logFC}\end{array}$ \\
\hline AT5G25760 & 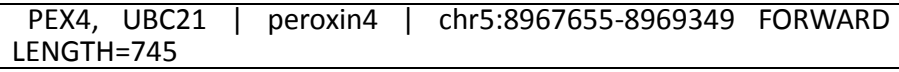 & 2.06 & 1.78 \\
\hline AT1G63380 & \begin{tabular}{cccc|} 
NAD(P)-binding & Rossmann-fold & superfamily & protein \\
chr1:23505557-23506391 FORWARD LENGTH=709 & & \\
\end{tabular} & 1.99 & 1.52 \\
\hline AT3G63440 & $\begin{array}{l}\text { ATCKX6, CKX6, ATCKX7 I cytokinin oxidase/dehydrogenase } 6 \text { । } \\
\text { chr3:23424157-23426536 FORWARD LENGTH=2007 }\end{array}$ & 1.95 & 2.39 \\
\hline AT3G49110 & \begin{tabular}{cccc|cc|} 
PRX33, & PRXCA, & ATPRX33, & ATPCA I I peroxidase & CA & I \\
chr3:18200664-18203142 FORWARD LENGTH $=1365$ & & & \\
\end{tabular} & 1.92 & 1.34 \\
\hline AT5G58390 & 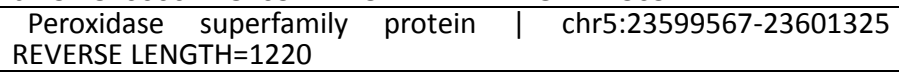 & 1.80 & 1.72 \\
\hline AT3G08840 & 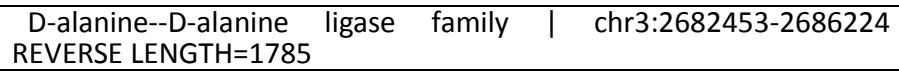 & 1.77 & 1.22 \\
\hline AT4G23450 & \begin{tabular}{cc|ccc|c} 
AIRP1, AtAIRP1 & RING/U-box & superfamily & protein & I \\
chr4:12240803-12242706 REVERSE LENGTH=1031 & & \\
\end{tabular} & 1.76 & 0.76 \\
\hline AT3G07610 & \begin{tabular}{c|c} 
IBM1 | Transcription factor jumonji (jmjC) domain-containing \\
protein | chr3:2426148-2432876 FORWARD LENGTH=3084
\end{tabular} & 1.75 & 0.85 \\
\hline AT5G66600 & $\begin{array}{l}\text { Protein of unknown function, DUF547 | chr5:26575000-26578826 } \\
\text { REVERSE LENGTH=2461 }\end{array}$ & 1.71 & 1.33 \\
\hline AT1G75920 & \begin{tabular}{cccc|} 
GDSL-like & Lipase/Acylhydrolase & superfamily & protein \\
chr1:28505554-28507168 FORWARD LENGTH=1106 & & \\
\end{tabular} & 1.68 & 2.28 \\
\hline AT5G17920 & $\begin{array}{l}\text { ATCIMS, ATMETS, ATMS1 | Cobalamin-independent synthase family } \\
\text { protein | chr5:5935038-5939487 FORWARD LENGTH=2771 }\end{array}$ & 1.61 & 1.25 \\
\hline AT1G37150 & $\begin{array}{l}\text { HCS2 I holocarboxylase synthetase } 2 \text { | chr1:14174981-14177302 } \\
\text { REVERSE LENGTH=1101 }\end{array}$ & 1.56 & 0.59 \\
\hline AT5G03545 & $\begin{array}{l}\text { AT4, ATIPS2 | Expressed in response to phosphate starvation, this } \\
\text { response is enhanced by the presence of IAA. | chr5:894706-895400 } \\
\text { FORWARD LENGTH=695 }\end{array}$ & 1.53 & 1.83 \\
\hline AT1G56600 & $\begin{array}{l}\text { AtGolS2, GolS2 | galactinol synthase } 2 \text { | chr1:21207537-21209596 } \\
\text { FORWARD LENGTH=1396 }\end{array}$ & 1.53 & 1.32 \\
\hline AT4G21160 & \begin{tabular}{c|ccc} 
ZAC & $\begin{array}{c}\text { Calcium-dependent ARF-type GTPase activating } \\
\text { family }\end{array}$ & chr4:11284238-11286767 FORWARD LENGTH=1404 & \\
\end{tabular} & 1.53 & 0.47 \\
\hline AT1G28290 & $\begin{array}{l}\text { AGP31 | arabinogalactan protein 31 | chr1:9889125-9890875 } \\
\text { REVERSE LENGTH=1186 }\end{array}$ & 1.52 & 1.49 \\
\hline AT1G15860 & $\begin{array}{l}\text { Domain of unknown function (DUF298) | chr1:5454838-5457022 } \\
\text { FORWARD LENGTH=1182 }\end{array}$ & 1.52 & 1.95 \\
\hline AT3G26960 & \begin{tabular}{cccccccc|}
$\begin{array}{c}\text { Pollen Ole } \\
\text { chr3:9944668-9945579 REVERSE LENGTH=836 }\end{array}$ & allergen and extensin family & protein & & \\
\end{tabular} & 1.48 & 1.68 \\
\hline AT5G66420 & $\begin{array}{l}\text { CONTAINS InterPro DOMAIN/s: Uncharacterised conserved protein } \\
\text { UCP033271 (InterPro:IPRO08322), TIM-barrel signal transduction } \\
\text { protein, predicted (InterPro:IPRO09215); Has } 30201 \text { Blast hits to } \\
17322 \text { proteins in } 780 \text { species: Archae - 12; Bacteria - 1396; Metazoa } \\
\text { - } 17338 \text {; Fungi - } 3422 \text {; Plants - 5037; Viruses - 0; Other Eukaryotes - } \\
\text { 2996 (source: NCBI BLink). I chr5:26521674-26525029 REVERSE } \\
\text { LENGTH=2679 }\end{array}$ & 1.47 & 2.10 \\
\hline AT3G25010 & $\begin{array}{l}\text { AtRLP41, RLP41 | receptor like protein } 41 \text { | chr3:9110103-9112748 } \\
\text { REVERSE LENGTH=2646 }\end{array}$ & 1.46 & 1.02 \\
\hline AT5G22820 & $\begin{array}{l}\text { ARM repeat superfamily protein | chr5:7623440-7626975 REVERSE } \\
\text { LENGTH=1997 }\end{array}$ & 1.46 & 1.59 \\
\hline AT3G15605 & \begin{tabular}{cc|cc}
$\begin{array}{c}\text { nucleic } \\
\text { LENGTH }=1667\end{array}$ & binding & chr3:5288093-5290941 & FORWARD \\
\end{tabular} & 1.43 & 0.87 \\
\hline AT2G21540 & $\begin{array}{l}\text { ATSFH3, SFH3 | SEC14-like } 3 \text { | chr2:9220556-9224496 REVERSE } \\
\text { LENGTH=2106 }\end{array}$ & 1.43 & 1.57 \\
\hline AT3G61880 & $\begin{array}{l}\text { CYP78A9 | cytochrome p450 78a9 | chr3:22905868-22907958 } \\
\text { REVERSE LENGTH=1919 }\end{array}$ & 1.42 & 2.15 \\
\hline AT5G42690 & $\begin{array}{l}\text { Protein of unknown function, DUF547 | chr5:17116428-17119838 } \\
\text { REVERSE LENGTH=2102 }\end{array}$ & 1.41 & 0.53 \\
\hline AT3G46490 & $\begin{array}{l}\text { 2-oxoglutarate (2OG) and Fe(II)-dependent oxygenase superfamily } \\
\text { protein | chr3:17115629-17119451 FORWARD LENGTH=993 }\end{array}$ & 1.39 & 0.74 \\
\hline AT4G35900 & $\begin{array}{l}\text { FD, FD-1, atbzip14 | Basic-leucine zipper (bZIP) transcription factor } \\
\text { family protein | chr4:17004595-17006287 FORWARD LENGTH=1344 }\end{array}$ & 1.37 & 0.89 \\
\hline AT4G25090 & $\begin{array}{ccccc}\text { Riboflavin } & \text { synthase-like } & \text { superfamily } & \text { protein } & \text { | } \\
\text { chr4:12878775-12883599 REVERSE LENGTH=2705 } & & \\
\end{array}$ & 1.37 & 0.69 \\
\hline AT2G22620 & $\begin{array}{l}\text { Rhamnogalacturonate lyase family protein | chr2:9604772-9610595 } \\
\text { REVERSE LENGTH }=2444\end{array}$ & 1.36 & 1.25 \\
\hline AT1G58225 & $\begin{array}{l}\text { unknown protein; FUNCTIONS IN: molecular_function unknown; } \\
\text { INVOLVED IN: biological_process unknown; LOCATED IN: } \\
\text { endomembrane system; Has 4 Blast hits to } 4 \text { proteins in } 2 \text { species: } \\
\text { Archae - 0; Bacteria - 0; Metazoa - 0; Fungi - 0; Plants - 4; Viruses - 0; } \\
\text { Other Eukaryotes - } \quad 0 \quad \text { (source: NCBI BLink). } \\
\text { chr1:21564111-21565171 FORWARD LENGTH }=702\end{array}$ & 1.33 & 1.17 \\
\hline
\end{tabular}




\begin{tabular}{|c|c|c|c|}
\hline Identifier & Description & $\begin{array}{l}\text { ColLL-tgaLL } \\
\text { logFC }\end{array}$ & $\begin{array}{l}\text { CoILL-ROXYLL } \\
\text { logFC }\end{array}$ \\
\hline AT4G18970 & 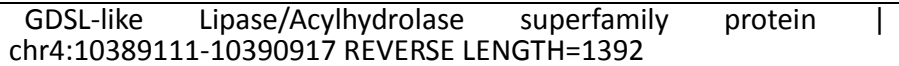 & 1.32 & 0.57 \\
\hline AT4G01680 & $\begin{array}{l}\text { MYB55 | myb domain protein } 55 \text { | chr4:716021-717415 REVERSE } \\
\text { LENGTH=1248 }\end{array}$ & 1.31 & 1.21 \\
\hline AT2G21050 & $\begin{array}{l}\text { LAX2 | like AUXIN RESISTANT } 2 \text { | chr2:9034090-9036636 FORWARD } \\
\text { LENGTH=1848 }\end{array}$ & 1.31 & 1.52 \\
\hline AT1G53040 & $\begin{array}{l}\text { Protein of unknown function (DUF616) | chr1:19764310-19767334 } \\
\text { REVERSE LENGTH=2174 }\end{array}$ & 1.30 & 1.22 \\
\hline AT1G10657 & $\begin{array}{l}\text { Plant protein } 1589 \text { of unknown function | chr1:3530467-3531821 } \\
\text { FORWARD LENGTH=862 }\end{array}$ & 1.29 & 0.76 \\
\hline AT2G34655 & $\begin{array}{l}\text { unknown protein; FUNCTIONS IN: molecular_function unknown; } \\
\text { INVOLVED IN: biological_process unknown; LOCATED IN: } \\
\text { endomembrane system; EXPRESSED IN: stem, root, inflorescence, } \\
\text { cultured cell, leaf; Has } 35333 \text { Blast hits to } 34131 \text { proteins in 2444 } \\
\text { species: Archae - 798; Bacteria - } 22429 \text {; Metazoa - 974; Fungi - 991; } \\
\text { Plants - 531; Viruses - 0; Other Eukaryotes - } 9610 \text { (source: NCBI } \\
\text { BLink). | chr2:14596631-14597540 FORWARD LENGTH=910 }\end{array}$ & 1.26 & 1.45 \\
\hline AT4G00440 & $\begin{array}{l}\text { Protein of unknown function (DUF3741) | chr4:193879-198579 } \\
\text { FORWARD LENGTH=3802 }\end{array}$ & 1.26 & 1.48 \\
\hline AT1G68810 & $\begin{array}{l}\text { basic helix-loop-helix (bHLH) DNA-binding superfamily protein I } \\
\text { chr1:25861123-25863120 FORWARD LENGTH }=1511\end{array}$ & 1.25 & 1.35 \\
\hline AT5G12880 & $\begin{array}{c}\begin{array}{c}\text { proline-rich family protein | chr5:4068519-4068962 } \\
\text { LENGTH=444 }\end{array} \\
\end{array}$ & 1.25 & 0.91 \\
\hline AT5G09220 & $\begin{array}{l}\text { AAP2 | amino acid permease } 2 \mid \text { chr5:2866252-2869054 FORWARD } \\
\text { LENGTH=1794 }\end{array}$ & 1.24 & 1.13 \\
\hline AT4G02290 & \begin{tabular}{cc|cc|c} 
AtGH9B13, & GH9B13 & glycosyl hydrolase & 9B13 \\
chr4:1002394-1005253 REVERSE LENGTH=1939 & & \\
\end{tabular} & 1.24 & 1.66 \\
\hline AT5G05960 & $\begin{array}{l}\text { Bifunctional inhibitor/lipid-transfer protein/seed storage } 2 \mathrm{~S} \\
\text { albumin superfamily protein | chr5:1790231-1790833 FORWARD } \\
\text { LENGTH=515 }\end{array}$ & 1.23 & 1.38 \\
\hline AT3G20080 & \begin{tabular}{c|cccc} 
CYP705A15 I cytochrome P450, family 705, subfamily A, & A, \\
polypeptide 15 | chr3:7008774-7010677 FORWARD LENGTH=1825
\end{tabular} & 1.23 & 1.13 \\
\hline AT3G20460 & $\begin{array}{l}\text { Major facilitator superfamily protein | chr3:7135050-7139472 } \\
\text { FORWARD LENGTH=1470 }\end{array}$ & 1.23 & 1.30 \\
\hline AT5G46240 & \begin{tabular}{c|ccccc} 
KAT1 I potassium channel in Arabidopsis thaliana & 1 & I \\
chr5:18743566-18746730 REVERSE LENGTH=2289 & & &
\end{tabular} & 1.23 & 1.16 \\
\hline AT3G06370 & \begin{tabular}{cc|cccc|}
$\begin{array}{c}\text { NHX4, } \\
\text { chr3:1930396-1934073 REVERSE LENGTH=2207 }\end{array}$ & exchanger & 4 & I \\
\end{tabular} & 1.22 & 1.43 \\
\hline AT5G23210 & $\begin{array}{l}\text { SCPL34 | serine carboxypeptidase-like } 34 \text { | chr5:7810855-7815039 } \\
\text { FORWARD LENGTH=1848 }\end{array}$ & 1.22 & 1.44 \\
\hline AT3G12610 & \begin{tabular}{c|cccc} 
DRT100 I & Leucine-rich repeat & (LRR) family & protein & I \\
chr3:4006399-4007807 REVERSE LENGTH=1409 & & & \\
\end{tabular} & 1.21 & 1.29 \\
\hline AT2G40610 & $\begin{array}{l}\text { ATEXPA8, EXP8, ATEXP8, ATHEXP ALPHA 1.11, EXPA8 | expansin A8 | } \\
\text { chr2:16948863-16950557 REVERSE LENGTH=1105 }\end{array}$ & 1.20 & 1.36 \\
\hline AT1G18710 & 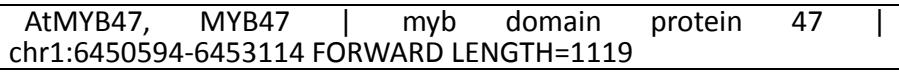 & 1.19 & 0.92 \\
\hline AT5G54510 & \begin{tabular}{cc|ccc|} 
GH3.6, & DFL1 & Auxin-responsive & GH3 family & protein \\
chr5:22131093-22133678 REVERSE LENGTH=2181 & & \\
\end{tabular} & 1.18 & 1.52 \\
\hline AT3G28700 & $\begin{array}{l}\text { Protein of unknown function (DUF185) | chr3:10759559-10762114 } \\
\text { FORWARD LENGTH=1717 }\end{array}$ & 1.17 & 1.19 \\
\hline AT1G23340 & $\begin{array}{l}\text { Protein of Unknown Function (DUF239) | chr1:8283644-8286528 } \\
\text { REVERSE LENGTH=1289 }\end{array}$ & 1.17 & 1.15 \\
\hline AT1G23140 & $\begin{array}{l}\text { Calcium-dependent lipid-binding (CaLB domain) family protein I } \\
\text { chr1:8202261-8203215 REVERSE LENGTH=642 }\end{array}$ & 1.17 & 0.89 \\
\hline AT2G14680 & $\begin{array}{l}\text { MEE13 I myosin heavy chain-related I chr2:6277961-6283940 } \\
\text { FORWARD LENGTH=2359 }\end{array}$ & 1.16 & 1.06 \\
\hline AT3G25620 & $\begin{array}{l}\text { ABC-2 type transporter family protein | chr3:9316074-9319571 } \\
\text { REVERSE LENGTH=2688 }\end{array}$ & 1.16 & 1.14 \\
\hline AT1G78970 & $\begin{array}{l}\text { LUP1, ATLUP1 | lupeol synthase } 1 \text { | chr1:29703062-29707844 } \\
\text { FORWARD LENGTH=2642 }\end{array}$ & 1.15 & 1.85 \\
\hline AT4G08040 & \begin{tabular}{c|rlcl|} 
ACS11 I-aminocyclopropane-1-carboxylate & synthase & 11 & I \\
chr4:4887112-4888939 FORWARD LENGTH=1383 & & & & \\
\end{tabular} & 1.14 & 0.99 \\
\hline AT3G48900 & $\begin{array}{ccccc}\text { single-stranded } & \text { DNA } & \text { endonuclease } & \text { family } & \text { protein } \\
\text { chr3:18131829-18136341 FORWARD LENGTH }=2031 & & \\
\end{array}$ & 1.13 & 1.79 \\
\hline AT3G15540 & $\begin{array}{cccccc}\text { IAA19, MSG2 I } & \text { indole-3-acetic acid } \\
\text { chr3:5264024-5265678 FORWARD LENGTH=970 }\end{array}$ & 1.13 & 1.37 \\
\hline AT2G46570 & \begin{tabular}{c|cc|cc} 
LAC6 & laccase & 6 & l chr2:19126872-19129069 & FORWARD \\
LENGTH=1710 & & & \\
\end{tabular} & 1.12 & 0.75 \\
\hline AT5G10430 & $\begin{array}{l}\text { AGP4, ATAGP4 | arabinogalactan protein } 4 \text { | chr5:3277532-3278313 } \\
\text { REVERSE LENGTH=782 }\end{array}$ & 1.11 & 1.85 \\
\hline AT2G24300 & $\begin{array}{l}\text { Calmodulin-binding protein | chr2:10340816-10343736 FORWARD } \\
\text { LENGTH=2214 }\end{array}$ & 1.10 & 1.02 \\
\hline
\end{tabular}




\begin{tabular}{|c|c|c|c|}
\hline Identifier & Description & $\begin{array}{l}\text { ColLL-tgaLL } \\
\text { logFC }\end{array}$ & $\begin{array}{l}\text { ColLL-ROXYLL } \\
\text { IOgFC }\end{array}$ \\
\hline AT1G75780 & $\begin{array}{l}\text { TUB1 | tubulin beta-1 chain | chr1:28451141-28453640 REVERSE } \\
\text { LENGTH=1619 }\end{array}$ & 1.09 & 1.21 \\
\hline AT2G18690 & $\begin{array}{l}\text { unknown protein; FUNCTIONS IN: molecular_function unknown; } \\
\text { INVOLVED IN: biological_process unknown; LOCATED IN: membrane; } \\
\text { EXPRESSED IN: } 17 \text { plant structures; EXPRESSED DURING: } 9 \text { growth } \\
\text { stages; CONTAINS InterPro DOMAIN/s: Protein of unknown function } \\
\text { DUF975 (InterPro:IPR010380); BEST Arabidopsis thaliana protein } \\
\text { match is: unknown protein (TAIR:AT2G18680.1); Has } 213 \text { Blast hits to } \\
211 \text { proteins in } 20 \text { species: Archae - 0; Bacteria - 8; Metazoa - 0; } \\
\text { Fungi - 0; Plants - 205; Viruses - 0; Other Eukaryotes - } 0 \text { (source: NCBI } \\
\text { BLink). I chr2:8097420-8098827 FORWARD LENGTH=1408 }\end{array}$ & 1.07 & 1.10 \\
\hline AT3G54260 & \begin{tabular}{c|cccc} 
TBL36 I & TRICHOME & BIREFRINGENCE-LIKE & 36 & | \\
chr3:20085010-20086763 REVERSE LENGTH=1245 & & & \\
\end{tabular} & 1.07 & 0.84 \\
\hline AT1G80660 & $\begin{array}{l}\text { AHA9, HA9 | H(+)-ATPase } 9 \mid \text { chr1:30316227-30319948 REVERSE } \\
\text { LENGTH=2865 }\end{array}$ & 1.06 & 1.14 \\
\hline AT5G06930 & $\begin{array}{l}\text { LOCATED IN: chloroplast; EXPRESSED IN: } 15 \text { plant structures; } \\
\text { EXPRESSED DURING: } 7 \text { growth stages; BEST Arabidopsis thaliana } \\
\text { protein match is: nucleolar protein gar2-related (TAIR:AT2G42320.2); } \\
\text { Has } 3369 \text { Blast hits to } 1526 \text { proteins in } 313 \text { species: Archae - 2; } \\
\text { Bacteria - } 910 ; \text {;etazoa - } 754 \text {; Fungi - } 336 \text {; Plants - } 137 \text {; Viruses - 11; } \\
\text { Other Eukaryotes - } 1219 \quad \text { (source: NCBI BLink). } \\
\text { chr5:2144999-2148039 FORWARD LENGTH=2502 }\end{array}$ & 1.06 & 1.26 \\
\hline AT2G34300 & 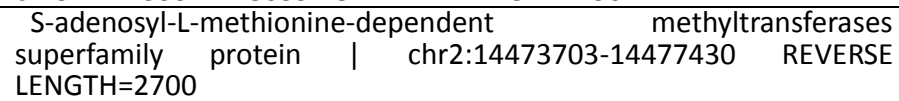 & 1.05 & 1.93 \\
\hline AT1G23060 & $\begin{array}{l}\text { BEST Arabidopsis thaliana protein match is: TPX2 (targeting protein } \\
\text { for Xklp2) protein family (TAIR:AT1G70950.1); Has } 449 \text { Blast hits to } \\
419 \text { proteins in } 98 \text { species: Archae - 0; Bacteria - 40; Metazoa - 139; } \\
\text { Fungi - 21; Plants - 158; Viruses - 3; Other Eukaryotes - } 88 \text { (source: } \\
\text { NCBI BLink). | chr1:8170755-8172992 REVERSE LENGTH } 1452\end{array}$ & 1.05 & 1.44 \\
\hline AT2G46320 & $\begin{array}{ccccc}\begin{array}{c}\text { Mitochondrial substrate carrier family } \\
\text { chr2:19015813-19018230 FORWARD LENGTH=1497 }\end{array} & \text { protein } & \\
\end{array}$ & 1.05 & 1.31 \\
\hline AT5G18080 & $\begin{array}{l}\text { SAUR-like auxin-responsive protein family chr5:5983840-5984112 } \\
\text { FORWARD LENGTH=273 }\end{array}$ & 1.05 & 1.49 \\
\hline AT1G19530 & $\begin{array}{l}\text { unknown protein; FUNCTIONS IN: molecular_function unknown; } \\
\text { INVOLVED IN: N-terminal protein myristoylation, anaerobic } \\
\text { respiration; LOCATED IN: cellular_component unknown; EXPRESSED } \\
\text { IN: leaf apex, inflorescence meristem, hypocotyl, root, flower; } \\
\text { EXPRESSED DURING: petal differentiation and expansion stage; Has } \\
47 \text { Blast hits to } 47 \text { proteins in } 13 \text { species: Archae - } 0 \text {; Bacteria - } 0 \text {; } \\
\text { Metazoa - } 0 \text {; Fungi - } 0 \text {; Plants - } 47 \text {; Viruses - } 0 \text {; Other Eukaryotes - } 0 \\
\text { (source: NCBI BLink). I chr1:6763915-6764971 FORWARD } \\
\text { LENGTH=700 }\end{array}$ & 1.04 & 1.56 \\
\hline AT3G11720 & $\begin{array}{l}\text { Polyketide cyclase/dehydrase and lipid transport superfamily } \\
\text { protein | chr3:3705865-3708609 REVERSE LENGTH=1947 }\end{array}$ & 1.04 & 1.23 \\
\hline AT2G10606 & $\begin{array}{l}\text { MIR396A | MIR396A; miRNA | chr2:4142323-4142473 REVERSE } \\
\text { LENGTH=151 }\end{array}$ & 1.03 & 1.21 \\
\hline AT3G25710 & \begin{tabular}{cc|ccc|}
$\begin{array}{c}\text { BHLH32, ATAIG1, TMO5 I basic helix-loop-helix } \\
\text { chr3:9369519-9371394 FORWARD LENGTH }=1412\end{array}$ & & \\
\end{tabular} & 1.03 & 0.95 \\
\hline AT5G14230 & $\begin{array}{l}\text { CONTAINS InterPro DOMAIN/s: Ankyrin repeat-containing domain } \\
\text { (InterPro:IPRO20683), Ankyrin repeat (InterPro:IPRO02110); BEST } \\
\text { Arabidopsis thaliana protein match is: XB3 ortholog } 2 \text { in Arabidopsis } \\
\text { thaliana (TAIR:AT5G57740.1); Has } 66374 \text { Blast hits to } 25358 \text { proteins } \\
\text { in } 1201 \text { species: Archae - 121; Bacteria - 8133; Metazoa - 29530; } \\
\text { Fungi - 5885; Plants - 3349; Viruses - 785; Other Eukaryotes - } 18571 \\
\text { (source: NCBI BLink). I chr5:4591741-4595964 FORWARD } \\
\text { LENGTH=2587 }\end{array}$ & 1.02 & 0.93 \\
\hline AT3G62090 & \begin{tabular}{cc|cccc} 
PIL2, & PIF6 I phytochrome interacting factor & 3-like & 2 & I \\
chr3:22 $2988547-22990709$ & REVERSE LENGTH $=1805$ & & & \\
\end{tabular} & 1.02 & 0.71 \\
\hline AT2G40130 & $\begin{array}{l}\text { Double Clp-N motif-containing P-loop nucleoside triphosphate } \\
\text { hydrolases superfamily protein | chr2:16765920-16769268 } \\
\text { FORWARD LENGTH=3037 }\end{array}$ & 1.02 & 1.37 \\
\hline AT1G78970 & $\begin{array}{l}\text { LUP1, ATLUP1 | lupeol synthase } 1 \text { | chr1:29703340-29707844 } \\
\text { FORWARD LENGTH=2477 }\end{array}$ & 1.01 & 1.47 \\
\hline AT1G67750 & $\begin{array}{l}\text { Pectate lyase family protein | chr1:25401588-25403503 FORWARD } \\
\text { LENGTH=1637 }\end{array}$ & 1.01 & 1.55 \\
\hline AT2G47000 & $\begin{array}{l}\text { MDR4, PGP4, ABCB4, ATPGP4 | ATP binding cassette subfamily B4 | } \\
\text { chr2:19309868-19315241 REVERSE LENGTH }=4161\end{array}$ & 1.01 & 0.89 \\
\hline AT3G23030 & $\begin{array}{l}\text { IAA2 | indole-3-acetic acid inducible } 2 \text { | chr3:8180768-8181800 } \\
\text { REVERSE LENGTH=941 }\end{array}$ & 1.00 & 1.32 \\
\hline AT1G25530 & $\begin{array}{c}\text { Transmembrane amino acid transporter } \\
\text { chr1:8964544-8967428 REVERSE LENGTH }=1643\end{array}$ & 1.00 & 1.21 \\
\hline AT1G52750 & $\begin{array}{ccc}\text { alpha/beta-Hydrolases } & \text { superfamily } & \text { protein } \\
\text { chr1:19646465-19649261 REVERSE LENGTH=2275 } & \end{array}$ & 1.00 & 1.55 \\
\hline
\end{tabular}




\begin{tabular}{|c|c|c|c|}
\hline Identifier & Description & $\begin{array}{l}\text { ColLL-tgaLL } \\
\text { logFC }\end{array}$ & $\begin{array}{l}\text { ColLL-ROXYLL } \\
\text { logFC }\end{array}$ \\
\hline AT5G57150 & $\begin{array}{l}\text { basic helix-loop-helix (bHLH) DNA-binding superfamily protein I } \\
\text { chr5:23152186-23154264 FORWARD LENGTH }=1827\end{array}$ & 0.99 & 0.70 \\
\hline AT1G11120 & $\begin{array}{l}\text { Unknown protein; FUNCTIONS IN: molecular_function unknown; } \\
\text { INVOLVED IN: biological_process unknown; LOCATED IN: } \\
\text { cellular_component unknown; EXPRESSED IN: } 10 \text { plant structures; } \\
\text { EXPRESSED DURING: } 4 \text { anthesis, F mature embryo stage, petal } \\
\text { differentiation and expansion stage, E expanded cotyledon stage, D } \\
\text { bilateral stage; BEST Arabidopsis thaliana protein match is: unknown } \\
\text { protein (TAIR:AT4G28170.1); Has } 94 \text { Blast hits to } 94 \text { proteins in } 13 \\
\text { species: Archae - 0; Bacteria - 0; Metazoa - 0; Fungi - 0; Plants - 94; } \\
\text { Viruses - 0; Other Eukaryotes - } 0 \text { (source: NCBI BLink). I } \\
\text { chr1:3715184-3717320 FORWARD LENGTH=531 }\end{array}$ & 0.99 & 1.36 \\
\hline AT4G39800 & \begin{tabular}{lcccc|} 
MI-1-P SYNTHASE, & MIPS1, & ATMIPS1, ATIPS1 \\
myo-inositol-1-phosphate & synthase & 1 & I chr4:18469348-18471967 \\
REVERSE LENGTH=1921 & & & & \\
\end{tabular} & 0.99 & 0.91 \\
\hline AT1G63300 & $\begin{array}{l}\text { Myosin heavy chain-related protein | chr1:23482193-23486220 } \\
\text { FORWARD LENGTH }=3243\end{array}$ & 0.99 & 0.93 \\
\hline AT4G16260 & $\begin{array}{l}\text { Glycosyl hydrolase superfamily protein | chr4:9200010-9201552 } \\
\text { REVERSE LENGTH=1316 }\end{array}$ & 0.98 & 0.98 \\
\hline AT1G52190 & $\begin{array}{l}\text { Major facilitator superfamily protein | chr1:19434509-19438971 } \\
\text { FORWARD LENGTH =2284 }\end{array}$ & 0.98 & 0.97 \\
\hline AT1G67260 & $\begin{array}{l}\text { TCP1 I TCP family transcription factor chr1:25167462-25169307 } \\
\text { REVERSE LENGTH=1307 }\end{array}$ & 0.98 & 0.98 \\
\hline AT1G26945 & $\begin{array}{c}\text { KDR I basic helix-loop-helix (bHLH) } \text { DNA-binding superfamily } \\
\text { protein | chr1:9351454-9352761 FORWARD LENGTH=689 }\end{array}$ & 0.98 & 2.10 \\
\hline AT5G55550 & $\begin{array}{ccccc}\text { RNA-binding } & \text { (RRM/RBD/RNP } & \text { motifs) family } & \text { protein } \\
\text { chr5:22502064-22504011 REVERSE LENGTH }=1640 & & \\
\end{array}$ & 0.97 & 0.67 \\
\hline AT3G28420 & \begin{tabular}{cc|c}
$\begin{array}{c}\text { Putative } \\
\text { REVERSE LENGTH=919 }\end{array}$ & lipoprotein & chr3:10654470-10655388 \\
\end{tabular} & 0.97 & 1.88 \\
\hline AT3G17185 & 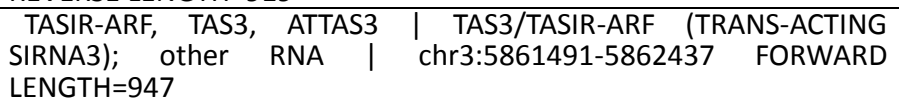 & 0.97 & 0.61 \\
\hline AT4G32460 & $\begin{array}{l}\text { Protein of unknown function, DUF642 | chr4:15662266-15664948 } \\
\text { REVERSE LENGTH=1257 }\end{array}$ & 0.96 & 1.52 \\
\hline AT1G76960 & $\begin{array}{l}\text { unknown protein; FUNCTIONS IN: molecular_function unknown; } \\
\text { INVOLVED IN: biological_process unknown; LOCATED IN: } \\
\text { endomembrane system; EXPRESSED IN: } 9 \text { plant structures; } \\
\text { EXPRESSED DURING: } 8 \text { growth stages; Has } 8 \text { Blast hits to } 8 \text { proteins in } \\
2 \text { species: Archae - 0; Bacteria - 0; Metazoa - 0; Fungi - 0; Plants - 8; } \\
\text { Viruses - 0; Other Eukaryotes - } 0 \text { (source: NCBI BLink). I } \\
\text { chr1:28920457-28920956 REVERSE LENGTH=388 }\end{array}$ & 0.96 & 0.99 \\
\hline AT1G78040 & $\begin{array}{cccccc}\text { Pollen Ole } & \text { e } & 1 & \text { allergen and extensin family } & \text { protein } \\
\text { chr1:29345838-29347107 FORWARD LENGTH }=938\end{array}$ & 0.96 & 0.86 \\
\hline AT1G53800 & $\begin{array}{l}\text { unknown protein; BEST Arabidopsis thaliana protein match is: } \\
\text { unknown protein (TAIR:AT1G53250.1); Has } 1136 \text { Blast hits to } 882 \\
\text { proteins in } 242 \text { species: Archae - 2; Bacteria - 216; Metazoa - 257; } \\
\text { Fungi - 77; Plants - 87; Viruses - 4; Other Eukaryotes - } 493 \text { (source: } \\
\text { NCBI BLink). | chr1:20081730-20084500 FORWARD LENGTH=2045 }\end{array}$ & 0.96 & 1.23 \\
\hline AT5G50335 & $\begin{array}{l}\text { unknown protein; Has } 30201 \text { Blast hits to } 17322 \text { proteins in } 780 \\
\text { species: Archae - 12; Bacteria - 1396; Metazoa - } 17338 \text {; Fungi - } 3422 \text {; } \\
\text { Plants - 5037; Viruses - 0; Other Eukaryotes - } 2996 \text { (source: NCBI } \\
\text { BLink). | chr5:20489094-20489727 REVERSE LENGTH=634 }\end{array}$ & 0.96 & 0.90 \\
\hline AT4G30180 & $\begin{array}{l}\text { sequence-specific DNA binding transcription factors; transcription } \\
\text { regulators | chr4:14768936-14769648 FORWARD LENGTH }=713\end{array}$ & 0.95 & 1.04 \\
\hline AT4G09890 & $\begin{array}{l}\text { Protein of unknown function (DUF3511) | chr4:6218396-6218927 } \\
\text { FORWARD LENGTH=532 }\end{array}$ & 0.95 & 0.87 \\
\hline AT1G60960 & \begin{tabular}{cc|cccc} 
IRT3, ATIRT3 I & iron $\begin{array}{c}\text { regulated transporter } \\
\text { chr1:22445310-22447214 }\end{array}$ REVERSE LENGTH=1532 & 3 & I \\
\end{tabular} & 0.95 & 0.63 \\
\hline AT4G11830 & $\begin{array}{l}\text { PLDGAMMA2 | phospholipase D gamma } 2 \text { | chr4:7115736-7121245 } \\
\text { REVERSE LENGTH=3820 }\end{array}$ & 0.95 & 1.41 \\
\hline AT4G14130 & $\begin{array}{l}\text { XTR7, XTH15 | xyloglucan endotransglucosylase/hydrolase } 15 \text { | } \\
\text { chr4:8137051-8138281 REVERSE LENGTH=1065 }\end{array}$ & 0.95 & 0.72 \\
\hline AT1G11545 & \begin{tabular}{c|ccc} 
XTH8 I xyloglucan endotransglucosylase/hydrolase & 8 & | \\
chr1:3878550-3880361 REVERSE LENGTH=1132 & & &
\end{tabular} & 0.94 & 1.14 \\
\hline AT1G64670 & \begin{tabular}{c|ccc} 
BDG1 | alpha/beta-Hydrolases superfamily & protein \\
chr1:24030820-24033556 REVERSE LENGTH=1662 & &
\end{tabular} & 0.94 & 0.96 \\
\hline AT2G44500 & $\begin{array}{l}\text { O-fucosyltransferase family protein | chr2:18374292-18376790 } \\
\text { FORWARD LENGTH=2311 }\end{array}$ & 0.94 & 0.76 \\
\hline AT5G48900 & $\begin{array}{l}\text { Pectin lyase-like superfamily protein | chr5:19825137-19829092 } \\
\text { FORWARD LENGTH =1540 }\end{array}$ & 0.93 & 1.18 \\
\hline AT4G33070 & $\begin{array}{l}\text { Thiamine pyrophosphate dependent pyruvate decarboxylase family } \\
\text { protein | chr4:15952289-15954771 REVERSE LENGTH=2149 }\end{array}$ & 0.93 & 0.59 \\
\hline
\end{tabular}




\begin{tabular}{|c|c|c|c|}
\hline Identifier & Description & $\begin{array}{l}\text { ColLL-tgaLL } \\
\text { logFC }\end{array}$ & $\begin{array}{l}\text { ColLL-ROXYLL } \\
\text { IogFC }\end{array}$ \\
\hline AT5G18030 & $\begin{array}{l}\text { SAUR-like auxin-responsive protein family chr5:5968435-5968938 } \\
\text { FORWARD LENGTH }=504\end{array}$ & 0.93 & 1.53 \\
\hline AT5G67390 & 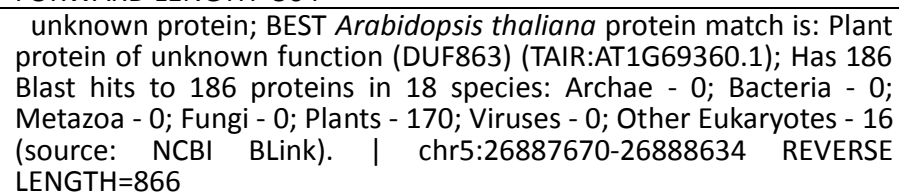 & 0.93 & 0.72 \\
\hline AT5G62170 & $\begin{array}{l}\text { unknown protein; BEST Arabidopsis thaliana protein match is: } \\
\text { unknown protein (TAIR:AT5G51850.1); Has } 381 \text { Blast hits to } 359 \\
\text { proteins in } 81 \text { species: Archae - 0; Bacteria - 16; Metazoa - 101; Fungi } \\
\text { - 21; Plants - 99; Viruses - 3; Other Eukaryotes - } 141 \text { (source: NCBI } \\
\text { BLink). | chr5:24972977-24975549 REVERSE LENGTH }=2324\end{array}$ & 0.92 & 0.98 \\
\hline AT4G29020 & $\begin{array}{c}\begin{array}{c}\text { glycine-rich protein } \\
\text { LENGTH=801 }\end{array} \\
\end{array}$ & 0.92 & 1.25 \\
\hline AT1G10820 & $\begin{array}{l}\text { Protein of unknown function (DUF3755) | chr1:3600910-3605076 } \\
\text { REVERSE LENGTH=1547 }\end{array}$ & 0.92 & 1.38 \\
\hline AT4G24275 & $\begin{array}{cccccc}\text { Identified as a screen for stress-responsive } & \text { genes. } & \text { I } \\
\text { chr4:12588519-12589062 FORWARD LENGTH=544 } & & & \\
\end{array}$ & 0.92 & 1.30 \\
\hline AT4G35070 & $\begin{array}{cccccc}\text { SBP } & \text { (S-ribonuclease } & \text { binding protein) family } & \text { protein } & \text { | } \\
\text { chr4:16694170-16695698 FORWARD LENGTH=1427 } & & \\
\end{array}$ & 0.91 & 1.19 \\
\hline AT5G61160 & \begin{tabular}{c|cccc|c} 
AACT1 I anthocyanin & 5-aromatic & acyltransferase & 1 & I \\
chr5:24608724-24610304 FORWARD LENGTH $=1581$ & & & \\
\end{tabular} & 0.91 & 0.70 \\
\hline AT1G58460 & $\begin{array}{l}\text { unknown protein; Has } 35 \text { Blast hits to } 35 \text { proteins in } 8 \text { species: } \\
\text { Archae - 0; Bacteria - 0; Metazoa - 0; Fungi - 0; Plants - 35; Viruses - } \\
\text { 0; Other Eukaryotes - } 0 \quad \text { (source: NCBI BLink). } \\
\text { chr1:21721404-21722429 FORWARD LENGTH }=534\end{array}$ & 0.91 & 0.79 \\
\hline AT3G26900 & $\begin{array}{l}\text { SKL1, ATSKL1 | shikimate kinase like } 1 \text { | chr3:9912209-9914514 } \\
\text { REVERSE LENGTH =1038 }\end{array}$ & 0.91 & 0.78 \\
\hline AT5G15265 & $\begin{array}{l}\text { unknown protein; FUNCTIONS IN: molecular_function unknown; } \\
\text { INVOLVED IN: biological_process unknown; LOCATED IN: } \\
\text { endomembrane system; Has } 5 \text { Blast hits to } 5 \text { proteins in } 3 \text { species: } \\
\text { Archae - 0; Bacteria - 0; Metazoa - } 0 \text {; Fungi - } 0 \text {; Plants - 5; Viruses - 0; } \\
\text { Other Eukaryotes - } 0 \text { (source: NCBI BLink). I chr5:4956501-4957533 } \\
\text { FORWARD LENGTH }=438\end{array}$ & 0.90 & 0.86 \\
\hline AT1G10550 & $\begin{array}{ccccc}\text { XTH33, XET | } & \text { xyloglucan:xyloglucosyl transferase } & 33 & \text { | } \\
\text { chr1:3479153-3480988 REVERSE LENGTH=1068 }\end{array}$ & 0.89 & 1.15 \\
\hline AT3G03820 & $\begin{array}{l}\text { SAUR-like auxin-responsive protein family chr3:976933-977223 } \\
\text { REVERSE LENGTH=291 }\end{array}$ & 0.89 & 1.00 \\
\hline AT1G62770 & $\begin{array}{l}\text { Plant invertase/pectin methylesterase inhibitor superfamily protein } \\
\text { | chr1:23245886-23246890 REVERSE LENGTH=868 }\end{array}$ & 0.89 & 0.68 \\
\hline AT1G01120 & $\begin{array}{l}\text { KCS1 | 3-ketoacyl-CoA synthase } 1 \text { | chr1:57269-59167 REVERSE } \\
\text { LENGTH=1899 }\end{array}$ & 0.89 & 1.04 \\
\hline AT5G22580 & $\begin{array}{l}\text { Stress responsive A/B Barrel Domain | chr5:7502674-7503449 } \\
\text { FORWARD LENGTH=683 }\end{array}$ & 0.89 & 1.00 \\
\hline AT2G48020 & $\begin{array}{l}\text { Major facilitator superfamily protein | chr2:19644100-19647178 } \\
\text { FORWARD LENGTH=1765 }\end{array}$ & 0.89 & 1.03 \\
\hline AT5G12940 & $\begin{array}{l}\text { Leucine-rich repeat (LRR) family protein | chr5:4087712-4089004 } \\
\text { FORWARD LENGTH=1293 }\end{array}$ & 0.88 & 1.15 \\
\hline AT5G07030 & $\begin{array}{cccc}\text { Eukaryotic aspartyl protease } & \text { family } & \text { protein } & \text { | } \\
\text { chr5:2183360-2185972 REVERSE LENGTH=1863 } & & \\
\end{array}$ & 0.88 & 1.15 \\
\hline AT4G38825 & $\begin{array}{l}\text { SAUR-like auxin-responsive protein family chr4:18121526-18122010 } \\
\text { FORWARD LENGTH=485 }\end{array}$ & 0.88 & 1.07 \\
\hline AT3G01472 & $\begin{array}{l}\text { CPuORF33 | conserved peptide upstream open reading frame } 33 \text { | } \\
\text { chr3:182396-184403 REVERSE LENGTH=1440 }\end{array}$ & 0.87 & 0.68 \\
\hline AT5G48560 & $\begin{array}{l}\text { basic helix-loop-helix (bHLH) DNA-binding superfamily protein I } \\
\text { chr5:19684006-19687151 FORWARD LENGTH=1931 }\end{array}$ & 0.87 & 1.05 \\
\hline AT5G22940 & $\begin{array}{ccccc}\text { F8H I FRA8 homolog } & \text { | chr5:7676938-7679179 } & \text { FORWARD } \\
\text { LENGTH=1956 } & & & \\
\end{array}$ & 0.87 & 0.87 \\
\hline AT2G43150 & $\begin{array}{l}\text { Proline-rich extensin-like family protein | chr2:17945893-17947022 } \\
\text { FORWARD LENGTH=1047 }\end{array}$ & 0.87 & 0.85 \\
\hline AT5G56030 & $\begin{array}{l}\text { HSP81-2 | heat shock protein 81-2 | chr5:22686832-22689471 } \\
\text { FORWARD LENGTH=2316 }\end{array}$ & 0.87 & 0.83 \\
\hline AT5G64552 & $\begin{array}{l}\text { CPuORF22 | conserved peptide upstream open reading frame } 22 \text { | } \\
\text { chr5:25801528-25804980 REVERSE LENGTH }=2533\end{array}$ & 0.87 & 0.85 \\
\hline AT4G00050 & $\begin{array}{l}\text { UNE10 | basic helix-loop-helix (bHLH) DNA-binding superfamily } \\
\text { protein | chr4:17792-20066 FORWARD LENGTH=1489 }\end{array}$ & 0.86 & 0.94 \\
\hline AT1G64640 & \begin{tabular}{c|cccc|} 
ENODL8, AtENODL8 & early nodulin-like & protein & 8 & I \\
chr1:24022285-24023196 REVERSE LENGTH=818 & & &
\end{tabular} & 0.86 & 1.33 \\
\hline AT2G41820 & $\begin{array}{c}\text { Leucine-rich repeat protein kinase family protein } \\
\text { chr2:17446744-17450071 FORWARD LENGTH=3256 }\end{array}$ & 0.85 & 1.06 \\
\hline
\end{tabular}




\begin{tabular}{|c|c|c|c|}
\hline Identifier & Description & $\begin{array}{l}\text { ColLL-tgaLL } \\
\text { logFC }\end{array}$ & $\begin{array}{l}\text { ColLL-ROXYLL } \\
\text { IOgFC }\end{array}$ \\
\hline AT5G07790 & $\begin{array}{l}\text { unknown protein; BEST Arabidopsis thaliana protein match is: } \\
\text { unknown protein (TAIR:AT5G61300.1); Has } 1807 \text { Blast hits to } 1807 \\
\text { proteins in } 277 \text { species: Archae - 0; Bacteria - 0; Metazoa - 736; Fungi } \\
\text { - 347; Plants - 385; Viruses - 0; Other Eukaryotes - } 339 \text { (source: NCBI } \\
\text { BLink). | chr5:2483311-2486361 FORWARD LENGTH }=2453\end{array}$ & 0.85 & 0.92 \\
\hline AT3G59900 & $\begin{array}{l}\text { ARGOS | auxin-regulated gene involved in organ size | } \\
\text { chr3:22129726-22130464 FORWARD LENGTH=739 }\end{array}$ & 0.85 & 1.39 \\
\hline AT3G04290 & $\begin{array}{l}\text { ATLTL1, LTL1 | Li-tolerant lipase } 1 \text { | chr3:1133320-1136316 REVERSE } \\
\text { LENGTH=1494 }\end{array}$ & 0.84 & 1.30 \\
\hline AT4G21760 & $\begin{array}{c}\text { BGLU47 | beta-glucosidase } 47 \quad \mid \text { chr4:11561229-11563950 } \\
\text { FORWARD LENGTH=1687 }\end{array}$ & 0.84 & 1.10 \\
\hline AT5G65390 & $\begin{array}{l}\text { AGP7 | arabinogalactan protein } 7 \text { | chr5:26128584-26129338 } \\
\text { REVERSE LENGTH=755 }\end{array}$ & 0.84 & 1.30 \\
\hline AT4G00820 & \begin{tabular}{c|cc|cc} 
iqd17 & IQ-domain & 17 & chr4:349116-351550 & FORWARD \\
LENGTH=2032 & & & & \\
\end{tabular} & 0.83 & 0.97 \\
\hline AT5G59010 & $\begin{array}{l}\text { Protein kinase protein with tetratricopeptide repeat domain I } \\
\text { chr5:23820368-23823265 REVERSE LENGTH=1936 }\end{array}$ & 0.83 & 0.92 \\
\hline AT1G18400 & \begin{tabular}{c|cc|c} 
BEE1 | BR enhanced expression 1 & | chr1:6331398-6333743 \\
FORWARD LENGTH=1016 & & & \\
\end{tabular} & 0.83 & 1.31 \\
\hline AT1G57590 & $\begin{array}{l}\text { Pectinacetylesterase family protein | chr1:21327360-21329763 } \\
\text { REVERSE LENGTH }=1489\end{array}$ & 0.82 & 0.63 \\
\hline AT4G36110 & $\begin{array}{l}\text { SAUR-like auxin-responsive protein family chr4:17089949-17090825 } \\
\text { FORWARD LENGTH=877 }\end{array}$ & 0.82 & 0.96 \\
\hline AT3G54400 & $\begin{array}{ccccc}\begin{array}{c}\text { Eukaryotic aspartyl } \\
\text { chr3:20140058-20142642 REVERSE LENGTH=1554 }\end{array} & \text { protein } & \text { I } \\
\end{array}$ & 0.81 & 1.17 \\
\hline AT1G53180 & $\begin{array}{l}\text { unknown protein; FUNCTIONS IN: molecular_function unknown; } \\
\text { INVOLVED IN: biological_process unknown; LOCATED IN: } \\
\text { cellular_component unknown; EXPRESSED IN: } 13 \text { plant structures; } \\
\text { EXPRESSED DURING: } 6 \text { growth stages; BEST Arabidopsis thaliana } \\
\text { protein match is: unknown protein (TAIR:AT3G15115.1); Has } 58 \text { Blast } \\
\text { hits to } 56 \text { proteins in } 22 \text { species: Archae - 0; Bacteria - 0; Metazoa - 6; } \\
\text { Fungi - 4; Plants - 29; Viruses - 0; Other Eukaryotes - 19 (source: NCB I } \\
\text { BLink). I chr1:19831441-19832895 FORWARD LENGTH=1386 }\end{array}$ & 0.81 & 0.99 \\
\hline AT2G39920 & $\begin{array}{cccc}\text { HAD superfamily, subfamily IIIB acid phosphatase } \\
\text { chr2:16663017-16664539 }\end{array}$ & 0.81 & 0.89 \\
\hline AT4G13920 & $\begin{array}{l}\text { AtRLP50, RLP50 | receptor like protein } 50 \mid \text { chr4:8043803-8046559 } \\
\text { FORWARD LENGTH=2757 }\end{array}$ & 0.81 & 0.66 \\
\hline AT3G15536 & Unknown gene | chr3:5260723-5261322 FORWARD LENGTH=495 & 0.80 & 0.82 \\
\hline AT1G53070 & $\begin{array}{l}\text { Legume lectin family protein | chr1:19778333-19779373 FORWARD } \\
\text { LENGTH=1041 }\end{array}$ & 0.80 & 0.91 \\
\hline AT1G28130 & \begin{tabular}{c|cccc} 
GH3.17 | & Auxin-responsive $\quad$ GH3 family & protein & | \\
chr1:9825286-9828067 FORWARD LENGTH $=2159$ & &
\end{tabular} & 0.79 & 0.94 \\
\hline AT2G42380 & $\begin{array}{l}\text { ATBZIP34, BZIP34 | Basic-leucine zipper (bZIP) transcription factor } \\
\text { family protein | chr2:17646900-17648945 REVERSE LENGTH=1556 }\end{array}$ & 0.79 & 1.22 \\
\hline AT5G06440 & $\begin{array}{l}\text { BEST Arabidopsis thaliana protein match is: Polyketide } \\
\text { cyclase/dehydrase and lipid transport superfamily protein } \\
\text { (TAIR:AT3G11720.3); Has } 157 \text { Blast hits to } 155 \text { proteins in 41 species: } \\
\text { Archae - 0; Bacteria - 6; Metazoa - 5; Fungi - 6; Plants - 99; Viruses - } \\
\text { 0; Other Eukaryotes - 41 (source: NCBI BLink). } \\
\text { chr5:1964468-1966955 REVERSE LENGTH=1761 }\end{array}$ & 0.78 & 0.83 \\
\hline AT2G29130 & $\begin{array}{l}\text { LAC2, ATLAC2 | laccase } 2 \text { | chr2:12524889-12527747 REVERSE } \\
\text { LENGTH=2070 }\end{array}$ & 0.77 & 1.04 \\
\hline AT3G43190 & $\begin{array}{l}\text { SUS4, ATSUS4 | sucrose synthase } 4 \text { | chr3:15179020-15183989 } \\
\text { REVERSE LENGTH=2764 }\end{array}$ & 0.77 & 1.01 \\
\hline AT4G21650 & $\begin{array}{l}\begin{array}{l}\text { Subtilase family protein | chr4:11501198-11504678 } \\
\text { LENGTH=2439 }\end{array} \\
\text { REVERSE }\end{array}$ & 0.77 & 0.86 \\
\hline AT1G15550 & $\begin{array}{cccccc}\text { GA4, ATGA3OX1, } & \text { GA3OX1 } & \text { I gibberellin } & \text { 3-oxidase } & 1 & \text { I } \\
\text { chr1:5344478-5346166 REVERSE LENGTH=1256 } & & & & \end{array}$ & 0.77 & 1.13 \\
\hline AT5G03120 & $\begin{array}{l}\text { unknown protein; FUNCTIONS IN: molecular_function unknown; } \\
\text { INVOLVED IN: biological_process unknown; LOCATED IN: } \\
\text { endomembrane system; EXPRESSED IN: } 21 \text { plant structures; } \\
\text { EXPRESSED DURING: } 13 \text { growth stages; Has } 14 \text { Blast hits to 14 } \\
\text { proteins in } 4 \text { species: Archae - 0; Bacteria - 0; Metazoa - 0; Fungi - 0; } \\
\text { Plants - 14; Viruses - 0; Other Eukaryotes - } 0 \text { (source: NCBI BLink). I } \\
\text { chr5:733979-734943 FORWARD LENGTH }=574\end{array}$ & 0.76 & 0.84 \\
\hline AT3G16360 & $\begin{array}{l}\text { AHP4 I HPT phosphotransmitter } 4 \text { | chr3:5554474-5555393 } \\
\text { FORWARD LENGTH=420 }\end{array}$ & 0.76 & 0.94 \\
\hline AT1G68600 & $\begin{array}{c}\text { Aluminium activated malate transporter family protein } \\
\text { chr1:25759842-25762934 FORWARD LENGTH=1875 }\end{array}$ & 0.75 & 0.91 \\
\hline AT1G10970 & $\begin{array}{l}\text { ZIP4, ATZIP4 | zinc transporter } 4 \text { precursor | chr1:3665087-3667139 } \\
\text { REVERSE LENGTH=1547 }\end{array}$ & 0.75 & 0.60 \\
\hline AT3G12500 & $\begin{array}{l}\text { ATHCHIB, PR3, PR-3, CHI-B, B-CHI, HCHIB | basic chitinase | } \\
\text { chr3:3962382-3963984 REVERSE LENGTH=1127 }\end{array}$ & 0.74 & 0.98 \\
\hline
\end{tabular}




\begin{tabular}{|c|c|c|c|}
\hline Identifier & \multicolumn{1}{|c|}{ Description } & $\begin{array}{c}\text { ColLL-tgaLL } \\
\text { logFC }\end{array}$ & $\begin{array}{c}\text { ColLL-ROXYLL } \\
\text { logFC }\end{array}$ \\
\hline AT5G04160 & $\begin{array}{l}\text { Nucleotide-sugar transporter family protein I } \\
\text { chr5:1142782-1144912 REVERSE LENGTH=1316 }\end{array}$ & 0.74 & 0.92 \\
\hline AT3G62090 & $\begin{array}{c}\text { PIL2 I phytochrome interacting factor 3-like 2 I } \\
\text { chr3:22988547-22990709 REVERSE LENGTH=1614 }\end{array}$ & 0.74 & 1.20 \\
\hline AT3G18210 & $\begin{array}{l}\text { 2-oxoglutarate (20G) and Fe(II)-dependent oxygenase superfamily } \\
\text { protein | chr3:6237930-6240605 REVERSE LENGTH=1728 }\end{array}$ & 0.71 & 1.00 \\
\hline
\end{tabular}

Table S2 List of 167 genes of cluster 5.

\begin{tabular}{|c|c|c|c|c|}
\hline Identifier & Description & $\begin{array}{l}\text { Col-ColLL } \\
\operatorname{logFC}\end{array}$ & $\begin{array}{l}\text { ColLL-tgaLL } \\
\operatorname{logFC}\end{array}$ & $\begin{array}{l}\text { CoILL-ROXYLL } \\
\quad \operatorname{logFC}\end{array}$ \\
\hline AT4G31430 & $\begin{array}{l}\text { unknown protein; LOCATED IN: plasma membrane; } \\
\text { EXPRESSED IN: } 25 \text { plant structures; EXPRESSED } \\
\text { DURING: } 15 \text { growth stages; Has } 35333 \text { Blast hits to } \\
34131 \text { proteins in } 2444 \text { species: Archae - 798; Bacteria - } \\
\text { 22429; Metazoa - } 974 \text {; Fungi - } 991 \text {; Plants - 531; Viruses } \\
\text { - 0; Other Eukaryotes - } 9610 \text { (source: NCBI BLink). I } \\
\text { chr4:15248456-15252529 FORWARD LENGTH=2104 }\end{array}$ & -2.29 & 0.65 & 1.84 \\
\hline AT1G19530 & $\begin{array}{l}\text { unknown protein; FUNCTIONS IN: molecular_function } \\
\text { unknown; INVOLVED IN: N-terminal protein } \\
\text { myristoylation, anaerobic respiration; LOCATED IN: } \\
\text { cellular_component unknown; EXPRESSED IN: leaf } \\
\text { apex, inflorescence meristem, hypocotyl, root, flower; } \\
\text { EXPRESSED DURING: petal differentiation and } \\
\text { expansion stage; Has } 47 \text { Blast hits to } 47 \text { proteins in } 13 \\
\text { species: Archae - 0; Bacteria - 0; Metazoa - 0; Fungi - 0; } \\
\text { Plants - 47; Viruses - 0; Other Eukaryotes - O (source: } \\
\text { NCBI BLink). I chr1:6763915-6764971 FORWARD } \\
\text { LENGTH=700 }\end{array}$ & -2.21 & 1.04 & 1.56 \\
\hline AT1G75920 & $\begin{array}{l}\text { GDSL-like Lipase/Acylhydrolase superfamily protein | } \\
\text { chr1:28505554-28507168 FORWARD LENGTH=1106 }\end{array}$ & -2.04 & 1.68 & 2.28 \\
\hline AT4G08040 & $\begin{array}{l}\text { ACS11 | 1-aminocyclopropane-1-carboxylate synthase } \\
11 \mid \text { chr4:4887112-4888939 FORWARD LENGTH=1383 }\end{array}$ & -1.54 & 1.14 & 0.99 \\
\hline AT2G18480 & $\begin{array}{ccc}\text { Major facilitator superfamily } & \text { protein } \\
\text { chr2:8009323-8011255 } & \text { REVERSE LENGTH=1798 }\end{array}$ & -1.53 & 0.61 & 1.38 \\
\hline AT4G04570 & 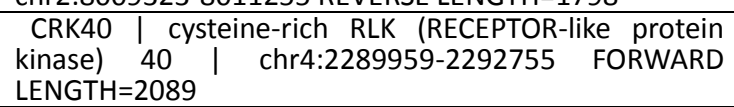 & -1.53 & 0.37 & 1.84 \\
\hline AT5G10430 & \begin{tabular}{cc|ccc} 
AGP4, ATAGP4 I arabinogalactan protein & 4 & I \\
chr5:3277532-3278313 REVERSE LENGTH $=782$ & &
\end{tabular} & -1.52 & 1.11 & 1.85 \\
\hline AT2G21540 & $\begin{array}{l}\text { ATSFH3, SFH3 | SEC14-like 3 | chr2:9220556-9224496 } \\
\text { REVERSE LENGTH=2106 }\end{array}$ & -1.52 & 1.43 & 1.57 \\
\hline AT4G01680 & $\begin{array}{c}\text { MYB55 I myb domain protein } \\
\text { chr4:716021-717415 REVERSE LENGTH=1248 }\end{array}$ & -1.51 & 1.31 & 1.21 \\
\hline AT5G22940 & $\begin{array}{c}\text { F8H | FRA8 homolog | chr5:7676938-7679179 } \\
\text { FORWARD LENGTH=1956 }\end{array}$ & -1.47 & 0.87 & 0.87 \\
\hline AT5G22820 & $\begin{array}{cccc}\text { ARM } & \text { repeat } & \text { superfamily } & \text { protein } \\
\text { chr5:7623440-7626975 } & \text { REVERSE LENGTH }=1997\end{array}$ & -1.47 & 1.46 & 1.59 \\
\hline AT1G67265 & $\begin{array}{c}\text { DVL3, RTFL21 | ROTUNDIFOLIA like } 21 \\
\text { chr1:25175558-25176202 REVERSE LENGTH=645 }\end{array}$ & -1.43 & 0.42 & 1.17 \\
\hline AT2G46320 & $\begin{array}{c}\text { Mitochondrial substrate carrier family protein } \\
\text { chr2:19015813-19018230 FORWARD LENGTH=1497 }\end{array}$ & -1.40 & 1.05 & 1.31 \\
\hline AT5G25760 & $\begin{array}{l}\text { PEX4, UBC21 | peroxin4 | chr5:8967655-8969349 } \\
\text { FORWARD LENGTH=745 }\end{array}$ & -1.39 & 2.06 & 1.78 \\
\hline AT1G10820 & $\begin{array}{c}\text { Protein of unknown function } \\
\text { chr1:3600910-3605076 REVERSE LENGTH=1547 }\end{array}$ & -1.38 & 0.92 & 1.38 \\
\hline AT2G14900 & $\begin{array}{c}\text { Gibberellin-regulated family } \\
\text { chr2:6404175-6405330 FORWARD LENGTH=649 }\end{array}$ & -1.33 & 0.69 & 1.04 \\
\hline AT1G10550 & $\begin{array}{l}\text { XTH33, XET | xyloglucan:xyloglucosyl transferase } 33 \text { | } \\
\text { chr1:3479153-3480988 REVERSE LENGTH=1068 }\end{array}$ & -1.33 & 0.89 & 1.15 \\
\hline AT3G07610 & $\begin{array}{l}\text { IBM1 | Transcription factor jumonji (jmjC) } \\
\text { domain-containing protein | chr3:2426148-2432876 } \\
\text { FORWARD LENGTH=3084 }\end{array}$ & -1.32 & 1.75 & 0.85 \\
\hline AT5G66600 & $\begin{array}{c}\text { Protein of unknown function, } \text { DUF547 } \\
\text { chr5:26575000-26578826 REVERSE LENGTH=2461 }\end{array}$ & -1.31 & 1.71 & 1.33 \\
\hline AT5G17920 & $\begin{array}{l}\text { ATCIMS, ATMETS, ATMS1 } \\
\text { synthase family protein } \\
\text { FORWARD LENGTH=2771 }\end{array}$ & -1.26 & 1.61 & 1.25 \\
\hline AT1G74670 & $\begin{array}{c}\text { Gibberellin-regulated } \quad \text { family } \\
\text { chr1:28053286-28054149 FORWARD LENGTH }=654\end{array}$ & -1.25 & 0.63 & 1.29 \\
\hline
\end{tabular}




\begin{tabular}{|c|c|c|c|c|}
\hline Identifier & Description & $\begin{array}{c}\text { Col-ColLL } \\
\text { logFC }\end{array}$ & $\begin{array}{l}\text { ColLL-tgaLL } \\
\text { logFC }\end{array}$ & $\begin{array}{c}\text { ColLL-ROXYLL } \\
\text { logFC }\end{array}$ \\
\hline AT1G11120 & $\begin{array}{l}\text { unknown protein; FUNCTIONS IN: molecular_function } \\
\text { unknown; INVOLVED IN: biological_process unknown; } \\
\text { LOCATED IN: cellular_component unknown; EXPRESSED } \\
\text { IN: } 10 \text { plant structures; EXPRESSED DURING: } 4 \text { anthesis, } \\
\text { F mature embryo stage, petal differentiation and } \\
\text { expansion stage, E expanded cotyledon stage, D } \\
\text { bilateral stage; BEST Arabidopsis thaliana protein match } \\
\text { is: unknown protein (TAIR:AT4G28170.1); Has } 94 \text { Blast } \\
\text { hits to } 94 \text { proteins in } 13 \text { species: Archae - 0; Bacteria - } \\
\text { 0; Metazoa - 0; Fungi - 0; Plants - 94; Viruses - 0; Other } \\
\text { Eukaryotes - } 0 \text { (source: NCBI BLink). } \\
\text { chr1:3715184-3717320 FORWARD LENGTH }=531\end{array}$ & -1.20 & 0.99 & 1.36 \\
\hline AT5G19210 & $\begin{array}{l}\text { P-loop containing nucleoside triphosphate hydrolases } \\
\text { superfamily protein | chr5:6461391-6463866 } \\
\text { FORWARD LENGTH=1647 }\end{array}$ & -1.18 & 0.64 & 2.23 \\
\hline AT4G30180 & 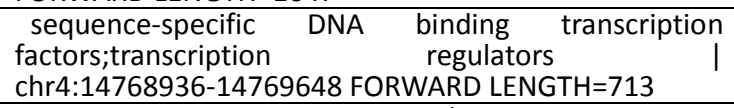 & -1.17 & 0.95 & 1.04 \\
\hline AT4G14130 & $\begin{array}{l}\text { XTR7, XTH15 } \\
\text { endotransglucosylase/hydrolase } \\
\text { chr4:8137051-8138281 REVERSE LENGTH }=1065\end{array}$ & $\begin{array}{l}-1.14 \\
\end{array}$ & 0.95 & 0.72 \\
\hline AT2G23760 & $\begin{array}{c}\text { BLH4, } \\
\text { chr2:10107709-10113213 REVERSE LENGTH=2386 }\end{array}$ & -1.13 & 0.28 & 1.81 \\
\hline AT4G32280 & $\begin{array}{l}\text { IAA29 I indole-3-acetic acid inducible } 29 \\
\text { chr4:15583387-15584769 FORWARD LENGTH=989 }\end{array}$ & -1.13 & 0.60 & 1.44 \\
\hline AT3G53350 & \begin{tabular}{c|cccc} 
RIP4 & ROP & interactive & partner & 4 \\
chr3:19780091-19782680 REVERSE LENGTH=1496
\end{tabular} & -1.13 & 0.41 & 1.20 \\
\hline AT2G37550 & \begin{tabular}{cc|cc} 
ASP1, & AGD7 & ARF-GAP & domain \\
chr2:15755097-15757601 REVERSE LENGTH=1882
\end{tabular} & -1.11 & 0.84 & 1.13 \\
\hline AT4G16260 & $\begin{array}{cccc}\text { Glycosyl } & \text { hydrolase } & \text { superfamily } & \text { protein } \\
\text { chr4:9200010-9201552 REVERSE LENGTH }=1316\end{array}$ & -1.11 & 0.98 & 0.98 \\
\hline AT4G10160 & $\begin{array}{ccc}\text { RING/U-box } & \text { superfamily } & \text { protein } \\
\text { chr4:6336023-6337332 FORWARD LENGTH=709 }\end{array}$ & -1.10 & 0.58 & 1.04 \\
\hline AT5G15265 & $\begin{array}{l}\text { unknown protein; FUNCTIONS IN: molecular_function } \\
\text { unknown; INVOLVED IN: biological_process unknown; } \\
\text { LOCATED IN: endomembrane system; Has } 5 \text { Blast hits to } \\
5 \text { proteins in } 3 \text { species: Archae - 0; Bacteria - 0; Metazoa } \\
\text { - 0; Fungi - 0; Plants - 5; Viruses - 0; Other Eukaryotes - } \\
0 \quad \text { (source: NCBI BLink). I chr5:4956501-4957533 } \\
\text { FORWARD LENGTH=438 }\end{array}$ & -1.09 & 0.90 & 0.86 \\
\hline AT5G59780 & $\begin{array}{l}\text { MYB59, ATMYB59, ATMYB59-1 | myb domain protein } \\
59 \mid \text { chr5:24082197-24083431 REVERSE LENGTH=1128 }\end{array}$ & -1.09 & 0.53 & 0.92 \\
\hline AT3G29370 & $\begin{array}{l}\text { unknown protein; BEST Arabidopsis thaliana protein } \\
\text { match is: unknown protein (TAIR:AT5G39240.1); Has } 16 \\
\text { Blast hits to } 16 \text { proteins in } 5 \text { species: Archae - 0; } \\
\text { Bacteria - 0; Metazoa - 0; Fungi - 0; Plants - 16; Viruses - } \\
\text { 0; Other Eukaryotes - } 0 \text { (source: NCBI BLink). I } \\
\text { chr3:11278589-11279108 FORWARD LENGTH }=520\end{array}$ & -1.09 & 0.29 & 1.01 \\
\hline AT5G57150 & \begin{tabular}{l}
\multicolumn{3}{l}{ basic helix-loop-helix (bHLH) DNA-binding superfamily } \\
protein | chr5:23152186-23154264 \\
LENGTH=1827
\end{tabular} & -1.07 & 0.99 & 0.70 \\
\hline AT2G44500 & $\begin{array}{ccc}\text { O-fucosyltransferase } & \text { family } & \text { protein } \\
\text { chr2:18374292-18376790 FORWARD LENGTH }=2311\end{array}$ & -1.06 & 0.94 & 0.76 \\
\hline AT2G22122 & $\begin{array}{l}\text { unknown protein; Has } 35333 \text { Blast hits to } 34131 \\
\text { proteins in 2444 species: Archae - 798; Bacteria - } \\
\text { 22429; Metazoa - 974; Fungi - 991; Plants - 531; Viruses } \\
\text { - 0; Other Eukaryotes - } 9610 \text { (source: NCBI BLink). I } \\
\text { chr2:9403264-9403808 FORWARD LENGTH }=545\end{array}$ & -1.06 & 0.58 & 1.09 \\
\hline AT1G26208 & \begin{tabular}{cc|cc} 
other & RNA & I chr1:9066636-9068432 & REVERSE \\
LENGTH=1499 & &
\end{tabular} & -1.06 & 0.66 & 0.63 \\
\hline AT3G61880 & \begin{tabular}{c|crr} 
CYP78A9 I cytochrome p450 & 78a9 \\
chr3:22905868-22907958 REVERSE LENGTH $=1919$
\end{tabular} & -1.03 & 1.42 & 2.15 \\
\hline AT4G06701 & \begin{tabular}{cc|cc} 
other & RNA \\
LENGTH=511
\end{tabular} & -1.03 & 0.49 & 1.13 \\
\hline AT3G58620 & $\begin{array}{c}\text { TTL4 | tetratricopetide-repeat thioredoxin-like } 4 \text { | } \\
\text { chr3:21680326-21683135 FORWARD LENGTH=2296 }\end{array}$ & -1.03 & 0.39 & 0.86 \\
\hline AT3G58120 & 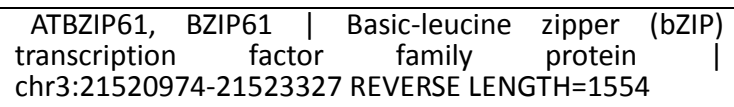 & -1.03 & 0.63 & 0.85 \\
\hline
\end{tabular}




\begin{tabular}{|c|c|c|c|c|}
\hline Identifier & Description & $\begin{array}{c}\text { Col-ColLL } \\
\text { logFC }\end{array}$ & $\begin{array}{c}\text { ColLL-tgaLL } \\
\text { logFC }\end{array}$ & $\begin{array}{c}\text { ColLL-ROXYLL } \\
\text { logFC }\end{array}$ \\
\hline AT5G03120 & $\begin{array}{l}\text { unknown protein; FUNCTIONS IN: molecular_function } \\
\text { unknown; INVOLVED IN: biological_process unknown; } \\
\text { LOCATED IN: endomembrane system; EXPRESSED IN: } 21 \\
\text { plant structures; EXPRESSED DURING: } 13 \text { growth stages; } \\
\text { Has } 14 \text { Blast hits to } 14 \text { proteins in } 4 \text { species: Archae - 0; } \\
\text { Bacteria - 0; Metazoa - 0; Fungi - 0; Plants - } 14 \text {; Viruses - } \\
\text { 0; Other Eukaryotes - } 0 \text { (source: NCBI BLink). I } \\
\text { chr5:733979-734943 FORWARD LENGTH }=574\end{array}$ & -1.02 & 0.76 & 0.84 \\
\hline AT3G23050 & $\begin{array}{cccc}\text { IAA7, AXR2 I indole-3-acetic acid } & 7 & \text { | } \\
\text { chr3:8194711-8196514 FORWARD LENGTH=990 } & \end{array}$ & -1.02 & 0.51 & 0.68 \\
\hline AT4G20910 & $\begin{array}{l}\text { HEN1, CRM2 I double-stranded RNA binding } \\
\text { protein-related / DsRBD protein-related } \\
\text { chr4:11186084-11190691 REVERSE LENGTH=3125 }\end{array}$ & -0.99 & 1.60 & 0.83 \\
\hline AT5G02760 & $\begin{array}{c}\text { Protein phosphatase } 2 \mathrm{C} \text { family protein } \\
\text { chr5:625254-627124 FORWARD LENGTH }=1543\end{array}$ & -0.97 & 0.40 & 1.57 \\
\hline AT5G50335 & $\begin{array}{l}\text { unknown protein; Has } 30201 \text { Blast hits to } 17322 \\
\text { proteins in } 780 \text { species: Archae - 12; Bacteria - 1396; } \\
\text { Metazoa - } 17338 \text {; Fungi - } 3422 \text {; Plants - 5037; Viruses - } \\
\text { 0; Other Eukaryotes - 2996 (source: NCBI BLink). I } \\
\text { chr5:20489094-20489727 REVERSE LENGTH=634 }\end{array}$ & -0.96 & 0.96 & 0.90 \\
\hline AT5G19810 & $\begin{array}{c}\text { Proline-rich extensin-like family protein } \\
\text { chr5:6693052-6693801 FORWARD LENGTH=750 }\end{array}$ & -0.95 & 0.62 & 0.92 \\
\hline AT1G51690 & $\begin{array}{l}\text { ATB ALPHA, B ALPHA | protein phosphatase } 2 \mathrm{~A} 55 \mathrm{kDa} \\
\text { regulatory subunit B alpha isoform I } \\
\text { chr1:19164063-19170446 FORWARD LENGTH=3741 }\end{array}$ & -0.95 & 0.44 & 1.37 \\
\hline AT5G59010 & $\begin{array}{lll}\begin{array}{l}\text { Protein kinase protein with tetratricopeptide repeat } \\
\text { domain } \mid\end{array} & \text { chr5:23820368-23823265 } & \text { REVERSE } \\
\text { LENGTH=1936 } & & \end{array}$ & -0.93 & 0.83 & 0.92 \\
\hline AT5G24570 & $\begin{array}{l}\text { unknown protein; Has } 30201 \text { Blast hits to } 17322 \\
\text { proteins in } 780 \text { species: Archae - 12; Bacteria - 1396; } \\
\text { Metazoa - } 17338 \text {; Fungi - 3422; Plants - 5037; Viruses - } \\
\text { 0; Other Eukaryotes - 2996 (source: NCBI BLink). I } \\
\text { chr5:8405681-8406132 REVERSE LENGTH=452 }\end{array}$ & -0.93 & 0.46 & 0.87 \\
\hline AT2G48020 & $\begin{array}{cccc}\text { Major facilitator } & \text { superfamily } & \text { protein } \\
\text { chr2:19644100-19647178 } & \text { FORWARD LENGTH=1765 }\end{array}$ & -0.92 & 0.89 & 1.03 \\
\hline AT1G09270 & $\begin{array}{c}\text { IMPA-4 I importin alpha isoform } 4 \\
\text { chr1:2994369-2998222 FORWARD LENGTH=2062 }\end{array}$ & -0.92 & 0.71 & 1.38 \\
\hline AT4G23450 & $\begin{array}{l}\text { AIRP1, AtAIRP1 | RING/U-box superfamily protein | } \\
\text { chr4:12240803-12242706 REVERSE LENGTH=1031 }\end{array}$ & -0.91 & 1.76 & 0.76 \\
\hline AT5G65430 & $\begin{array}{c}\text { GRF8, GF14 KAPPA I general regulatory factor } 8 \text { | } \\
\text { chr5:26148201-26150342 REVERSE LENGTH }=1173\end{array}$ & -0.90 & 0.85 & 1.26 \\
\hline AT4G24275 & $\begin{array}{l}\text { Identified as a screen for stress-responsive genes. I } \\
\text { chr4:12588519-12589062 FORWARD LENGTH=544 }\end{array}$ & -0.90 & 0.92 & 1.30 \\
\hline AT1G47820 & $\begin{array}{l}\text { unknown protein; BEST Arabidopsis thaliana protein } \\
\text { match is: unknown protein (TAIR:AT1G47813.1); Has } 29 \\
\text { Blast hits to } 29 \text { proteins in } 9 \text { species: Archae - 0; } \\
\text { Bacteria - 0; Metazoa - 0; Fungi - 0; Plants - 29; Viruses - } \\
\text { 0; Other Eukaryotes - 0 (source: NCBI BLink). I } \\
\text { chr1:17612038-17612548 FORWARD LENGTH=511 }\end{array}$ & -0.90 & 0.26 & 1.28 \\
\hline AT3G23030 & $\begin{array}{cccc}\text { IAA2 I indole-3-acetic acid inducible } & 2 \\
\text { chr3:8180768-8181800 REVERSE LENGTH=941 }\end{array}$ & -0.87 & 1.00 & 1.32 \\
\hline AT5G65390 & \begin{tabular}{c|cc|} 
AGP7 & arabinogalactan protein & 7 \\
chr5:26128584-26129338 REVERSE LENGTH $=755$
\end{tabular} & -0.87 & 0.84 & 1.30 \\
\hline AT1G15550 & $\begin{array}{l}\text { GA4, ATGA3OX1, GA3OX1 | gibberellin 3-oxidase 1 | } \\
\text { chr1:5344478-5346166 REVERSE LENGTH=1256 }\end{array}$ & -0.87 & 0.77 & 1.13 \\
\hline AT3G12500 & $\begin{array}{l}\text { ATHCHIB, PR3, PR-3, CHI-B, B-CHI, HCHIB I basic } \\
\text { chitinase | | chr3:3962382-3963984 } \\
\text { LENGTH=1127 }\end{array}$ & -0.87 & 0.74 & 0.98 \\
\hline AT3G02410 & $\begin{array}{c}\text { ICME-LIKE2 I } \text { alpha/beta-Hydrolases } \\
\text { protein | chr3:492118-494948 REVERSE LENGTH=1335 }\end{array}$ & -0.86 & 0.45 & 1.08 \\
\hline AT4G21160 & $\begin{array}{l}\text { ZAC I Calcium-dependent ARF-type GTPase activating } \\
\text { protein family I chr4:11284238-11286767 FORWARD } \\
\text { LENGTH=1404 }\end{array}$ & -0.86 & 1.53 & 0.47 \\
\hline AT4G35070 & $\begin{array}{l}\text { SBP (S-ribonuclease binding protein) family protein | } \\
\text { chr4:16694170-16695698 FORWARD LENGTH=1427 }\end{array}$ & -0.85 & 0.91 & 1.19 \\
\hline AT5G61160 & $\begin{array}{l}\text { AACT1 | anthocyanin 5-aromatic acyltransferase 1 | } \\
\text { chr5:24608724-24610304 FORWARD LENGTH=1581 }\end{array}$ & -0.85 & 0.91 & 0.70 \\
\hline AT2G24300 & \begin{tabular}{cc|} 
Calmodulin-binding & protein \\
chr2:10340816-10343736 FORWARD LENGTH=2214
\end{tabular} & -0.84 & 1.10 & 1.02 \\
\hline AT2G15130 & $\begin{array}{l}\text { Plant basic secretory protein (BSP) family protein } \\
\text { chr2:6564945-6566004 FORWARD LENGTH }=1060\end{array}$ & -0.84 & 0.39 & 0.96 \\
\hline AT2G28085 & $\begin{array}{c}\text { SAUR-like auxin-responsive protein family } \\
\text { chr2:11968120-11968620 REVERSE LENGTH=501 }\end{array}$ & -0.84 & 0.87 & 0.41 \\
\hline
\end{tabular}




\begin{tabular}{|c|c|c|c|c|}
\hline Identifier & Description & $\begin{array}{l}\text { Col-ColLL } \\
\text { logFC }\end{array}$ & $\begin{array}{l}\text { ColLL-tgaLL } \\
\text { logFC }\end{array}$ & $\begin{array}{l}\text { CoILL-ROXYLL } \\
\text { logFC }\end{array}$ \\
\hline AT3G50970 & $\begin{array}{c}\text { LTI30, XERO2 I dehydrin family protein } \\
\text { chr3:18940777-18941554 FORWARD LENGTH=778 }\end{array}$ & -0.83 & 0.65 & 0.79 \\
\hline AT1G62770 & $\begin{array}{l}\text { Plant invertase/pectin } \\
\text { superfamily protein } \\
\text { REVERSE LENGTH=868 }\end{array}$ & -0.83 & 0.89 & 0.68 \\
\hline AT1G53180 & $\begin{array}{l}\text { unknown protein; FUNCTIONS IN: molecular_function } \\
\text { unknown; INVOLVED IN: biological_process unknown; } \\
\text { LOCATED IN: cellular_component unknown; EXPRESSED } \\
\text { IN: } 13 \text { plant structures; EXPRESSED DURING: } 6 \text { growth } \\
\text { stages; BEST Arabidopsis thaliana protein match is: } \\
\text { unknown protein (TAIR:AT3G15115.1); Has } 58 \text { Blast hits } \\
\text { to } 56 \text { proteins in } 22 \text { species: Archae - 0; Bacteria - 0; } \\
\text { Metazoa - 6; Fungi - 4; Plants - 29; Viruses - 0; Other } \\
\text { Eukaryotes - } 19 \text { (source: NCBI BLink). } \\
\text { chr1:19831441-19832895 FORWARD LENGTH=1386 }\end{array}$ & -0.83 & 0.81 & 0.99 \\
\hline AT1G52750 & $\begin{array}{c}\text { alpha/beta-Hydrolases superfamily protein } \\
\text { chr1:19646465-19649261 REVERSE LENGTH=2275 }\end{array}$ & -0.83 & 1.00 & 1.55 \\
\hline AT1G78970 & $\begin{array}{ccc}\text { LUP1, ATLUP1 I lupeol synthase } 1 & \text { I } \\
\text { chr1:29703062-29707844 FORWARD LENGTH=2642 }\end{array}$ & -0.80 & 1.15 & 1.85 \\
\hline AT1G63380 & $\begin{array}{l}\text { NAD(P)-binding Rossmann-fold superfamily protein I } \\
\text { chr1:23505557-23506391 FORWARD LENGTH=709 }\end{array}$ & -0.79 & 1.99 & 1.52 \\
\hline AT1G28130 & $\begin{array}{c}\text { GH3.17 | Auxin-responsive GH3 family protein | } \\
\text { chr1:9825286-9828067 FORWARD LENGTH }=2159\end{array}$ & -0.78 & 0.79 & 0.94 \\
\hline AT5G06930 & $\begin{array}{l}\text { LOCATED IN: chloroplast; EXPRESSED IN: } 15 \text { plant } \\
\text { structures; EXPRESSED DURING: } 7 \text { growth stages; BEST } \\
\text { Arabidopsis thaliana protein match is: nucleolar protein } \\
\text { gar2-related (TAIR:AT2G42320.2); Has } 3369 \text { Blast hits to } \\
\text { 1526 proteins in } 313 \text { species: Archae - 2; Bacteria - 910; } \\
\text { Metazoa - 754; Fungi - 336; Plants - 137; Viruses - 11; } \\
\text { Other Eukaryotes - 1219 (source: NCBI BLink). } \\
\text { chr5:2144999-2148039 FORWARD LENGTH=2502 }\end{array}$ & -0.77 & 1.06 & 1.26 \\
\hline AT4G32460 & $\begin{array}{c}\text { Protein of unknown function, DUF642 } \\
\text { chr4:15662266-15664948 REVERSE LENGTH=1257 }\end{array}$ & -0.77 & 0.96 & 1.52 \\
\hline AT3G62090 & $\begin{array}{c}\text { PIL2 | phytochrome interacting factor 3-like } 2 \text { | } \\
\text { chr3:22988547-22990709 REVERSE LENGTH=1614 }\end{array}$ & -0.77 & 0.74 & 1.20 \\
\hline AT1G26440 & $\begin{array}{ccccc}\text { ATUPS5, UPS5 I } & \text { ureide permease } & 5 & \text { | } \\
\text { chr1:9143967-9145987 REVERSE LENGTH=1698 } & & \end{array}$ & -0.76 & 0.77 & 1.38 \\
\hline AT3G54030 & $\begin{array}{ll}\begin{array}{l}\text { Protein kinase protein with tetratricopeptide repeat } \\
\text { domain }|| \text { chr3:20010927-20013693 } \\
\text { LENGTH=1911 }\end{array} & \text { FORWARD } \\
\end{array}$ & -0.76 & 0.58 & 1.23 \\
\hline AT4G03415 & $\begin{array}{ccccc}\text { Protein phosphatase } & 2 \mathrm{C} & \text { family } & \text { protein } \\
\text { chr4:1503708-1506500 REVERSE LENGTH }=1732\end{array}$ & -0.76 & 1.20 & 0.38 \\
\hline AT4G38825 & $\begin{array}{l}\text { SAUR-like auxin-responsive protein family } \\
\text { chr4:18121526-18122010 FORWARD LENGTH }=485\end{array}$ & -0.75 & 0.88 & 1.07 \\
\hline AT5G23210 & \begin{tabular}{c|cc|} 
SCPL34 I serine & carboxypeptidase-like 34 \\
chr5:7810855-7815039 FORWARD LENGTH $=1848$
\end{tabular} & -0.75 & 1.22 & 1.44 \\
\hline AT4G04745 & $\begin{array}{l}\text { unknown protein; BEST Arabidopsis thaliana protein } \\
\text { match is: unknown protein (TAIR:AT4G21902.1); Has } 32 \\
\text { Blast hits to } 32 \text { proteins in } 9 \text { species: Archae - 0; } \\
\text { Bacteria - 0; Metazoa - 0; Fungi - 0; Plants - 32; Viruses - } \\
\text { 0; Other Eukaryotes - } 0 \text { (source: NCBI BLink). I } \\
\text { chr4:2412754-2413328 REVERSE LENGTH }=575\end{array}$ & -0.73 & 0.52 & 0.94 \\
\hline AT4G11830 & \begin{tabular}{c|ccc} 
PLDGAMMA2 & phospholipase D gamma & 2 & I \\
chr4:7115736-7121245 REVERSE LENGTH $=3820$ & &
\end{tabular} & -0.72 & 0.95 & 1.41 \\
\hline AT5G12880 & $\begin{array}{l}\text { proline-rich family protein | chr5:4068519-4068962 } \\
\text { REVERSE LENGTH=444 }\end{array}$ & -0.72 & 1.25 & 0.91 \\
\hline AT1G58460 & $\begin{array}{l}\text { unknown protein; Has } 35 \text { Blast hits to } 35 \text { proteins in } 8 \\
\text { species: Archae - 0; Bacteria - 0; Metazoa - 0; Fungi - 0; } \\
\text { Plants - 35; Viruses - 0; Other Eukaryotes - O (source: } \\
\text { NCBI BLink). I chr1:21721404-21722429 FORWARD } \\
\text { LENGTH=534 }\end{array}$ & -0.70 & 0.91 & 0.79 \\
\hline AT2G10606 & $\begin{array}{l}\text { MIR396A | MIR396A; miRNA | chr2:4142323-4142473 } \\
\text { REVERSE LENGTH=151 }\end{array}$ & -0.70 & 1.03 & 1.21 \\
\hline AT2G29130 & $\begin{array}{l}\text { LAC2, ATLAC2 | laccase } 2 \mid \text { chr2:12524889-12527747 } \\
\text { REVERSE LENGTH }=2070\end{array}$ & -0.69 & 0.77 & 1.04 \\
\hline AT1G19070 & $\begin{array}{c}\text { F-box family protein } \\
\text { FORWARD LENGTH=252 }\end{array}$ & -0.66 & 0.08 & 1.17 \\
\hline AT1G52190 & $\begin{array}{cccc}\text { Major facilitator } & \text { superfamily } & \text { protein } & \text { | } \\
\text { chr1:19434509-19438971 } & \text { FORWARD LENGTH=2284 }\end{array}$ & -0.66 & 0.98 & 0.97 \\
\hline AT1G18400 & \begin{tabular}{c|ccc|c} 
BEE1 I BR & enhanced & expression & 1 \\
chr1:6331398-6333743 FORWARD LENGTH=1016
\end{tabular} & -0.65 & 0.83 & 1.31 \\
\hline AT5G19530 & $\begin{array}{l}\text { ACL5 I S-adenosyl-L-methionine-dependent } \\
\text { methyltransferases superfamily protein } \\
\text { chr5:6588958-6591211 REVERSE LENGTH=1358 }\end{array}$ & -0.65 & 0.27 & 0.96 \\
\hline
\end{tabular}




\begin{tabular}{|c|c|c|c|c|}
\hline Identifier & Description & $\begin{array}{l}\text { Col-ColLL } \\
\text { logFC }\end{array}$ & $\begin{array}{l}\text { ColLL-tgaLL } \\
\text { logFC }\end{array}$ & $\begin{array}{l}\text { ColLL-ROXYLL } \\
\text { IOgFC }\end{array}$ \\
\hline AT2G17500 & $\begin{array}{c}\begin{array}{c}\text { Auxin efflux carrier family protein } \\
\text { chr2:7606784-7609278 FORWARD LENGTH=1638 }\end{array} \\
\end{array}$ & -0.65 & 1.46 & 0.22 \\
\hline AT1G33700 & $\begin{array}{c}\text { Beta-glucosidase, GBA2 type family protein } \\
\text { chr1:12208308-12214182 REVERSE LENGTH=3482 }\end{array}$ & -0.64 & 0.87 & 0.55 \\
\hline AT2G34410 & $\begin{array}{ccc}\text { O-acetyltransferase } & \text { family } & \text { protein } \\
\text { chr2:14518406-14522622 FORWARD LENGTH=2391 }\end{array}$ & -0.64 & 0.11 & 1.03 \\
\hline AT3G43740 & $\begin{array}{ccccc}\text { Leucine-rich } & \text { repeat } & \text { (LRR) } & \text { family } & \text { protein } \\
\text { chr3:15644054-15645662 FORWARD LENGTH=946 }\end{array}$ & $\begin{array}{l}-0.64 \\
\end{array}$ & 0.34 & 0.91 \\
\hline AT2G42380 & \begin{tabular}{lc|ccc} 
ATBZIP34, BZIP34 | & Basic-leucine & zipper & (bZIP) \\
transcription & factor & family & protein \\
chr2:17646900-17648945 REVERSE LENGTH=1556
\end{tabular} & -0.64 & 0.79 & 1.22 \\
\hline AT1G67340 & 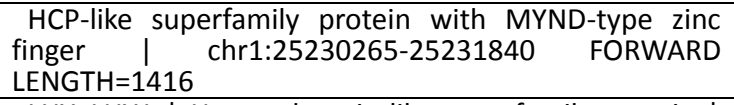 & -0.63 & 0.87 & 0.57 \\
\hline AT1G01060 & $\begin{array}{l}\text { LHY, LHY1 | Homeodomain-like superfamily protein | } \\
\text { chr1:33379-37757 REVERSE LENGTH=2517 }\end{array}$ & -0.63 & 0.80 & 1.55 \\
\hline AT1G78970 & 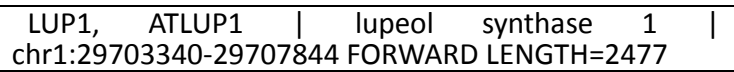 & -0.61 & 1.01 & 1.47 \\
\hline AT3G16360 & \begin{tabular}{c|cc|c} 
AHP4 & HPT & phosphotransmitter & 4 \\
chr3:55544474-5555393 FORWARD LENGTH $=420$
\end{tabular} & -0.61 & 0.76 & 0.94 \\
\hline AT3G62720 & \begin{tabular}{ccc|cc|c} 
ATXT1, & XT1, & XXT1 & xylosyltransferase & 1 & | \\
chr3:23201156-23202913 & FORWARD LENGTH=1660 & \\
\end{tabular} & -0.60 & 0.44 & 0.93 \\
\hline AT3G63440 & \begin{tabular}{lcr|r} 
ATCKX6, CKX6, & ATCKX7 & cytokinin \\
oxidase/dehydrogenase $6 \quad \mid \quad$ chr3:23424157-23426536 \\
FORWARD LENGTH=2007
\end{tabular} & -0.60 & 1.95 & 2.39 \\
\hline AT1G04240 & $\begin{array}{llr}\text { SHY2, IAA3 | } & \text { AUX/IAA transcriptional regulator family } \\
\text { protein | } & \text { chr1:1128188-1129551 } & \text { REVERSE } \\
\text { LENGTH=1178 } & & \end{array}$ & -0.59 & 0.70 & 0.98 \\
\hline AT3G18210 & $\begin{array}{l}\text { 2-oxoglutarate (2OG) and Fe(II)-dependent oxygenase } \\
\text { superfamily protein | chr3:6237930-6240605 REVERSE } \\
\text { LENGTH=1728 }\end{array}$ & -0.59 & 0.71 & 1.00 \\
\hline AT5G20730 & $\begin{array}{l}\text { NPH4, MSG1, IAA21, ARF7, TIR5, BIP | Transcriptional } \\
\text { factor B3 family protein / auxin-responsive factor } \\
\text { AUX/IAA-related | chr5:7016445-7022042 REVERSE } \\
\text { LENGTH=4292 }\end{array}$ & -0.59 & 1.85 & 0.69 \\
\hline AT1G26945 & $\begin{array}{l}\text { KDR I basic helix-loop-helix (bHLH) DNA-binding } \\
\text { superfamily protein I chr1:9351454-9352761 } \\
\text { FORWARD LENGTH=689 }\end{array}$ & -0.58 & 0.98 & 2.10 \\
\hline AT3G01472 & $\begin{array}{l}\text { CPuORF33 | conserved peptide upstream open } \\
\text { reading frame } 33 \text { | chr3:182396-184403 REVERSE } \\
\text { LENGTH=1440 }\end{array}$ & -0.57 & 0.87 & 0.68 \\
\hline AT1G63300 & $\begin{array}{c}\text { Myosin heavy chain-related protein } \\
\text { chr1:23482193-23486220 FORWARD LENGTH=3243 }\end{array}$ & -0.56 & 0.99 & 0.93 \\
\hline AT5G54510 & $\begin{array}{l}\text { GH3.6, DFL1 | Auxin-responsive GH3 family protein | } \\
\text { chr5:22131093-22133678 REVERSE LENGTH=2181 }\end{array}$ & -0.56 & 1.18 & 1.52 \\
\hline AT3G12710 & $\begin{array}{cccc}\text { DNA } & \text { glycosylase } & \text { superfamily } & \text { protein } \\
\text { chr3:4040324-4041982 } & \text { REVERSE LENGTH=1341 } & \\
\end{array}$ & -0.56 & 0.72 & 0.95 \\
\hline AT3G28700 & $\begin{array}{c}\text { Protein of unknown function } \\
\text { chr3:10759559-10762114 FORWARD LENGTH=1717) }\end{array}$ & -0.55 & 1.17 & 1.19 \\
\hline AT2G14890 & \begin{tabular}{c|cc|c|} 
AGP9 & arabinogalactan protein & 9 & | \\
chr2:6399621-6401059 FORWARD LENGTH=938
\end{tabular} & -0.55 & 0.39 & 0.97 \\
\hline AT4G09890 & $\begin{array}{c}\begin{array}{c}\text { Protein of unknown function } \\
\text { chr4:6218396-6218927 FORWARD LENGTH=532 }\end{array} \\
\end{array}$ & -0.55 & 0.95 & 0.87 \\
\hline AT1G20190 & $\begin{array}{l}\text { ATEXPA11, EXP11, ATEXP11, ATHEXP ALPHA 1.14, } \\
\text { EXPA11 | expansin } 11 \mid \text { chr1:6998489-6999817 } \\
\text { REVERSE LENGTH=1139 }\end{array}$ & -0.55 & 0.68 & 0.97 \\
\hline AT1G37150 & \begin{tabular}{c|ccc} 
HCS2 & holocarboxylase & synthetase ${ }^{2}$ & | \\
chr1:14174981-14177302 REVERSE LENGTH=1101 &
\end{tabular} & -0.55 & 1.56 & 0.59 \\
\hline AT5G48560 & $\begin{array}{l}\text { basic helix-loop-helix (bHLH) DNA-binding superfamily } \\
\text { protein | chr5:19684006-19687151 } \\
\text { LENGTH=1931 }\end{array}$ & -0.54 & 0.87 & 1.05 \\
\hline AT3G45050 & $\begin{array}{l}\text { unknown protein; FUNCTIONS IN: molecular_function } \\
\text { unknown; INVOLVED IN: biological_process unknown; } \\
\text { LOCATED IN: chloroplast; EXPRESSED IN: } 22 \text { plant } \\
\text { structures; EXPRESSED DURING: } 13 \text { growth stages; Has } \\
28 \text { Blast hits to } 28 \text { proteins in } 12 \text { species: Archae - } 0 \text {; } \\
\text { Bacteria - 2; Metazoa - 0; Fungi - 0; Plants - 26; Viruses- } \\
\text { 0; Other Eukaryotes - } 0 \text { (source: NCBI BLink). I } \\
\text { chr3:16475966-16477524 FORWARD LENGTH=951 }\end{array}$ & -0.53 & 0.65 & 1.50 \\
\hline AT5G42690 & $\begin{array}{cccc}\text { Protein of unknown function, } & \text { DUF547 } \\
\text { chr5:17116428-17119838 REVERSE LENGTH=2102 }\end{array}$ & -0.53 & 1.41 & 0.53 \\
\hline AT2G45315 & \begin{tabular}{cc|cc} 
other & RNA & chr2:18682108-18683810 & REVERSE \\
LENGTH $=1448$
\end{tabular} & -0.50 & 0.91 & 0.33 \\
\hline
\end{tabular}




\begin{tabular}{|c|c|c|c|c|}
\hline Identifier & Description & $\begin{array}{l}\text { Col-ColLL } \\
\text { logFC }\end{array}$ & $\begin{array}{l}\text { ColLL-tgaLL } \\
\text { logFC }\end{array}$ & $\begin{array}{l}\text { CoILL-ROXYLL } \\
\text { logFC }\end{array}$ \\
\hline AT3G06770 & $\begin{array}{cccc}\text { Pectin lyase-like } & \text { superfamily } & \text { protein } \\
\text { chr3:2134800-2137228 } & \text { REVERSE LENGTH }=1855\end{array}$ & -0.49 & 0.34 & 1.05 \\
\hline AT3G62720 & $\begin{array}{cccc}\text { ATXT1, XT1, XXT1 | } & \text { xylosyltransferase } 1 & \text { | } \\
\text { chr3:23201117-23202907 } & \text { FORWARD LENGTH=1791 }\end{array}$ & -0.49 & 0.50 & 0.87 \\
\hline AT4G31000 & 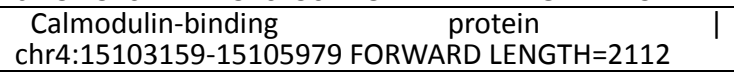 & -0.49 & 0.37 & 0.95 \\
\hline AT4G02330 & $\begin{array}{l}\text { ATPMEPCRB I Plant invertase/pectin methylesterase } \\
\text { inhibitor superfamily | chr4:1032413-1035037 } \\
\text { FORWARD LENGTH=1897 }\end{array}$ & -0.48 & 0.62 & 0.89 \\
\hline AT4G38400 & $\begin{array}{l}\text { ATEXLA2, EXPL2, ATEXPL2, ATHEXP BETA 2.2, EXLA2 | } \\
\text { expansin-like A2 | chr4:17978443-17979740 REVERSE } \\
\text { LENGTH=1105 }\end{array}$ & -0.47 & 0.60 & 0.90 \\
\hline AT1G19840 & $\begin{array}{cccc}\text { SAUR-like } & \text { auxin-responsive } & \text { protein } & \text { family } \\
\text { chr1:6872794-6873255 REVERSE LENGTH=462 } & \end{array}$ & -0.46 & 0.68 & 0.90 \\
\hline AT3G15540 & $\begin{array}{c}\text { IAA19, MSG2 | indole-3-acetic acid inducible } 19 \text { | } \\
\text { chr3:5264024-5265678 FORWARD LENGTH=970 }\end{array}$ & -0.46 & 1.13 & 1.37 \\
\hline AT1G61240 & $\begin{array}{ccc}\text { Protein of unknown function (DUF707) } \\
\text { chr1:22582024-22585203 FORWARD LENGTH=1674 }\end{array}$ & -0.46 & 0.25 & 1.05 \\
\hline AT5G61910 & $\begin{array}{l}\text { DCD (Development and Cell Death) domain protein I } \\
\text { chr5:24859878-24864120 REVERSE LENGTH=2899 }\end{array}$ & -0.46 & 1.23 & 0.31 \\
\hline AT2G38325 & 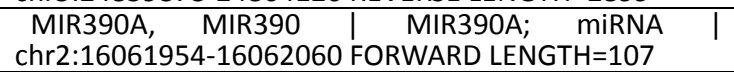 & -0.46 & 0.59 & 0.92 \\
\hline AT3G25620 & $\begin{array}{ccc}\text { ABC-2 type transporter family protein } \\
\text { chr3:9316074-9319571 REVERSE LENGTH=2688 }\end{array}$ & -0.45 & 1.16 & 1.14 \\
\hline AT1G72880 & $\begin{array}{l}\text { Survival protein SurE-like phosphatase/nucleotidase | } \\
\text { chr1:27423385-27426140 REVERSE LENGTH=1663 }\end{array}$ & -0.45 & 1.24 & 0.30 \\
\hline AT5G48900 & $\begin{array}{cccc}\text { Pectin lyase-like } & \text { superfamily } & \text { protein } & \text { | } \\
\text { chr5:19825137-19829092 FORWARD LENGTH=1540 }\end{array}$ & -0.44 & 0.93 & 1.18 \\
\hline AT4G35900 & 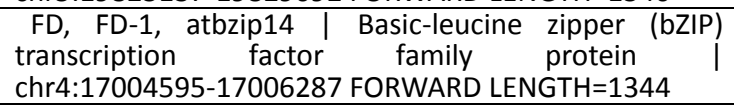 & -0.44 & 1.37 & 0.89 \\
\hline AT2G14890 & \begin{tabular}{c|c|} 
AGP9 arabinogalactan protein 9 & 9 \\
chr2:6399621-6400982 FORWARD LENGTH $=1362$
\end{tabular} & -0.44 & 0.56 & 0.87 \\
\hline AT4G19880 & $\begin{array}{c}\text { Glutathione } \begin{array}{c}\text { S-transferase family protein } \\
\text { chr4:10784391-10786423 REVERSE LENGTH }=1496\end{array}\end{array}$ & -0.44 & 0.67 & 1.22 \\
\hline AT5G62170 & $\begin{array}{l}\text { unknown protein; BEST Arabidopsis thaliana protein } \\
\text { match is: unknown protein (TAIR:AT5G51850.1); Has } \\
381 \text { Blast hits to } 359 \text { proteins in } 81 \text { species: Archae - 0; } \\
\text { Bacteria - 16; Metazoa - 101; Fungi - 21; Plants - 99; } \\
\text { Viruses - 3; Other Eukaryotes - 141 (source: NCBI } \\
\text { BLink). I chr5:24972977-24975549 REVERSE } \\
\text { LENGTH=2324 }\end{array}$ & -0.43 & 0.92 & 0.98 \\
\hline AT1G27580 & $\begin{array}{cccc}\text { Protein of unknown function } & \text { (DUF295) } \\
\text { chr1:9589933-9591075 REVERSE LENGTH=1095 }\end{array}$ & -0.43 & 0.56 & 0.90 \\
\hline AT3G45160 & $\begin{array}{ccc}\text { Putative } & \text { membrane } & \text { lipoprotein } \\
\text { chr3:16533451-16534082 REVERSE LENGTH }=549\end{array}$ & -0.43 & 0.88 & 0.52 \\
\hline AT1G64640 & $\begin{array}{l}\text { ENODL8, AtENODL8 | early nodulin-like protein } 8 \text { | } \\
\text { chr1:24022285-24023196 REVERSE LENGTH=818 }\end{array}$ & -0.42 & 0.86 & 1.33 \\
\hline AT1G02920 & 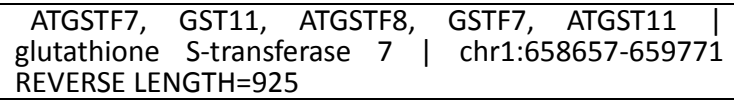 & -0.41 & 0.99 & 0.01 \\
\hline AT3G28420 & $\begin{array}{ccc}\text { Putative } & \text { membrane } & \text { lipoprotein } \\
\text { chr3:10654470-10655388 REVERSE LENGTH=919 }\end{array}$ & -0.41 & 0.97 & 1.88 \\
\hline AT2G40610 & $\begin{array}{l}\text { ATEXPA8, EXP8, ATEXP8, ATHEXP ALPHA 1.11, EXPA8 | } \\
\text { expansin A8 | chr2:16948863-16950557 REVERSE } \\
\text { LENGTH=1105 }\end{array}$ & -0.41 & 1.20 & 1.36 \\
\hline AT1G01120 & $\begin{array}{l}\text { KCS1 | 3-ketoacyl-CoA synthase } 1 \text { | chr1:57269-59167 } \\
\text { REVERSE LENGTH=1899 }\end{array}$ & -0.41 & 0.89 & 1.04 \\
\hline AT1G11545 & $\begin{array}{l}\text { XTH8 | xyloglucan endotransglucosylase/hydrolase } 8 \text { | } \\
\text { chr1:3878550-3880361 REVERSE LENGTH=1132 }\end{array}$ & -0.40 & 0.94 & 1.14 \\
\hline AT4G16745 & $\begin{array}{l}\text { Exostosin family protein | chr4:9411840-9414897 } \\
\text { FORWARD LENGTH=2173 }\end{array}$ & -0.40 & 1.00 & 0.30 \\
\hline AT2G03140 & $\begin{array}{c}\text { alpha/beta-Hydrolases superfamily } \\
\text { chr2:941912-950034 FORWARD LENGTH }=6056\end{array}$ & -0.39 & 1.03 & 1.13 \\
\hline AT1G78040 & $\begin{array}{l}\text { Pollen Ole e } 1 \text { allergen and extensin family protein I } \\
\text { chr1:29345838-29347107 FORWARD LENGTH=938 }\end{array}$ & -0.38 & 0.96 & 0.86 \\
\hline AT3G15605 & $\begin{array}{c}\text { nucleic acid binding } \\
\text { FORWARD LENGTH=1667 }\end{array}$ & -0.37 & 1.43 & 0.87 \\
\hline AT4G00820 & \begin{tabular}{c|c|c} 
iqd17 | IQ-domain 17 & chr4:349116-351550 \\
FORWARD LENGTH=2032 & & \\
\end{tabular} & -0.34 & 0.83 & 0.97 \\
\hline AT3G49110 & $\begin{array}{l}\text { PRX33, PRXCA, ATPRX33, ATPCA I peroxidase CA I } \\
\text { chr3:18200664-18203142 FORWARD LENGTH }=1365\end{array}$ & -0.31 & 1.92 & 1.34 \\
\hline
\end{tabular}




\begin{tabular}{|c|c|c|c|c|}
\hline Identifier & Description & $\begin{array}{l}\text { Col-ColLL } \\
\text { logFC }\end{array}$ & $\begin{array}{l}\text { ColLL-tgaLL } \\
\text { logFC }\end{array}$ & $\begin{array}{l}\text { CoILL-ROXYLL } \\
\text { logFC } \\
\end{array}$ \\
\hline AT5G09220 & \begin{tabular}{c|ccc} 
AAP2 & amino & acid & permease \\
chr5:2866252-2869054 FORWARD LENGTH $=1794$
\end{tabular} & -0.31 & 1.24 & 1.13 \\
\hline AT3G10580 & $\begin{array}{ccc}\text { Homeodomain-like } & \text { superfamily } & \text { protein } \\
\text { chr3:3307051-3308233 } & \text { REVERSE LENGTH }=899\end{array}$ & -0.30 & 0.49 & 0.91 \\
\hline AT5G55230 & $\begin{array}{l}\text { ATMAP65-1, } \\
\text { proteins } 65-1\end{array}$ & -0.27 & 1.04 & 0.38 \\
\hline AT1G78500 & $\begin{array}{cccc}\text { Terpenoid } & \text { cyclases } & \text { family } & \text { protein } \\
\text { chr1:29531646-29535177 FORWARD LENGTH=2304 }\end{array}$ & -0.27 & 0.72 & 0.38 \\
\hline AT3G61160 & $\begin{array}{cccc}\text { Protein } & \text { kinase } & \text { superfamily } & \text { protein } \\
\text { chr3:22635881-22638817 FORWARD LENGTH=1848 }\end{array}$ & -0.26 & -0.26 & 0.95 \\
\hline AT3G27430 & $\begin{array}{l}\text { PBB1 | N-terminal nucleophile aminohydrolases (Ntn } \\
\text { hydrolases) } \quad \text { superfamily }\end{array}$ & -0.24 & 0.19 & 1.29 \\
\hline AT2G31370 & 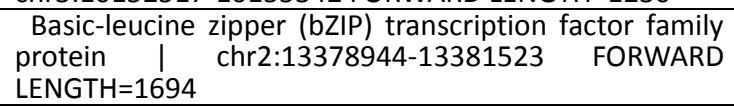 & -0.24 & 1.02 & 0.35 \\
\hline AT3G58810 & $\begin{array}{l}\text { MTPA2, ATMTPA2, MTP3, ATMTP3 | metal tolerance } \\
\text { protein A2 | chr3:21749966-21752006 FORWARD } \\
\text { LENGTH }=2041\end{array}$ & -0.23 & -0.01 & 1.44 \\
\hline AT3G24900 & \begin{tabular}{cc|cccc} 
AtRLP39, & RLP39 & receptor like protein & 39 & I \\
chr3:9099183-9101837 REVERSE LENGTH=2655 & & & \\
\end{tabular} & -0.17 & 0.74 & 0.51 \\
\hline AT3G25710 & $\begin{array}{l}\text { BHLH32, ATAIG1, TMO5 I basic helix-loop-helix } 32 \text { | } \\
\text { chr3:9369519-9371394 FORWARD LENGTH=1412 }\end{array}$ & -0.17 & 1.03 & 0.95 \\
\hline AT1G14400 & $\begin{array}{cccccc}\text { UBC1, ATUBC1 I ubiquitin carrier protein } & 1 & \text { I } \\
\text { chr1:4927011-4928690 REVERSE LENGTH=995 } & & \end{array}$ & -0.14 & 0.20 & 1.30 \\
\hline AT4G34660 & \begin{tabular}{ccc|} 
SH3 & domain-containing & protein \\
chr4:16545197-16548453 REVERSE LENGTH=1595
\end{tabular} & -0.10 & 0.73 & 0.35 \\
\hline AT1G70730 & $\begin{array}{l}\text { PGM2 | Phosphoglucomutase/phosphomannomutase } \\
\text { family protein | chr1:26668865-26672779 REVERSE } \\
\text { LENGTH=1966 }\end{array}$ & -0.10 & 0.81 & 0.24 \\
\hline AT2G28840 & $\begin{array}{c}\text { XBAT31 | XB3 ortholog } 1 \text { in Arabidopsis thaliana | } \\
\text { chr2:12378337-12380742 FORWARD LENGTH }=1844\end{array}$ & -0.09 & 0.63 & 0.26 \\
\hline AT3G04720 & \begin{tabular}{ccc|ccc|} 
PR4, & HEL, & PR-4 & pathogenesis-related & 4 & I \\
chr3:1285524-1286562 & REVERSE LENGTH=837 & & & \\
\end{tabular} & -0.03 & 0.78 & 0.34 \\
\hline AT5G55390 & \begin{tabular}{c|cccc} 
EDM2 & ENHANCED & DOWNY MILDEW & 2 & I \\
chr5:22447966-22454802 & REVERSE LENGTH=4258 & &
\end{tabular} & 0.04 & 0.26 & 0.58 \\
\hline AT3G26900 & \begin{tabular}{cc|cccc|} 
SKL1, & ATSKL1 I & shikimate & kinase like & 1 & | \\
chr3:9912209-9914514 REVERSE LENGTH=1038 & & &
\end{tabular} & 0.06 & 0.91 & 0.78 \\
\hline AT2G29452 & $\begin{array}{l}\text { unknown protein; Has } 30201 \text { Blast hits to } 17322 \\
\text { proteins in } 780 \text { species: Archae - } 12 \text {; Bacteria - 1396; } \\
\text { Metazoa - } 17338 \text {; Fungi - 3422; Plants - 5037; Viruses - } \\
\text { 0; Other Eukaryotes - } 2996 \text { (source: NCBI BLink). I } \\
\text { chr2:12625854-12625985 REVERSE LENGTH=132 }\end{array}$ & 0.14 & -0.22 & 0.21 \\
\hline
\end{tabular}

Table S3 List of 175 genes of cluster 8.

\begin{tabular}{|c|c|c|c|}
\hline Identifier & Description & $\begin{array}{l}\text { ColLL-tgaLL } \\
\text { logFC }\end{array}$ & $\begin{array}{l}\text { CoILL-ROXYLL } \\
\operatorname{logFC}\end{array}$ \\
\hline AT4G15680 & $\begin{array}{l}\text { Thioredoxin superfamily } \\
\text { FORWARD LENGTH=644 }\end{array}$ & -4.98 & -4.89 \\
\hline AT1G14250 & $\begin{array}{c}\text { GDA1/CD39 nucleoside phosphatase family protein } \\
\text { chr1:4868452-4871488 FORWARD LENGTH=1846 }\end{array}$ & -3.89 & -3.65 \\
\hline AT4G15670 & $\begin{array}{l}\text { Thioredoxin superfamily } \\
\text { FORWARD LENGTH }=587\end{array}$ & -3.88 & -3.87 \\
\hline AT4G15700 & $\begin{array}{l}\begin{array}{l}\text { Thioredoxin superfamily } \\
\text { FORWARD LENGTH }=500\end{array} \\
\end{array}$ & -3.60 & -3.79 \\
\hline AT4G01430 & $\begin{array}{cccccc}\begin{array}{c}\text { nodulin } \\
\text { chr4:N21 }\end{array} \text { /EamA-like transporter family } & \text { protein } & \text { I } \\
\end{array}$ & -3.46 & -3.80 \\
\hline AT4G15690 & $\begin{array}{l}\text { Thioredoxin superfamily protein } \quad \text { chr4:8934324-8934921 } \\
\text { FORWARD LENGTH=598 }\end{array}$ & -3.28 & -3.24 \\
\hline AT3G14075 & 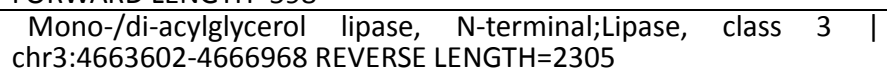 & -3.25 & -2.51 \\
\hline AT4G15660 & $\begin{array}{l}\text { Thioredoxin superfamily protein } \quad \text { chr4:8925806-8926310 } \\
\text { FORWARD LENGTH=505 }\end{array}$ & -3.21 & -3.16 \\
\hline AT4G23600 & $\begin{array}{ccccc}\text { CORI3, JR2 I Tyrosine transaminase family } & \text { protein I } \\
\text { chr4:12310619-12313212 FORWARD LENGTH }=1660 & & \\
\end{array}$ & -2.98 & -2.64 \\
\hline AT1G15380 & $\begin{array}{c}\text { Lactoylglutathione lyase / glyoxalase I family } \\
\text { chr1:5290745-5292535 FORWARD LENGTH=983 }\end{array}$ & -2.86 & -2.55 \\
\hline AT1G10070 & $\begin{array}{l}\text { ATBCAT-2, BCAT-2 | branched-chain amino acid transaminase } 2 \text { | } \\
\text { chr1:3288087-3290471 FORWARD LENGTH=1668 }\end{array}$ & -2.39 & -2.14 \\
\hline
\end{tabular}




\begin{tabular}{|c|c|c|c|}
\hline Identifier & Description & $\begin{array}{l}\text { ColLL-tgaLL } \\
\text { logFC }\end{array}$ & $\begin{array}{l}\text { CoILL-ROXYLL } \\
\operatorname{logFC}\end{array}$ \\
\hline AT4G09510 & $\begin{array}{l}\text { CINV2 | cytosolic invertase } 2 \text { | chr4:6021164-6023873 REVERSE } \\
\text { LENGTH=2032 }\end{array}$ & -2.33 & -2.18 \\
\hline AT1G66100 & Plant thionin | chr1:24605671-24606537 REVERSE LENGTH=674 & -2.32 & -1.75 \\
\hline AT1G71880 & \begin{tabular}{cc|ccc|c} 
SUC1, & ATSUC1 & sucrose-proton & symporter & 1 & $\mid$ \\
chr1:27054180-27056341 FORWARD LENGTH=1937 & & & \\
\end{tabular} & -2.31 & -2.55 \\
\hline AT4G11320 & 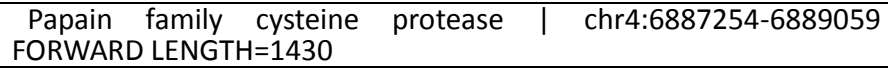 & -2.31 & -2.50 \\
\hline AT5G13220 & $\begin{array}{cccccc}\text { JAZ10, TIFY9, JAS1 I jasmonate-zim-domain } & \text { protein } & 10 & \text { I } \\
\text { chr5:4218888-4220700 FORWARD LENGTH=1375 } & & & & \\
\end{array}$ & -2.22 & -1.48 \\
\hline AT4G28040 & $\begin{array}{cccccc}\text { nodulin MtN21 } & \text { /EamA-like transporter family } & \text { protein } \\
\text { chr4:13940601-13942436 FORWARD LENGTH=1462 } & & \\
\end{array}$ & -2.18 & -1.69 \\
\hline AT3G62950 & $\begin{array}{l}\begin{array}{l}\text { Thioredoxin superfamily } \\
\text { FORWARD LENGTH=686 }\end{array} \\
\text { PORWein }\end{array}$ & -2.14 & -2.22 \\
\hline AT2G36080 & $\begin{array}{c}\text { AP2/B3-like transcriptional factor family protein } \\
\text { chr2:15150551-15151575 REVERSE LENGTH=1025 }\end{array}$ & -2.11 & -1.76 \\
\hline AT2G36080 & $\begin{array}{cccc}\text { AP2/B3-like transcriptional factor family } & \text { protein } \\
\text { chr2:15148259-15151575 REVERSE LENGTH=1252 } & & \\
\end{array}$ & -2.05 & -1.54 \\
\hline AT4G26260 & $\begin{array}{l}\text { MIOX4 I myo-inositol oxygenase } 4 \text { | chr4:13297803-13300319 } \\
\text { FORWARD LENGTH=1266 }\end{array}$ & -2.04 & -1.70 \\
\hline AT3G09260 & $\begin{array}{l}\text { PYK10, PSR3.1, BGLU23, LEB | Glycosyl hydrolase superfamily } \\
\text { protein | chr3:2840477-2843781 REVERSE LENGTH=1806 }\end{array}$ & -1.99 & -1.57 \\
\hline AT4G17190 & $\begin{array}{l}\text { FPS2 | farnesyl diphosphate synthase } 2 \text { | chr4:9648527-9650912 } \\
\text { REVERSE LENGTH=1292 }\end{array}$ & -1.93 & -1.51 \\
\hline AT5G24780 & \begin{tabular}{cc|cccc|}
$\begin{array}{c}\text { VSP1, } \\
\text { chr5:850759P1 }\end{array}$ vegetative & storage & protein & 1 & I \\
\end{tabular} & -1.84 & -2.04 \\
\hline AT3G18280 & $\begin{array}{l}\text { Bifunctional inhibitor/lipid-transfer protein/seed storage } 2 S \\
\text { albumin superfamily protein | chr3:6267049-6267643 FORWARD } \\
\text { LENGTH }=595\end{array}$ & -1.82 & -1.76 \\
\hline AT5G44572 & $\begin{array}{l}\text { unknown protein; FUNCTIONS IN: molecular_function unknown; } \\
\text { INVOLVED IN: biological_process unknown; LOCATED IN: } \\
\text { endomembrane system; Has } 7 \text { Blast hits to } 7 \text { proteins in } 2 \text { species: } \\
\text { Archae - 0; Bacteria - 0; Metazoa - 0; Fungi - 0; Plants - 7; Viruses - 0; } \\
\text { Other Eukaryotes - O (source: NCBI BLink). } \\
\text { chr5:17968152-17969563 FORWARD LENGTH }=537 \quad l\end{array}$ & -1.78 & -1.98 \\
\hline AT5G21960 & $\begin{array}{cccc}\text { Integrase-type } & \text { DNA-binding } & \text { superfamily } & \text { protein } \\
\text { chr5:7258363-7259308 REVERSE LENGTH=946 } & & \\
\end{array}$ & -1.76 & -1.55 \\
\hline AT3G15950 & \begin{tabular}{l|l|l} 
NAl2 I DNA topoisomerase-related & chr3:5397569-5402652 \\
REVERSE LENGTH=2461 & \\
\end{tabular} & -1.75 & -1.46 \\
\hline AT3G30775 & 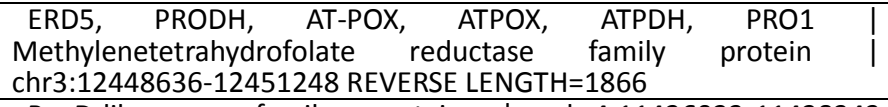 & -1.75 & -1.76 \\
\hline AT4G21450 & \begin{tabular}{cr|c} 
PapD-like superfamily & protein & chr4:11426023-11428343 \\
FORWARD LENGTH=1480
\end{tabular} & -1.74 & -1.42 \\
\hline AT2G47750 & $\begin{array}{l}\text { GH3.9 | putative indole-3-acetic acid-amido synthetase GH3.9 | } \\
\text { chr2:19560127-19563191 REVERSE LENGTH=2155 }\end{array}$ & -1.73 & -1.72 \\
\hline AT5G18600 & $\begin{array}{l}\text { Thioredoxin superfamily protein | chr5:6183258-6183954 REVERSE } \\
\text { LENGTH=697 }\end{array}$ & -1.72 & -1.53 \\
\hline AT5G02260 & $\begin{array}{l}\text { ATEXPA9, EXP9, ATEXP9, ATHEXP ALPHA 1.10, EXPA9 | expansin A9 } \\
\text { | chr5:463158-465246 FORWARD LENGTH=1249 }\end{array}$ & -1.72 & -1.24 \\
\hline AT4G15530 & \begin{tabular}{c|ccc|} 
PPDK & pyruvate & orthophosphate & dikinase \\
chr4:8864828-8870861 REVERSE LENGTH=2908 & & \\
\end{tabular} & -1.70 & -1.71 \\
\hline AT5G60100 & $\begin{array}{l}\text { PRR3 | pseudo-response regulator } 3 \text { | chr5:24197998-24201364 } \\
\text { REVERSE LENGTH=2182 }\end{array}$ & -1.69 & -1.08 \\
\hline AT3G47340 & $\begin{array}{l}\text { ASN1, DIN6, AT-ASN1 | glutamine-dependent asparagine synthase } \\
1 \mid \text { chr3:17437884-17441242 REVERSE LENGTH=2299 }\end{array}$ & -1.68 & -0.78 \\
\hline AT1G33440 & $\begin{array}{l}\text { Major facilitator superfamily protein | chr1:12127389-12130407 } \\
\text { REVERSE LENGTH }=2209\end{array}$ & -1.65 & -1.78 \\
\hline AT3G15950 & \begin{tabular}{l|l|l} 
NAl2 I DNA topoisomerase-related & chr3:5397569-5402652 \\
REVERSE LENGTH $=2575$ &
\end{tabular} & -1.64 & -1.74 \\
\hline AT3G44990 & $\begin{array}{l}\text { XTR8, ATXTR8, XTH31 | xyloglucan endo-transglycosylase-related } 8 \\
\text { | chr3:16446975-16448764 REVERSE LENGTH=1273 }\end{array}$ & -1.63 & -1.52 \\
\hline AT5G23810 & 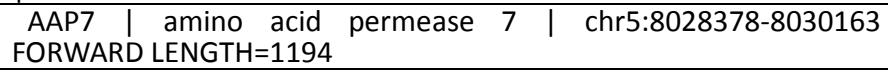 & -1.63 & -1.32 \\
\hline AT3G62930 & $\begin{array}{l}\begin{array}{l}\text { Thioredoxin superfamily } \\
\text { REVERSE LENGTH }=486\end{array} \\
\text { protein }\end{array}$ & -1.61 & -1.49 \\
\hline AT4G24050 & \begin{tabular}{cccc|} 
NAD(P)-binding & Rossmann-fold & superfamily & protein \\
chr4:12497055-12500128 FORWARD LENGTH=1698 & & \\
\end{tabular} & -1.59 & -1.56 \\
\hline AT5G11870 & \begin{tabular}{cc|c} 
Alkaline phytoceramidase & (aPHC) & chr5:3825532-3827306 \\
FORWARD LENGTH $=1042$ & & \\
\end{tabular} & -1.59 & -1.37 \\
\hline AT1G43910 & $\begin{array}{l}\text { P-loop containing nucleoside triphosphate hydrolases superfamily } \\
\text { protein | chr1:16655884-16657658 REVERSE LENGTH=1624 }\end{array}$ & -1.56 & -1.80 \\
\hline AT1G15380 & \begin{tabular}{cccc|} 
Lactoylglutathione lyase / glyoxalase I family protein \\
chr1:5290747-5292535 FORWARD LENGTH=864
\end{tabular} & -1.55 & -1.97 \\
\hline
\end{tabular}




\begin{tabular}{|c|c|c|c|}
\hline Identifier & Description & $\begin{array}{l}\text { ColLL-tgaLL } \\
\quad \text { logFC }\end{array}$ & $\begin{array}{l}\text { ColLL-ROXYLL } \\
\text { logFC }\end{array}$ \\
\hline AT2G43820 & $\begin{array}{l}\text { GT, UGT74F2, ATSAGT1, SGT1, SAGT1 I UDP-glucosyltransferase } \\
\text { 74F2 | chr2:18152227-18153908 FORWARD LENGTH=1595 }\end{array}$ & -1.50 & -1.44 \\
\hline AT4G32920 & 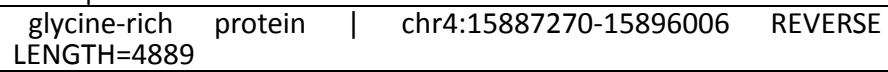 & -1.50 & -1.34 \\
\hline AT4G36850 & $\begin{array}{l}\text { PQ-loop repeat family protein / transmembrane family protein I } \\
\text { chr4:17353291-17355891 REVERSE LENGTH=1372 }\end{array}$ & -1.49 & -1.55 \\
\hline AT4G17470 & \begin{tabular}{ccc|} 
alpha/beta-Hydrolases & superfamily & protein \\
chr4:9742759-9744860 REVERSE LENGTH=1212 & & \\
\end{tabular} & -1.49 & -0.86 \\
\hline AT5G19110 & $\begin{array}{cccc}\text { Eukaryotic aspartyl protease } & \text { family } & \text { protein } \\
\text { chr5:6411561-6413170 REVERSE LENGTH }=1377 & \\
\end{array}$ & -1.48 & -1.38 \\
\hline AT5G41080 & $\begin{array}{ccclc}\begin{array}{c}\text { PLC-like phosphodiesterases } \\
\text { chr5:16441808-16443985 FORWARD LENGTH=1408 }\end{array} & \text { protein } & \text { I } \\
\end{array}$ & -1.46 & -1.13 \\
\hline AT1G24575 & $\begin{array}{l}\text { unknown protein; Has } 7 \text { Blast hits to } 7 \text { proteins in } 2 \text { species: Archae } \\
\text { - 0; Bacteria - 0; Metazoa - 0; Fungi - 0; Plants - 7; Viruses - 0; Other } \\
\text { Eukaryotes - O (source: NCBI BLink). I chr1:8711036-8711528 } \\
\text { REVERSE LENGTH=493 }\end{array}$ & -1.45 & -1.25 \\
\hline AT3G26818 & $\begin{array}{l}\text { MIR169M | MIR169M; miRNA | chr3:9878168-9878379 REVERSE } \\
\text { LENGTH=212 }\end{array}$ & -1.45 & -1.26 \\
\hline AT5G50330 & $\begin{array}{l}\text { Protein kinase superfamily protein } \mid \text { chr5:20485223-20488684 } \\
\text { REVERSE LENGTH }=1744\end{array}$ & -1.44 & -1.11 \\
\hline AT5G14420 & $\begin{array}{l}\text { RGLG2 | RING domain ligase2 | chr5:4648111-4651309 REVERSE } \\
\text { LENGTH=1882 }\end{array}$ & -1.44 & -1.12 \\
\hline AT3G18560 & $\begin{array}{l}\text { unknown protein; BEST Arabidopsis thaliana protein match is: } \\
\text { unknown protein (TAIR:AT1G49000.1); Has 95 Blast hits to } 95 \\
\text { proteins in } 13 \text { species: Archae - 0; Bacteria - 0; Metazoa - 0; Fungi - } \\
\text { 0; Plants - 95; Viruses - 0; Other Eukaryotes - 0 (source: NCBI BLink). } \\
\text { | chr3:6393910-6394785 FORWARD LENGTH }=876\end{array}$ & -1.42 & -1.68 \\
\hline AT3G22550 & $\begin{array}{l}\text { Protein of unknown function (DUF581) | chr3:7991646-7993454 } \\
\text { REVERSE LENGTH=1483 }\end{array}$ & -1.40 & -1.59 \\
\hline AT4G19810 & $\begin{array}{l}\text { Glycosyl hydrolase family protein with chitinase insertion domain | } \\
\text { chr4:10763934-10765753 REVERSE LENGTH=1357 }\end{array}$ & -1.40 & -1.64 \\
\hline AT3G60160 & $\begin{array}{l}\text { ATMRP9, MRP9, ABCC9 | multidrug resistance-associated protein } 9 \\
\mid \text { chr3:22223803-22229204 REVERSE LENGTH=4556 }\end{array}$ & -1.38 & -1.17 \\
\hline AT2G29670 & $\begin{array}{ccccc}\text { Tetratricopeptide repeat (TPR)-like superfamily } & \text { protein } \\
\text { chr2:12681958-12685087 REVERSE LENGTH=2149 } & & \\
\end{array}$ & -1.37 & -1.12 \\
\hline AT5G20250 & $\begin{array}{l}\text { DIN10 | Raffinose synthase family protein | chr5:6833659-6836782 } \\
\text { FORWARD LENGTH=2836 }\end{array}$ & -1.36 & -1.52 \\
\hline AT2G40200 & $\begin{array}{l}\text { basic helix-loop-helix (bHLH) DNA-binding superfamily protein I } \\
\text { chr2:16791098-16792090 FORWARD LENGTH=828 }\end{array}$ & -1.36 & -1.06 \\
\hline AT1G53160 & \begin{tabular}{c|cccc|} 
SPL4 I squamosa promoter binding protein-like & 4 & I \\
chr1:19806419-19807608 FORWARD LENGTH $=857$ & &
\end{tabular} & -1.35 & -1.62 \\
\hline AT1G70700 & $\begin{array}{l}\text { JAZ9, TIFY7 I TIFY domain/Divergent CCT motif family protein I } \\
\text { chr1:26654768-26657064 FORWARD LENGTH=1247 }\end{array}$ & -1.34 & -1.46 \\
\hline AT1G03020 & $\begin{array}{l}\text { Thioredoxin superfamily protein | chr1:698207-698515 REVERSE } \\
\text { LENGTH=309 }\end{array}$ & -1.33 & -1.37 \\
\hline AT1G50000 & \begin{tabular}{l|cc}
$\begin{array}{l}\text { methyltransferases } \\
\text { LENGTH }=1020\end{array}$ & chr1:18515059-18517249 & REVERSE \\
\end{tabular} & -1.32 & -0.83 \\
\hline AT4G36410 & \begin{tabular}{c|ccc|} 
UBC17 I & ubiquitin-conjugating & enzyme & 17 \\
chr4:17201922-17202988 FORWARD LENGTH=631 & &
\end{tabular} & -1.31 & -1.30 \\
\hline AT1G20160 & $\begin{array}{l}\text { ATSBT5.2 I Subtilisin-like serine endopeptidase family protein I } \\
\text { chr1:6990784-6993972 REVERSE LENGTH=2383 }\end{array}$ & -1.30 & -1.34 \\
\hline AT1G19180 & \begin{tabular}{c|ccc|} 
TIFY10A I jasmonate-zim-domain protein & 1 & | \\
chr1:6622114-6623620 FORWARD LENGTH=1507 & & \\
\end{tabular} & -1.29 & -1.13 \\
\hline AT4G30450 & 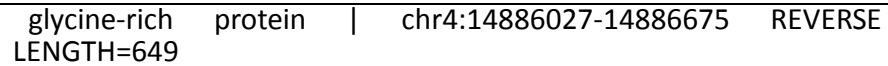 & -1.29 & -1.24 \\
\hline AT3G22410 & $\begin{array}{ccccc}\text { Sec14p-like phosphatidylinositol transfer family protein } & \text { | } \\
\text { chr3:7933167-7935808 REVERSE LENGTH=1508 } & & & \\
\end{array}$ & -1.28 & -1.07 \\
\hline AT1G11080 & $\begin{array}{l}\text { scpl31 | serine carboxypeptidase-like 31 | chr1:3694672-3697808 } \\
\text { REVERSE LENGTH=1674 }\end{array}$ & -1.27 & -0.95 \\
\hline AT4G37520 & $\begin{array}{c}\text { Peroxidase superfamily protein } \\
\text { FORWARD LENGTH=1203 }\end{array}$ & -1.27 & -1.11 \\
\hline AT3G32980 & 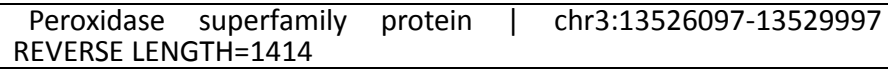 & -1.26 & -0.78 \\
\hline AT1G48140 & $\begin{array}{c}\begin{array}{c}\text { dolichol-phosphate } \\
\text { chr1:17782042-17784211 FORWARD LENGTH=689 }\end{array} \\
\end{array}$ & -1.26 & -0.98 \\
\hline AT1G70700 & \begin{tabular}{c|ccc} 
TIFY7 I TIFY domain/Divergent CCT motif family protein I \\
chr1:26654768-26657064 FORWARD LENGTH=1175
\end{tabular} & -1.25 & -1.43 \\
\hline AT4G33150 & 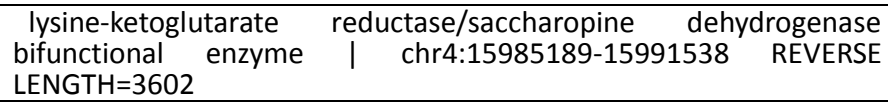 & -1.24 & -0.69 \\
\hline AT5G20250 & $\begin{array}{l}\text { DIN10 | Raffinose synthase family protein | chr5:6833659-6836782 } \\
\text { FORWARD LENGTH=2846 }\end{array}$ & -1.22 & -1.14 \\
\hline
\end{tabular}




\begin{tabular}{|c|c|c|c|}
\hline Identifier & Description & $\begin{array}{l}\text { ColLL-tgaLL } \\
\text { logFC }\end{array}$ & $\begin{array}{l}\text { CoILL-ROXYLL } \\
\operatorname{logFC}\end{array}$ \\
\hline AT3G49620 & \begin{tabular}{l|lll} 
DIN11 | 2-oxoglutarate (2OG) and Fe(II)-dependent & oxygenase \\
superfamily protein I chr3:18393747-18396816 & FORWARD \\
LENGTH=1304 & & & \\
\end{tabular} & -1.22 & -1.17 \\
\hline AT3G02140 & $\begin{array}{l}\text { TMAC2, AFP4 I AFP2 (ABI five-binding protein 2) family protein I } \\
\text { chr3:385317-386538 REVERSE LENGTH=1222 }\end{array}$ & -1.22 & -1.26 \\
\hline AT2G34600 & \begin{tabular}{ccccc|} 
JAZ7, & TIFY5B I jasmonate-zim-domain & protein & 7 & | \\
chr2:14573080-14573856 FORWARD LENGTH=677 & & & \\
\end{tabular} & -1.22 & -0.78 \\
\hline AT5G06870 & $\begin{array}{ccccc}\text { PGIP2, ATPGIP2 I polygalacturonase inhibiting protein } 2 & \text { I } \\
\text { chr5:2133918-2135166 FORWARD LENGTH=1166 } & & & \end{array}$ & -1.21 & -1.14 \\
\hline AT4G38240 & $\begin{array}{l}\text { CGL1, CGL, GNTI I alpha-1,3-mannosyl-glycoprotein } \\
\text { beta-1,2-N-acetylglucosaminyltransferase, } \\
\text { chr4:17931570-17935325 REVERSE LENGTH=1887 }\end{array}$ & -1.21 & -0.97 \\
\hline AT5G02230 & $\begin{array}{l}\text { Haloacid dehalogenase-like hydrolase (HAD) superfamily protein I } \\
\text { chr5:448105-450654 FORWARD LENGTH=1103 }\end{array}$ & -1.20 & -0.46 \\
\hline AT3G57520 & $\begin{array}{l}\text { AtSIP2, SIP2 | seed imbibition } 2 \text { | chr3:21288765-21293158 } \\
\text { REVERSE LENGTH=2699 }\end{array}$ & -1.20 & -1.28 \\
\hline AT2G24960 & $\begin{array}{l}\text { unknown protein; BEST Arabidopsis thaliana protein match is: } \\
\text { unknown protein (TAIR:AT4G02210.2); Has } 1453 \text { Blast hits to } 509 \\
\text { proteins in } 26 \text { species: Archae - 0; Bacteria - 0; Metazoa - } 1 \text {; Fungi - } \\
\text { 39; Plants - } 1363 \text {; Viruses - 0; Other Eukaryotes - } 50 \text { (source: NCBI } \\
\text { BLink). | chr2:10617263-10620034 FORWARD LENGTH=2394 }\end{array}$ & -1.20 & -0.89 \\
\hline AT5G62890 & 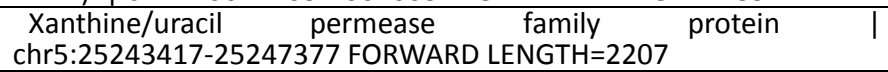 & -1.18 & -0.82 \\
\hline AT5G04770 & $\begin{array}{ccccc}\text { ATCAT6, CAT6 I cationic amino acid transporter } & 6 & \text { | } \\
\text { chr5:1379068-1382419 FORWARD LENGTH=1917 } & & & \end{array}$ & -1.17 & -0.84 \\
\hline AT5G54080 & $\begin{array}{l}\text { HGO | homogentisate 1,2-dioxygenase | chr5:21945869-21948285 } \\
\text { FORWARD LENGTH=1652 }\end{array}$ & -1.17 & -0.89 \\
\hline AT1G61810 & $\begin{array}{l}\text { BGLU45 | beta-glucosidase } 45 \quad \mid \text { chr1:22830015-22834728 } \\
\text { FORWARD LENGTH=1696 }\end{array}$ & -1.17 & -0.84 \\
\hline AT3G26815 & $\begin{array}{l}\text { MIR169K | MIR169K; miRNA | chr3:9875525-9875737 REVERSE } \\
\text { LENGTH=213 }\end{array}$ & -1.16 & -0.95 \\
\hline AT5G59080 & $\begin{array}{l}\text { unknown protein; FUNCTIONS IN: molecular function unknown; } \\
\text { INVOLVED IN: response to oxidative stress; LOCATED IN: chloroplast; } \\
\text { EXPRESSED IN: } 18 \text { plant structures; EXPRESSED DURING: } 9 \text { growth } \\
\text { stages; BEST Arabidopsis thaliana protein match is: unknown } \\
\text { protein (TAIR:AT3G46880.1); Has } 1807 \text { Blast hits to } 1807 \text { proteins in } \\
277 \text { species: Archae - 0; Bacteria - 0; Metazoa - } 736 \text {; Fungi - } 347 \text {; } \\
\text { Plants - 385; Viruses - 0; Other Eukaryotes - 339 (source: NCBI } \\
\text { BLink). | chr5:23847405-23848557 REVERSE LENGTH=848 }\end{array}$ & -1.16 & -0.88 \\
\hline AT4G24230 & $\begin{array}{l}\text { ACBP3 | acyl-CoA-binding domain } 3 \text { | chr4:12566861-12568770 } \\
\text { REVERSE LENGTH=1372 }\end{array}$ & -1.16 & -0.83 \\
\hline AT3G57520 & $\begin{array}{c}\text { AtSIP2, SIP2 | seed imbibition } 2 \text { | chr3:21288765-21293158 } \\
\text { REVERSE LENGTH=2727 }\end{array}$ & -1.15 & -1.19 \\
\hline AT4G35770 & $\begin{array}{l}\text { SEN1, ATSEN1, DIN1 | } \\
\text { superfamily prodein } \\
\text { LENGTH }=894\end{array}$ & -1.14 & -1.05 \\
\hline AT2G15880 & $\begin{array}{l}\text { Leucine-rich repeat (LRR) family protein | chr2:6918039-6920319 } \\
\text { REVERSE LENGTH }=2184\end{array}$ & -1.14 & -1.08 \\
\hline AT1G80050 & $\begin{array}{l}\text { APT2, ATAPT2, PHT1.1 I adenine phosphoribosyl transferase } 2 \text { I } \\
\text { chr1:30111514-30113324 REVERSE LENGTH=836 }\end{array}$ & -1.14 & -1.26 \\
\hline AT5G05600 & $\begin{array}{l}\text { 2-oxoglutarate (2OG) and Fe(II)-dependent oxygenase superfamily } \\
\text { protein | chr5:1672120-1674739 FORWARD LENGTH=1399 }\end{array}$ & -1.13 & -1.10 \\
\hline AT2G47180 & $\begin{array}{l}\text { AtGolS1, GolS1 | galactinol synthase } 1 \text { | chr2:19368798-19370441 } \\
\text { REVERSE LENGTH=1355 }\end{array}$ & -1.13 & -0.96 \\
\hline AT3G28220 & $\begin{array}{l}\text { TRAF-like family protein | chr3:10524404-10526728 FORWARD } \\
\text { LENGTH }=1360\end{array}$ & -1.13 & -0.87 \\
\hline AT1G02610 & $\begin{array}{ccccc}\text { RING/FYVE/PHD } & \text { zinc } & \text { finger } & \text { superfamily } & \text { protein } \\
\text { chr1:553050-555994 REVERSE LENGTH=937 } & \text { I }\end{array}$ & -1.12 & -1.15 \\
\hline AT3G18780 & $\begin{array}{l}\text { ACT2, DER1, LSR2, ENL2 | actin } 2 \text { | chr3:6474871-6477204 } \\
\text { FORWARD LENGTH=1813 }\end{array}$ & -1.11 & -0.72 \\
\hline AT4G37530 & 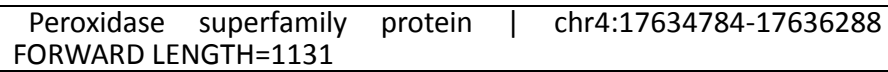 & -1.11 & -0.98 \\
\hline AT3G47340 & $\begin{array}{l}\text { ASN1, DIN6, AT-ASN1 | glutamine-dependent asparagine synthase } \\
1 \mid \text { chr3:17437884-17441242 REVERSE LENGTH=2380 }\end{array}$ & -1.11 & -0.98 \\
\hline AT3G25780 & $\begin{array}{l}\text { AOC3 | allene oxide cyclase } 3 \text { | chr3:9409290-9410567 FORWARD } \\
\text { LENGTH =1007 }\end{array}$ & -1.10 & -0.92 \\
\hline AT3G15270 & \begin{tabular}{c|ccccc|} 
SPL5 | squamosa & promoter binding & protein-like & 5 & | \\
chr3:5140365-5141348 REVERSE LENGTH=897 & & & \\
\end{tabular} & -1.10 & -0.75 \\
\hline AT1G49320 & $\begin{array}{cccccc}\text { ATUSPL1, USPL1 I unknown seed protein like } & 1 & \text { I } \\
\text { chr1:18246305-182479992 FORWARD LENGTH }=1154\end{array}$ & -1.10 & -0.97 \\
\hline AT1G31770 & $\begin{array}{l}\text { ABCG14 | ATP-binding cassette } 14 \mid \text { chr1:11374893-11377794 } \\
\text { REVERSE LENGTH=2456 }\end{array}$ & -1.09 & -1.12 \\
\hline
\end{tabular}




\begin{tabular}{|c|c|c|c|}
\hline Identifier & Description & $\begin{array}{l}\text { ColLL-tgaLL } \\
\operatorname{logFC}\end{array}$ & $\begin{array}{l}\text { CoILL-ROXYLL } \\
\operatorname{logFC}\end{array}$ \\
\hline AT4G19820 & $\begin{array}{l}\text { Glycosyl hydrolase family protein with chitinase insertion domain | } \\
\text { chr4:10767436-10768614 REVERSE LENGTH=1101 }\end{array}$ & -1.09 & -0.92 \\
\hline AT3G16470 & \begin{tabular}{c|ccc} 
JR1 I Mannose-binding lectin superfamily & protein \\
chr3:5595929-5598027 REVERSE LENGTH=1593 & &
\end{tabular} & -1.08 & $\begin{array}{l}-0.99 \\
\end{array}$ \\
\hline AT5G05860 & \begin{tabular}{c|ccc} 
UGT76C2 & UDP-glucosyl & transferase & $76 C 2$ \\
chr5:1765507-1767455 FORWARD LENGTH $=1498$ &
\end{tabular} & -1.08 & -0.98 \\
\hline AT5G22000 & $\begin{array}{l}\text { RHF2A | RING-H2 group F2A | chr5:7277322-7280255 FORWARD } \\
\text { LENGTH=1729 }\end{array}$ & -1.08 & -0.66 \\
\hline AT1G17380 & \begin{tabular}{cc|cccc|} 
JAZ5, TIFY11A I jasmonate-zim-domain & protein & 5 & l \\
chr1:5955488-5957212 REVERSE LENGTH=1133 & & & \\
\end{tabular} & -1.07 & -0.86 \\
\hline AT5G23350 & $\begin{array}{l}\text { GRAM domain-containing protein / ABA-responsive protein-related } \\
\text { chr5:7858253-7859387 REVERSE LENGTH=1135 }\end{array}$ & -1.07 & -0.94 \\
\hline AT1G30110 & $\begin{array}{l}\text { NUDX25 | nudix hydrolase homolog } 25 \text { | chr1:10581735-10583949 } \\
\text { FORWARD LENGTH=847 }\end{array}$ & -1.07 & -1.09 \\
\hline AT5G23820 & $\begin{array}{l}\text { MD-2-related lipid recognition domain-containing protein } \\
\text { chr5:8031268-8033020 FORWARD LENGTH=824 }\end{array}$ & -1.05 & -1.16 \\
\hline AT2G28120 & $\begin{array}{l}\text { Major facilitator superfamily protein | chr2:11985687-11987738 } \\
\text { FORWARD LENGTH=2052 }\end{array}$ & -1.04 & -0.99 \\
\hline AT1G51620 & $\begin{array}{l}\text { Protein kinase superfamily protein | chr1:19140130-19141787 } \\
\text { FORWARD LENGTH=1344 }\end{array}$ & -1.03 & -1.15 \\
\hline AT4G20860 & $\begin{array}{l}\text { FAD-binding Berberine family protein | chr4:11172622-11174467 } \\
\text { FORWARD LENGTH=1846 }\end{array}$ & -1.03 & -0.61 \\
\hline AT2G29995 & $\begin{array}{l}\text { unknown protein; FUNCTIONS IN: molecular_function unknown; } \\
\text { INVOLVED IN: biological_process unknown; LOCATED IN: } \\
\text { endomembrane system; EXPRESSED IN: 15 plant structures; } \\
\text { EXPRESSED DURING: } 6 \text { growth stages; BEST Arabidopsis thaliana } \\
\text { protein match is: unknown protein (TAIR:AT1G07175.1); Has } 14 \text { Blast } \\
\text { hits to } 14 \text { proteins in } 3 \text { species: Archae - 0; Bacteria - 0; Metazoa - 0; } \\
\text { Fungi - 0; Plants - 14; Viruses - 0; Other Eukaryotes - 0 (source: NCBI } \\
\text { BLink). | chr2:12796907-12799419 REVERSE LENGTH=522 }\end{array}$ & -1.03 & -0.63 \\
\hline AT3G27110 & $\begin{array}{l}\text { Peptidase family M48 family protein | chr3:9997895-10000230 } \\
\text { FORWARD LENGTH }=1395\end{array}$ & -1.01 & -0.59 \\
\hline AT2G34930 & $\begin{array}{c}\text { disease resistance family protein / LRR family protein I } \\
\text { chr2:14737066-14739904 REVERSE LENGTH=2839 }\end{array}$ & -1.01 & -0.66 \\
\hline AT5G49830 & $\begin{array}{ccccc}\text { EXO84B I exocyst complex component } & 84 \mathrm{~B} & \text { | } \\
\text { chr5:20250486-20255039 REVERSE LENGTH=3035 } & & \end{array}$ & -1.01 & -1.05 \\
\hline AT5G25770 & $\begin{array}{ccc}\text { alpha/beta-Hydrolases } & \text { superfamily } & \text { protein } \\
\text { chr5:8969215-8972125 REVERSE LENGTH=1597 } & \\
\end{array}$ & -1.00 & -0.82 \\
\hline AT2G22860 & $\begin{array}{cccc}\text { ATPSK2, } & \text { PSK2 I phytosulfokine } 2 & \text { precursor } \\
\text { chr2:9737607-9738298 FORWARD LENGTH }=544\end{array}$ & -1.00 & -0.81 \\
\hline AT2G29450 & $\begin{array}{l}\text { ATGSTU5, ATGSTU1, AT103-1A, GSTU5 | glutathione S-transferase } \\
\text { tau } 5 \text { | chr2:12624586-12625637 REVERSE LENGTH=934 }\end{array}$ & -0.99 & -0.99 \\
\hline AT1G35910 & $\begin{array}{c}\text { TPPD | Haloacid dehalogenase-like hydrolase (HAD) superfamily } \\
\text { protein | chr1:13363003-13365060 REVERSE LENGTH=1402 }\end{array}$ & -0.98 & $\begin{array}{l}-0.78 \\
\end{array}$ \\
\hline AT1G53160 & \begin{tabular}{c|cccc} 
SPL4 I squamosa promoter binding protein-like & 4 & | \\
chr1:19806421-19807301 FORWARD LENGTH $=803$ & &
\end{tabular} & -0.98 & -0.51 \\
\hline AT1G21050 & $\begin{array}{l}\text { Protein of unknown function, DUF617 | chr1:7366775-7367678 } \\
\text { FORWARD LENGTH=904 }\end{array}$ & -0.98 & -0.84 \\
\hline AT5G20250 & $\begin{array}{l}\text { DIN10 | Raffinose synthase family protein | chr5:6833659-6836782 } \\
\text { FORWARD LENGTH=2753 }\end{array}$ & -0.98 & -0.60 \\
\hline AT1G33055 & $\begin{array}{l}\text { unknown protein; FUNCTIONS IN: molecular_function unknown; } \\
\text { INVOLVED IN: anaerobic respiration; LOCATED IN: endomembrane } \\
\text { system; EXPRESSED IN: } 13 \text { plant structures; EXPRESSED DURING: } 6 \\
\text { growth stages; Has } 20 \text { Blast hits to } 20 \text { proteins in } 8 \text { species: Archae - } \\
\text { 0; Bacteria - 0; Metazoa - 0; Fungi - 0; Plants - 20; Viruses - 0; Other } \\
\text { Eukaryotes - } 0 \text { (source: NCBI BLink). I chr1:11971308-11972578 } \\
\text { REVERSE LENGTH=1271 }\end{array}$ & -0.97 & -0.64 \\
\hline AT1G07175 & $\begin{array}{l}\text { unknown protein; FUNCTIONS IN: molecular_function unknown; } \\
\text { INVOLVED IN: biological_process unknown; LOCATED IN: } \\
\text { endomembrane system; BEST Arabidopsis thaliana protein match is: } \\
\text { unknown protein (TAIR:AT2G29995.1); Has } 30201 \text { Blast hits to } 17322 \\
\text { proteins in } 780 \text { species: Archae - 12; Bacteria - 1396; Metazoa - } \\
\text { 17338; Fungi - 3422; Plants - 5037; Viruses - 0; Other Eukaryotes - } \\
\text { 2996 (source: NCBI BLink). I chr1:2202330-2202774 FORWARD } \\
\text { LENGTH=268 }\end{array}$ & -0.97 & -1.09 \\
\hline AT4G02550 & 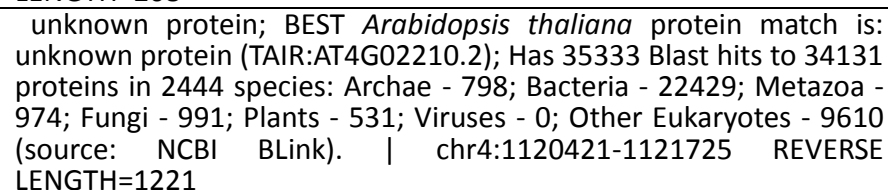 & -0.97 & -0.66 \\
\hline AT3G14850 & \begin{tabular}{c|cc} 
TBL41 I TRICHOME & BIREFRINGENCE-LIKE \\
chr3:4996448-4997693 FORWARD LENGTH=988
\end{tabular} & -0.96 & -0.80 \\
\hline
\end{tabular}




\begin{tabular}{|c|c|c|c|}
\hline Identifier & Description & $\begin{array}{l}\text { ColLL-tgaLL } \\
\text { logFC }\end{array}$ & $\begin{array}{l}\text { CoILL-ROXYLL } \\
\text { logFC } \\
\end{array}$ \\
\hline AT4G24120 & $\begin{array}{l}\text { YSL1, ATYSL1 | YELLOW STRIPE like } 1 \text { | chr4:12524491-12527341 } \\
\text { FORWARD LENGTH=2430 }\end{array}$ & -0.95 & -0.61 \\
\hline AT1G61610 & $\begin{array}{cccccc}\text { S-locus lectin } & \text { protein } & \text { kinase } & \text { family } & \text { protein } & \text { I } \\
\text { chr1:22733472-22736509 FORWARD LENGTH=2529 } & & \\
\end{array}$ & -0.95 & -0.95 \\
\hline AT2G21500 & $\begin{array}{l}\text { RING/U-box superfamily protein | chr2:9207549-9210231 REVERSE } \\
\text { LENGTH=1817 }\end{array}$ & -0.95 & -0.92 \\
\hline AT1G45145 & $\begin{array}{ccccccc}\text { ATTRX5, ATH5, LIV1, TRX5 I thioredoxin } & \text { H-type } & 5 & \text { I } \\
\text { chr1:17074942-17076330 REVERSE LENGTH=753 } & & & & \\
\end{array}$ & -0.94 & -0.89 \\
\hline AT5G05440 & 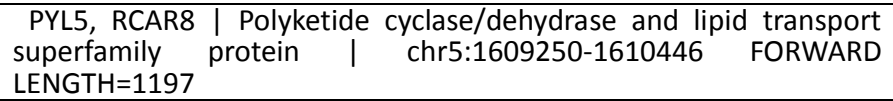 & -0.93 & -0.71 \\
\hline AT4G18440 & $\begin{array}{c}\text { L-Aspartase-like family protein } \quad \text { chr4:10186131-10188909 } \\
\text { REVERSE LENGTH }=1942\end{array}$ & -0.93 & -0.95 \\
\hline AT5G60410 & $\begin{array}{l}\text { ATSIZ1, SIZ1 | DNA-binding protein with MIZ/SP-RING zinc finger, } \\
\text { PHD-finger and SAP domain | chr5:24294890-24301091 FORWARD } \\
\text { LENGTH }=3154\end{array}$ & -0.93 & -0.74 \\
\hline AT2G06050 & $\begin{array}{l}\text { OPR3 I oxophytodienoate-reductase } 3 \text { | chr2:2359240-2362118 } \\
\text { REVERSE LENGTH=1233 }\end{array}$ & -0.93 & -0.96 \\
\hline AT1G03090 & $\begin{array}{l}\text { MCCA I methylcrotonyl-CoA carboxylase alpha chain, } \\
\text { mitochondrial / 3-methylcrotonyl-CoA carboxylase } 1 \text { (MCCA) | } \\
\text { chr1:739679-744184 FORWARD LENGTH=2606 }\end{array}$ & -0.93 & -0.70 \\
\hline AT5G65140 & $\begin{array}{l}\text { TPPJ | Haloacid dehalogenase-like hydrolase (HAD) superfamily } \\
\text { protein | chr5:26020410-26022222 REVERSE LENGTH=1124 }\end{array}$ & -0.92 & -0.81 \\
\hline AT5G56870 & $\begin{array}{l}\text { BGAL4 | beta-galactosidase } 4 \quad \mid \text { chr5:23004196-23008649 } \\
\text { FORWARD LENGTH=2502 }\end{array}$ & -0.92 & -0.65 \\
\hline AT3G10915 & $\begin{array}{c}\begin{array}{c}\text { Reticulon family } \\
\text { LENGTH }=1201\end{array} \\
\end{array}$ & -0.92 & -0.70 \\
\hline AT5G55100 & $\begin{array}{c}\text { SWAP (Suppressor-of-White-APricot)/surp domain-containing } \\
\text { protein | chr5:22361102-22364759 REVERSE LENGTH=2806 }\end{array}$ & -0.92 & -0.60 \\
\hline AT1G63530 & $\begin{array}{l}\text { BEST Arabidopsis thaliana protein match is: hydroxyproline-rich } \\
\text { glycoprotein family protein (TAIR:AT1G63540.1); Has } 10212 \text { Blast } \\
\text { hits to } 4024 \text { proteins in } 434 \text { species: Archae - 1; Bacteria - 1259; } \\
\text { Metazoa - 3608; Fungi - 2247; Plants - 291; Viruses - 90; Other } \\
\text { Eukaryotes - 2716 (source: NCBI BLink). | chr1:23563315-23565555 } \\
\text { FORWARD LENGTH=1925 }\end{array}$ & -0.92 & -0.79 \\
\hline AT3G21510 & \begin{tabular}{c|ccc|c} 
AHP1 I histidine-containing phosphotransmitter & 1 & I \\
chr3:7578175-7579599 REVERSE LENGTH=784 & & &
\end{tabular} & -0.91 & -0.84 \\
\hline AT3G17712 & $\begin{array}{l}\text { unknown protein; FUNCTIONS IN: molecular_function unknown; } \\
\text { INVOLVED IN: biological_process unknown; LOCATED IN: } \\
\text { cellular_component unknown; CONTAINS InterPro DOMAIN/s: } \\
\text { Protein of unknown function DUF1740 (InterPro:IPRO13633); BEST } \\
\text { Arabidopsis thaliana protein match is: unknown protein } \\
\text { (TAIR:AT3G17740.1). I chr3:6056870-6060287 FORWARD } \\
\text { LENGTH=2653 }\end{array}$ & -0.91 & -0.61 \\
\hline AT1G11925 & $\begin{array}{c}\text { Stigma-specific Stig1 family protein } \mid \text { chr1:4025930-4026732 } \\
\text { REVERSE LENGTH=803 }\end{array}$ & -0.91 & -1.09 \\
\hline AT2G19800 & $\begin{array}{c}\text { MIOX2 | myo-inositol oxygenase } 2 \quad \mid \text { chr2:8530896-8533508 } \\
\text { REVERSE LENGTH=1318 }\end{array}$ & -0.90 & -0.90 \\
\hline AT5G17650 & $\begin{array}{l}\text { glycine/proline-rich protein | chr5:5816698-5818347 REVERSE } \\
\text { LENGTH=993 }\end{array}$ & -0.90 & -0.71 \\
\hline AT3G48390 & $\begin{array}{l}\text { MA3 domain-containing protein } \quad \text { chr3:17920815-17923496 } \\
\text { FORWARD LENGTH=2344 }\end{array}$ & -0.90 & -0.92 \\
\hline AT1G19230 & $\begin{array}{ccclc}\begin{array}{c}\text { Riboflavin } \\
\text { chr1:6644189-6649375ase-like }\end{array} & \text { superfamily } & \text { protein } & \text { I } \\
\end{array}$ & -0.90 & -0.54 \\
\hline AT3G47490 & $\begin{array}{llll}\begin{array}{l}\text { HNH } \\
\text { LENGTH }=965\end{array} & \text { chroclease } & \text { chr3:17498337-17499301 } & \text { FORWARD } \\
\end{array}$ & -0.89 & -1.05 \\
\hline AT3G22640 & $\begin{array}{l}\text { PAP85 | cupin family protein | chr3:8011724-8013902 REVERSE } \\
\text { LENGTH }=1658\end{array}$ & -0.89 & -0.77 \\
\hline AT5G49520 & \begin{tabular}{cc|cccc} 
WRKY48, & ATWRKY48 & WRKY & DNA-binding & protein & 48 \\
chr5:20090776-20093346 FORWARD LENGTH=1793
\end{tabular} & -0.89 & -0.48 \\
\hline AT1G21140 & $\begin{array}{cccccc}\text { Vacuolar iron } & \text { transporter } & \text { (VIT) } & \text { family } & \text { protein } & \text { I } \\
\text { chr1:7404383-7405281 FORWARD LENGTH=899 } & & & \\
\end{array}$ & -0.89 & -0.82 \\
\hline AT2G07680 & $\begin{array}{c}\text { ATMRP11, MRP11, ABCC13 | } \text { multidrug resistance-associated } \\
\text { protein } 11 \mid \text { chr2:3514745-3522491 FORWARD LENGTH=4244 }\end{array}$ & -0.89 & -0.85 \\
\hline AT4G08300 & $\begin{array}{ccccc}\text { nodulin MtN21 } & \text { /EamA-like transporter family protein } \\
\text { chr4:5244891-5248342 FORWARD LENGTH=1444 } & & \\
\end{array}$ & -0.89 & -0.97 \\
\hline AT4G27450 & $\begin{array}{c}\text { Aluminium induced protein with YGL and LRDR motifs I } \\
\text { chr4:13727484-13728886 REVERSE LENGTH=1137 }\end{array}$ & -0.89 & -1.00 \\
\hline AT1G65120 & $\begin{array}{cccc}\begin{array}{l}\text { Ubiquitin carboxyl-terminal } \\
\text { chr1:24191348-24196073 REVERSE LENGTH }=3719\end{array} & & \\
\end{array}$ & -0.89 & -0.57 \\
\hline AT1G64500 & $\begin{array}{l}\text { Glutaredoxin family protein | chr1:23953233-23954492 FORWARD } \\
\text { LENGTH=1260 }\end{array}$ & -0.88 & -0.53 \\
\hline
\end{tabular}




\begin{tabular}{|c|c|c|c|}
\hline Identifier & Description & $\begin{array}{l}\text { ColLL-tgaLL } \\
\text { logFC }\end{array}$ & $\begin{array}{l}\text { CoILL-ROXYLL } \\
\quad \operatorname{logFC}\end{array}$ \\
\hline AT1G61120 & \begin{tabular}{ccc|ccc|} 
TPS04, GES, TPS4 & terpene & synthase & 04 & I \\
chr1:22523637-22528811 FORWARD LENGTH=2899 & &
\end{tabular} & -0.88 & -0.67 \\
\hline AT5G56100 & $\begin{array}{l}\text { glycine-rich protein / oleosin l chr5:22717115-22717751 } \\
\text { FORWARD LENGTH=637 }\end{array}$ & -0.88 & -1.00 \\
\hline AT4G33770 & $\begin{array}{ccccc}\text { Inositol 1,3,4-trisphosphate } & \text { 5/6-kinase } & \text { family } & \text { protein } \\
\text { chr4:16193422-16195357 REVERSE LENGTH=1183 } & & \\
\end{array}$ & -0.87 & -0.70 \\
\hline AT3G26816 & $\begin{array}{l}\text { MIR169L | MIR169L; miRNA | chr3:9875893-9876103 REVERSE } \\
\text { LENGTH=211 }\end{array}$ & -0.84 & -1.05 \\
\hline AT5G13220 & \begin{tabular}{cc|ccc|} 
JAZ10, TIFY9, JAS1 I jasmonate-zim-domain & protein & 10 & I \\
chr5:4218888-4220767 FORWARD LENGTH=1025 & & &
\end{tabular} & -0.84 & -0.69 \\
\hline AT2G41640 & $\begin{array}{l}\text { Glycosyltransferase family } 61 \text { protein | chr2:17360486-17363788 } \\
\text { FORWARD LENGTH=2496 }\end{array}$ & -0.84 & -0.60 \\
\hline AT5G18170 & $\begin{array}{l}\text { GDH1 | glutamate dehydrogenase } 1 \text { | chr5:6006039-6008472 } \\
\text { FORWARD LENGTH=1593 }\end{array}$ & -0.83 & -0.86 \\
\hline AT5G16370 & $\begin{array}{l}\text { AAE5 | acyl activating enzyme } 5 \text { | chr5:5356605-5358511 REVERSE } \\
\text { LENGTH=1907 }\end{array}$ & -0.82 & -0.88 \\
\hline AT4G39780 & 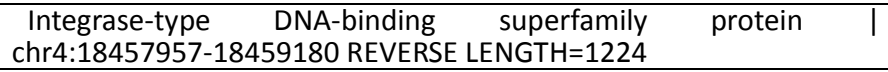 & -0.81 & -0.89 \\
\hline AT1G66783 & $\begin{array}{l}\text { MIR157A | MIR157A; miRNA | chr1:24913206-24913296 REVERSE } \\
\text { LENGTH=91 }\end{array}$ & -0.81 & -1.11 \\
\hline AT4G33770 & $\begin{array}{ccccc}\text { Inositol 1,3,4-trisphosphate } & \text { 5/6-kinase family } & \text { protein } & \text { I } \\
\text { chr4:16193422-16196428 REVERSE LENGTH=1529 } & & \\
\end{array}$ & -0.79 & -0.84 \\
\hline AT4G38470 & $\begin{array}{c}\text { ACT-like protein tyrosine kinase family protein } \\
\text { chr4:17999432-18003681 FORWARD LENGTH }=1858\end{array}$ & -0.79 & -0.65 \\
\hline AT1G12780 & $\begin{array}{l}\text { UGE1, ATUGE1 | UDP-D-glucose/UDP-D-galactose 4-epimerase } 1 \text { | } \\
\text { chr1:4355926-4358328 REVERSE LENGTH=1462 }\end{array}$ & -0.77 & -0.76 \\
\hline AT3G06125 & other RNA | chr3:1848883-1850596 FORWARD LENGTH=513 & -0.76 & -0.89 \\
\hline AT3G06125 & other RNA | chr3:1848848-1849332 FORWARD LENGTH=485 & -0.76 & -0.76 \\
\hline AT5G26200 & \begin{tabular}{ccccc|} 
Mitochondrial substrate carrier & family & protein & | \\
chr5:9157142-9158404 FORWARD LENGTH $=1263$ & & \\
\end{tabular} & -0.76 & -0.72 \\
\hline AT2G39570 & \begin{tabular}{cc|c} 
ACT domain-containing & protein & chr2:16507896-16510198 \\
FORWARD LENGTH $=1760$ & & \\
\end{tabular} & -0.75 & -0.59 \\
\hline AT3G01850 & $\begin{array}{l}\text { Aldolase-type TIM barrel family protein | chr3:299987-302038 } \\
\text { REVERSE LENGTH=1056 }\end{array}$ & -0.74 & -0.63 \\
\hline AT1G49130 & 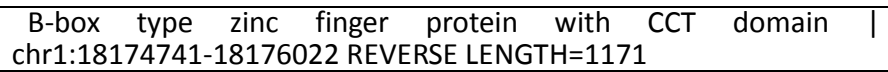 & -0.74 & -0.70 \\
\hline AT1G62480 & $\begin{array}{ccc}\text { Vacuolar } & \text { calcium-binding } & \text { protein-related } \\
\text { chr1:23128705-23129759 FORWARD LENGTH=764 } & \text { I } \\
\end{array}$ & -0.73 & -0.50 \\
\hline AT5G57655 & $\begin{array}{c}\text { xylose isomerase family protein } \\
\text { FORWARD LENGTH=1938 }\end{array}$ & -0.73 & -0.63 \\
\hline AT5G10030 & \begin{tabular}{cc|ccccc} 
TGA4, & OBF4 & TGACG & motif-binding & factor & 4 & I \\
chr5:3137323-3140252 REVERSE LENGTH=1675
\end{tabular} & -0.73 & -0.65 \\
\hline AT5G30490 & $\begin{array}{l}\text { CONTAINS InterPro DOMAIN/s: Craniofacial development protein } \\
\text { 1/Bucentaur (InterPro:IPRO11421); Has } 333 \text { Blast hits to } 324 \\
\text { proteins in 149 species: Archae - 0; Bacteria - 18; Metazoa - 117; } \\
\text { Fungi - 96; Plants - 49; Viruses - 0; Other Eukaryotes - } 53 \text { (source: } \\
\text { NCBI BLink). I chr5:11611983-11614530 FORWARD LENGTH=1050 }\end{array}$ & -0.72 & -0.55 \\
\hline
\end{tabular}




\section{Acknowledgements}

All the work was done in the Department of Plant Molecular Biology and Physiology, Georg-August-University. This is the last part of my thesis and I would like to say thanks to all the people who helped me during my study.

First and foremost, I would like to offer my sincere gratitude to my doctoral advisor Prof. Dr. Christiane Gatz for giving me the opportunity to work in her laboratory under her guidance. Her immense knowledge and criticism served as a resource to frequently promote this project. I would also like to thank for giving advice in countless revisions of this thesis.

I wish to express my sincere thanks to my thesis committee members: Prof. Ivo Feussner, Prof. Volker Lipka, PD Dr. Thomas Teichman, Dr. Marcel Wiermer and Dr. Martin Fulda for their constructive suggestion concerning my research. I would also like to acknowledge Dr. Corinna Thurow for helping to analyze the microarray data and offering valuable suggestions throughout the course of my research.

Especially, I would like to thank Dr. Martin Muthreich for initiating the research on clade I TGA factors and ROXY9 and Florian Jung for generating roxy9 CRISPR-Cas9 lines.

I am deeply grateful to Ronald Scholz, Anna Hermann, Katharina Dworak, and Larissa Kunz for their excellent technical support. I am also thankful to Dr. Guido Kriete for managing laboratory-related issues. I also greatly appreciate the help from all my past and current lab colleagues. Sina Barghahn, Jelena Budimir, Ronja Hacke, Dr. Nathannon Leelarasamee, Dr. Li-Jun Huang, Dr. Alexander Meier, Aswin Nair, Jan Oberdiek, Dr. Frederik Polzin, Dr. Neena Ratnakaran, Dr. Johanna Schmitz, Julia Schröder, Dr. Armin Töller, Katrin Treffon, PD Dr. Joachim Uhrig. I have really enjoyed working with them.

Last but not least, I would like to thank all of my friends in Goettingen. We have spent a wonderful time together. 


\section{Curriculum Vitae}

\section{Personal data:}
Name:
Ning Li
Date of Birth: $\quad 10.10 .1985$
Place of Birth: Zibo city, Shandong province, China
E-mail:
nli@gwdg.de

\section{Education:}

Ph.D. (Plant Molecular Biology), University of Goettingen, Germany 2012.10-present

M.Sc. (Environmental Biotechnology), Gyeongsang National University, Korea 2009.09-2012.08

B.Sc. (Biological Science), Northeast Forestry University, Harbin, China 2005.09-2009.07

\section{Research Projects}

- Plant-specific glutaredoxin ROXY9 regulates hyponastic growth by inhibiting TGA1 function. (2012- present)

- Characterization of GIGANTEA-mediated ABA signaling in Arabidopsis thaliana. (2011-2012)

- Arabidopsis Yucca6 plays as a thioredoxin reductase and reactive oxygen species scavenger. (2009-2011)

\section{Publications}

Huang LJ, Li N, Thurow C, Wirtz M, Hell R, and Gatz C (2016). Ectopically expressed glutaredoxin ROXY19 negatively regulates the detoxification pathway in Arabidopsis thaliana. BMC Plant Biology 16: 200.

Cha JY, Kim WY, Kang SB, Kim JI, Baek D, Jung IJ, Kim MR, Li N, Kim HJ, Nakajima M, Asami T, Sabir JS, Park HC, Lee SY, Bohnert HJ, Bressan RA, Pardo JM, Yun DJ (2015). A novel thiol-reductase activity of Arabidopsis YUC6 confers drought tolerance independently of auxin biosynthesis. Nature Communications 6: 8041-8054.

Kim WY, Ali Z, Park HJ, Park SJ, Cha JY, Perez-Hormaeche J, Quintero FJ, Shin G, Kim MR, Zhang Q, Li N, Park HC, Lee SY, Bressan RA, Pardo JM, Bohnert HJ, Yun DJ (2013). Release of SOS2 kinase from sequestration with GIGANTEA determines salt tolerance in Arabidopsis. Nature Communications 4: $1352-1364$. 